\title{
Management of water hyacinth \\ (Eichhornia crassipes [Mart.] Solms) \\ using bioagents in the Rift Valley of Ethiopia
}

Firehun Yirefu Gebregiorgis 


\section{Thesis committee}

\section{Promotor}

Prof. Dr P.C. Struik

Professor of Crop Physiology

Wageningen University \& Research

\section{Co-promotors}

Dr E.A. Lantinga

Associate professor, Farming Systems Ecology Group

Wageningen University \& Research

Dr Taye Tessema

Lecturer Plant Sciences

Ambo University, Ethiopia

\section{Other members}

Prof. Dr D. Kleijn, Wageningen University \& Research

Prof. Dr J.J.A. van Loon, Wageningen University \& Research

Dr G.E. van Halsema, Wageningen University \& Research

Dr C. Kempenaar, Wageningen University \& Research

This research was conducted under the auspices of the C.T. de Wit Graduate School for Production Ecology and Resource Conservation 


\title{
Management of water hyacinth (Eichhornia crassipes [Mart.] Solms) using bioagents in the Rift Valley of Ethiopia
}

\author{
Firehun Yirefu Gebregiorgis
}

\section{Thesis}

submitted in fulfilment of the requirements for the degree of doctor at Wageningen University by the authority of the Rector Magnificus,

Prof. Dr A.P.J. Mol,

in the presence of the

Thesis Committee appointed by the Academic Board

to be defended in public

on Friday 31 March 2017

at 1.30 p.m. in the Aula. 
Firehun Yirefu Gebregiorgis

Management of water hyacinth (Eichhornia crassipes [Mart.] Solms) using bioagents in the Rift Valley of Ethiopia,

174 pages.

$\mathrm{PhD}$ thesis, Wageningen University, Wageningen, the Netherlands (2017)

With references, with summary in English

ISBN 978-94-6343-056-2

DOI http://dx.doi.org/10.18174/401611 


\begin{abstract}
Firehun Yirefu Gebregiorgis (2017). Management of water hyacinth (Eichhornia crassipes [Mart.] Solms) using bioagents in the Rift Valley of Ethiopia. PhD Thesis, Wageningen University, The Netherlands.
\end{abstract}

This thesis presents a study on management of water hyacinth (Eichhornia crassipes [Mart.] Solms) using insects and fungal pathogens as bioagents. The main goal was to develop an effective biocontrol strategy for water hyacinth in the Rift Valley of Ethiopia. To this end, a field survey was conducted to assess the agro-ecological distribution of water hyacinth and of native fungal pathogens found in association with water hyacinth. We also performed laboratory and lath house experiments on (i) pathogenicity and host specificity of the fungal pathogens; (ii) adaptability, life table, efficacy and host specificity of the two Neochetina weevils; and (iii) the synergetic effects of integrated use of Neochetina weevils and fungal pathogen as bioagents. Survey results indicated that the weed is distributed in the Rift Valley water bodies located in low, mid and high altitude. The survey results also identified 25 fungal species found in association with water hyacinth that belonged to nine genera. Among the isolates, Alternaria alternata, A. tenuissima, and Alternaria spp. hold promise as possible bioagents of water hyacinth.

Laboratory study on life cycle and development of Neochetina weevils indicated the two weevils took shorter generation time in Ethiopia than in Argentina but relatively similar to Kenya and Uganda. In Ethiopia, the two weevils produced four generations per year indicating their successful establishment. Feeding by adult weevils and tunneling by larvae significantly impacted the vigour and reproduction of water hyacinth plants. A herbivory loads of three pairs of N. bruchi and two pairs of $N$. eichhorniae showed the highest level of leaf damage and defoliated petioles. The study also reinforced that the two weevils are sufficiently host-specific. Finally, a study on integrated use of Neochetina weevils and an indigenous plant pathogen revealed that the two Neochetina weevils and the fungus A. alternata were together able to reduce the vegetative growth and fresh weight of water hyacinth plants considerably.

This study recommends integrated use of fungal species and the two weevils to control water hyacinth. Implications of the findings are also discussed in the context of integrated water hyacinth management using the native fungal pathogens and the two weevils.

Keywords: Classical bioagent, Ethiopia, mycoherbicides, native bioagent, Neochetina weevils, water hyacinth 

This dissertation is dedicated to my beloved family 



\section{Contents}

Chapter 1 General introduction...........................................................................

Chapter 2 Water hyacinth in the Rift Valley water bodies of Ethiopia: Its distribution, socio-economic importance and management.....

Chapter 3 Joint use of insects and fungal pathogens in the management of water hyacinth (Eichhornia crassipes): Perspectives for Ethiopia......

Chapter 4 Occurrence and diversity of fungal pathogens associated with water hyacinth and their potential as biocontrol agents in the Rift Valley of Ethiopia

Chapter 5 Adaptability of two weevils (Neochetina bruchi and Neochetina eichhorniae) with potential to control water hyacinth in the Rift Valley of Ethiopia

Chapter 6 Pre-release evaluation of Neochetina weevils potential for the management of Eichhornia crassipes (Mart.) Solms in the Rift Valley of Ethiopia.

Chapter 7 Integrated control of water hyacinth with a fungal pathogen (Alternaria alternata [Fr.] Keissler) and Neochetina weevils in the Rift Valley of Ethiopia.

Chapter 8 General discussion.

References

Summary....

List of publications of the author................................ 167

Acknowledgements............................................ 171

Curriculum vitae................................................. 173

PE\&RC Training and Education Statement........................ 174 



\section{CHAPTER 1}

General introduction 


\subsection{Background and justification}

One of the major problems in water bodies of the tropics and sub-tropics is the floating aquatic weed water hyacinth (Eichhornia crassipes [Mart.] Solms), which originated from the Amazon Basin and has disseminated very quickly in many tropical and subtropical countries of Latin America and the Caribbean, Africa, Southeast Asia and the Pacific (Julien et al., 1999; Julien, 2001). This weed has been identified as one of the 100 most aggressive invasive species and recognized as one of the top ten worst weeds in the world (Patel, 2012). It is characterized by rapid growth rates, extensive dispersal capabilities, large and rapid reproductive output and broad environmental tolerance (Zhang et al., 2010). Water hyacinth forms dense impenetrable mats across the water surface, limiting access by man, animals and machinery. Navigation and fishing are obstructed, and irrigation as well as drainage systems become blocked (Julien et al., 1999). The economic impacts of the weed in seven African countries have been estimated at US\$20-50 million every year (UNEP, 2013).

In Ethiopia, this weed was officially first reported about 60 years ago in Koka Lake and the Awash River (Stroud, 1994). Water hyacinth infestation in Ethiopia has been manifested on a large scale in many water bodies of the country. The introduction and rapid spread of this weed in the Awash River Basin (Koka Lake, Koka Dam), Abbay River Basin (Lake Tana, Blue Nile), Baro-Akobo River Basin (Sobate, Baro, Gillo and Pibor rivers) and Rift Valley Basins System (Lake Ellen, Lake Abaya, Lake Elltoke), has created serious problems for the use of the water as a resource (Stroud, 1994; Rezene, 2005; Taye et al., 2009). The major problems include: hindrance to water transport, disrupting hydro-electric operations, blockage of canals and rivers, causing flooding and human health problem, increased evapotranspiration, interference with fishing, irrigation, navigation, livestock watering and reduction of biodiversity (Hailu et al., 2004; Kassahun et al. 2004; Senayit et al., 2004; Taye et al., 2009). Comprehensive local estimates of economic impacts of water hyacinth in the affected areas of the Ethiopian water bodies have not been done yet, except for the Wonji-Shoa Sugar estate which incurred about US\$ 100,000 in total from 2000 to 2013 for the control of this weed (Firehun et al., 2014).

For Ethiopia, which has an economy highly dependent on agriculture and high population growth, it is prudent to effectively manage its water resources. Moreover, since most of the rivers affected by water hyacinth in Ethiopia cross the country border and feed neighbouring countries, effective management of the local water resources would benefit livelihoods of riparian residents in the neighbouring countries. 
Methods to control and contain the weed in Ethiopia include manual as well as mechanical clearing and in some spots also chemical control. Use of herbicides, even though effective, is not popular in Ethiopia because of high costs and pollution problems (Dula et al., 2008; Taye et al., 2009). Therefore, the success of these methods of control has been rather limited. In contrast, successful biocontrol of water hyacinth is long lasting, cost efficient and safe (Julien et al., 1999). Besides, various reports indicate that the use of chemical and mechanical methods to control water hyacinth would provide only temporary relief, and for a sustainable, long-term solution it appears necessary to employ an integrated approach in which biological control agents play a key role (Shabana, 1997; Martinez and Charudattan, 1998; Charudattan, 2001a).

Use of biological agents for water hyacinth control includes arthropods and pathogens. Among the arthropods, the mite Orthogalumna terebrantis Wallwork, the moths Acigona infusella Walker and Sameodes albiguttalis (Warren), the miridae Eccritotarsus catarinensis Carvalho, and weevils (Neochetina eichhorniae Warner and N. bruchi Hustache) are generally considered as good candidates (Ogwang and Molo, 1997; Center et al., 1999a, b; Grodowitz et al., 2000; Moran, 2004; Williams et al., 2007). Among the pathogens, controlled experimental studies have confirmed that Acremonium zonatum, Alternaria eichhorniae, A. alternata, Bipolaris spp., Cercospora piaropi (Cercospora rodmanii), Drechslera hawaiiensis, Fusarium equiseti, F. pallidoroseum, Rhizoctonia solani, Myrothecium advena, Sclerotinia sclerotiorum, and Ulocladium atrum significantly reduce this weed's biomass (Conway and Cullen, 1978; Shabana et al., 1995b; Charudattan, 2001a; Naseema et al., 2001; Ochiel et al., 2001; Mohan et al., 2002; El-Morsy, 2004; Praveena and Naseema, 2004; Waipara et al., 2006).

Overall, numerous bioagents have been released for the control of water hyacinth. However, diverging level of success of these agents have been attained in different parts of the world. In Ethiopia, although water hyacinth is present for the last 60 years, its biocontrol using plant pathogens and insect pests has seldom been attempted, and if done it was mainly to identify potential biological agents. For instance, a survey carried out in the Gambella region (during the 1970s) confirmed prevalence of the fungus C. rodmanii with 5-15\% level of infestations (Stroud, 1994). Moreover, aphids were recorded. Another survey conducted in the Awash River showed aphid and mite infestations on water hyacinth (Stroud, 1994).

Despite the presence of highly virulent fungal pathogens and effective weevils against water hyacinth, none of them have been utilized to control this aquatic weed in Ethiopia up till now. Hence, an in-depth evaluation of the most potential bioagents in water hyacinth management in the country is crucial. 


\section{Chapter 1}

\subsection{Biology and ecology of water hyacinth}

Water hyacinth is a perennial, herbaceous and aquatic plant species of the family Pontederiaceae (Gopal, 1987). The genus Eichhornia contains a number of other species, all of which are aquatic, but only E. crassipes has become a serious weed (Coetzee et al., 2009b). The leaves of water hyacinth are comprised of smooth, glossy, circular to kidney-shaped lamina and a swollen, spongy petiole (Figure 1.1). The petiole contains air, causing plants to float on the water surface. Stolons grow horizontally to produce daughter plants from terminal buds. The bisexual flowers are bluish purple with a yellow centre and are produced on a single spike up to $60 \mathrm{~cm}$ in length (Julien et al., 1999). The flowers can be self-fertilized. The roots are long, fibrous and feather-like, and often dark-coloured (Wright and Purcell, 1995).

Water hyacinth shows substantial variation in both leaf and flower forms (Julien et al., 1999). The petiole varies from long and slender to swollen or bulbous. The shape of the petiole influences the amount of air contained and consequently the capacity for the plant to float (Julien et al., 2001). Wright and Purcell (1995) highlighted the relationship between the two petiole types and level of infestation. Accordingly, more slender petioles are typical of plants which occur within dense, crowded infestations, whereas more bulbous petioles characterize plants in open water or the open water margins of infestations. Flowers are of three distinct types, differing in the length of the styles and stamens (Harley, 1990; Wright and Purcell, 1995). Within the introduced range of the species, the intermediate length style form predominates, whilst the long-styled form occurs less frequently (Julien et al., 1999). The short-styled form is still restricted to South America.

The inflorescence bears between 8 and 15 violet and yellow flowers. Each inflorescence produces 3000-4500 seeds (Hill, 1999) and a single rosette can produce several inflorescences each year (Barrett, 1980). The seeds remain viable for 5-20 years (Gopal, 1987). Seeds sink following release from the seed capsule and may subsequently germinate as water levels change (Wright and Purcell, 1995). Water hyacinth seeds germinate in backwater areas, in ditches and channels, and in other moist habitats. The seedlings develop into plants with their own leaves and root systems within 40 days after germination (Barrett, 1980).

After some time, the plants get detached from the mud and become free floating and then they multiply vegetatively and form floating mats (Rao, 1988).

Vegetative reproduction is a common form of propagation and is largely responsible for the rapid increase and spread of water hyacinth into new areas (Barrett, 1980). The daughter plants produced from the horizontal stolons develop their own roots and later on separate from the mother plant. These plants are readily distributed by currents, 


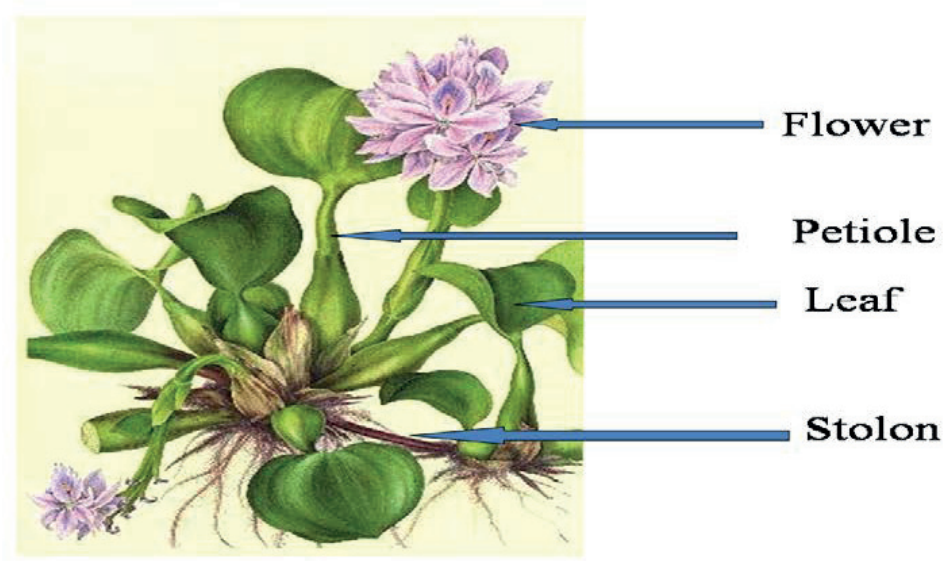

Figure 1.1. Morphology of water hyacinth.

winds, fishing nets and water craft (Julien et al., 1999). This weed has also been spread through dispersal of seeds. As the seeds are released directly into the water (Barrett, 1980), they can also be easily transported by vehicles, boats or pedestrians passing through infested areas (Julien et al., 2001). On the other hand, where the plant produces seeds, these may cause a new outbreak of water hyacinth even after a certain site is completely cleared of an initial infestation (Gopal, 1987).

A rapid vegetative growth through off-sets is the main secret of a quick build-up of water hyacinth into blankets of dense, tough mats. Holm et al. (1991) reported that two parent plants were surrounded by 300 off-springs within 23 days and even 1200 after four months. The floating mats of water hyacinth are often strong enough to allow to walk over them, and to stop boats and ships.

Optimum growth of water hyacinth occurs in still or slow moving fresh water under conditions of high relative humidity, long sun exposure, water temperature of 28-30 ${ }^{\circ} \mathrm{C}$, and an abundant availability of nitrogen, phosphorous and potassium (Reddy et al., 1991). Plants can, however, tolerate a wide range of growth conditions and weather extremes. The plants can also withstand frost, although prolonged cold weather may kill them while the seeds remain viable (Wright and Purcell, 1995).

Moreover, the plant is very able to adapt to varying circumstances. In most cases, the water hyacinth is often associated with other water weeds such as Pistia stratiotes, Myriophyllum aquaticum and Azolla filiculoides (Julien et al., 1999). However, unless some form of control measure has been implemented, it tends to be the dominant species. Besides, the weed mats deplete dissolved oxygen of the water and consequently fish and phytoplankton are unable to survive (Lindsey and Hirt, 1999). 


\section{Chapter 1}

\subsection{Water hyacinth occurrence and distribution}

Water hyacinth is found across the tropical and sub-tropical regions (Figure 1.2). Originally from the Amazon Basin, its entry into Africa, Asia, Australia, and North America was facilitated by human activities (Dagno et al., 2012). Since the end of nineteenth century, water hyacinth plants have been taken from its origin to all parts of the world as an ornamental and botanical gardens plant (CABI, 2015). But things got out of control: the water hyacinth was like a tiger let out of its cage (Tegene and Ayele, 2014). Later, water hyacinth has found its way into rivers, lakes, dams, reservoirs, irrigation and drainage structures throughout the tropics and the sub-tropics and became an invasive weed (CABI, 2015).

Julien et al. (1999) indicated that in the USA the weed was first introduced in Louisiana in 1884 and afterwards in Florida in 1890. Because of its striking flowers, it was deliberately introduced into botanic gardens in many other countries, from which it inevitably spread as a weed (CABI, 2015). Important explanations for the continental spread of the weed include its capacity to quickly multiply when away from its natural enemies in South America (Rezene, 2005).

Water hyacinth occurs in almost all of the wetlands of Africa and poses serious social, economical and environmental problems for millions of people in riparian

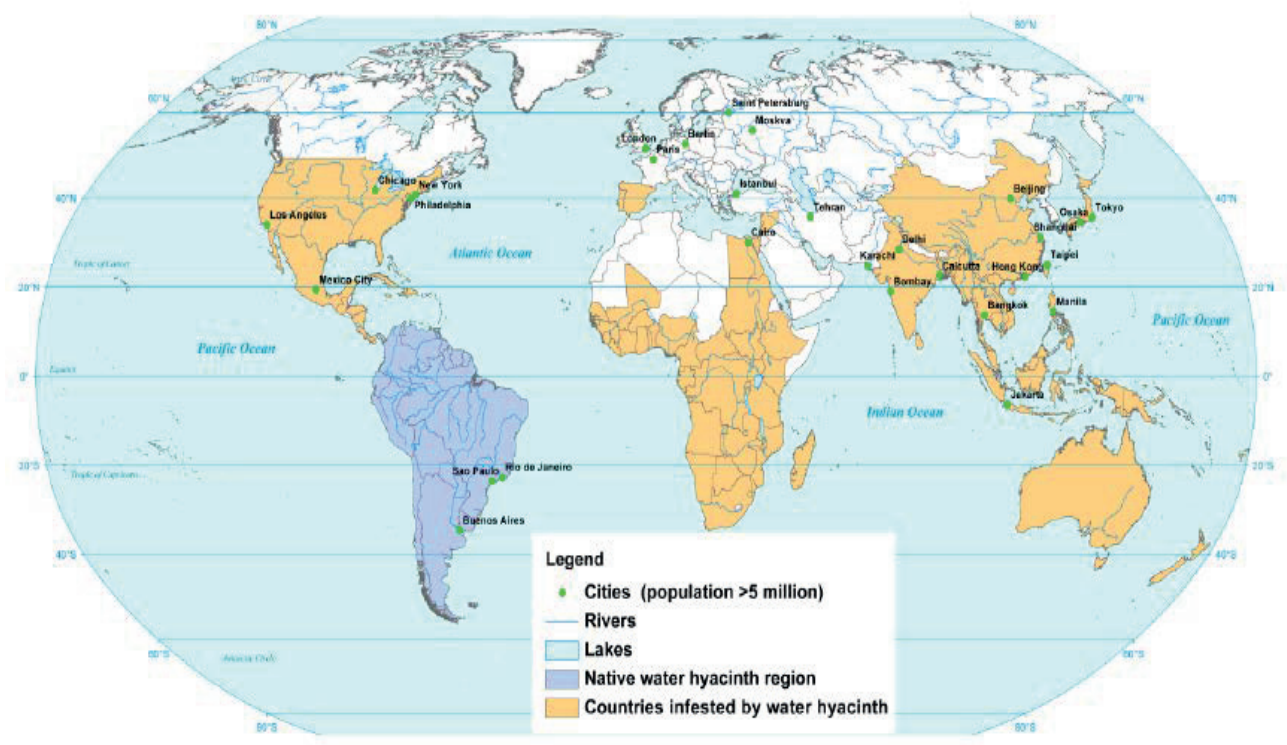

Figure 1.2. Worldwide distribution of water hyacinth (adapted from UNEP, 2013). 
communities and, therefore, added constraints on development of the nation (Howard and Matindi, 2003). Water hyacinth occurs in almost all of the wetlands of Africa. The current distribution status of the weed in Africa is shown in Table 1.1.

In Europe, water hyacinth is established in the Azores (France) and in Corsica (Italy), and casual records are known from Belgium, the Czech Republic, Hungary, the Netherlands and Romania (EEA, 2012). DellaGreca et al. (2009) indicated that water hyacinth is a threat in Spain and Portugal. Water hyacinth used to be a popular water plant widely sold in home garden shops. However, recently, water hyacinth has been put on the European Union list of invasive species and is no longer allowed to be sold or imported.

In Asia, water hyacinth is widespread on freshwater wetlands of the Mekong Delta, especially in standing water (MWBP/RSCP, 2006). Biswas et al. (2007) reported that water hyacinth has been detected in the Sundarbans mangrove forest of Bangladesh and has caused heavy siltation in the wetlands of the Kaziranga National Park, India. As in many other countries, water hyacinth has caused many economic, social and environmental problems in southern China (Choo et al., 2006).

\subsection{Impact of the weed}

Water hyacinth poses serious socio-economic and environmental problems for millions of people in riparian communities and is, therefore, an added constraint on development (Howard and Matindi, 2003).

\subsubsection{Social impact}

The issue of water is the issue of life. In Africa, India and Sir Lanka, water hyacinth interferes with agricultural practices by blocking irrigation and drainage systems and by increasing the loss of water (Aweke, 1994). Societies that are able to use their water resources in an efficient and sustainable manner have succeeded in being food selfsufficient, reducing the incidence of water-borne diseases and minimizing adverse effects of the resource. The stagnant water resulted from obstructing effect of the weed provides a breeding ground and a habitat for several vectors of diseases such as mosquitoes, flies, snails and other organisms associated with human illnesses, including malaria, schistosomiasis, encephalitis, filariasis and cholera (CABI, 2015). These impacts pose, especially in the least developed countries, an additional burden on the limited health services and facilities available to the rural communities. In Ethiopia, Senayit et al. (2004) reported an increase in malaria incidence and lack of drinking water, whereas during peak infestation periods the floating weed serves as a host for snakes and crocodiles. 


\section{Chapter 1}

Table 1.1. Water hyacinth distribution in Africa (adapted from CABI, 2015).

\begin{tabular}{|c|c|c|}
\hline Country & Distribution status & References \\
\hline Angola & Restricted distribution & Gopal, 1987 \\
\hline Benin & Restricted distribution & EPPO, 2014; van Thielen, 1993 \\
\hline Botswana & Present & Gopal, 1987 \\
\hline Burkina Faso & Present & ЕРPO, 2014 \\
\hline Burundi & Present & Moorhouse et al., 2001; EPPO, 2014 \\
\hline Cameroon & Present & EPPO, 2014 \\
\hline Central African Republic & Restricted distribution & Gopal, 1987 \\
\hline Congo & Widespread & Gopal, 1987; EPPO, 2014 \\
\hline Congo Democratic Republic & Widespread & Gopal, 1987; EPPO, 2014 \\
\hline Côte d'Ivoire & Restricted distribution & Harley, 1993; ЕРPO, 2014 \\
\hline Egypt & Widespread & Fayad et al., 2001; EPPO, 2014 \\
\hline Equatorial Guinea & Present & EPPO, 2014 \\
\hline Ethiopia & Restricted distribution & Gopal, 1987; EPPO, 2014 \\
\hline Gabon & Present & EPPO, 2014 \\
\hline Ghana & Restricted distribution & EPPO, 2014; de Graft-Johnson, 1993 \\
\hline Guinea & Present & ЕРPO, 2014 \\
\hline Guinea-Bissau & Present & EPPO, 2014 \\
\hline Kenya & Widespread & Owiti, 1990; Mailu, 2001; IPPC-Secretariat, \\
\hline Liberia & Present & EPPO, 2014 \\
\hline Madagascar & Widespread & Binggeli, 2003; EPPO, 2014 \\
\hline Malawi & Widespread & Harley, 1993; Phiri et al., 2001; EPPO, 2014 \\
\hline Mali & Restricted distribution & Lomer, 1995 \\
\hline Mauritius & Present & Gopal, 1987; EPPO, 2014 \\
\hline Morocco & Present & EPPO, 2014 \\
\hline Mozambique & Restricted distribution & Gopal, 1987; EPPO, 2014 \\
\hline Niger & Restricted distribution & Akinyemiju, 1987; Lomer, 1995 \\
\hline Nigeria & Restricted distribution & Akinyemiju, 1987; EPPO, 2014 \\
\hline Réunion & Present & Gopal, 1987; EPPO, 2014 \\
\hline Rodriguez Island & Present & Royal Botanic Gardens Kew, 2012 \\
\hline Rwanda & Widespread & Harley, 1993; ЕРPO, 2014 \\
\hline Senegal & Restricted distribution & Gopal, 1987; EPPO, 2014 \\
\hline Seychelles & Present & Royal Botanic Gardens Kew, 2012 \\
\hline Sierra Leone & Present & ЕРPO, 2014 \\
\hline South Africa & Widespread & Jones, 2001; EPPO, 2014 \\
\hline Sudan & Widespread & Gay, 1960; Gopal, 1987; EPPO, 2014 \\
\hline Swaziland & Present & EPPO, 2014 \\
\hline Tanzania & Widespread & Mallya et al., 2001; EPPO, 2014 \\
\hline Zanzibar & Restricted distribution & Gopal, 1987 \\
\hline Togo & Present & EPPO, 2014 \\
\hline Uganda & Widespread & Mailu, 2001; Hill, 1999; EPPO, 2014 \\
\hline Zambia & Widespread & Bennett, 1972; Hill, 1997; EPPO, 2014 \\
\hline Zimbabwe & Widespread & Chikwenhere, 2001; EPPO, 2014 \\
\hline
\end{tabular}


Water hyacinth infestations have been reported to lower quantity of water supplied in Kenya and Tanzania (Mailu, 2001). Water hyacinth interferes with the water intake points through blockage, which consequently lowers the quantity of water pumped. Moreover, when the water level decreases, the unpleasant smell from decomposed water hyacinth residues disturbs the villagers. Water hyacinth also impedes the recreational use of rivers and lakes (Mujingni, 2012).

\subsubsection{Economic impact}

Julien et al. (1999) reported that access to harbors and docking areas can be seriously hindered by mats of water hyacinth. Canals and freshwater rivers can become impossible to use as they clog up with densely intertwined carpets of the weed. Hill (1999) reported that the effect is most acute for small-scale fishing communities: it may restrict their access to fishing grounds or interfere with the spreading or retrieval of nets or with landing their catch. This was especially serious on Lake Victoria. In Lake Victoria, fish catch rates on the Kenyan section decreased by $45 \%$ because water hyacinth mats blocked access to fishing grounds, delayed access to markets and increased costs (effort and materials) of fishing (Kateregga and Sterner, 2007). Similarly, in Lake Naivasha, the water hyacinth infestation has been observed to have a negative impact on the economic status of the fisher community (Waithaka, 2013).

Many large hydropower schemes are suffering from the effects of water hyacinth. For example, the Owen Falls hydropower scheme at Jinja on Lake Victoria, the Kariba dam which straddles the Zambia-Zimbabwe border on the Zambezi River, and Koka hydropower dam in Ethiopia suffer from the rapid reproduction rates of water hyacinth (Navarro and Phiri, 2000; Mailu, 2001; Senayit et al., 2004).

Dense infestations of water hyacinth restrict water flows in rivers and irrigation channels, interfere with irrigation equipment and have been known to cause structural damage to bridges (Jones, 2009). Reduced irrigation flow can indirectly cause loss on field crops but there can also be direct loss on paddy crops by suppressing the crop, inhibiting germination and interfering with harvesting (EEA, 2012; Patel, 2012). In Ethiopia, water hyacinth caused wastage of water through excessive evapotranspiration that would otherwise be used for sugarcane production (Firehun et al., 2007). Besides, the drainage system blockage by the weed contributes for the rise of groundwater table and flooding problems.

\subsubsection{Environmental impact}

Water hyacinth mats block canals and rivers leading to flooding. This effect is more aggravated on riparian residents with little capacity to protect themselves from the flood as well as flood associated impacts. It has been estimated that the flow of water 


\section{Chapter 1}

in the Nile could be reduced by up to one-tenth due to increased losses in Lake Victoria from water hyacinth (Julien et al., 1999). This reduction in flow could easily cause problems for adequate supply of water to irrigation schemes and for transport over water. For example, in Kenya, boats with capacities less than 700 tonnes cannot operate where there is heavy water hyacinth infestation (Mailu, 2001). As a result, in 1997, the Kenya Railways activities have been closed in Asembo, Homa Bay, Kendu Bay, Kowor, Mbita and Mfangano pier.

Once it proliferates in a water body, water hyacinth dramatically alters the ecosystem and this often results in environmental degradation and a reduction in biodiversity. A number of authors noted that in many water bodies and wetland areas, the encroachment of water hyacinth has reduced or eliminated natural vegetation (e.g., Terry, 1996; Kumar and Rohatgi, 1999). The plant may negatively impact some native species of invertebrates, fish, birds and plants. For example, in Madagascar, many parts of the Alaotra Lake, a site of biological importance, have been reported as covered with carpets of water hyacinth that are detrimental to a number of animal species, such as the duck Thalassornis leuconotus (Binggeli, 2003). Recent study in Lake Naivasha showed a massive reduction in fish population due to reduced oxygen levels, which was attributed from resurgence of water hyacinth (Waithaka, 2013).

The blockage of waterways by water hyacinth increases siltation and hinders activities like swimming, fishing and sand extraction (Mujingni, 2012). A summary of water hyacinth impacts is shown in Table 1.2.

\subsection{Management of water hyacinth}

Experiences worldwide indicate that different control measures have been employed for the management of this weed. This includes widely adopted conventional methods such as cutting and burning, physical removal, mechanical removal, use of herbicides (2,4-D, glyphosate), and biological agents (Harley and Forno, 1992; Center et al., 1999b; Julien et al., 1999; Malik, 2007). However, because of the rapid growth habit of the weed, the practical constraints and financial costs associated with physical, mechanical and herbicidal control, such control measures alone are not effective against water hyacinth.

Increasing concern about the financial and environmental costs associated with herbicidal control measures and their limited effectiveness has led to a growing interest in the use of biological control (Julien et al., 2001). Biological control of water hyacinth using natural enemies is the most economical and sustainable method of control as the control persists with little ongoing cost and no negative environmental impact (Julien et al., 1996). Insects and pathogens are known to have a controlling 
Table 1.2. Summary of social, economical and environmental impact of water hyacinth.

Water hyacinth impact

\section{Category}

Social Econom. Environm.

Interference with irrigation and drainage system

$+$

$+$

Increase in disease outbreaks (malaria, schistosomiasis, filariasis, cholera, etc)

Less access to water points (domestic and livestock use)

Lack of clean water

Increase in incidence of snake and crocodile bite

Disappearance of the aesthetic value of water bodies

Less access to harbours and docking

Reduced fish catches

Difficulties in electricity generation

Difficulties in water transportation

Difficulties in water extraction and purification

Decline in diversity and abundance of aquatic life

Effects on tourism

Decline in water quality

Increased water loss

Increased siltation

Increased potential for flooding

effect on water hyacinth. Research into the biological control of water hyacinth was initiated by the United States Department of Agriculture in 1961, and to date seven arthropods that attack water hyacinth in its region of origin have been released for biocontrol in a number of countries (Tipping et al., 2014). While there exists several native enemies of water hyacinth, two South American weevil beetles (N. eichhorniae and $N$. bruchi) and two water hyacinth moth species (Niphograpta albiguttalis and Xubida infusella) have had effective long-term control of water hyacinth in many countries, notably at Lake Chivero (Zimbabwe), Lake Victoria (Kenya and Uganda), Louisiana (USA), Mexico, Papua New Guinea and Benin (Williams et al., 2007; Gichuki et al., 2012; Dagno et al., 2012; Venter et al., 2013).

Moreover, several highly virulent pathogens of water hyacinth have been studied as promising candidates for biocontrol (Firehun et al., 2013). Details of the use of insects and pathogens as bioagents of water hyacinth are presented in the sections below. 


\section{Chapter 1}

\subsubsection{Use of insects as bioagents of water hyacinth}

Almost $50 \%$ of the 43 arthropod species found in association with water hyacinth have been identified as potential control agents because of the damage they cause or because of their narrow host range (Perkins, 1974). Although so many species have been identified, only a few have been released for control of the weed based on their adaptability, efficacy and host specificity. Cordo (1999) and Center et al. (2002) have listed these species according to their priorities for biological control. Accordingly, the arthropods were categorized into three priority groups.

The first priority group includes agents already in use worldwide, such as $N$. eichhorniae, N. bruchi, N. albiguttalis, and O. terebrantis. The second priority group includes candidates recently released or under testing: Eccritotarsus catarinensis, Xubida infusellus, Cornops aquaticum, Bellura densa, Paracles tenuis, and Thrypticus spp. The third priority group includes candidates that are poorly known or of questionable specificity (mostly with no recorded common names): a bombardier beetle [Brachinus Weber spp. (Coleoptera: Carabidae)], a water hyacinth moth [Argyractis subornata Hampson (Lepidoptera: Pyralidae)], a root-feeding rice pest [Macrocephala acuminata Dallas (Heteroptera: Pentatomidae)], a planthopper [Taosa inexacta Walker (Homoptera: Dictyopharidae)], two Argentinian species of planthoppers [Megamelus electrae Muir and M. scutellaris Berg (Homoptera: Delphacidae)], a stem miner [Eugaurax setigena Sabrosky (Diptera: Chloropidae)], a petiole-mining midge [Chironomus falvipilus Rempel (Diptera: Chironomidae)], a shore fly [Hydrellia sp. Robineau-Desvoidy (Diptera: Ephydridae)], and a mite [Flechtmannia eichhorniae Keifer (Acarina: Eriophyidae)]. The biology, host specificity, and potential for the management of water hyacinth by M. scutellaris have recently been better understood (Sosa et al., 2004, 2005, 2007a, b; Tipping et al., 2010). In addition, those findings indicated that $M$. scutellaris was highly specific to water hyacinth and caused 70\% biomass and 73\% leaf reduction (Tipping et al., 2010). Recently, M. scutellaris has been released in Florida and California (Tipping et al., 2014; Moran et al., 2016). Hence, this bioagent would now be better categorized as belonging to the second priority group. Table 3.1 of this thesis lists potential insects being used or recently released for the management of water hyacinth and their types of damage.

\subsubsection{Use of pathogens as bioagents of water hyacinth}

Biological control of weeds using plant pathogens has gained acceptance as a practical, safe, and environmentally beneficial weed management tool (Charudattan, 2001a). Use of plant pathogens has been shown to be highly effective against water hyacinth under experimental conditions (Shabana, 1997; Shabana et al., 1997). The 
fungal pathogen $C$. piaropi Tharp. has been studied extensively (Freeman and Charudattan, 1984; Charudattan et al., 1985) and was patented by the University of Florida (Conway et al., 1978). It has been released in South Africa as the classical biocontrol agent for water hyacinth (Morris et al., 1999). Worldwide, several efforts have been made to assess pathogens found in association with water hyacinth, and some of them which have been evaluated are in use either as classical or inundative biological control agents (Charudattan, 2001a).

In Florida, during a 1973 survey, 30 species of fungi were found in association with water hyacinth (Conway et al., 1974). Among those species, A. zonatum (Sawada) W. Gams, Bipolaris stenospila (Drechsler) Shoemaker, and C. piaropi were found to be pathogenic to the weed (Conway et al., 1974; Conway, 1976a, b). In a survey conducted in Sri Lanka, 15 fungal pathogens were reported to have co-evolved with water hyacinth (Hettiarachchi et al., 1983). Among those, Myrothecium roridum Tode, C. piaropi, Curvularia tuberculata B.L. Jain, Septofusidium elegantulum (Pidopl.) W. Gams, and Phaeotrichoconis crotalariae (M.A. Salam \& P.N. Rao) Subram. were capable of producing leaf spots on healthy water hyacinth leaves. In case of the last three species, this phenomenon was recorded for the first time. Similarly, in Sudan, 21 fungal and three bacterial pathogens were isolated, of which Phoma sorghina (Sacc.) Borema, Dorenb., \& Kesteren, and Bacillus Fischer sp. were reported for the first time as potential pathogens of water hyacinth (Abdelrahim and Tawfig, 1984). Martinez and Charudattan (1998) reported that 17 native fungal genera were prevalent in Mexico, and A. zonatum, Alternaria Nees sp., C. piaropi, Fusarium Link sp., and Verticillium Nees sp. were very damaging to water hyacinth.

Evans and Reeder (2001) undertook a survey of fungal pathogens of water hyacinth in the Upper Amazon Basin of Peru and Ecuador. In contrast with the findings of Barreto and Evans (1996), the results indicated that there were many mycobiota associated with water hyacinth in the Upper Amazon Basin. However, among the reported potential fungal pathogens that have excellent pathogenicity in water hyacinth, A. eichhorniae Nag Raj \& Ponnappa, A. zonatum, and C. piaropi were not isolated (Evans and Reeder, 2001). In India (Kerala), Praveena and Naseema (2004) reported 21 fungal pathogens in association with water hyacinth, of which 17 were pathogenic. In Egypt, El-Morsy (2004) reported 22 fungal isolates from water hyacinth of which A. alternata Nag Raj \& Ponnappa, D. hawaiiensis (Bugnic.) Subram. \& B.L. Jain, D. australiensis (Bugnic.) Subram. \& B.L. Jain, D. halodes (Drechsler) Subram. \& B.L. Jain, R. solani J.G. Kuhn, and U. atrum Preuss were pathogenic. From these, $D$. hawaiiensis and $U$. atrum were isolated from water hyacinth for the first time. In China, from a survey conducted in 2003 and 2004, nine pathogenic fungi of water 


\section{Chapter 1}

hyacinth were isolated (Ding et al., 2008). Among them, two pathogens were reported to have potential as biocontrol agents for the management of water hyacinth.

In general, more than 90 plant pathogens co-evolved with water hyacinth, and several highly virulent fungal pathogens are known to cause diseases of water hyacinth. Table 3.2 of this thesis provides a list of mycobiota recorded on water hyacinth in different parts of the world.

\subsubsection{Joint use of insects and pathogens as bioagents of water hyacinth}

Success in weed biological control often requires the release and establishment of multiple agents exerting cumulative impacts (Denoth et al., 2002). In most biological weed control projects, the highest levels of 'success' have been achieved using multiple agents due to cumulative or synergistic effects of all agents working together (Impson et al., 2008). Since different bioagents have better performance under different conditions (Day et al., 2003), introduction of more agents may ultimately provide a higher probability of biological control over wider geographical ranges. Similarly, Moran (2005) reported that additive or synergistic effects among introduced and native insects and plant pathogens are necessary to achieve good biological control of water hyacinth. Associations among weed biological control agents may arise if the infestation by one agent directly alters the ability of the others to infest the target. Positive interactions between insect herbivores and plant pathogenic fungi are potentially applicable in biological weed control. Moran $(2004,2005)$ reported that adult Neochetina weevils feeding on the laminae of young leaves were positively correlated to $C$. piaropi induced necrosis on old leaves. Moreover, Martinez and Gomez (2007) concluded from their study in Mexico that complete control of the weed was achieved within three months through integrated management of water hyacinth using insects (the Neochetina weevils) and plant pathogens (C. piaropi and $A$. zonatum).

\subsection{General and specific objectives}

The overall goal was to assess the problem of water hyacinth and to develop an effective biocontrol strategy for water hyacinth, especially in lakes, dams, irrigation canals and reservoirs in the Rift Valley of Ethiopia, based on the efficient use of fungi and weevils. The specific objectives were:

- To determine the prevalence and agro-ecological distribution of water hyacinth (Chapter 2);

- To identify the fungal pathogens found in association with water hyacinth (Chapters 3 and 4); 
- To assess the extent of fungal pathogen controlling potential in decreasing the number and vigour of water hyacinth plant and/or leaf area per plant (Chapter 4);

- To determine adaptability and length of developmental stages of the Neochetina weevils (Chapters 3 and 5);

- To evaluate efficacy of the Neochetina weevils in water hyacinth control (Chapters 5 and 6 );

- To evaluate synergistic effects of the integrated use of Neochetina weevils and potential fungal pathogens for the management of water hyacinth in the Rift Valley of Ethiopia (Chapter 7); and

- To compare and evaluate the application of the protocol and its results in Ethiopia with established results and experiences in the region (Chapter 8).

\subsection{Outline of the thesis}

In Chapter 2, the prevalence, agro-ecological distribution and sources of infestation of water hyacinth, investigations on the socio-economic impact of water hyacinth, and the changes in its agro-ecological distribution are discussed. Univariate as well as multivariate statistical tools are applied to diagnose factors that contribute to the prevalence of water hyacinth. Chapter 3 presents the use of insects and pathogens, their host specificity and their herbivory/virulence effect, as well as recent advances in the use of those bioagents to manage water hyacinth. A modelling tool, CLIMEX, has been applied to predict the potential distribution and adaptability in Ethiopia for $N$. eichhorniae and N. bruchi. The opportunities for extending the use of those bioagents in Ethiopia were evaluated and used in the subsequent chapters of this thesis. In Chapter 4, fungal pathogens found in association with water hyacinth are identified. Both morphological and molecular characterization techniques are applied to characterize the fungal pathogens. Pathogenicity and host-specificity of the fungal pathogens are explored. Chapter 5 assesses the adaptability and duration of developmental stages of Neochetina weevils and the damage they cause to water hyacinth. Moreover, this chapter also explains the life cycle of the two weevils. In Chapter 6, the host specificity, potential efficacy and optimum densities of the two weevils (N. bruchi and N. eichhorniae) as water hyacinth control agents are discussed. Chapter 7 evaluates the integrated use of N. eichhorniae and N. bruchi, both hostspecific herbivorous weevil species, and an indigenous plant pathogen (A. alternata) for controlling water hyacinth. Finally, Chapter 8 consolidate major findings of the study, compares findings of the study with established results in Africa and discuss the potential contribution to be made to improve water hyacinth management in Ethiopia as well as its relevance to the Lower Nile Basin countries. 

CHAPTER 2

\section{Water hyacinth in the Rift Valley water bodies of Ethiopia: Its distribution, socio-economic importance and management}

Y. Firehun, P.C. Struik, E.A. Lantinga and T. Taye (2014)

International Journal of Current Agricultural Research 3(5): 67-75 


\begin{abstract}
A survey was conducted in the Rift Valley water bodies of Ethiopia from 2009 to 2011 to (i) determine the prevalence, agro-ecological distribution and sources of infestation of water hyacinth, (ii) investigate the socio-economic impact of water hyacinth, and (iii) assess changes in its agro-ecological distribution. Water hyacinth was first introduced into the Rift Valley water bodies as an ornamental plant in the 1950s around the Aba-Samuel Dam. Eventually, it spread into Lake Koka, Lake Ellen, Koka Dam and Wonji site via the Awash River. Now it is common in various water bodies located at low, mid and high altitudes. At Lake Koka, Lake Ellen, Aba-Samuel Dam and Koka Dam, an increase in water cover was observed during the study period. Univariate as well as principal component analysis analysis indicated that rainfall, intensity of wave action on the water bodies, water depth, $\mathrm{N}$ and $\mathrm{P}$ content of the water bodies were the factors representing the majority of correlations with water hyacinth coverage. Interviews revealed that the weed mats had an adverse socio-economic impact on the local communities and enterprises. The present assessment also noted that no major management strategy had been employed in the infested water bodies except at Wonji and Koka Dam where a significant reduction (i.e., $<7 \%$ distribution) has been achieved. On the contrary, increasing trend of water hyacinth invasion had been observed in the upstream water bodies. Hence, effective management strategy should be implemented in the upstream water bodies so as to sustain achievements in Wonji.
\end{abstract}

Keywords: Agro-ecological distribution, control measures, economic significance, Eichhornia crassipes, infestation level, PCA, water hyacinth 


\subsection{Introduction}

Water hyacinth, Eichhornia crassipes, is considered as one of the world's worst weeds (Holm et al., 1977), invading lakes, ponds, canals, and rivers. Because of its extremely fast growth, the weed has become the major floating water weed of tropical and subtropical regions. In the absence of natural enemies, the weed quickly becomes invasive, colonizing slow moving waters resulting in thick and extensive mats (Edwards and Musil, 1975) which degrade aquatic ecosystems and limit their utilization (Hill and Coetzee, 2008). The negative impacts of water hyacinth are due to its dense, impenetrable mats which restrict access to water. These mats affect fisheries and related commercial activities, functioning of irrigation canals, navigation/ transport, hydro-electric programmes and tourism (Navarro and Phiri, 2000). Ecologically, benthic and littoral diversity is reduced (Masifwa et al., 2001; Toft et al., 2003; Midgley et al., 2006), while population of vectors of human and animal diseases such as bilharzias and malaria are increased with water hyacinth infestation as these plants interfere with pesticide application (Harley et al., 1996).

Water hyacinth was introduced into Africa from South America in the early 1900s (Mitchell, 1985; Gopal, 1987), but since the 1950s it has become a problematical weed in Southern Africa, the Congo basin and the Upper Nile (Rzoska, 1974; Denny, 1984). In the East African region, the weed was first noticed almost simultaneously in Uganda, Tanzania and Kenya in 1987 (Ogwang and Molo, 1999). An exploratory survey was undertaken to assess the prevalence of water hyacinth on the different water bodies of Ethiopia. Results of this survey indicated that the weed infestation was small at that time and no subsequent action was taken. However, sporadic visits, including some clean-up attempts have been made during 1959, 1968, 1979 and 1988 (Stroud, 1994). There are also reports indicating the infestation of water hyacinth especially in Baro, Gillo, and Akobo Rivers in Western Ethiopia (Rezene, 2005). Recently, water hyacinth infestation has also been observed in Lake Tana.

At Wonji-Shoa sugar estate, the weed began to proliferate on reservoirs, irrigation and drainage structures since 1996 when the plantation was flooded by overflow of the Awash River that crosses the Koka Dam (Firehun et al., 2007). As of 2005, the gravity of the situation was quickly realized and it was decided to embark a management strategy of the weed nationally. An action-oriented control programme involving manual, mechanical, biological and chemical measures (Firehun et al., 2007; EIAR/UNEP-GEF, 2009) was launched; but only the manual, chemical and mechanical control programmes were effectively implemented. Although in some of the infested areas these control programmes were implemented (Dula et al., 2008, Taye et al., 2009), further spread of water hyacinth in the Rift Valley of Ethiopia was 
not stopped. However, to gauge the severity of the problem, reliable estimates of water hyacinth distribution and abundance are required.

Knowledge of the weed community structure is an important component of weed management and is essential in setting priorities for weed management. Currently, to cope with the water hyacinth problems, the need for integrated use of manual, mechanical and biological control measures is widely recognized. Implementation of such control measures in an integrated manner requires reliable estimates of water hyacinth distribution, identification of water bodies that require management action and assessment of existing control measures and their efficacy. For effective management of this weed, identifying source of infestation and route of transportation is very crucial. Thus, the objectives of this study were to determine the prevalence, agro-ecological distribution of water hyacinth and sources of infestation; to investigate the socio-economic impact of water hyacinth; and to assess the change in distribution and impact of the existing control measures on the weed cover over the last three years in the Rift Valley of Ethiopia.

\subsection{Materials and methods}

\subsubsection{Survey sites}

A survey was done in and along Aba-Samuel Dam, Lake Bishoftu, Lake Koka, Lake Beseka, Koka Dam, Awash Dam, Lake Ellen, Lake Elltoke, Wonji-Shoa sugar estate, Metahara sugar estate, Melka-Sedi and Melka-Werer following the streams of the Awash River. Central Rift Valley lakes namely Beseka, Koka, Ziway, Langano, Abiyata, Shala, Abaya, Chamo and Awassa were also assessed. These sites are situated from low (< $1300 \mathrm{~m}$ a.s.l.) to high ( $>1900 \mathrm{~m}$ a.s.1.) altitude and receive an annual rainfall ranging between 950 and $1500 \mathrm{~mm}$. Geographic and bathymetric characteristics of the Rift Valley lakes and Koka Dam are indicated in Table 2.1.

\subsubsection{Survey procedure}

A survey was conducted twice per year between 2009 and 2011. In these surveys, hydro dams, lakes, irrigation and drainage structures found in the Rift Valley and in the Awash River down to Melka-Werer were examined for possible infestation by water hyacinth. Within the Rift Valley, survey sites were selected on the basis of the presence of water bodies and their accessibility. Water bodies were identified from the reports of the respective administrative zone agricultural office and preliminary assessment (EARO, 2003). In the surveyed water bodies, the existing aquatic environments were inspected for water hyacinth infestation. After identification of infested water bodies, the geographic coordinates (altitude, latitude and longitude) 
Table 2.1. Geographic and bathymetric characteristics of Rift Valley lakes and dams in Ethiopia (after: Tenalem, 2004).

\begin{tabular}{lrccr}
\hline Lakes/Dam & $\begin{array}{c}\text { Altitude } \\
(\mathbf{m} \text { a.s.l.) }\end{array}$ & $\begin{array}{r}\text { Water body area } \\
\mathbf{( k m}^{\mathbf{2}}\end{array}$ & $\begin{array}{c}\text { Mean depth } \\
\mathbf{( m )}\end{array}$ & $\begin{array}{r}\text { Volume } \\
\mathbf{( 1 0}^{\mathbf{6}} \mathbf{m}^{\mathbf{3}} \mathbf{)}\end{array}$ \\
\hline Aba-Samuel Dam & 2050 & 20 & 2.0 & - \\
Lake Elltoke & 1700 & 12 & 3.0 & - \\
Lake Ellen & 1700 & 28 & 2.5 & - \\
Lake Beseka & 952 & 40 & 6.0 & - \\
Koka Dam & 1584 & 177 & - & 1850 \\
Lake Ziway & 1636 & 440 & 2.5 & 1466 \\
Lake Langano & 1585 & 230 & 17.0 & 3800 \\
Lake Abiyata & 1580 & 180 & 7.6 & 957 \\
Lake Shala & 1550 & 370 & 8.6 & 37000 \\
Lake Abaya & 1285 & 1162 & 7.1 & 8200 \\
Lake Chamo & 1233 & 551 & - & - \\
Lake Awassa & 1680 & 100 & 10.7 & 1340 \\
\hline
\end{tabular}

were recorded using a GARMIN 12X portable geographic positioning system (GPS).

Extents of water hyacinth infestation were estimated by random sampling of plant population from different corners of the selected water bodies. For water bodies having limited infestation towards the shoreline, plant population count was made by throwing a one meter square quadrat in a zigzag fashion along the shore. For water bodies with infestations at the center, plant population count was made by throwing a quadrat ten times in a ' $\mathrm{X}$ ' fashion systematically over an assumed square encompassing at least most of infested water bodies using local boats. The total number of sample varied depending on prevalence and infestation level of the water bodies to accommodate at least one-tenth of the infested area (Coyne et al., 2007). For water hyacinth infestation starting from outside towards the center, the coverage was measured using a meter tape. A pair of binoculars was used to identify the edge or limit of the infestation. Finally, each infestation level of the weed was given an abundance score following the procedure described by Phillip (1992). These abundance score values were again categorized from high to low infestation level to simplify the distribution map as used by Firehun et al. (2007).

\subsubsection{Change in infestation level}

In order to determine seasonal change in water hyacinth infestation, observations were made between 2009 and 2011. The locations selected for this study were Aba-Samuel Dam, Lake Koka, Lake Ellen and irrigation and drainage structures of Wonji-Shoa 
sugar estate. During the assessment, observations were made from the shoreline and in the lakes using local boats. Point data were recorded about the number of plants per meter square, plant density and overall distribution of the weed. Besides, at each point, the geographic coordinates (altitude, latitude and longitude) were recorded using a GARMIN 12X portable geographic positioning system (GPS). While taking the geographical coordinates, the severity levels of the water hyacinth infestation were assigned by codes ranging from 0 to 5 based on their population density (cluster growth) in the water body as well as nearby water bodies (Phillip, 1992). During each season, visual observation and sampling was conducted to determine: presence of flowers, $\mathrm{pH}$, level of wave action, water depth and level of $\mathrm{N}, \mathrm{P}, \mathrm{K}$ in the water. These measurements and water samples were collected from the ten blocks of the respective severity level of water hyacinth and replicated six times at each site. For the wave action on water bodies and depth of the water bodies, measurements were taken at 1220 points depending on the size of the block. For the water samples, three one-litre samples were taken at each measuring point. After determining depth of the water bodies, the three water samples per measuring point were pooled and kept in a box at room temperature for water quality analysis.

Change in infestation level analysis from year to year was made by developing time series distribution maps. In order to generate the water hyacinth severity map, the geographic coordinates of the water hyacinth taken by GPS were transferred to GIS environment using DNGarmin software, and then those ground control points were projected using the widely used datum geographic coordinate system of 1984 (WGS84). In order to classify the level of severity, those codes transferred into GIS environment were then reclassified into 0, 1, 2-3 and 4-5 which represent free, low, medium and heavy infestation of water hyacinth. While mapping the severity of the water hyacinth, the major water body and river network shape files were collected from the Central Statistics Agency of Ethiopia. Climatic data were also used to assess effect on change in the infestation level of the weeds at the respective water body.

\subsubsection{Data processing of plant survey}

Correlation analysis was conducted using PROC CORR procedure of SAS (SAS Institute, 2008) to identify associations between water quality parameters and climatic data with water hyacinth coverage of the respective water bodies. In order to group the correlated water as well as climatic variables to the smallest possible subsets representing the majority of variation, a principal component analysis (PCA) was conducted further using the PROC FACTOR procedure of SAS (SAS Institute, 2008). The factors derived from the PCA are considered mutually orthogonal, uncorrelated, and successively explain the maximum residual variation. A factor, as an array 
variable, may hold contributions from all the nine variables. Total variance of each factor was defined as eigen value. Factors with eigen values $>1$ and those that explained at least $5 \%$ of the variation in the data were retained. Generally, variables with higher loading coefficients were included in each factor because they could be expected to have greater effect on water hyacinth area coverage variability. Variables with factor loadings $>0.50$ were selected to be included in each factor. Where the loading coefficient of the variable was $>0.50$ in more than one factor, it was included in the factor having the highest coefficient value for that property.

\subsubsection{Socio-economic impact of the weed}

The socio-economic impacts of water hyacinth were assessed through interviewing the local communities and affected enterprise personnel's at Aba-Samuel Dam, Lake Ellen, Lake Koka, Wonji-Shoa Sugar Estate, Ethiopian Electric Power Authority (at Koka Dam), and communities along the Awash River. Structured questionnaires were designed and administered to 185 respondents in the respective sites. Data were also collected from other stakeholders such as governmental organizations, nongovernmental organization (NGOs), and urban dwellers. Secondary information was also collected from published and unpublished sources available from governmental, NGO and international organizations.

The major issues posed in the questionnaires included: 1) awareness of the weed; 2) the time of introduction into the area; 3) rate of spread of the weed since its appearance; 4) impacts on crop and livestock production, on the operations of commercial farms, and on native plant species; 5) the costs incurred and labour required to control/minimize the impacts of the focal species; 6) measures taken so far (by the interviewee and other bodies); 7) success/failure of the measures taken to date; 8) other advantages and disadvantages of the weed. Finally, the questionnaires were coded and the data entered to computer for analysis. Statistical analysis software (SPSS) was used to summarize the information and analyse the data.

\subsubsection{Case study: Impact of physical and herbicidal control measures}

Assessment of the impact of physical and herbicidal control approaches implemented in the Rift Valley water bodies was evaluated taking Wonji-Shoa sugar estate as a case study. Wonji-Shoa irrigation and drainage structures were selected as a case study area because of its long history of water hyacinth control and because data on the cost and control success were available. The water bodies selected for the case study included reservoirs ('WR' and 'WZ')', irrigation supply canals (primary and secondary) and drainage structures (border and central drains) where physical (manual removal,

\footnotetext{
1 'WR' and 'WZ' are local names of the reservoirs at Wonji.
} 
removal with the use of machinery, and canal restructuring) and herbicidal control measures were implemented alone or in combination for the last 12 years (Firehun et al., 2007; Dula et al., 2008). Efficacy of the implemented strategy was evaluated both qualitatively and quantitatively. For qualitative evaluation, visual rating of efficacy was made using the European system of the weed control evaluation scale (Burrill et al., 1976). For quantitative evaluation, percent weed control, percent reduction in dry weight and flower number following the application of control methods were calculated and the two sample t-test was conducted using SAS software (SAS Institute, 2008).

Similarly, data on the plant population, cost of control and other aspect of water hyacinth management were obtained from Wonji-Shoa Sugar Factory Agricultural Operations Office (WSSFAO), from interviews with the relevant people at WSSFAO and from management staff of the Sugarcane Research Directorate office located at Wonji. Evaluation of the cost incurred by the sugar factory to manage this weed was made by considering the impact of water hyacinth on a range of factors. All cost figures were adjusted for inflation using a consumer price index (CPI) with the year 2000 as the baseline.

\subsection{Results and discussion}

\subsubsection{Distribution and status of water hyacinth in the Rift Valley of Ethiopia}

Assessment result indicated that water hyacinth has become a major invasive alien weed in the Rift Valley of Ethiopia having successfully established and invaded the different water bodies. The present field assessment on the prevalence and severity of water hyacinth infestation showed that the weed prevails in most of the Rift Valley lakes, canals, reservoirs, irrigation water supplies and drainage structures with different magnitudes of infestation (Figure 2.1). Among the surveyed water bodies, the highest water hyacinth infestation (4-5 abundance scale) and visual area coverage $(>90 \%)$ was recorded in Lake Ellen and Lake Elltoke. The lowest water hyacinth infestation level (1) and area coverage $(<2 \%)$ were recorded at Wonji-Shoa and Lake Abaya (Table 2.2). Moreover, 20-58\% cover of water hyacinth mat area was recorded at Aba-Samuel Dam, Koka Dam, Awash Dam, Lake Koka, irrigation water supplies and drainage structures found in Melka Hida, Taree and Afer Gideb. In all the three years of survey work, Lake Bishoftu, Lake Cheleka, Lake Ziway, Lake Langano, Lake Awassa, Lake Chamo and Lake Beseka were confirmed to be free of the water hyacinth problem.

Previous assessment reports revealed that water hyacinth was prevalent in AbaSamuel Dam, Lake Koka, Lake Ellen, Wonji-Shoa and Metahara sugar factory 
irrigation structures (Senayit et al., 2004; Rezene, 2005; Taye et al., 2009). New records of water hyacinth infestation on Lake Abaya and Lake Elltoke were observed in the present survey.

In all surveyed water bodies, there was a high degree of variability in water hyacinth infestation (Figure 2.1). Most of the water bodies of Lake Ellen and Elltoke were predominated with high water hyacinth infestation and a few spots had low to medium infestation. These lakes are located near the farm lands and even part of them is cultivated when the water level decreases. This might have created a high influx of nutrients into the lake which favoured high reproduction rate of the weed. As a result, the weed forms mats covering all or part of these lakes. Severe water hyacinth infestation was also observed at Koka Dam, near Sire Robe peasant association (PA) and at the upper Koka near Tere PA in Koka Lake and on Awash River (to the side of Bora District).

At Aba-Samuel Dam, the overall magnitude of water hyacinth infestation was relatively low (Table 2.2). However, as observed in the main rainy season assessment, the infestation was high during the months of August and September. In October,
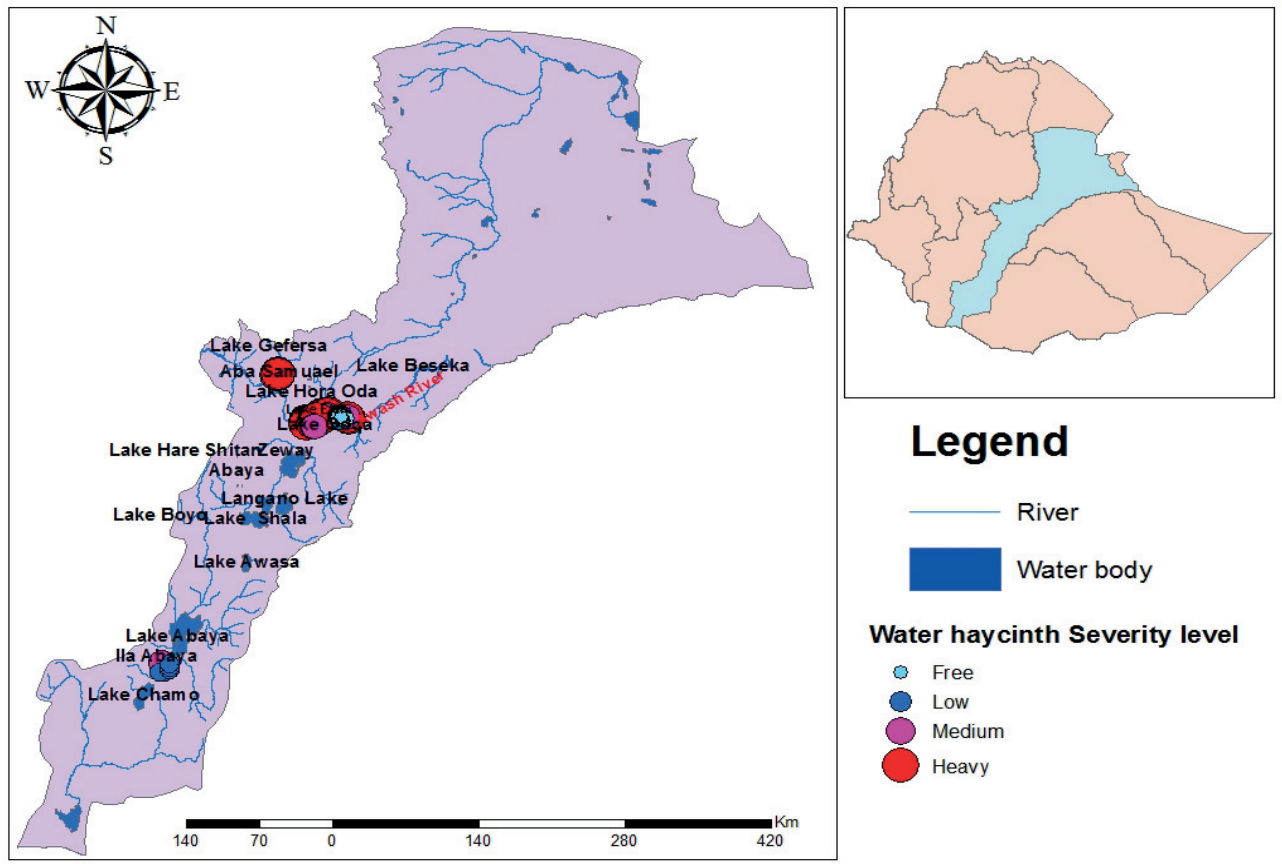

\section{Legend}

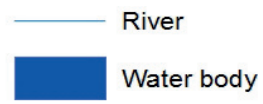

Water haycinth Severity level

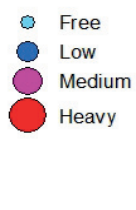

Figure 2.1. Distribution of water hyacinth in the Rift Valley water bodies of Ethiopia. 
Table 2.2. Mean water hyacinth infestation level and overall coverage in the Rift Valley water bodies, Ethiopia.

\begin{tabular}{|c|c|c|c|c|c|}
\hline Water bodies & $\begin{array}{l}\text { Altitude } \\
\text { (m a.s.l.) }\end{array}$ & $\begin{array}{c}\text { Mean fresh } \\
\text { weight } \\
\left(\mathrm{kg} \mathrm{m}^{-2}\right)\end{array}$ & $\begin{array}{l}\text { Mean plant } \\
\text { population } \\
\left(\text { plants } \mathbf{m}^{-2}\right)\end{array}$ & $\begin{array}{c}\text { Infestation } \\
\text { level }\end{array}$ & $\begin{array}{c}\text { Observed } \\
\text { coverage } \\
(\%)\end{array}$ \\
\hline Aba-Samuel Dam & 2052 & 7.0 & 67 & Low-High & 46 \\
\hline Lake Ellen & 1700 & 44.0 & 276 & High & 100 \\
\hline Lake Elltoke & 1700 & 42.0 & 248 & High & 92 \\
\hline Lake Koka & 1589 & 23.0 & 298 & Free-High & 37 \\
\hline Koka Dam & 1580 & 21.0 & 308 & Free-High & 30 \\
\hline $\begin{array}{l}\text { Wonji-Shoa } \\
\text { sugar factory }\end{array}$ & 1500 & 3.0 & 23 & 7 & $<7$ \\
\hline $\begin{array}{l}\text { Metahara } \\
\quad \text { sugar factory }\end{array}$ & 950 & 0.0 & 0 & Free & 0 \\
\hline Melka Hida & 1450 & 6.0 & 58 & Free-Low & 20 \\
\hline Afer Gideb & 1539 & 15.0 & 261 & Free-High & 55 \\
\hline Taree & 1580 & 13.0 & 211 & Medium-High & 58 \\
\hline Awash & 1460 & 10.0 & 186 & Medium-High & 42 \\
\hline Lake Abaya & 1285 & 0.1 & 6 & Free-Low & $<1$ \\
\hline
\end{tabular}

water hyacinth mats were broken and moved towards the shoreline. This dam had also high level of organic residues that might have come from the nearby factories and home waste disposal located in the capital city, Addis Ababa. In general, the majority of this aquatic plant was concentrated in the shoreline of the water bodies, on mud and sediments where disturbance by wind is relatively small. Part of the water bodies around the center remained clear with few floating plants which were detached as a result of the wind blown over the lake. In agreement to this result, many reports indicated that water level fluctuation, wave action, presence of suitable water hyacinth habitat, level of eutrophication associated with agricultural practice and the large urban areas would affect population dynamics of water hyacinth (Gopal, 1987; Wilson et al., 2001; Albright et al., 2004; Wilson et al., 2005; Kateregga and Sterner, 2007). Thus, the confined distribution of the weed to the shoreline of the surveyed lakes and dams could be attributed by the high wind current blown over the water bodies and reduced water level.

The number of plants in these water bodies varied from none to more than 300; the highest plant population count (308 plants $\mathrm{m}^{-2}$ ) was recorded in Koka Dam followed by Lake Koka (298 plants $\mathrm{m}^{-2}$ ), Lake Ellen ( 276 plants $\left.\mathrm{m}^{-2}\right)$, Lake Elltoke (248 plants 
$\mathrm{m}^{-2}$ ), Afer Gideb (261 plants $\mathrm{m}^{-2}$ ), Taree and Awash (211 and 186 plants $\mathrm{m}^{-2}$ ). Similarly, the highest weed density $\left(>40 \mathrm{~kg} \mathrm{~m}^{-2}\right.$, fresh weight) was recorded at Lake Ellen and Elltoke. Medium water hyacinth density $\left(6-40 \mathrm{~kg} \mathrm{~m}^{-2}\right)$ was also recorded in the water bodies of Lake Koka, Aba-Samuel Dam, Koka Dam, Awash Dam, and irrigation water supplies at Taree and Afer Gideb. In agreement with this result, reports indicated that outside its native range water hyacinth can grow quickly to a very high density, thereby completely clog water bodies (Fernandez et al., 1990; Julien et al., 1996). Wilson et al. (2005) also predicted a linear reduction relation between water hyacinth density (fresh weight) and specific growth rate. This indicates that it is not surprising to have variability in the weed density considering the reproduction rate of the weed outside its native area. Thus, the difference in extent of infestation within the infested water bodies of the Rift Valley water bodies indicates the relative clogging and expansion potential of the weed in the specific water body.

\subsubsection{Correlation analysis}

Significant correlations were observed between water quality factors and water hyacinth coverage as well as between climatic factors and water hyacinth coverage (Table 2.3). Water hyacinth coverage was positively correlated with rainfall (RF), N, $\mathrm{P}, \mathrm{K}$ and temperature (T) and negatively correlated with depth of the water bodies and altitude. Strong positive correlations were observed between the water hyacinth distribution, RF as well as $\mathrm{T}(\mathrm{r}=0.57-0.97, \mathrm{P}<0.001)$ in all the surveyed water bodies. Nitrogen, phosphorus, and potassium $(\mathrm{r}=0.63-0.97, \mathrm{P}<0.001)$ showed positive correlation with water hyacinth coverage at Aba-Samuel Dam, Lake Ellen, Lake Elltoke, Lake Koka and Koka Dam, and Melka Hida.

Similarly, except at Wonji-Shoa, strong negative correlations ( $r=-0.52$ to -0.93 , $\mathrm{P}<0.001$ ) were observed between depth of water and the weed infestation in all the water bodies. The result also indicated that both the positive and negative associations between the weed infestation, water as well as climatic factors was mainly attributed to the nutrient influx (N, P, K), wave action and depth of the water bodies (W and WD). Among the water bodies, the strong association between the nutrient influx, wave action and depth of the water bodies was very apparent in Aba-Samuel Dam, Lake Ellen, Lake Elltoke and Lake Koka.

Furthermore, PCA was performed using the nine water quality and climatic variables selected from the univariate screening procedure. The factor analysis revealed that the main factors representing the majority of correlations were associated with five factors. Each of the first five groups or factors had eigen value $>1$ and was retained for interpretation (Table 2.4). These five factors explained cumulative sample variance of $83 \%$. The first and the most important factor, which explained $46 \%$ of the 
Table 2.3. Correlation coefficients of water quality and climatic variables with water hyacinth coverage in the Rift Valley water bodies of Ethiopia.

\begin{tabular}{lccccccccc}
\hline & \multicolumn{8}{c}{ Water and climatic factors } \\
Water bodies & AL & W & WD & pH & N & P & K & RF & T \\
\hline Aba-Samuel Dam & -0.10 & 0.97 & -0.93 & 0.29 & 0.92 & 0.93 & 0.97 & 0.97 & 0.77 \\
Lake Ellen & -0.29 & 0.87 & -0.77 & 0.30 & 0.98 & 0.88 & 0.73 & 0.98 & 0.75 \\
Lake Elltoke & -0.29 & 0.80 & -0.69 & 0.33 & 0.90 & 0.86 & 0.75 & 0.92 & 0.74 \\
Lake Koka & -0.13 & 0.93 & -0.91 & 0.02 & 0.80 & 0.80 & 0.74 & 0.89 & 0.81 \\
Koka Dam & -0.18 & 0.55 & -0.63 & 0.16 & 0.68 & 0.66 & 0.63 & 0.88 & 0.75 \\
Wonji-Shoa & -0.22 & 0.38 & -0.09 & 0.16 & 0.48 & 0.47 & 0.39 & 0.63 & 0.69 \\
$\quad$ sugar factory & & & & & & & & & \\
Melka Hida & -0.37 & 0.63 & -0.62 & 0.11 & 0.58 & 0.57 & 0.54 & 0.68 & 0.70 \\
Afer Gideb & -0.20 & 0.53 & -0.52 & 0.18 & 0.50 & 0.48 & 0.44 & 0.70 & 0.69 \\
Taree & -0.05 & 0.64 & -0.60 & 0.33 & 0.51 & 0.43 & 0.54 & 0.73 & 0.57 \\
Awash & -0.43 & 0.56 & -0.52 & 0.20 & 0.26 & 0.34 & 0.24 & 0.92 & 0.69 \\
Lake Abaya & -0.16 & 0.58 & -0.53 & 0.25 & 0.50 & 0.50 & 0.42 & 0.57 & 0.62 \\
\hline
\end{tabular}

Note: AL, altitude; W, wave action on the water bodies; WD, depth of the water bodies; $\mathrm{pH}$, $\mathrm{pH}$ of the water; $\mathrm{N}$, nitrogen content; $\mathrm{P}$, phosphorus content; $\mathrm{K}$, potassium content; RF, rainfall; $\mathrm{T}$, Temperature.

variation, had high factor loading $(>0.50)$ for properties such as RF, $\mathrm{K}$ and T. Factor 2 had high loading from $\mathrm{pH}$ and $\mathrm{N}$ and collectively they explained $13 \%$ of the sample variance. The highly weighted variables under Factor 3 were altitude (AL) and wave action (W). Water depth (WD) from Factor 4 and $\mathrm{K}$ from Factor 5 were selected as highly weighted variables. Correlation coefficients among RF, K and T under Factor 1 were strongly correlated (Table 2.4). The RF was selected as a representative from Factor 1 because it had the highest factor loading of 0.85 . Under Factor 2, $\mathrm{pH}$ and $\mathrm{N}$ were significantly correlated. $\mathrm{N}$ with the highest factor loading of 0.92 was selected to represent Factor 2.

Similarly, W and WD were selected as representatives from Factors 3 and 4, respectively. Only $\mathrm{P}$ was ranked as highly weighted from Factor 5, which was also added to the dataset. The final variables selected were RF, N, W, WD and P. In line with this, reports indicated that population dynamics of water hyacinth can be affected by the water level fluctuation and wave action (Gopal, 1987; Wilson et al., 2001). Reddy et al. (1990) reported that optimum growth of water hyacinth occurs in still or slowly moving water with high relative humidity, long sun exposure, a temperature range between $28{ }^{\circ} \mathrm{C}$ and $30^{\circ} \mathrm{C}$, a pH of 7 and on abundant nitrogen, phosphorus and potassium. 
Table 2.4. Factor analysis results based on nine water and climatic variables.

\begin{tabular}{lccccc}
\hline Factors & Factor 1 & Factor 2 & Factor 3 & Factor 4 & Factor 5 \\
\hline Eigen value & 4.55 & 1.65 & 1.24 & 1.10 & 0.99 \\
Percent variance & 45.50 & 13.50 & 10.40 & 8.00 & 5.90 \\
Cumulative variance & 45.50 & 59.00 & 69.30 & 77.30 & 83.20 \\
Eigen vectors & & & & & \\
AL altitude & 0.02 & -0.46 & $\mathbf{- 0 . 7 2}$ & -0.43 & -0.12 \\
RF rainfall & $\underline{\mathbf{0 . 8 5}}$ & -0.06 & -0.04 & 0.18 & -0.18 \\
pH of the water & -0.18 & $\mathbf{- 0 . 6 1}$ & 0.36 & -0.07 & -0.08 \\
N nitrogen & -0.34 & $\underline{\mathbf{0 . 9 2}}$ & -0.18 & 0.11 & 0.15 \\
P phosphorus & -0.39 & 0.38 & -0.01 & 0.09 & $\underline{\mathbf{0 . 7 7}}$ \\
K potassium & $\mathbf{- 0 . 5 5}$ & -0.06 & 0.03 & -0.19 & $\mathbf{0 . 5 8}$ \\
W wave action & -0.39 & -0.21 & $\underline{\mathbf{0 . 8 7}}$ & 0.06 & -0.26 \\
WD water depth & 0.19 & -0.32 & -0.35 & $\underline{\mathbf{0 . 8 3}}$ & 0.14 \\
T temperature & $\mathbf{0 . 8 3}$ & -0.24 & 0.27 & 0.18 & -0.44 \\
\hline
\end{tabular}

\subsubsection{Change in infestation level}

A rapid change in the infestation levels of water hyacinth was recorded during the survey period, mainly at Akaki site (Aba-Samuel Dam), Alem Tena site (Lake Ellen), Koka site (Lake Koka and Koka Dam) and Wonji site (reservoirs, irrigation supplies and drainage canals) water bodies (Figure 2.2). The data showed a rapid increase in water hyacinth abundance during the 2011 survey followed by the 2010 survey conducted at Aba-Samuel Dam, Lake Ellen, Lake Koka and Koka Dam. During the 2011 survey period, the distribution map developed through GIS software revealed giant mats of water hyacinth covering large areas of the water bodies contrary to the mats formed in 2009. This aquatic weed infestation in the reservoirs, irrigation supplies and drainage canals located at Wonji site showed a rapid decline over the three years. In the interviews with the local communities, it was noted that no major management strategy had been employed in these water bodies except at Wonji and Koka Dam. A nutrient content of 2.8-3.0 $\mathrm{mg} \mathrm{l}^{-1} \mathrm{~N}\left(\right.$ mean $\left.=2.9 \mathrm{mg} \mathrm{l}^{-1} \mathrm{~N}\right)$ and 1.2-1.5 $\mathrm{mg} \mathrm{l}^{-1} \mathrm{P}\left(\right.$ mean $\left.=1.3 \mathrm{mg} \mathrm{l}^{-1} \mathrm{P}\right)$ had been recorded in all the infested water bodies. In line with this result, Heard and Winterton (2000) reported a nutrient content of $3 \mathrm{mg} \mathrm{l}^{-1}$ $\mathrm{N}$ and $1.3 \mathrm{mg} \mathrm{l}^{-1} \mathrm{P}$ to be high for water hyacinth growth and development. Hence, the giant mat covering in the water bodies of Akaki, Alem Tena and Koka sites could be associated with suitable habitat created for the weed growth and development.

Analysis of the change in infestation level over the last three years in these water bodies also indicated that stationary and mobile mats of water hyacinth were formed. The surface area of the water bodies covered by the mats varied from year to year. As 
Chapter 2

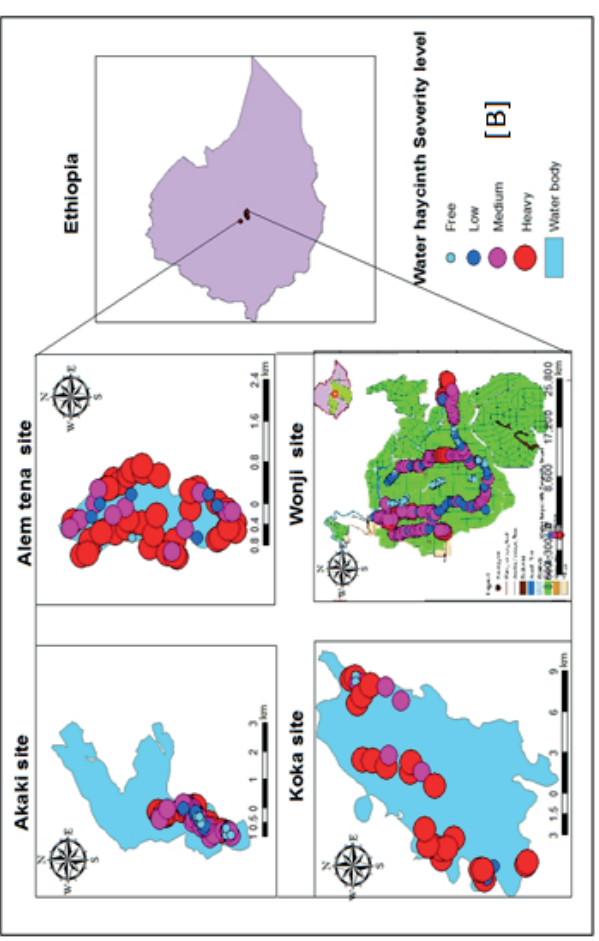

范

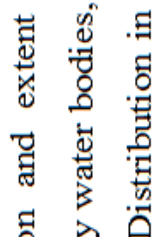

总忞

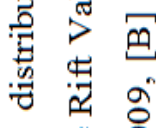

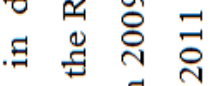

品 $\Xi . \Xi$

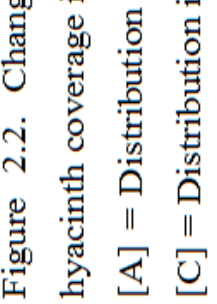
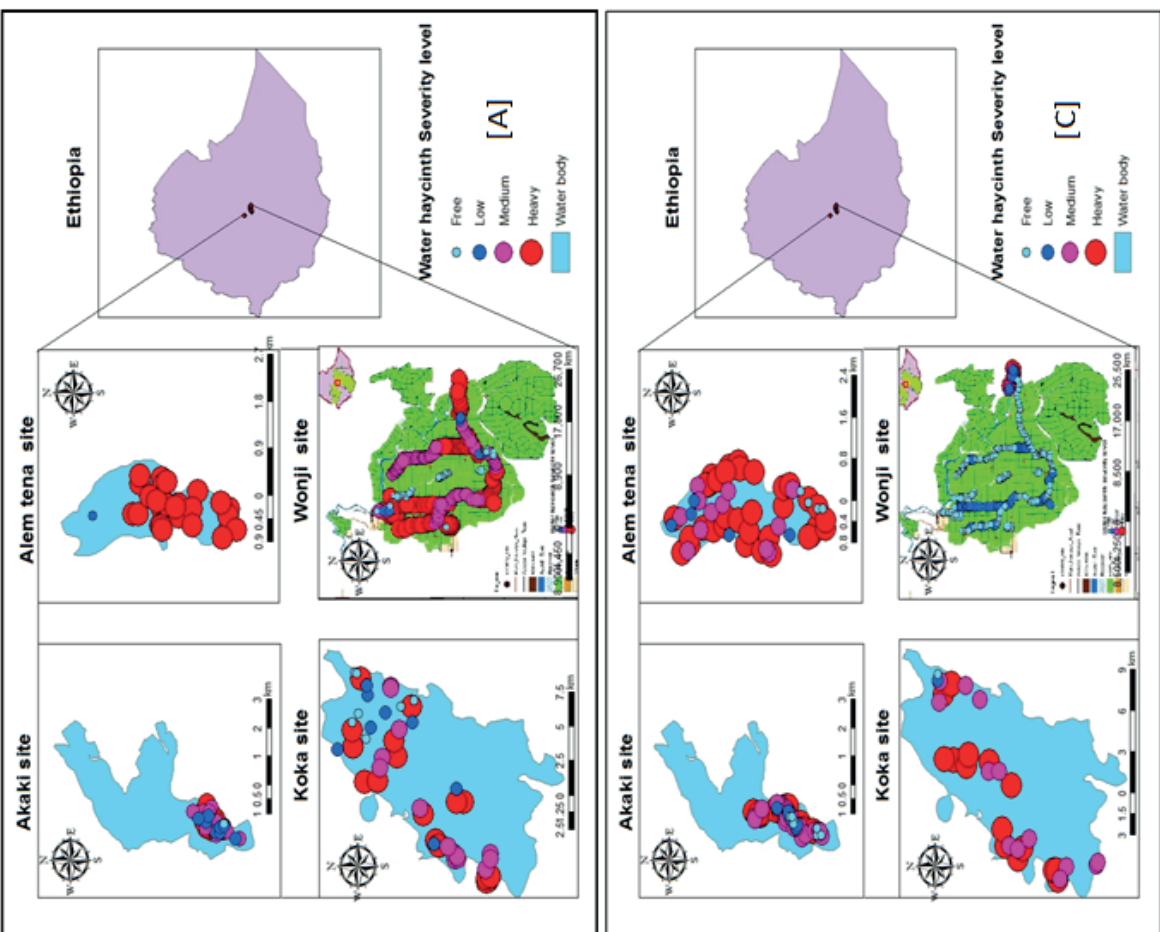
shown in Figure 2.2, during 2009, the mats located at Aba-Samuel Dam, Lake Ellen, Lake Koka and Koka Dam were sparse and more mobile than during the years 2010 and 2011. However, during 2010 and 2011, the mats recorded in these water bodies were stationary. In this regard, meteorological data of the study area during these periods indicated the presence of heavy winds and waves associated with heavy rain which might have physically damaged plants and dislodged mats (Table 2.3). Hence, the difference in mat type could be attributed to the difference in extent of wind, waves, extent of rainfall, and the water level. In line with this, Albright et al. (2004) reported that heavy winds and waves associated with heavy rain significantly contribute to the variation in extent of water hyacinth infestation and mat size in the Lake Victoria basin. Severity of water hyacinth infestation was also greater in the border parts of the lakes and dams compared to the central part (Figure 2.2). This might be linked to the water currents and weather patterns that push the weed to the shoreline.

During the field assessment, flowering water hyacinth plants were observed in all the surveyed water bodies. Water aided movement of individual plants has been observed from Aba-Samuel Dam via the Awash River down to Lake Koka, Lake Ellen, and Wonji sites. Therefore, these sexual and asexual reproduction mechanisms entail the water hyacinth to be a threat to the continued use of the affected water bodies as a resource.

\subsubsection{Socio-economic impact of the weed}

Water hyacinth was the most abundant aquatic weed on the water bodies studied and perceived as one of the most important noxious weeds (Table 2.5) showing high rate of spread within the last 60 years from its introduction. From the interviews conducted during the study, communities in Aba-Samuel generally believed that this aquatic weed was introduced to their area as an ornamental plant in the 1950 s by foreign experts who were employed at the Dam site.

Communities in Lake Koka, Lake Ellen, Wonji-Shoa sugar factory (WSSF) and Ethiopian electric power authority (EEPA) have different views on its introduction such as by plant parts with running water and with flood, indicating its likely secondary dispersal from Aba-Samuel Dam. Field observation also confirmed that the weed found its way into the Rift Valley water bodies from Aba-Samuel Dam, which opens into the Awash River reroute to Lake Ellen, Lake Elltoke, Lake Koka, and Koka Dam. Consequences of infestation are often dramatic and now the weed is spreading to different water bodies located in the Rift Valley.

Of the 185 interviewees, 93\% in Aba-Samuel, 92\% in Lake Koka and 90\% in Lake Ellen were aware of the problem of water hyacinth on grazing and crop production 
activities, irrigation and drainage system and/or fishing. In WSSF and EEPA, 100\% of the interview was aware of the problem on irrigation and drainage system, power generation and/or proper water flow. Of the communities aware of the weed, $68 \%$ in Aba-Samuel, $75 \%$ in Lake Koka, and $60 \%$ in Lake Ellen considered water hyacinth to have a significant impact on grazing and crop production activities whereas $88 \%$ in WSSF and $84 \%$ in EEPA considered it to have an impact on irrigation and drainage system and power generation, respectively.

As reported by the communities living around the affected water bodies, impact of water hyacinth gets higher whenever there were mats. The most noticeable impacts that were reported by most interviewee include: restricting proper water flow, water loss through excessive evapo-transpiration, interference with fishing, grazing and crop production activities (accessibility to land water hindered), effect on power generation, increase siltation, flooding, increase cost of production and effect on native plants. Though vital epidemiological data pertaining to incidence of human diseases were not obtained during this study, there is a general increase in disease incidences as a result of provision of vector breeding grounds. Some of the human diseases reported include: skin rash, malaria, and bilharzias.

Table 2.5. Respondents' view on water hyacinth in the Rift Valley of Ethiopia.

\begin{tabular}{lrrrrr}
\hline & \multicolumn{4}{c}{ Water bodies } \\
\cline { 2 - 6 } & $\begin{array}{c}\text { Aba- } \\
\text { Samuel } \\
\text { Dam }\end{array}$ & $\begin{array}{c}\text { Lake } \\
\text { Koka }\end{array}$ & $\begin{array}{c}\text { Lake } \\
\text { Ellen }\end{array}$ & WSSF & EEPA \\
Questions & $(\mathrm{n}=35)$ & $(\mathrm{n}=65)$ & $(\mathrm{n}=40)$ & $(\mathrm{n}=45)$ & $(\mathrm{n}=10)$ \\
\hline Awareness about the weed status (\%) & 93 & 92 & 90 & 100 & 100 \\
$\quad$ Yes & 7 & 8 & 10 & 0 & 0 \\
No & $(\mathrm{n}=32)$ & $(\mathrm{n}=60)$ & $(\mathrm{n}=36)$ & $(\mathrm{n}=45)$ & $(\mathrm{n}=10)$ \\
Means of introduction (\%) & 0 & 13 & 6 & 97 & 45 \\
With flood & 95 & 0 & 3 & 0 & 0 \\
By foreigners & 0 & 0 & 3 & 0 & 0 \\
With local fishing boats & 5 & 87 & 88 & 3 & 55 \\
With running water & $(\mathrm{n}=32)$ & $(\mathrm{n}=60)$ & $(\mathrm{n}=36)$ & $(\mathrm{n}=45)$ & $(\mathrm{n}=10)$ \\
Impact of the weed on (\%) & 7 & 7 & 23 & 0 & 0 \\
Grazing animals only & 68 & 75 & 60 & 0 & 0 \\
Both grazing animals and crop & & & & & 0 \\
$\quad$ production & 0 & 18 & 0 & 0 & 0 \\
Fishing activities & 25 & 0 & 17 & 88 & 0 \\
Irrigation and drainage system & 0 & 0 & 0 & 12 & 16 \\
Proper water flow & 0 & 0 & 0 & 0 & 84 \\
Power generation & & & &
\end{tabular}


These results showed that the impact of water hyacinth may be categorized into social, economical and environmental impacts. Fishers, riparian communities, Institute of Biodiversity, National Agricultural Research Institute, sugar corporation/sugar factories, Ministry of Energy and Water Resources, Ministry of Agriculture and Environmental Protection Authority were identified as the organizations and communities affected by this noxious weed. Similarly, other studies have indicated that the weed poses a great threat to agriculture, fisheries, transportation, hydroelectric power generation, health and the environment (Ding et al., 2001; Mailu, 2001; Center et al., 2002; Midgley et al., 2006). Although no beneficial aspects of the weed were reported by the interviewees, $10 \%$ of them also reported its use as a feed for their animals.

Following the remarkable spread and enormous impact of the water hyacinth at WSSF and EEPA, management strategy, namely, physical (manual removal, mechanical removal, drying and burning, reduction of water nutrient level) and herbicidal control measures alone or in combination were employed. Even though the application of herbicide proved to be effective in controlling this aquatic weed at WSSF (Dula et al., 2008; Firehun and Yohannes, 2009) its use is greatly discouraged because of health and environmental concerns. Moreover, manual removal and burning of the weed has been employed alone on grazing and crop lands located at Koka, Alem Tena and Aba-Samuel which resulted in limited success (Table 2.6). With integrated use of physical and chemical control measure in reservoirs, irrigation supplies and drainage canals of WSSF, it was possible to achieve successful control (Taye et al., 2009). Hence, the rapid proliferation of water hyacinth in Lake Koka, Lake Ellen, and Aba-Samuel Dams (upstream water bodies) could be the result of absence of effective control measures and the wide-spread availability of nutrients in fresh water bodies. Yet, sustainability of the success achieved at WSSF is not guaranteed as the upstream water bodies are still infested with the weed and its extent of invasion increased over years.

\subsubsection{Impact of control measure: a case study of Wonji-Shoa sugar factory}

Water hyacinth was first reported on the irrigation and drainage structures of WSSF in 1996 (Firehun et al., 2007; Taye et al., 2009). The high nutrient inputs from sewerage, factory waste and flooding of additional inputs from the surrounding areas created ideal conditions for the proliferation of the weed mainly on reservoirs, irrigation supply and drainage canals. By the year 2006, it covered about 116.4 ha of water bodies (Firehun et al., 2007). An integrated (physical and chemical) control strategy had been exercised in 2006/07 (Dula et al., 2008) and reduced water hyacinth to a significant level $(>50 \%)$ of its original area. 
Table 2.6. Effect of the implemented management methods on percent weed control, weed count, fresh weight and flower number on selected water bodies.

\begin{tabular}{lrrrrr}
\hline & \multicolumn{6}{c}{ Management methods } \\
\cline { 2 - 6 } Parameters & A & B & C & D & E \\
\hline Percent weed control (\%) & 0.0 & $43.7^{*}$ & $57.5^{*}$ & $81.6^{* *}$ & $93.1^{* *}$ \\
Weed count (No. m ${ }^{-2}$ ) & 348.0 & $196.0^{* *}$ & $148.0^{* *}$ & $64.0^{* *}$ & $24.0^{* *}$ \\
Fresh weight $\left(\mathrm{g} \mathrm{m}^{-2}\right.$ ) & 560.0 & $470.0^{*}$ & $304.0^{* *}$ & $224.0^{* *}$ & $104.0^{* *}$ \\
Flower number (No.) & 96.0 & $56.0^{*}$ & $36.0^{* *}$ & $20.0^{* *}$ & $12.0^{* *}$ \\
\hline
\end{tabular}

Note: Two sample t-test assuming unequal variances was performed for physical control along with preventive measures [B], one time glyphosate application followed by physical control along with preventive measures [C], two times glyphosate application followed by physical control along with the preventive measures [D], and three times glyphosate application followed by physical control along with the preventive measures [E], against untreated check [A]; ${ }^{*}$ and ${ }^{* *}$ indicate significance at $5 \%$ and $1 \%$ probability level, respectively.

Table 2.7. Area of water bodies infested by water hyacinth, cost (Ethiopian Birr; average rate: US\$ $1=$ ETB 8,22) for its management and success rate per year at WSSF, Central Rift Valley, Ethiopia.

\begin{tabular}{ccccc}
\hline Year & $\begin{array}{c}\text { Area infested } \\
\text { (ha) }\end{array}$ & Cost (ETB) & $\begin{array}{c}\text { Success rate* } \\
\text { (ha of water bodies } \\
\text { cleared and/or } \\
\text { maintained) }\end{array}$ & Action taken \\
\hline $1999 / 2000$ & $<25$ & 13,500 & - & Physical control \\
$2000 / 2001$ & ND & 18,779 & - & Physical control \\
$2001 / 2002$ & $<35$ & 25,017 & -15 & Physical control \\
$2002 / 2003$ & $<50$ & 25,103 & -25 & Physical control \\
$2003 / 2004$ & 70 & 26,485 & -45 & Physical control \\
$2004 / 2005$ & 116 & 42,582 & -91 & Physical control \\
$2005 / 2006$ & 116 & 189,668 & 0 & Integrated management \\
$2006 / 2007$ & 66 & 392,966 & 50 & Integrated management \\
$2007 / 2008$ & 28 & 62,716 & 88 & Integrated management \\
$2008 / 2009$ & 10 & 9,579 & 106 & Integrated management \\
$2009 / 2010$ & 7 & 8,574 & 109 & Integrated management \\
$2010 / 2011$ & $<7$ & 7,890 & $>109$ & Integrated management \\
\hline Total cost & \multicolumn{4}{c}{} \\
\hline
\end{tabular}

* Success rate for the year 2002/03 and 2004/05 was calculated taking 1999/2000 as a base while for the remaining years taking $2004 / 05$ as a base data. 
Following this control strategy, relatively small cost of weed management was incurred and the water hyacinth infestation had been maintained at approximately $<7 \%$ in 2011. The initial investment of the control strategy has played a significant role in reducing the water hyacinth infestation and maintaining its subsequent costs at minimum level. Currently, WSSF incurs a constant cost year to year just to maintain the cleared water bodies and proper water flow of irrigation and drainage canals.

At WSSF, the cost of water hyacinth management varied from year to year (Table 2.7). From $1999 / 2000$ to $2005 / 06$ costs were increasing significantly together with the area of infestation. From 2006/07 to 2010/11 costs reduced significantly following the significant success rate in clearing and maintaining the water bodies. The low cost between $1999 / 2000$ to $2004 / 05$ corresponds with the period where only manual clearing and dredging of the weed were employed. During this period both the manual clearing and dredging of the weed had been employed mainly for canal restructuring purpose not as management of the weed. Hence, the control operations were performed at low efficiency and focussed on removal of the weed from the water bodies and left it on the edge of the irrigation structures and cost allocated was meant for canal maintenance instead of weed management.

The cost of management increased significantly from 2005/06 to 2006/07 which corresponds with WSSF's integrated management strategy employed on the different water bodies based on the level of infestation. The total investment of this control strategy, including the cost of conventional physical control mechanism, was ETB 822,859 from $1999 / 2000$ to $2010 / 2011$. The present investigation indicated that the investment made for integrated control strategy during the period 2005/06 to 2007/08 (ETB 645,350) resulted in a successful management of the weed. It effectively and significantly reduced the level of infestation from 116.4 ha to less than 7 ha and then maintained more than 88 ha of water bodies free of this weed over the past five years.

According to the assessment made in 2004/05 in the estate, it was noted that from the two highly infested water reservoirs a total of 393,660 to $2,945,160 \mathrm{~m}^{3}$ water was lost via transpiration (Firehun et al., 2007). This amount of water could irrigate an additional 31-233 ha of land in a given cropping season. The drainage system blockage by the weed which contributes for the rise of the groundwater table and flooding problems were prevalent in the sugar estate. With the implementation of integrated management strategy, it was possible to reinstate the two highly infested water bodies, ensure proper drainage of irrigation and waste water, which consequently helped to alleviate the detrimental effects of the weed in the factory. As explained by the effect of water loss, flooding, groundwater table rise and its associated cost of mitigation, the employed management strategy of water hyacinth in the factory delivered significant return and justified the investment. However, in order to ensure sustainability of the 
present success, it is vital to have effective management strategy on the site and the upstream water bodies.

\subsection{Conclusion}

Water hyacinth was introduced in the water bodies of the Rift Valley in the 1950s as an ornamental plant. After infesting Aba-Samuel Dam, it eventually spread in to Lake Koka, Lake Ellen, Koka Dam and Wonji site; where its proliferation was spectacular, resulting in an enormous socio-economic impact. Currently, the weed is distributed in the Rift Valley water bodies located in low, mid and high altitude. The low altitude water bodies infested by water hyacinth include Lake Abaya, Lake Koka, Koka Dam, irrigation and drainage structures along Awash River located at Koka and Awash. The mid and high altitude infested water bodies include the two lakes located in Alem Tena site (Lake Ellen and Lake Elltoke) and Aba-Samuel Dam, respectively. Extent of water hyacinth infestation showed the most massive coverage at Lake Koka, Lake Ellen, Aba-Samuel Dam and Koka Dam towards 2011. Univariate as well as PCA analysis indicated that the main factors representing the majority of correlations with water hyacinth coverage are associated with five factors (i.e., rainfall, $\mathrm{N}$ content, $\mathrm{P}$ content, wave action on the water bodies and depth of the water bodies).

The estimates of hyacinth mats show reductions in the extent of hyacinth coverage during the last three years at Wonji-Shoa. A case study on the impact of control measure indicated that following the implementation of integrated management strategies at WSSF, it was possible to maintain proper water flow in irrigation and drainage canals. However, in order to ensure sustainability of the present success, it is vital to have an effective management strategy on the site and the upstream water bodies.

\section{Acknowledgements}

The authors would like to thank EIAR-UNEP-GEF for funding as well as Ethiopian Sugar Corporation, for providing us with much needed logistical support. In particular we would like to thank Mr Ambachew Dametie, Mr Abera Tafesse, and Mr Abiy Negesse. 
CHAPTER 3

\section{Joint use of insects and fungal pathogens in the management of water hyacinth (Eichhornia crassipes): Perspectives for Ethiopia}

Y. Firehun, P.C. Struik, E.A. Lantinga and T. Taye (2013)

Journal of Aquatic Plant Management 51: 109-121 


\begin{abstract}
Water hyacinth [Eichhornia crassipes (Mart.) Solms] remains one of the worst aquatic weeds worldwide. Its presence in Ethiopia was officially reported in Koka Lake and Awash River about 60 years ago. Experiences worldwide indicate that the use of bioagents is the most economical and sustainable control measure for water hyacinth. In Ethiopia, the management of this invasive weed using bioagents is still in an experimental stage. However, the use of bioagents against water hyacinth at the national level has currently received attention, and researchers have become engaged in surveys and programmes to introduce and evaluate native, as well as classical, bioagents. The mottled water hyacinth weevil (Neochetina eichhorniae Warner) and the chevroned water hyacinth weevil (Neochetina bruchi Hustache) are the most successful bioagents released worldwide so far. A modelling tool, CLIMEX, has been applied to predict $N$. eichhorniae and $N$. bruchi potential distribution and adaptability in Ethiopia. Accordingly, the Ecoclimatic Index and Climate Matching results suggest that these weevils could be a potential bioagent for water hyacinth in Ethiopia. On the other hand, 25 fungal isolates were collected during the recent survey in addition to the known prevalence of the fungus Cercospora rodmanii Conway. This indicates the opportunity for the joint use of fungal pathogens and the water hyacinth weevils. In this chapter, the use of insects and pathogens, their host specificity and their herbivory/virulence effect, as well as recent advances in the use of those bioagents to manage water hyacinth are discussed.
\end{abstract}

Keywords: Classical bioagent, mycoherbicides, native bioagent 


\subsection{Introduction}

Water hyacinth [Eichhornia crassipes (Mart.) Solms] is one of the worst aquatic weeds in the world. It originates from the Amazon and has disseminated quickly in many tropical and sub-tropical countries of Latin America, the United States and the Caribbean, Africa, South-east Asia, and the Pacific region (Julien et al., 1999; Julien, 2001). Its erect, free-floating habit and showy flowers made it attractive for use in ornamental ponds and garden pools, which inevitably led to anthropogenic spread. Center et al. (2002) and Cilliers et al. (2003) reported that water hyacinth was spread around the world primarily by people and by shared watersheds. Similarly, in Ethiopia, the weed is believed to have been introduced by people for decorative purpose. Water hyacinth was officially reported in Ethiopia about 60 years ago in Koka Lake and the Awash River (Stroud, 1994). Infestations have now manifested on a large scale in many water bodies of Ethiopia, such as the Sobate, Baro, Gillo, and Pibor rivers, found in the Gambella area; the Abay River, just south of Lake Tana, Lake Abaya, and Lake Ellen; the Koka dam; and in reservoirs, irrigation supplies, and drainage structures of the Wonji-Shoa and Metahara sugar estates, located along the Awash River (Stroud, 1994; Rezene, 2005; Taye et al., 2009)

Biological control of water hyacinth, using natural enemies, has been reported to be the most economical and sustainable method of control because it persists with little ongoing cost and no negative environmental impacts (Julien et al., 1999). There are two approaches used in biological control: classical biological control and nonclassical biological control. Classical biological control involves the introduction of natural enemies from their native range into an exotic range where the host plant has become a weed. Non-classical biological control concentrates on the use of native, inundative (release of large numbers of the agent to control the target weed, e.g., mycoherbicides) or augmentative (Harley and Forno, 1992; Adkins, 1997; Auld, 1997) natural enemies. Water hyacinth is a primary target for classical biological control, in which natural enemies from the plant's center of origin are screened, reared, and released into the areas newly invaded by the target plant.

Insects and pathogens are known to have a controlling effect on water hyacinth. Research into the biological control of water hyacinth was initiated by the U.S. Department of Agriculture (USDA) in 1961, and to date six arthropods that attack water hyacinth in its region of origin have been released for biocontrol in a number of countries. The most successful of these arthropods are two species of Neochetina Hustache weevils (Julien, 2001): the mottled water hyacinth weevil (Neochetina eichhorniae Warner) and the chevroned water hyacinth weevil ( $N$. bruchi Hustache) (Coleoptera, Curculionidae). A recent study by the International Institute of Tropical 
Agriculture (Ibadan, Nigeria) estimated that biological control of water hyacinth through the introduction, mass rearing and releasing of $N$. eichhorniae and N. bruchi, would yield a benefit-cost ratio of $124: 1$ in the Republic of Benin during the next 20 year (De Groote et al., 2005). Moreover, several highly virulent pathogens of water hyacinth have been studied and are promising candidates for biocontrol (Charudattan, 2001a).

Combined use of biological control agents (bioagents) has been advocated as the best prospect for long-term management of aquatic weeds (Charudattan, 2001a, b; Evans and Reeder, 2001). In line with that, efforts are being made to assess the integration of insect pests and fungal pathogens for the management of water hyacinth (Moran, 2005, 2006; Martinez and Gomez, 2007). Similarly, research is being conducted to complement the effect of weevils with other arthropods in the management of water hyacinth (Coetzee et al., 2007).

Despite successes elsewhere with bioagents, combined and alone, in managing water hyacinth, biological control of water hyacinth has not yet been started in Ethiopia, and water hyacinth continues to cause serious problems. Thus, we reviewed the use of insects and pathogens, their host specificity, and their herbivory/virulence effect against water hyacinth, as well as recent advances in the use of those bioagents (insects and pathogens) for managing water hyacinth. The opportunities for extending the use of those bioagents in Ethiopia were evaluated for the sustainable management of water hyacinth in the country.

\subsection{Use of insects as bioagents of water hyacinth}

\subsubsection{Review on use of insects in water hyacinth management}

Surveys for natural enemies of water hyacinth for use as biological control agents began in 1962. The first survey was conducted in Uruguay, from 1962 to 1965. During that period, the water hyacinth stalk borer moth [Xubida (=Acigona) infusellus Walker (Lepidoptera: Pyralidae)]; two weevil species, N. eichhorniae and N. bruchi; the water hyacinth mite [Orthogalumna terebrantis Wallwork (Acarina: Galumnidae)]; and the water hyacinth grasshopper [Cornops aquaticum Bruner (Orthoptera: Acrididae, Leptysminae)] were recorded, among other species. The petiole-tunnelling moth, called the water hyacinth stem borer [Niphograpta (=Sameodes) albiguttalis Warren (Lepidoptera: Pyralidae)]; six species of petiole-boring flies [Thrypticus spp. Gerstaecker (Diptera: Dolichopodidae)]; and the water hyacinth mirid bug [Eccritotarsus catarinensis Carvalho (Heteroptera: Miridae)] were added to the list of biocontrol agents in 1968 surveys conducted in Guyana, Surinam, and Brazil (Center, 1994; Julien et al., 2001). In the early 1970s, the USDA and International Institute of 
Biological Control (now CABI Bioscience) released the weevils $N$. eichhorniae, $N$. bruchi, and later, the pyralid moth Niphograpta albiguttalis. Orthogalumna terebrantis and the stem-boring moth, the pickerelweed borer [Bellura densa Walker (Lepidoptera: Noctuidae)] were also recorded in surveys conducted in the United States in the 1960s. In 1989, the mirid E. catarinensis was collected in Brazil (Hill et al., 1999).

About 19 of 43 arthropod species have been identified as potential control agents because of the damage they cause or because of their narrow host range (Perkins, 1974). Cordo (1999) and Center et al. (2002) have listed these species according to their priorities for biological control. Accordingly, the arthropods were categorized into three priority groups.

The first priority group includes agents in use worldwide, such as $N$. eichhorniae, $N$. bruchi, N. albiguttalis, and $O$. terebrantis. The second priority group includes candidates recently released or under testing: E. catarinensis, X. infusellus, $C$. aquaticum, B. densa, paracles tenuis [Paracles (=Palustra) tenuis Berg (Lepidoptera: Arctiidae)], and Thrypticus spp. The third priority group, includes candidates that are poorly known or of questionable specificity (mostly with no recorded common names): a bombardier beetle [Brachinus Weber sp. (Coleoptera: Carabidae)], a water hyacinth moth [Argyractis subornata Hampson (Lepidoptera: Pyralidae)], a rootfeeding rice pest [Macrocephala acuminata Dallas (Heteroptera: Pentatomidae)], a planthopper [Taosa inexacta Walker (Homoptera: Dictyopharidae)], Argentine species of planthoppers [Megamelus electrae Muir and Megamelus scutellaris Berg (Homoptera: Delphacidae)], a stem miner [Eugaurax setigena Sabrosky (Diptera: Chloropidae)], a petiole-mining midge [Chironomus falvipilus Rempel (Diptera: Chironomidae)], a shore fly [Hydrellia sp. Robineau-Desvoidy (Diptera: Ephydridae)], and a mite [Flechtmannia eichhorniae Keifer (Acarina: Eriophyidae)].

The biology, host specificity, and potential for the management of water hyacinth for M. scutellaris have recently been better understood and (Sosa et al., 2004, 2005, 2007a, b; Tipping et al., 2010). In addition, those findings indicated that M. scutellaris was highly specific to water hyacinth and provided $70 \%$ biomass and $73 \%$ leaf reduction (Tipping et al., 2010). Hence, that bioagent would be better categorized as belonging to the second priority group. Table 3.1 lists potential insects being used or recently released for the management of water hyacinth and their types of damage.

Currently, biological control of water hyacinth in different parts of the world relies on two weevil species ( $N$. eichhorniae and $N$. bruchi), the pyralid moth ( $N$. albiguttalis), the mite $O$. terebrantis, and the mired E. catarinensis (Julien and Griffiths, 1998; Julien et al., 2001; Coetzee et al., 2005). These agents reduced water hyacinth growth and densities, plant stature, and possibly, seed production (Center and 


\section{Chapter 3}

Durden, 1986; Center, 1994; Center et al., 1990, 1999a, b; Julien et al., 1999; Coetzee et al., 2005). Recent research has targeted C. aquaticum (Bownes et al., 2010a, b), M. scutellaris (Sosa et al., 2005, 2007a, b; Tipping et al., 2010), and other potential candidate arthropods. Therefore, details of these bioagents are reviewed below.

\section{Neochetina eichhorniae and N. bruchi:}

Neochetina eichhorniae and N. bruchi have been released on water hyacinth in 30 and 27 countries, respectively (Center et al., 2002). Both have been subjected to extensive screening. They have been tested against 274 plant species in 77 families worldwide (Julien et al., 1999). In Africa, these weevils were released in Benin, Burkina Fasso, Congo Cote d'Ivoire, Egypt, Ghana, Kenya, Malawi, Mali, Mozambique, Niger, Nigeria, Rwanda, South Africa, Sudan, Tanzania, Togo, Uganda, Zambia, and Zimbabwe (Cillers et al., 2003). Neochetina eichhorniae and N. bruchi are the most successful bioagents used for the control of water hyacinth. In East Africa (Uganda), the two weevils, at five year after release in Lake Victoria, experienced a rapid buildup in population (average, 17-25 weevils plant ${ }^{-1}$ ), which reduced weed biomass about $80 \%$ (Ogwang and Molo, 2004). Those results were later repeated on the Kenyan and Tanzanian shores (Mallya et al., 2001; Ochiel et al., 2001). Similarly, in West Africa (Benin), the weevils reduced the water hyacinth cover from 100 to $5 \%$ within 8 years (Ajuonu et al., 2003). In northern Africa (Egypt), N. eichhorniae and N. bruchi were released in August 2000 on two lakes. By July 2002, water hyacinth on Lake Edko was reduced by $90 \%$ (Cillers et al., 2003). That success in Africa was reaffirmed in Mexico, where a $20-80 \%$ reduction of the water hyacinth population occurred within 2-3 year after release (Aguilar et al., 2003).

\section{Niphograpta albiguttalis:}

Julien and Griffiths (1998) reported that $N$. albiguttalis had been released in more than 10 countries; however, its establishment has been confirmed only in Australia, South Africa, the Sudan, the United States, Thailand, and Malaysia.

\section{Orthogalumna terebrantis:}

Although the $O$. terebrantis mite has infested various populations of water hyacinth for considerable periods, it has not contributed to control of the weed (Julien, 2001). The mite was first released in Zambia in 1971 and then, in India, during 1986. It is present in Mexico, Cuba, Jamaica, the southern United States, and South America and has spread from Zambia to Malawi, Mozambique, South Africa, and Zimbabwe (Julien and Griffiths, 1998). 
Table 3.1. Potential arthropod in use or on process for the management of water hyacinth.

\begin{tabular}{|c|c|c|}
\hline Species & Type of damage & Status \\
\hline $\begin{array}{l}\text { N. eichhorniae Warner } \\
\text { (Col.: Curculionidae) }\end{array}$ & $\begin{array}{l}\text { Adults feed on foliage } \\
\text { and petioles, larvae } \\
\text { tunnel in petioles, } \\
\text { stolons and crown }\end{array}$ & $\begin{array}{l}\text { In use in North America, Australia, } \\
\text { Africa, and Asia (Julien and Griffiths, } \\
\text { 1998) }\end{array}$ \\
\hline $\begin{array}{l}\text { N. brunchi Hustache (Col.: } \\
\text { Curculionidae) }\end{array}$ & $\begin{array}{l}\text { Adults feed on foliage } \\
\text { and petioles, larvae } \\
\text { tunnel in petioles, } \\
\text { stolons and crown }\end{array}$ & $\begin{array}{l}\text { In use in North America, Australia, } \\
\text { Africa, and Asia (Julien and Griffiths, } \\
\text { 1998) }\end{array}$ \\
\hline $\begin{array}{l}\text { N. albiguttalis (Warren) } \\
\text { (Lep.: Pyralidae) }\end{array}$ & $\begin{array}{l}\text { Larvae tunnel in } \\
\text { petioles and buds }\end{array}$ & $\begin{array}{l}\text { In use in North America, Australia, } \\
\text { Africa, and Asia (Julien and Griffiths, } \\
\text { 1998) }\end{array}$ \\
\hline $\begin{array}{l}\text { O. terebrantis Wallwork } \\
\text { (Acarina: Galumnidae) }\end{array}$ & $\begin{array}{l}\text { Immature tunnel in } \\
\text { laminae }\end{array}$ & $\begin{array}{l}\text { In use in North America and Africa } \\
\text { (Julien and Griffiths, 1998) }\end{array}$ \\
\hline $\begin{array}{l}\text { E. catarinensis (Carvalho) } \\
\text { (Heter.: Miridae) }\end{array}$ & $\begin{array}{l}\text { Nymph and adult feed } \\
\text { on leaves }\end{array}$ & $\begin{array}{l}\text { Released in Zimbabwe, Zambia, } \\
\text { Malawi, Benin, South Africa and } \\
\text { China, however, established in Malawi } \\
\text { and South Africa (Coetzee et al., 2005) }\end{array}$ \\
\hline $\begin{array}{l}\text { X. infusellus (Walker) } \\
\text { (Lep.: Pyralidae) }\end{array}$ & $\begin{array}{l}\text { Larvae tunnel in } \\
\text { laminae and petioles }\end{array}$ & $\begin{array}{l}\text { Released in Australia, Thailand and } \\
\text { Papua New Guinea (Julien et al., } \\
\text { 2001). Recent study indicated that this } \\
\text { agent can be used in areas where } \\
\text { Pickerweed is not present or considered } \\
\text { important relative to water hyacinth } \\
\text { problem (Stanley et al., 2007) }\end{array}$ \\
\hline $\begin{array}{l}\text { C. aquaticum (Bruner) } \\
\text { (Orth.: Acrididae, } \\
\text { Leptysminae) }\end{array}$ & $\begin{array}{l}\text { Nymph and adult feed } \\
\text { on leaves }\end{array}$ & $\begin{array}{l}\text { In South Africa a release permit } \\
\text { granted in } 2007 \text {, besides, potential } \\
\text { impact assessment result showed this } \\
\text { insect could contribute to a reduction } \\
\text { and the density and spread of water } \\
\text { hyacinth (Bownes et al., 2010a, b) }\end{array}$ \\
\hline $\begin{array}{l}\text { B. densa (Walker) (Lep.: } \\
\text { Noctuidae) }\end{array}$ & $\begin{array}{l}\text { Larvae tunnel in } \\
\text { petioles and buds }\end{array}$ & $\begin{array}{l}\text { Current study confirmed that } B \text {. densa } \\
\text { prefers plants in the Pontederiaceae } \\
\text { such as Colocasia esculenta. Hence, it } \\
\text { is recommend to be used within North } \\
\text { America only (Center and Hill, 2002) }\end{array}$ \\
\hline $\begin{array}{l}\text { P. tenuis (Berg) (Lep.: } \\
\text { Arctiidae) }\end{array}$ & $\begin{array}{l}\text { Larvae and adult feed } \\
\text { on leaves }\end{array}$ & $\begin{array}{l}\text { Polyphagous in laboratory testing. It is } \\
\text { developed readily on P. rotundifolia, } \\
\text { Alternanthera Canna, Limnobium, } \\
\text { Sagittaria. Rejected for further studies } \\
\text { (Cordo, 1999) }\end{array}$ \\
\hline $\begin{array}{l}\text { Thrypticus spp. -seven } \\
\text { species- (Dip.: } \\
\text { Dolichopodidae) }\end{array}$ & $\begin{array}{l}\text { Larvae tunnel in } \\
\text { petioles }\end{array}$ & $\begin{array}{l}\text { T. truncatus and } T \text {. saggittatus } \\
\text { reproduce on water hyacinth and are } \\
\text { host specific (Hernandez, 2008). Its } \\
\text { effect on the host is under } \\
\text { investigation. A number of potential } \\
\text { fungal pathogens found in association } \\
\text { with the larvae of these two flies } \\
\text { (Hernandez et al., 2007) }\end{array}$ \\
\hline $\begin{array}{l}\text { M. scutellaris Berg (Hom.: } \\
\text { Delphacidae) }\end{array}$ & $\begin{array}{l}\text { Nymph and adult feed } \\
\text { on laminae and } \\
\text { petioles }\end{array}$ & $\begin{array}{l}\text { In America a release permit granted in } \\
2010 \text { and release has been conducted } \\
\text { in selected locations (Tipping et al., } \\
2010 \text { ) }\end{array}$ \\
\hline
\end{tabular}




\section{Chapter 3}

\section{Eccritotarsus catarinensis:}

The mirid E. catarinensis has been released in South Africa at about 18 sites since 1996 (Hill et al., 1999) and has established at 15 sites. Subsequent evaluations have demonstrated that it affects water hyacinth growth (Coetzee et al., 2007) and competitive ability (Coetzee et al., 2005; Ajuonu et al., 2009), by reducing the plant's overall vigour. Eccritotarsus catarinensis has also been released in Zimbabwe, Zambia, Malawi, Benin, and China but only established in Malawi (Coetzee et al., 2009a). It was, however, rejected for release in Australia because of possible damage to populations of native monochoria [Monochoria vaginalis (Brum. f.) Kunth] (Stanley and Julien, 1999). In South Africa, feeding, oviposition, and nymphal development of the mirid were recorded on pickerelweed (Pontederia cordata L.), an important aquatic plant in North America but a potential weed in South Africa. The release of this agent in the field confirmed that pickerelweed was not part of the mirid's realized host range. Eccritotarsus catarinensis is emerging as an effective agent in areas of medium to low nutrient status with a warm climate and would be considered for release in other areas (Coetzee et al., 2009a).

The present review of potential insect bioagents of water hyacinth indicated that, although a large number of arthropods have been identified and found in association with water hyacinth, only six are in use or confirmed for release. There is a clear and distinctive difference in the success of these agents in different parts of the world.

Among the six arthropods, the two weevils exhibited the best success in the tropics, especially in the eastern and western parts of Africa, where great success was recorded within 3-10 year. Besides the two weevils, success was recorded with the use of the moth $N$. albiguttalis. The success recorded from these well-established bioagents was unsatisfactory in temperate regions. Accordingly, researchers in South Africa and the United States have made efforts toward evaluating other potential herbivores, such as E. catarinensis and C. aquaticum (Coetzee et al., 2005; Bownes et al., 2010b). Consequently, great achievements have been realized with the use of the mirid in South Africa, which may promote its use in the United States (Coetzee et al., 2009a).

The relatively stable performance of the two weevils in tropical regions, such as Papua New Guinea (Julien and Orapa, 1999), Benin (Ajuonu et al., 2003), on Lake Victoria in Uganda, and in Tanzania and Kenya (Mallya et al., 2001; Ochiel et al., 2001; Ogwang and Molo, 2004) indicates a potential for use of these weevils in Ethiopia. Williamson (1996) reported that, when deliberate introductions of natural enemies are made for biological control, they should be species or strains from climatically matched area. There should be a pre-release assessment of the weevil efficacy and adaptability, and a confirmatory host specificity study should be 
conducted on the indigenous and economical crops of the country. Success of biological control agents appears to depend on their abundance, distribution, and per capita damage (McClay and Balciunas, 2005). Unfortunately, there is currently no reliable approach for accurately predicting post-release abundance of a species before release. However, several methods have been developed to estimate distribution range and per capita damage of the biological control agent. Modelling tools, such as CLIMEX, enable us to predict an organism's potential distribution in the area of introduction (Sutherst et al., 2000). Experimental studies in quarantine or at rearing sites enable us to test plant responses to herbivory and to quantify the effect of potential biological control agents before their release. Accordingly, climate matching between Ethiopia and those tropical regions in Africa where the weevils were successfully used, such as Uganda, Sudan, Benin, and others, allowed the development of an index of similarity. The index was generated based on maximum and minimum temperature, rainfall, and rainfall distribution. Details of the model result are presented in Section 3.2.3.

\subsubsection{Herbivory effect of the Neochetina weevils}

As observed in the above section, the water hyacinth weevils are being used in different parts of the world with variable success. However, herbivory effects of these bioagents vary when used alone and in combination with one another. Center et al. (2005) reported that $N$. eichhorniae and $N$. bruchi exhibited different herbivory effects on water hyacinth biomass and ramet development, but when the plant was in flower, both species performed similarly. Biomass yield declined because of herbivory, with $N$. bruchi inducing greater reductions than $N$. eichhorniae did, and both weevil species restricted flowering by similar amounts. Herbivory by the two water hyacinth weevils decreased water hyacinth competitive performance by $98 \%$ at 10 weeks. In that finding, the performance of $N$. bruchi looks better than that of $N$. eichhorniae alone and equivalent to it when combined with $N$. eichhorniae. However, because the experiment was conducted under high-nutrient conditions, the similarity of the herbivory effect exhibited by $N$. bruchi alone and when combined with $N$. eichhorniae could have resulted from the positive effect of nutrients to N. bruchi. Moreover, success was also achieved with the use of both species where $N$. eichhorniae establishment was relatively higher (Van Thielen et al., 1994; Center et al., 1999a; Ajuonu et al., 2003). The combined use of the two weevils has better herbivory impacts on water hyacinth than does either one alone. The relative establishment of the weevils' density depends on plant, nutrient, and herbivory interaction. In addition, it suggests a synergy potential between the two weevils and other bioagents (insects or pathogens) in the management of water hyacinth. 


\subsubsection{Opportunities to use the Neochetina weevils in Ethiopia: Prediction using the CLIMEX mode}

The 'Match Climate' function of the computer program CLIMEX compares long-term meteorological data for each of the selected 'Away' locations, with the climate of the 'Home' locations used to determine the nominal level of similarity between the locations, as suggested by Sutherst et al. (2004). Overseas tropical locations, where good control of water hyacinth using the two water hyacinth weevils has occurred, were climatically matched with Africa (Ethiopia) locations (Figure 3.1). Those climatic matches showed that, at a similarity match of $0.7-1.0$, large areas of the Rift Valley of Ethiopia were similar to Bangalore (India), Khartoum (Sudan), Kampala (Uganda), Kisumu (Kenya), Cotonou (Benin), and some other locations in West Africa. This indicates that the prevailing climatic conditions in the Rift Valley of Ethiopia could be a suitable area for the weevils. Climate modelling was also used to determine whether climate would be a limiting factor for establishment and spread of water hyacinth weevils in Ethiopia. Based on the known distribution of the two Neochetina weevils in the native range (Figure 3.2A) and data about their biology, the potential geographic distribution was analysed in relation to climate. The results indicated that the water hyacinth weevils could permanently inhabit western and eastern parts of Africa (Figure 3.2B). The hot and wet areas in Ethiopia would be the most suitable. This climate-matching approach provides confidence that the projected distribution of the weevils in Ethiopia would be realistic and robust. Among the different parameters, the CLIMEX moisture parameter was not computed for this analysis because the natural host-plant, water hyacinth, requires standing water for its growth and development. In addition, the present analysis pointed out that stress at extreme cold and hot temperatures has affected the adaptability and survival of the weevils. In agreement with this, DeLoach and Cordo (1976b) and Julien et al. (2001) reported that the developmental period required by the two Neochetina weevils varied from country to country and from region to region depending on the prevailing climatic conditions. Data on the developmental threshold and degree-day requirements (CLIMEX PDD parameter) indicates that the two weevils would complete a number of generations per year $(>4.5)$. In agreement with that, Coetzee et al. (2007) reported successful establishment of the agents if the bioagent had $>1$ generation year ${ }^{-1}$.

On the other hand, prediction of the weevils' distribution or adaptability in scenarios for climate change in Africa by $+3{ }^{\circ} \mathrm{C}$ rise in temperature resulted in an increase in the potential range in northern and eastern parts of Ethiopia. A species climate-response model, based on the Ecoclimatic Index (EI) and results from Climate Matching suggested that the two known water hyacinth weevils could be valuable bioagents of water hyacinth in Ethiopia. The success achieved in the western and 

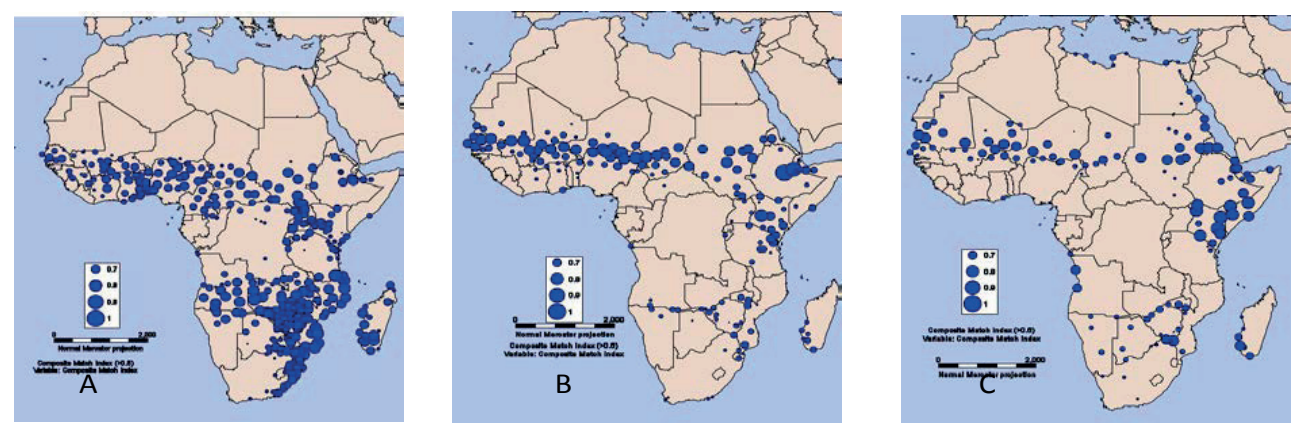

Figure 3.1. Climate match between (A) Bangalore and Africa, (B) Khartum and Africa, (C) Kampala and Africa using the 'Match Climates' function at $60-100 \%$ levels of similarity.

eastern part of Africa with the use of the two weevils indicates a good potential for the use of those agents in Ethiopia. The other important factor that could influence the performance of Neochetina weevils against water hyacinth relates to their sensitivity to low plant quality, as suggested by various authors (Wright and Stegeman, 1999; Center et al., 2002, 2005; Moran, 2006). However, plant-quality analysis indicated that most of water hyacinth prone areas of Ethiopia had adequate nutrient levels for growth and development of water hyacinth (Y. Firehun, unpublished data) thereby indicating plant quality would not be a limiting factor for establishment of the bioagents.
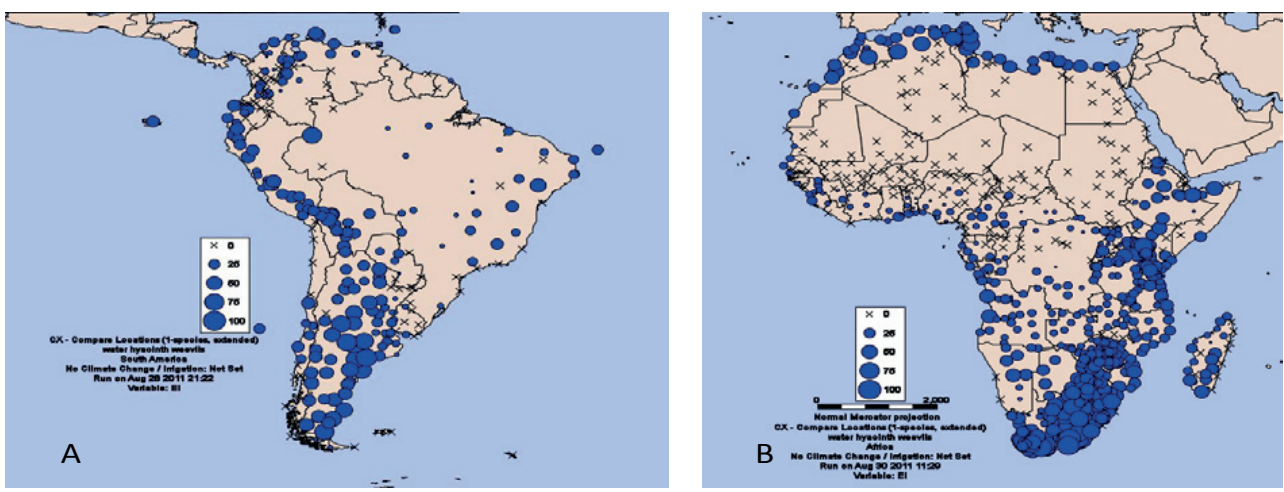

Figure 3.2. The known and predicted geographic distribution of Neochetina weevils in South America (A) and Africa (B) based on positive values of Ecoclimatic Index (EI). Locations marked with a cross have EI value of zero (B). The climatic favourableness of each location is proportional to the area of the circle. 


\subsection{Pathogens as biocontrol strategy}

\subsubsection{Review of fungal pathogens isolated from water hyacinth}

Biological control of weeds using plant pathogens has gained acceptance as a practical, safe, and environmentally beneficial weed-management method applicable to agro-ecosystems (Charudattan, 2001b). Use of plant pathogens has been shown to be highly effective against water hyacinth under experimental conditions (Shabana, 1997; Shabana et al., 1997). The fungal pathogen Cercospora piaropi Tharp. has been extensively studied (Freeman and Charudattan, 1984; Charudattan et al., 1985) and was patented by the University of Florida (Conway et al., 1978). It has been released in South Africa as classical biocontrol agent for water hyacinth (Morris et al., 1999). Worldwide, several efforts have been made to assess pathogens found in association with water hyacinth, and some of them have been evaluated and/or in use either as classical or inundative biological control agents (Charudattan, 2001a).

In Florida, during a 1973 survey, 30 species of fungi were found in association with water hyacinth (Conway et al., 1974). Among those species, Acremonium zonatum (Sawada) W. Gams, Bipolaris stenospila (Drechsler) Shoemaker, and C. piaropi were found to be pathogenic to the weed (Conway et al., 1974; Conway, 1976a, b). In a survey conducted in Sri Lanka, 15 fungal pathogens were reported to have co-evolved with water hyacinth (Hettiarachchi et al., 1983). Among those, Myrothecium roridum Tode, C. piaropi, Curvularia tuberculata B.L. Jain, Septofusidium elegantulum (Pidopl.) W. Gams, and Phaeotrichoconis crotalariae (M.A. Salam \& P.N. Rao) Subram. were capable of producing leaf spots on healthy water hyacinth leaves. For the last three species, this phenomenon was recorded for the first time.

Similarly, in Sudan, 21 fungal and three bacterial pathogens were isolated, of which Phoma sorghina (Sacc.) Borema, Dorenb., \& Kesteren, and Bacillus Fischer sp. were reported for the first time as potential pathogens of water hyacinth (Abdelrahim and Tawfig, 1984). Martinez and Charudattan (1998) reported that 17 native fungal genera were prevalent in Mexico, and A. zonatum, Alternaria Nees sp., C. piaropi, Fusarium Link sp., and Verticillium Nees sp. were highly damaging to water hyacinth. Evans and Reeder (2001) undertook a survey of fungal pathogens of water hyacinth in the Upper Amazon Basin of Peru and Ecuador. The results indicated that there were many mycobiota associated with water hyacinth in the Upper Amazon Basin, contrary to the findings of Barreto and Evans (1996). However, among the potential fungal pathogens reported to have excellent pathogenicity in water hyacinth, Alternaria eichhorniae Nag Raj \& Ponnappa, A. zonatum, and C. piaropi were not isolated (Evans and Reeder, 2001). In India (Kerala), Praveena and Naseema (2004) reported 21 fungal pathogens in association with water hyacinth, of which 17 were pathogenic. Moreover, among 
the pathogenic fungi, Myrothecium advena Sacc. was a new report for water hyacinth.

In Egypt, El-Morsy (2004) reported 22 fungal isolates from water hyacinth of which Alternaria alternate Nag Raj \& Ponnappa, Drechslera hawaiiensis (Bugnic.) Subram. \& B.L. Jain, Drechslera australiensis (Bugnic.) Subram. \& B.L. Jain, Drechslera halodes (Drechsler) Subram. \& B.L. Jain, Rhizoctonia solani J.G. Kuhn, and Ulocladium atrum Preuss were pathogenic. From these, D. hawaiiensis and U. atrum were isolated from water hyacinth for the first time.

In China, from a survey conducted in 2003 and 2004, nine pathogenic fungi of water hyacinth were isolated (Ding et al., 2008). Among them, two pathogens were reported to have the potential as biocontrol agents for the management of water hyacinth. In general, more than 90 plant pathogens co-evolved with water hyacinth, and several highly virulent fungal pathogens are known to cause diseases of water hyacinth. Table 3.2 provides a list of mycobiota recorded on water hyacinth in different parts of the world.

Table 3.2. Mycobiota recorded on Eichhornia crassipes, worldwide (amended from Evans and Reeder, 2001).

\begin{tabular}{|c|c|}
\hline Fungi & Distribution \\
\hline \multicolumn{2}{|l|}{ Ascomycotina and Deutromycotina } \\
\hline Acremoniella sp. & Peru \\
\hline Acremonium charticola (Lindau) Gams & Egypt \\
\hline $\begin{array}{l}\text { Acremonium crotocigenum (Schol-Schwarz) W. } \\
\text { Gams }\end{array}$ & Australia (IMI $288071^{\mathrm{a}}$ ) \\
\hline $\begin{array}{l}\text { Acremonium implicatum (Gilman \& Abbott) W. } \\
\text { Gams }\end{array}$ & Australia (IMI 271067) \\
\hline $\begin{array}{l}\text { Acremonium sclerotigenum (F. \& R. Moreau ex } \\
\text { Valenta) W. Gams }\end{array}$ & Sudan (IMI 284343) \\
\hline Acremonium strictum W. Gams & Australia (IMI 288318, 288319) \\
\hline Acremonium zonatum (Sawada) W. Gams & $\begin{array}{l}\text { Australia, India, Pakistan, Panama, USA, } \\
\text { Sudan, Mexico, Nigeria (IMI 394934) }\end{array}$ \\
\hline Acremonium spp. & Peru \\
\hline Alternaria sp. & Mexico, China \\
\hline Alternaria alternata (Fr.) Keissler & Egypt \\
\hline Alternaria eichhorniae Nag Raj \& Ponnappa & $\begin{array}{l}\text { Egypt, India, Thailand, USA, Kenya, } \\
\text { Ghana, South Africa, Zimbabwe }\end{array}$ \\
\hline Alternaria tenuissima (Nees ex Fr.) Wiltshire & Hong Kong \\
\hline Aspergillus carneus (Van Tiegh) Bloohwitz & Egypt \\
\hline Aspergillus niger VanTiegh & Egypt \\
\hline Aspergillus sulphureus Fres. & Egypt \\
\hline Asteroma sp. & Peru \\
\hline Bipolaris urochloae (Putterill) Shoemaker & Egypt (IMI 324728) \\
\hline
\end{tabular}




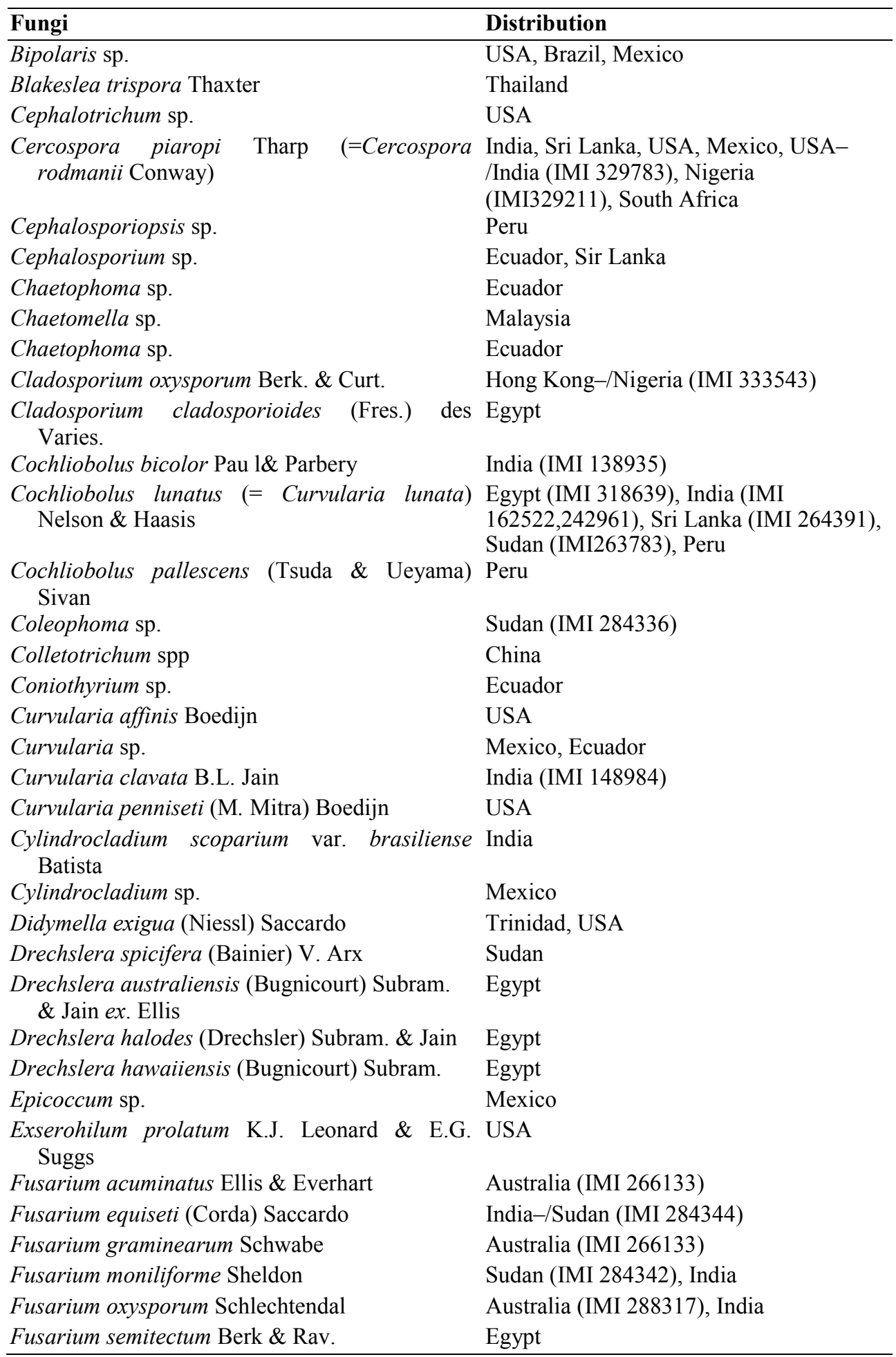




\begin{tabular}{|c|c|}
\hline Fungi & Distribution \\
\hline Fusarium solani (Martin) Saccardo & Australia (IMI 270062) \\
\hline Fusarium sulphureum Schlechtendal & India (IMI 297053) \\
\hline Fusarium pallidoroseum (Cooke) Sacc. & India \\
\hline Fusarium poae (Peck) Wollenw. & Peru \\
\hline $\begin{array}{l}\text { Fusarium sacchari (E.J. Butler \& Hafiz Kahn) } \\
\text { W. Gams. }\end{array}$ & Peru \\
\hline Fusarium sp. & Peru, Ecuador, Mexico \\
\hline Fusidium sp. & South Africa (IMI 318345 \\
\hline Gliocladium roseum Bainier & Australia (IMI 278745), Ecuador \\
\hline Glomerella sp. & Ecuador \\
\hline $\begin{array}{l}\text { Glomerella cingulata (Stonem) Spauld \& } \\
\text { Schrenk }\end{array}$ & Sri Lanka (IMI 264392), Brazil \\
\hline Helminthosporium sp. & Malaysia, India \\
\hline Hyphomycete spp & Peru, Ecuador \\
\hline Idriella $\mathrm{sp}$. & Peru \\
\hline $\begin{array}{l}\text { Leptosphaeria eichhorniae Gonzales Fragoso \& } \\
\text { Ciferri }\end{array}$ & Dominican Rep., Panama \\
\hline Leptosphaeria sp. & Peru \\
\hline Leptosphaerulina sp. & USA \\
\hline Memnoniella subsimplex (Cooke) Deighton & USA \\
\hline Monosporium eichhorniae Sawada & Taiwan \\
\hline Monilia sp. & Mexico \\
\hline Mycosphaerella tassiana (De Notaris) Johanson & USA \\
\hline Mycosphaerella sp. & Peru \\
\hline Myrothecium roridum Tode ex Fr. & $\begin{array}{l}\text { India, Philippines Thailand-/Burma } \\
\text { (IMI79771), Malaysia (IMI 277583), } \\
\text { Nigeria }\end{array}$ \\
\hline Myrothecium advena & India \\
\hline $\begin{array}{l}\text { Myrothecium verrucaria (Alb. \& Schwein.) } \\
\text { Ditmar }\end{array}$ & Peru \\
\hline Myrothecium sp. & Brazil \\
\hline Nigrospora sp & Mexico \\
\hline Penicillium chrysogenum Thom & Egypt \\
\hline Penicillium purpurogenum Stoll. & Egypt \\
\hline Periconia $\mathrm{sp}$ & Mexico \\
\hline Pestalotiopsis adusta (Ellis \& Everhard) Steyaert & Taiwan-/Hong Kong (IMI 119544) \\
\hline Pestalotiopsis palmarum (Cooke) Steyaert & India (IMI 148983) \\
\hline Phaeoseptoria sp. & Peru \\
\hline Pestalotia $\mathrm{sp}$ & Mexico, India \\
\hline Phoma chrysanthemicola Hollós & Peru \\
\hline Phoma leveillei Boerema. \& Bollen & Ecuador \\
\hline Phoma section Peyronellaea (Goid. ex Togliani) & Peru \\
\hline Phoma sorghina (Saccardo) Boerema et al. & $\begin{array}{l}\text { Sudan-/Australia (IMI 288313, } \\
\text { 288311,288312, 288315, 333325) }\end{array}$ \\
\hline
\end{tabular}




\begin{tabular}{|c|c|}
\hline Fungi & Distribution \\
\hline Phoma sp. & USA \\
\hline Phyllosticta sp. & Nigeria (IMI 327627, 327628) \\
\hline Pseudocercosporella sp. & Peru \\
\hline Sarocladium sp. & Peru \\
\hline Scopulariopsis brevicaulis (Sacc.) Bain. & Egypt \\
\hline Stauronema sp & Peru \\
\hline Stachybotrys chartarum (Ehrenb. Ex Link) & Egypt \\
\hline Spegazzinia tessarthra (Berk. \& Curt.) Saccardo & Sudan 284335 \\
\hline Stemphylium vesicarium (Wallroth) E. Simmons & USA \\
\hline Stemphylium sp. & Mexico \\
\hline Ulocladium atrum Preuss & Egypt \\
\hline Verticillium sp. & Egypt, Mexico \\
\hline \multicolumn{2}{|l|}{ Basidiomycotina } \\
\hline Basidiomycete spp. & Peru, Ecuador \\
\hline Basipetospora sp. & Mexico \\
\hline Blastomyces sp. & Mexico \\
\hline Doassansia eichhorniae Ciferri & Dominican Rep. \\
\hline Marasmiellus inoderma (Berk.) Singer & India \\
\hline $\begin{array}{l}\text { Mycoleptodiscus terrestris (J.W. Gerdermann) } \\
\text { Ostazeki }\end{array}$ & USA \\
\hline Rhizoctonia oryzae-sativae (Sawada) Mordue & Australia (IMI 289087) \\
\hline Rhizoctonia solani Kuhn & India, Panama, Thailand and USA \\
\hline Rhizoctonia sp. & India, USA \\
\hline Thanatephorus cucumeris (Frank) Donk & China, Taiwan-/India (IMI 3075) \\
\hline $\begin{array}{c}\text { Tulasnella grisea (Raciborski) Saccardo \& } \\
\text { Sydow }\end{array}$ & Indonesia (Java) \\
\hline Uredo eichhorniae Gonzales Fragoso \& Ciferri & Argentina, Brazil, Dominican Rep. \\
\hline $\begin{array}{l}\text { Chromista } \\
\text { Pythium sp. }\end{array}$ & USA \\
\hline
\end{tabular}

\subsubsection{Potential fungal pathogens and their host range: Comparative analysis}

Several fungal pathogens have been reported to attack water hyacinth in various parts of the world. Among the known pathogens, A. zonatum, A. alternata (Fr.) Keissl., A. eichhorniae, Bipolaris spp., D. spicifera (Bainier) Subram., F. chlamydosporum Wollenw. \& Reinking, F. pallidoroseum (Cooke) Sacc., F. equiseti (Corda) Sacc., Helminthosporium Link spp., C. piaropi, M. roridum, M. advena, R. solani, and $U$. eichhorniae Gonz. Frag. \& Cif. have been tested and confirmed to be highly virulent pathogens (Table 3.3). Of these, A. zonatum, A. alternata, A. eichhorniae, C. piaropi, $M$. roridum, and $M$. advena have been studied intensively as biocontrol agents and have been shown to be effective under experimental conditions (Shabana et al., 1995a, 
b, 1997, 2000; Charudattan, 2001a, b; Martinez and Gutierrez, 2001; Mohan et al., 2003; Praveena and Naseema, 2004). Details about the distribution, pathogenicity, and host specificity as well as their potential as biocontrol agent of water hyacinth for the selected pathogens are reviewed below.

Acremonium zonatum: Reports indicate that A. zonatum is prevalent in Australia, the United States, the Sudan, South Africa, Nigeria, many countries of Asia, Central America, and South America (Abdelrahim and Tawfig, 1984; Charudattan, 1990, 1996, 2001a; Morris et al., 1999). Among those countries, pathogens isolated from the Sudan, Nigeria, and Mexico showed highly virulent reaction against water hyacinth (Abdelrahim and Tawfig, 1984; Martinez and Charudattan, 1998; Okunowo et al.,

Table 3.3. Potential fungal pathogens of water hyacinth.

\begin{tabular}{|c|c|c|}
\hline Pathogen & Country & Reference \\
\hline A. zonatum & $\begin{array}{l}\text { Mexico, Sudan, Australia, } \\
\text { South Africa, Nigeria }\end{array}$ & $\begin{array}{l}\text { Galbraith, 1987; Abdelrahim and } \\
\text { Tawfig, 1984; Martinez and } \\
\text { Charudattan, 1998; Morris et al., 1999; } \\
\text { Okunowo et al., 2008 }\end{array}$ \\
\hline A. alternata & Egypt, India & $\begin{array}{l}\text { Elwakil et al., 1990; Shabana et al., } \\
\text { 1995a,b,1997; Mohan Babu et al., 2002, } \\
\text { 2003; El-Morsy, 2004; Ray, } 2006\end{array}$ \\
\hline A. eichhorniae & $\begin{array}{l}\text { Egypt, South Africa, India, } \\
\text { Bangladesh, Indonesia, } \\
\text { Thailand, }\end{array}$ & $\begin{array}{l}\text { Nag Raj and Ponnappa, 1970; } \\
\text { Charudattan, 1973; Mangoendihardjo et } \\
\text { al., 1978; Badur-ud-Din, 1978; } \\
\text { Rakvidhyasastra et al., 1978; Shabana et } \\
\text { al., 1995a,b,1997; Morris et al., } 1999\end{array}$ \\
\hline Bipolaris sp. & Dominican Republic & Charudattan, 1990, 1996 \\
\hline C. piaropi & $\begin{array}{l}\text { Mexico, South Africa, } \\
\text { Brazil, USA, Zambia, } \\
\text { Venezuela }\end{array}$ & $\begin{array}{l}\text { Martinez and Charudattan, 1998; } \\
\text { Charudattan, 2001a; Julien and Griffiths, } \\
\text { 1998; Hill and Coetzee, } 2008\end{array}$ \\
\hline D. specifera & Sudan & Abdelrahim and Tawfig, 1984 \\
\hline F. chlamydosporium & India & Charudattan, 1990; Aneja et al., 1993 \\
\hline F. equistee & Sudan & Abdelrahim and Tawfig, 1984 \\
\hline F. pallidoroseum & India & Praveena and Naseema, 2004 \\
\hline M. advena & India & Praveena and Naseema, 2004 \\
\hline M. roridum & $\begin{array}{l}\text { Sir Lanka, India, Malaysia, } \\
\text { Mexico, Nigeria }\end{array}$ & $\begin{array}{l}\text { Hettiarachchi et al., 1983; Charudattan, } \\
\text { 2001a; Okunowo et al., } 2008\end{array}$ \\
\hline R. solani & $\begin{array}{l}\text { USA, Brazil, India, } \\
\text { Mexico, Panama, Puerto } \\
\text { Rico, Malaysia, Indonesia }\end{array}$ & $\begin{array}{l}\text { Charudattan, 2001a; Praveena and } \\
\text { Naseema, } 2004\end{array}$ \\
\hline U. eichhorniae & South America & Charudattan, 1996, 2001a \\
\hline Verticillium sp. & Mexico & Martinez and Charudattan, 1998 \\
\hline
\end{tabular}


2008). Host specificity assessments indicated that A. zonatum was a pathogenic reaction to sorghum-sudan grass (Sorghum vulgaris var Sudanese Hitche.) and cultivated tobacco (Nicotiana tabacum L.) in Sudan and water lettuce (Pistia stratiotes L.) in Mexico among the 31 plant species tested (Abdelrahim and Tawfig, 1984; Martinez and Gutierrez, 2001). Charudattan (2001a) reported A. zonatum as one of the potential fungal pathogens that could be used as a bioherbicide agent in areas where the strains are pathogenic to the water hyacinth but not to plants having economic and ecological importance (e.g., Mexico).

Alternaria alternata: This fungus has been described as a pathogen of water hyacinth in Australia (Galbraith and Hayward, 1984), Egypt (Shabana et al., 1995a, b; El-Morsy 2004; El-Morsy et al., 2006), Bangladesh (Bardur-ud-Din, 1978), and India (Aneja and Singh, 1989; Mohan et al., 2002,2003). This pathogen has been evaluated as a nonefficient biocontrol agent (Bardur-ud-Din, 1978; Aneja and Singh, 1989). Recently, the pathogen was evaluated intensively as a biocontrol agent in India and Egypt (Mohan et al., 2002, 2003; El-Morsy et al., 2006). Test results indicated that the fungus was highly virulent on water hyacinth, leading to plant death. Its symptoms (i.e., spots and lesion) were mainly expressed on the leaves but not on the stolons. The host range assessment result indicated that only P. stratiotes (both in India and Egypt) and foxtail sedge (Cyperus alopecuroides Rottb.) (Egypt) were susceptible to the fungus (Mohan et al., 2002; El-Morsy et al., 2006). These studies indicate that the fungus has potential as a bioagent of water hyacinth, and its toxins may have use as a herbicide.

Alternaria eichhorniae: This fungal pathogen has been reported to occur on water hyacinth in Egypt, Sudan, Kenya, Zimbabwe, Ghana, Uganda, Niger, Tanzania, South Africa, India, Indonesia, and Thailand (Evans and Reeder, 2001; Shabana, 2002). It has been shown to be fairly host specific to water hyacinth (Nag Raj and Ponnappa, 1970; Shabana et al., 1995a) and to be capable of severely damaging and suppressing this weed (Shabana et al. 1995a, b). A good understanding of the biology and pathology of the fungus has been gained (Shabana et al., 1995a, b, 1997, 2000, 2001a, b). As a result, this fungus isolate Number 5 (Ae5) is being developed as a mycoherbicide for controlling water hyacinth in Egypt (Shabana, 2005).

Cercospora piaropi (=Cercospora rodmanii): Cercospora piaropi and C. rodmanii Conway were both recognized as pathogens of water hyacinth until Tessmann et al. (2001) merged the two species into an emended C. piaropi. This fungal pathogen is widely distributed worldwide (Evans and Reeder, 2001). Host specificity studies 
indicated the fungus is only pathogenic to water hyacinth (Martinez and Gutierrez, 2001). However, the fungus isolates are believed to exhibit pathogenic variability depending on the growth and pigmentation in the culture. Hence, diffusible pigments in culture and cercosporin production could be used as adjuncts to screen aggressiveness of the most effective isolates of $C$. piaropi for biological control (Tessmann et al., 2008).

The present review clearly indicated A. zonatum, A. alternata, A. eichhorniae, and $C$. piaropi have been well evaluated as potential bioagents for the management of water hyacinth. Because most of these pathogens have a wide geographical distribution and produce virulent toxin or toxins, there is a good possibility they could be used as inundative bioagents. Once a native, virulent, and safe pathogen has been identified and evaluated, its use as a mycoherbicide avoids the quarantine issues associated with exotic pathogens. Charudattan (2001a, b), Bateman (2001), and Ding et al. (2008) have elaborated on the potential advantages of using of native pathogens. Thus, exploration for native fungal pathogens should continue.

\subsubsection{Recent advances and opportunities}

Recent advances using pathogens as bioagents for water hyacinth management include the development of mycoherbicides. Modern research on mycoherbicides has focused on two fungal species: $C$. piaropi and $A$. eichhorniae. The fungal pathogen $C$. piaropi was developed into a bioherbicide by Abbott Laboratories for water hyacinth management. The formulation was a wettable powder that was applied with a humectant to preserve moisture and nutrients to sustain and stimulate propagule germination (Pennington and Theriot, 1983). Although laboratory results appeared promising (Pennington and Theriot, 1983), high infectivity was not achieved in the field, and further development of the bioherbicide was curtailed (Sanders and Theriot, 1986). Two novel mycoherbicides developed from Sclerotinia sclerotiorum (Lib.) de Bary and Thanatephorus cucumeris (=R. solani) (A.B. Frank) Donk AG 2-2 for biological control of aquatic weeds, such as water hyacinth and water lettuce, were patented to Meindert de Jong and Barend de Voogd (Wageningen University) in 2003. Sclerotinia sclerotiorum, known as a plurivorous plant pathogen, has never been observed on water hyacinth. Plants susceptible to this pathogen include many dicotyledons. It is geographically cosmopolitan and has a broad ecological distribution. The fungus is seldom observed on monocotyledons, and never observed on aquatic species such as water hyacinth and water lettuce. The efficacy of the mycoherbicide developed from $S$. sclerotiorum, evaluated at three rates, is presented in Figure 3.3. 


\section{Chapter 3}

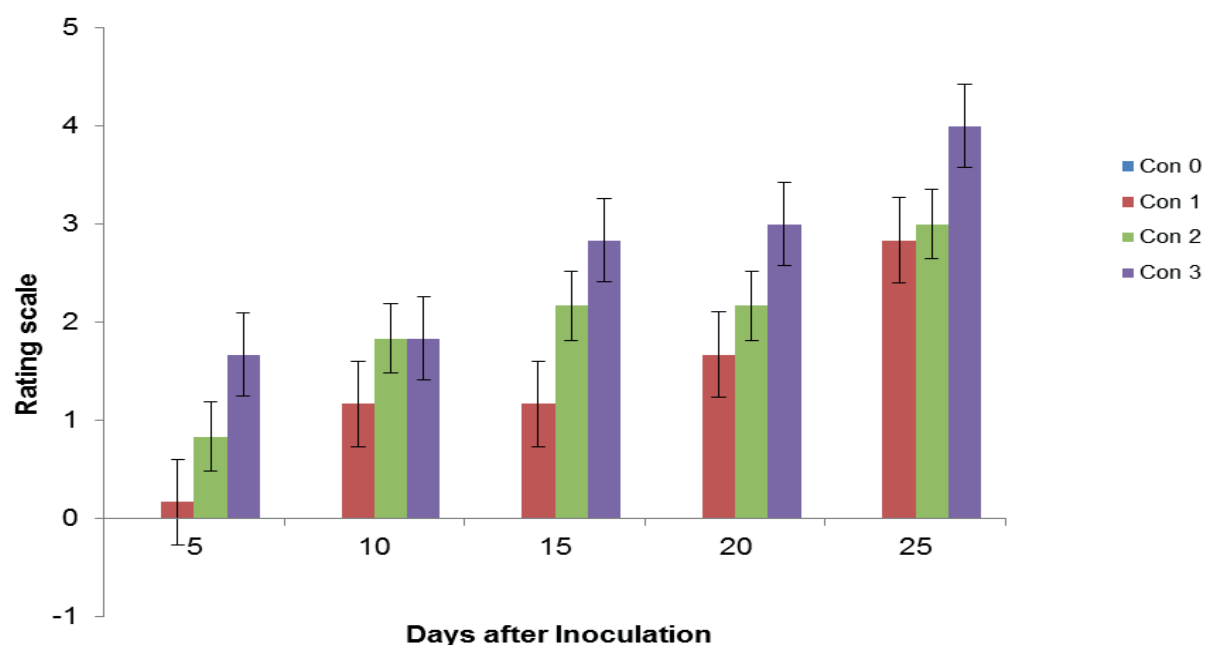

Figure 3.3. Disease score for six water hyacinth plants treated with Sclerotinia sclerotiorum mycoherbicide at three concentrations. Where rating $0=$ None-no symptom $(0 \%$ shoot area exhibiting disease symptom), 1 = Very low-small superficial lesion (1-10\% shoot area), 2 = Low-small discreet lesion (11-25\% shoot area), 3 = Medium-large systemic lesion (26$75 \%$ shoot area), $4=$ High-significant plant necrosis $(78-99 \%$ shoot area $)$ and $5=$ Plant dead (100\% shoot area).

Researchers in Egypt have been studying the use of $A$. eichhorniae for biological control of water hyacinth. A major obstacle with water hyacinth was its requirement for at least $10 \mathrm{~h}$ of dew to allow the applied inoculum to germinate and infect and, to some extent, colonize the weed (Shabana et al., 1995a). Longer exposure to dew (e.g., 26 or $28 \mathrm{~h}$ ) might ensure disease development, but such uninterrupted, long exposure to dew periods is not likely to occur under field conditions. Shabana (2005) demonstrated the use of oil emulsions for improving the efficacy of A. eichhorniae Ae5. It could be formulated in a cottonseed-oil emulsion to eliminate its dew-period requirement and still allow it to cause high disease severity and weed kill under field conditions.

Interest in the use of fungi has continued; however, recent efforts have paired fungal pathogens with insects and/or insects and mycoherbicides in integrated biological approaches. Although complete control of water hyacinth was not achieved, Moran (2005) demonstrated that integrating weevils with $C$. piaropi in field plots increased necrosis and decreased shoot densities and leaves per plant. Water hyacinth weevils can vector $C$. piaropi under controlled conditions, but that association does not specifically increase the severity of the fungal symptoms or lead to enhanced negative effects on plants over one month. The feeding activities of weevils facilitate fungal 
colonization of water hyacinth tissues. Improvements in formulation technology and in the use of additional pathogens may improve the utility of plant pathogens in water hyacinth biocontrol. In a small reservoir in Mexico, Martinez and Gomez (2007) released approximately 9,800 weevils of Neochetina spp., followed by applications of the fungal plant pathogens $A$. zonatum and $C$. piaropi. Within three month, the reservoir was completely free of water hyacinth. Moran and Graham (2005) also reported a positive association between leaf scarring because of the mottled water hyacinth leaves and necrosis. This all suggests the feasibility and commercial potential of complementing weevils with pathogens for the management of water hyacinth.

\subsection{Research gaps and opportunities for use of biological control in Ethiopia}

In Ethiopia, use of classical biological control agents for the management of weeds began in the 1970s with the introduction of a weevil, Smicronyx albovariegatus (Coleoptera: Curculionidae) and a moth Eulocastra argentisparsa (Lepidoptera: Noctuidae) from India for the management of witchweed Striga Lour spp. However, none of them has established (Fasil, 2004). Weed biological control in Ethiopia is still in the experimental stages. Few studies have been undertaken to survey, identify, and evaluate native natural enemies associated with ragweed parthenium (Parthenium hysterophorus L.) (Taye et al., 2004a, b) and Striga spp. (Fasil, 2004; Rebka, 2006).

Although water hyacinth has been problematic for the past 60 year, its management using plant pathogens and insect bioagents has seldom been attempted. A survey carried out in the Gambella region of Ethiopia in the 1970s reported the fungus $C$. rodmanii, as affecting water hyacinth $5-15 \%$ (Stroud, 1994). This noxious, aquatic weed has created perennial problems in irrigation structures, hydro-electric dams, lakes, reservoirs, and drainage systems located in the Rift Valley of Ethiopia. Although attempts have been made to manage this weed by mechanical methods, the weed remains a threat for different stakeholders (Electric Power Authority, sugar estates, farmers, fishers, etc.). The use of bioagents for the management of invasive weeds at a national level has recently received increased attention, and researchers have engaged in surveys, introduction, and evaluation (pathogenicity and host specificity assessment) of native as well as classical bioagents. A survey of indigenous fungi found in association with water hyacinth was conducted in 2009 and 2010. During the survey, 25 fungal isolates were collected. Identification and molecular characterization of the isolates is in progress at Wageningen University, Wageningen, the Netherlands. However, their pathogenicity, host specificity, and application methods will require additional research. 


\section{Chapter 3}

The prevalence of $C$. piaropi and the 25 unidentified fungal pathogens indicates there are potential native pathogens that can be used for the management of water hyacinth. Because shortcomings with the use of pathogens as bioagents have been resolved and development of mycoherbicides is in progress, the use of fungal pathogens for the management of water hyacinth is increasing. In Ethiopia, it is possible to implement the use of fungal pathogens as an inundative bioagent. Additionally, the prospect of the vectoring potential of the weevils is being explored. Once studies on the potential and host specificity of the existing native fungal pathogens are completed, it may be possible to use the weevils in combination with native fungal pathogens.

\subsection{Conclusion}

Several host specific, virulent fungal pathogens, such as C. piaropi, A. eichhorniae, A. alternata, and others have widespread distribution. With the development of appropriate formulations, the possibility of using of pathogens as bioagents for the management of water hyacinth has improved, which could enable development of mycoherbicides from native, virulent fungal pathogens. The success achieved in the development of mycoherbicides enhances the overall effectiveness of the fungal pathogens under different scenarios. The use of native pathogens avoids quarantine issues associated with exotic pathogens. Moran (2005), Moran and Graham (2005), and Martinez and Gomez (2007) determined there is a great opportunity to integrate potential fungal pathogens with insects for the management of water hyacinth. In Ethiopia, exploring the use of existing native fungal pathogens as inundative bioagents and increasing mycobiota exploration, efficacy evaluation, and host specificity assessment must be undertaken.

Neochetina eichhorniae and N. bruchi are considered as classical bioagents in Ethiopia because of their host specificity, past history of damage to water hyacinth, and control of the weed in similar environments in other countries. These agents can be introduced from Sudan, Uganda, Kenya, Tanzania, or any other African or Asian countries. Based on the many success stories in Africa and elsewhere in the world with the use of bioagents for the management of water hyacinth, it appears that similar results are possible in Ethiopia.

\section{Acknowledgements}

The authors would like to thank EIAR-UNEP-GEF for funding as well as Ethiopian Sugar Corporation, for providing us with much needed logistical support. 
CHAPTER 4

\section{Occurrence and diversity of fungal pathogens associated with water hyacinth and their potential as biocontrol agents in the Rift Valley of Ethiopia}

Y. Firehun, P.C. Struik, E.A. Lantinga and T. Taye (2017)

International Journal of Pest Management

(published online 11 Jan 2017) 


\begin{abstract}
Water hyacinth poses serious socio-economic and environmental problems in Ethiopia. To integrate fungal pathogens into water hyacinth management, a survey was conducted in the Rift Valley of Ethiopia. Based on morphological characterization and DNA sequencing, 25 fungal species were identified that belong to nine genera. Alternaria tenuissima, A. alternata, Aspergillus niger, Phoma sp., Curvularia trifolii, Mucor fragilis, $M$. racemosus, A. fumigatus, Fusarium oxysporum and $F$. equiseti were the most common fungi detected. However, their occurrence was influenced by water wave action, temperature, season and altitude. Among the fungal pathogens, $A$. alternata, A. tenuissima, F. oxysporum, F. equiseti and Neofisicoccum parvum were highly pathogenic to water hyacinth. Alternaria alternata and A. tenuissima did not cause disease symptoms on ecologically important plant species (e.g. noug, teff, and coffee). Application of the fungal pathogens on water hyacinth plants also showed 11$67,22-72,15-55$ and $12-50 \%$ reduction in fresh weight, dry weight, plant height and root length of water hyacinth, respectively. This study suggests that fungal species have the potential to control water hyacinth biologically and provides baseline data for biological control efforts in the future.
\end{abstract}

Keywords: Biological control, Eichhornia crassipes, fungal pathogens, multivariate analysis, native bioagents, pathogenicity, risk assessment, water hyacinth 


\subsection{Introduction}

Water hyacinth (Eichornia crassipes [Mart.] Solms) is one of most noxious aquatic weeds in the world. The high growth rate of the plant and its ability to infest a wide range of freshwater habitats causes detrimental impacts on fisheries and related commercial activities, access to clean water, hydropower generation, irrigation, navigation along water courses and tourism. The impacts are most pronounced in developing countries, where human activities and livelihoods are closely linked with water systems (Bateman, 2001). In Ethiopia, water hyacinth (Pontederiaceae) was reported from Koka Lake and the Awash River about 60 years ago (Stroud, 1994; Firehun et al., 2013). Since then, it has manifested itself on a large scale in many water bodies, including rivers, lakes, reservoirs, irrigation supplies and drainage systems (Stroud, 1994; Rezene, 2005; Taye et al., 2009). Various methods to control water hyacinth include manual and mechanical clearing and in some places chemical control. However, the use of herbicides to control water hyacinth is only effective in the short term anywhere in the world (Borokoni and Babalola, 2012; Dagno et al., 2011). Biological control of water hyacinth, which involves the use of natural enemies (i.e. insects and fungal pathogens) has been reported to be the most economical and sustainable method of control (Firehun et al., 2013). Fungal pathogens have gained acceptance as a practical, safe, environmentally friendly weed management method in agro-ecosystems worldwide (Charudattan, 2001b) although their use has not been adopted in Ethiopia. Recommendations have been made to integrate fungal pathogens with insects to improve biological control of water hyacinth due to the insect feeding damage facilitating pathogenic infections of water hyacinth leaves (Martinez and Gutierrez, 2001).

Several fungal pathogens have been reported to attack water hyacinth worldwide (Shabana et al., 1995a, b, 1997, 2000; Charudattan, 2001b). Various strains in the genera Acremonium, Alternaria, Cercospora, and Myrothecium have been studied intensively as biocontrol agents and shown to be effective under experimental conditions (Shabana et al., 1995a, b, 1997, 2000; Charudattan, 2001b; Martinez and Gutierrez, 2001; Mohan et al., 2003; Praveena and Naseema, 2004). One fungal species, Cercospora piaropi, originally described as C. rodmanii (Conway, 1976a) and patented by the University of Florida (Conway et al., 1978) was developed into a bioherbicide by Abbott Laboratories (Chicago, IL) for water hyacinth management. In Africa, several pathogenic fungi that attack water hyacinth offer great potential to be developed in to mycoherbicides (Bateman, 2001). For example, in Egypt, Alternaria eichhorniae was developed into a mycoherbicide for the control of water hyacinth (Shabana, 2005). 


\section{Chapter 4}

In an effort to integrate fungal pathogens into water hyacinth management, this chapter investigates the diversity of fungal pathogens associated with water hyacinth in Ethiopia, their impact on the growth of water hyacinth plants and their safety on important plant species.

\subsection{Materials and methods}

\subsubsection{Survey and isolation of fungi associated with water hyacinth}

Diseased water hyacinth leaves (showing browning, wilting, yellowing, spots, blights, or combinations thereof) were collected from water bodies (in and along Aba-Samuel Dam, Lake Bishoftu, Lake Koka, Lake Beseka, Koka Dam, Awash Dam, Lake Ellen, Lake Elltoke, Wonji-Shoa sugar estate, and Metahara sugar estate) in the Ethiopian Rift Valley from 2009 to 2011. Diseased leaf specimens were taken to the laboratory and stored at $4{ }^{\circ} \mathrm{C}$ in a refrigerator. Small sections of the diseased tissue (2-4 $\left.\mathrm{mm}^{2}\right)$ were cut from the margins of necrotic or chlorotic lesions and surface-disinfected for one minute in $10 \%$ sodium hypochlorite. The tissue pieces were rinsed three times with sterile water and four tissue pieces were plated on potato dextrose agar (PDA; Merck KGaA, Germany) in each Petri dish and incubated at $25{ }^{\circ} \mathrm{C}$. The Petri dishes were checked for fungal growth after 2-4 days and thereafter on a daily basis for 20-30 days. Pure colonies of the isolates were grown by single-spore or hyphal-tip techniques (Martinez and Charudattan, 1998). The isolates were stored on agar slants at $6{ }^{\circ} \mathrm{C}$ in a refrigerator. The frequency of occurrence of the isolates were rated as very frequent $(>20 \%)$, frequent $(10-20 \%)$ and infrequent $(<10 \%)$ according to El-Morsy (2004).

\subsubsection{Characterization and identification of water hyacinth fungi}

Fungal isolates were obtained from agar slants using a cork borer ( $5 \mathrm{~mm}$ diameter) and transferred onto freshly prepared PDA media amended with streptomycin sulphate in $80 \mathrm{~mm}$ Petri dishes. The plates containing each isolate were arranged in a completely randomized design, with each isolate replicated four times. Colony diameter of each isolate was measured three days after incubation at $25^{\circ} \mathrm{C}$ and thereafter on a daily basis for seven consecutive days. The colony appearance and colour on PDA in the Petri dishes were recorded for three days after incubation using the Munsell soil colour chart (1994). The fungal isolates were characterized morphologically under a microscope based on their mycelium, fruiting structures and spores and identified according to Ainsworth et al. (1973) and Barnett and Hunter (1972).

To confirm the identity of fungal isolates, molecular characterization was conducted at the Farming Systems Ecology Group Laboratory, Wageningen University, 
Netherlands. DNA was extracted by using FastDNA®Spin Kit (Q-Biogene, Germany). Electrophoresis and nano-drop measurements were conducted to determine purity, concentration and integrity of isolated DNA. Polymerase chain reaction (PCR) was performed in a total volume of $25 \mu$ l containing Nuclease free water, PCR MM Promega, ITS1 primer, ITS4 Primer and target DNA. The mixture was incubated in a Thermocycler (Spectrum 48 real Time, Germany). The intertranscribed spacer (ITS) regions including ITS1, 5.8S, and ITS2 regions of fungal ribosomal DNA were amplified with primers ITS1 and ITS4 (White et al., 1990) with an initial denaturing step at $94{ }^{\circ} \mathrm{C}$ for five minutes followed by 30 cycles of denaturation at $94{ }^{\circ} \mathrm{C}$ for two minutes, annealing at $57{ }^{\circ} \mathrm{C}$ for one minute and elongation at $72{ }^{\circ} \mathrm{C}$ for two minutes. The PCR amplicons were purified by using MiniElute PCR purification kit (Qiagen, Germany) using a microcentrifuge. The purified PCR products $(10 \mu \mathrm{l})$ were directly sequenced by using an automated sequencer. The nucleotide sequences were aligned by using a nucleotide-blast programme (MegaBlast) in the Greenomics Laboratory of Wageningen University and the results showed a close phylogenetic match with other known isolates of the same taxon.

\subsubsection{Pathogenicity tests}

Healthy water hyacinth plants (collected from Wonji-Shoa irrigation and drainage canals) were grown in plastic buckets $(50 \mathrm{~cm}$ diameter and $40 \mathrm{~cm}$ height $)$ filled with water and were acclimatized for 15 days inside a lath house. Mycelia or spores from 10 days old laboratory cultures grown on PDA in Petri dishes were obtained aseptically and blended with $10 \mathrm{ml}$ of sterile distilled water. The blended mycelium and spore suspension were diluted to give $1 \times 10^{6}$ propagule $\mathrm{ml}^{-1}$ (El-Morsy, 2004) and $20 \mathrm{ml}$ of the suspension was applied on to water hyacinth leaves by using hand sprayers. Young leaves of water hyacinth plants were rubbed with carborundum (a universally used abrasive) and painted with Tween 80 to ensure penetration and subsequent infection by mycelia and spores. Water hyacinth leaves were also rubbed with carborundum and sprayed with sterile distilled water and used as controls. The inoculated and control plants were covered with clear plastic bags for two days to maintain a high relative humidity (Shabana et al., 1995a).

After inoculation, the buckets containing the water hyacinth plants were arranged in a completely randomized design and treatments were replicated three times. Plants were examined for disease symptom expression five days after inoculation for five weeks. Disease symptom expression on the water hyacinth leaves was rated on a severity scale of 0-5 (Waipara et al., 2006). The experiment was repeated three times.

The isolates with high disease severity (scores 3-5) were screened for their effect on

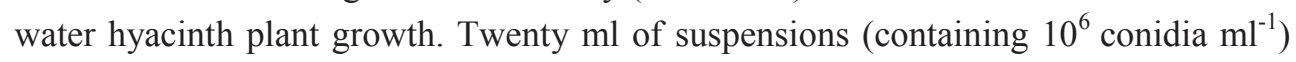




\section{Chapter 4}

were applied to water hyacinth leaves. To estimate disease incidence (DI), the number of infected leaves per the total number of leaves was counted after one and four weeks after inoculation, while disease symptom on each leaf was rated on a scale of 0-9 (Freeman and Charudattan, 1984). Values for individual leaves were summed and averaged to derive disease severity (DS) to determine DS for a whole plant. Fresh and dry weights of plants were recorded four weeks after inoculation. The experiment was repeated three times. Data on the DI, DS and plant biomass was analyzed using SAS Version 9.1 (SAS, 2008). To achieve normality, percentage data were arcsine transformed before analysis.

\subsubsection{Safety of water hyacinth fungi to plants}

The highly pathogenic isolates (scores 3-5) were screened for their safety by exposing them to a selection of aquatic weeds and economically important crop species. The crops were selected based on their ecological importance and their production in the lowland areas of the Ethiopian Rift Valley. The crops included; cereals (wheat, barley, sorghum, teff and maize); vegetables (onion, garlic, pepper, cabbage, tomato, radish, carrot and cucumber); pulses (haricot bean, soy bean, lentil, chickpea, faba bean, field pea); oil crops (sesame, noug, safflower); fiber crop (cotton); spices (fenugreek, cumin seeds and mustard); sugar crop (sugarcane); and stimulants (coffee).

Five seeds of each crop species, five plantlets of each aquatic weed species (water pennywort, water lettuce, typha and water hyacinth) and five single bud sets of sugarcane cuttings were planted in pots filled with sterilized soil and each plant species were replicated six times. The plants were thinned at three leaf stage to one plant and acclimatized in a lath-house for five days. The plants were sprayed with 20 $\mathrm{ml}$ suspension having $1 \times 10^{6}$ conidia $\mathrm{ml}^{-1}$ concentration of the respective fungal isolates.

In each pot, the various plant species were also left untreated as controls. After seven days, all plants were examined for disease symptoms such as ovate leaf spot with a brownish center, necrotic foliar spot, browning and leaf blight. The isolates that showed symptoms were further re-isolated and tested to demonstrate Koch's postulate. The experiment was repeated three times.

\subsubsection{Fungal species dominance in relation to water and environmental factors}

Community analysis was used to relate fungal species dominance to water and environmental factors. Disease severity was estimated for each water hyacinth leaf in 4 $\mathrm{m}^{2}$ quadrats at monthly intervals from 2009 to 2011 . Water quality and environmental conditions including temperature, wave action, $\mathrm{pH}, \mathrm{N}, \mathrm{P}, \mathrm{EC}$, rainfall and altitude were analysed. Disease severity data were transformed using arcsine transformation. 
Disease severity, fungal species, water quality and environmental data were subjected to multivariate analysis of variance (MANOVA). Multivariate regression analysis was used to quantify associations of groups of response variables (species and DS) and independent variables (water quality and environmental variables). All analyses were done on the Statistical Analysis System using multivariate general linear model procedure (SAS Institute, 2008).

Finally, Canoco, a Fortran program version 4.5 (Ter Braak, 2003) was used to determine the association of fungal species with water quality and environmental conditions.

\subsection{Results and discussion}

\subsubsection{Morphological and molecular characteristics and fungal species identity}

In total, 25 isolates sporulated within nine days of incubation and colonies formed different colours on PDA. Some isolates produced red pigment with reddish grey and dark reddish grey mycelia (Figure 4.1; Table 4.1). Colony growth varied with different isolates ranging from $0.5-2.5 \mathrm{~cm}^{-1} \mathrm{day}^{-1}$ and there were significant differences $(\mathrm{P}<0.05)$ in radial colony growth among the isolates (Table 4.1). The isolates were categorized as fast growing $\left(\geq 1.5 \mathrm{~cm} \mathrm{day}^{-1}\right.$, for isolate 1,9 and 21$)$, intermediate $(1.0-1.49 \mathrm{~cm}$ day $^{-1}$ for isolate $2,13,15,16$ and 23), and slow-growing $\left(<1.0 \mathrm{~cm} \mathrm{day}^{-1}\right.$ for isolate 2 , $3,4,5,6,7,8,10,11,12,14,16,17,18,19,20,22,24$ and 25). All fungal isolates, except isolate 11 , showed clear septation of mycelia after seven days of incubation on PDA, whereas isolates 4, 5 and 6 showed both horizontal and vertical macroconidial septation. The growth habit of isolates 4,5 and 6 were stretched, cottony or raised. The observed differences among the isolates in morphological characteristics in this study suggest that these isolate are a diverse assemblage of species.

The DNA banding of each isolates ranged between 500-700 bp (Figure 4.2). However, nano-drop measurements of the diluted DNA of isolates 5 and 12 revealed no abnormalities, i.e. a ratio of A260/A230 > 1.8. MegaBlast result of the respective fungal isolates indicated that both the forward and reverse primers identified the fungal isolates at the species or genus level with $<3 \%$ gap and most of the isolates were identified at about a $99 \%$ precision level. Differentiation of some isolates based on phenotypic differences, besides being unclear in some solutions, was supported by the DNA sequencing data.

Both morphological and molecular analyses showed that the fungal isolates belonged to nine genera (Table 4.2). Of these fungi, $A$. tenuissima $(23.5 \%)$ and $A$. alternata (26.5\%) were the most prevalent. Among the fungal pathogens, A. alternata, A. tenuissima, Phoma sp., Alternaria sp., F. oxysporum, and $F$. equiseti were the most 




Figure 4.1. The fungal isolates \# 1-25 colony appearance and colour in the Rift Valley water bodies of Ethiopia grown in PDA.

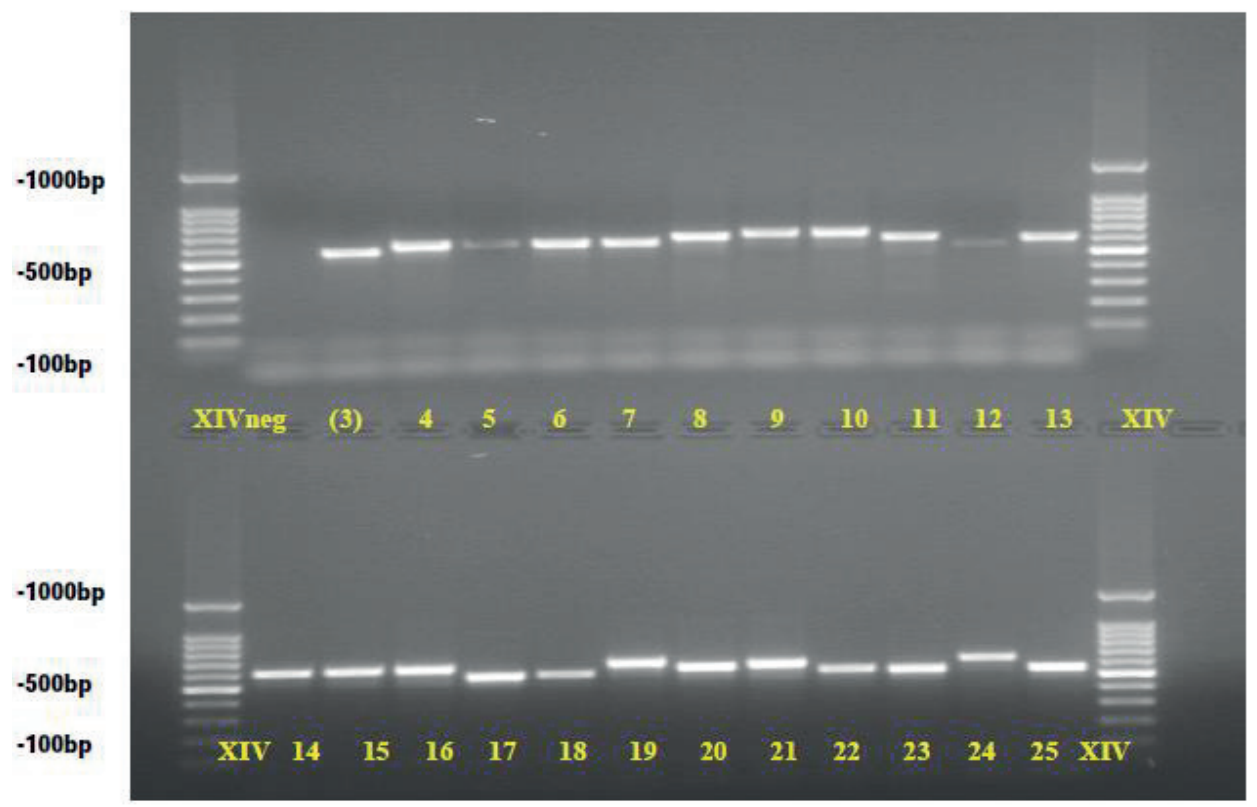

Figure 4.2. Validation of PCR using fungal primers ITS1-ITS4 for isolates \# 4-25. As a positive control DNA from isolate \# 3 was used. Amplicon size is between 500-700 bp. 
common species reported as pathogens of water hyacinth. Alternaria alternata has been described as a pathogen of water hyacinth in Australia (Galbraith, 1987), Egypt (Shabana et al., 1995a, b; El-Morsy, 2004; El-Morsy et al., 2006), Bangladesh (Bardur-ud-Din, 1978) and India (Aneja and Singh, 1989; Mohan et al., 2002, 2003). Research conducted in India and Egypt also indicated that this fungus has potential as a biocontrol agent of water hyacinth and its toxins may also be used as a herbicide (Mohan et al., 2002; El-Morsy et al., 2006). Despite the occurrence of several fungal species on water hyacinth, in Ethiopia, C. trifolii, M. fragilis, M. racemosus, $A$. fumigatus, Botryosphaeria sp., and $N$. parvum have not been previously isolated from water hyacinth.

Table 4.1. Colony description of fungal pathogens isolated from water.

\begin{tabular}{|c|c|c|c|c|}
\hline \multirow[b]{2}{*}{ Isolate } & \multicolumn{4}{|c|}{ Colony } \\
\hline & $\begin{array}{l}\text { Mean growth } \\
\text { rate day }^{-1}(\mathrm{~cm})\end{array}$ & $\begin{array}{r}\text { Front Plate } \\
\text { Colour }\end{array}$ & $\begin{array}{r}\text { Back Plate } \\
\text { Colour }\end{array}$ & $\begin{array}{c}\text { Surface } \\
\text { appearance }\end{array}$ \\
\hline 1 & 1.465 & Black & Yellow & Stretched \\
\hline 2 & 1.075 & Yellow green & Reddish gold & Cottony \\
\hline 3 & 0.696 & White with red & Light red & Cottony \\
\hline 4 & 0.662 & Grey & Black & Cottony \\
\hline 5 & 0.701 & Dark gray & Olive brown & Stretched \\
\hline 6 & 0.666 & Pale brown & Gray & Stretched \\
\hline 7 & 0.715 & Light gray & Very pale brown & Stretched \\
\hline 8 & 0.687 & Reddish gray & Black & Cottony \\
\hline 9 & 1.594 & Light gray & Pale yellow & Stretched \\
\hline 10 & 0.664 & Light gray & Pale yellow & Stretched \\
\hline 11 & 0.654 & Greenish gray & Yellow & Raised \\
\hline 12 & 0.768 & Light gray & Yellow & Stretched \\
\hline 13 & 1.012 & White & Gray & Cottony \\
\hline 14 & 0.471 & Dark gray & Gray & Stretched \\
\hline 15 & 1.302 & Greenish gray & Pale yellow & Stretched \\
\hline 16 & 1.004 & Greenish gray & Brownish yellow & Stretched \\
\hline 17 & 0.712 & $\begin{array}{r}\text { Reddish gray with red } \\
\text { circle }\end{array}$ & $\begin{array}{r}\text { Black with red } \\
\text { circle }\end{array}$ & Stretched \\
\hline 18 & 0.671 & White & Pale yellow & Cottony \\
\hline 19 & 0.708 & Light brownish gray & Gray & Stretched \\
\hline 20 & 0.700 & $\begin{array}{r}\text { Dark reddish gray with } \\
\text { red circle }\end{array}$ & $\begin{array}{r}\text { Black with red } \\
\text { circle }\end{array}$ & Stretched \\
\hline 21 & 2.456 & Grayish brown & Dark brown & Stretched \\
\hline 22 & 0.653 & Olive yellow gray circle & Very dark gray & Stretched \\
\hline 23 & 1.232 & White & Yellow & Cottony \\
\hline 24 & 0.776 & White & Pale yellow & Cottony \\
\hline 25 & 0.662 & White & Brownish yellow & Stretched \\
\hline
\end{tabular}


Table 4.2. List of fungal pathogens isolated from water hyacinth, their symptoms and frequencies of occurrence in the Rift Valley water bodies of Ethiopia (2009-2011).

\begin{tabular}{|c|c|c|c|}
\hline Isolates & Fungal Pathogens & $\begin{array}{c}\text { Symptoms and infected } \\
\text { plant part }\end{array}$ & $\begin{array}{l}\text { Frequency } \\
(\%)^{*}\end{array}$ \\
\hline 1 & Aspergillus niger VanTiegh & Leaf spot on leaf & 14.5 \\
\hline $2 \& 21$ & Aspergillus flavus Link ex Fr. & Leaf spot on leaf & 8.9 \\
\hline 3 & Phoma sp. & Blight on leaf and petiole & 10.4 \\
\hline 4 & Alternaria sp. & Leaf spot on leaf and petiole & 17.8 \\
\hline $5 \& 7$ & $\begin{array}{l}\text { Alternaria tenuissima (Nees ex Fr.) } \\
\text { Wiltshire }\end{array}$ & Leaf spot on leaf and petiole & 23.5 \\
\hline 6 & Alternaria alternata (Fr.) Keissler & Leaf spot on leaf and petiole & 26.2 \\
\hline 8 & Curvularia trifolii (Kauffman) Boedijn & Leaf spot on leaf & 11.2 \\
\hline $9,19 \& 24$ & Mucor fragilis Bull. & Blighting on leaves & 11.6 \\
\hline 10 & Mucor racemosus Fres. & Blighting on leaves & 14.2 \\
\hline 11 & Pencillium sp. & Zonate leaf spot on leaves & 6.7 \\
\hline 12 & Phoma macrostomata & Blight on leaves and petiole & 7.3 \\
\hline 13 & Neofusicoccum parvum & Leaf spot on leaf and petiole & 7.3 \\
\hline 14 & Aspergillus oryzae (Ahlburg) E. Cohn & Leaf spot on leaf & 11.0 \\
\hline 15 & Aspergillus fumigatus Fresenius & Leaf spot on leaf & 12.2 \\
\hline 16 & Fusarium equiseti (Corda) Saccardo & Leaf spot on leaf & 12.3 \\
\hline 17 & Phoma sp. & Blighting on leaves & 7.4 \\
\hline 18 & Fusarium oxysporum Schlechtendal & Leaf spot on leaf & 13.8 \\
\hline 20 & Botryosphaeria sp. & Zonate leaf spot on leaves & 6.5 \\
\hline 22 & Phoma sp. & Blighting on leaves & 7.4 \\
\hline 23 & Phoma sp. & Blighting on leaves & 7.4 \\
\hline 25 & Phoma sp. & Blight on leaves and petiole & 7.4 \\
\hline
\end{tabular}

* Frequency is the number of locations in which a species occurred expressed as a percentage of the total number of locations surveyed.

\subsubsection{Pathogenicity to water hyacinth}

Among the various fungal isolates, ten were pathogenic to water hyacinth, while six were found to be severely pathogenic (showing $>70 \%$ severity) to water hyacinth in the present study (Table 4.3). The disease symptoms occurred 8-14 days after inoculation. As the symptoms progressed, they coalesced and covered a larger surface area of the leaves within five weeks after inoculation (WAI), while other isolates showed restricted spread. The pathogenic fungal pathogens observed in the present study have also been reported from other countries (Barreto et al., 2000; Charudattan, 2001b; El-Morsy, 2004; Ray, 2006). Although the fungal species N. parvum was reported for the first time as pathogenic to water hyacinth, it also attacks Eucalyptus spp. and Tibouchina spp. (Pavlic et al., 2007; Heath et al., 2011). 


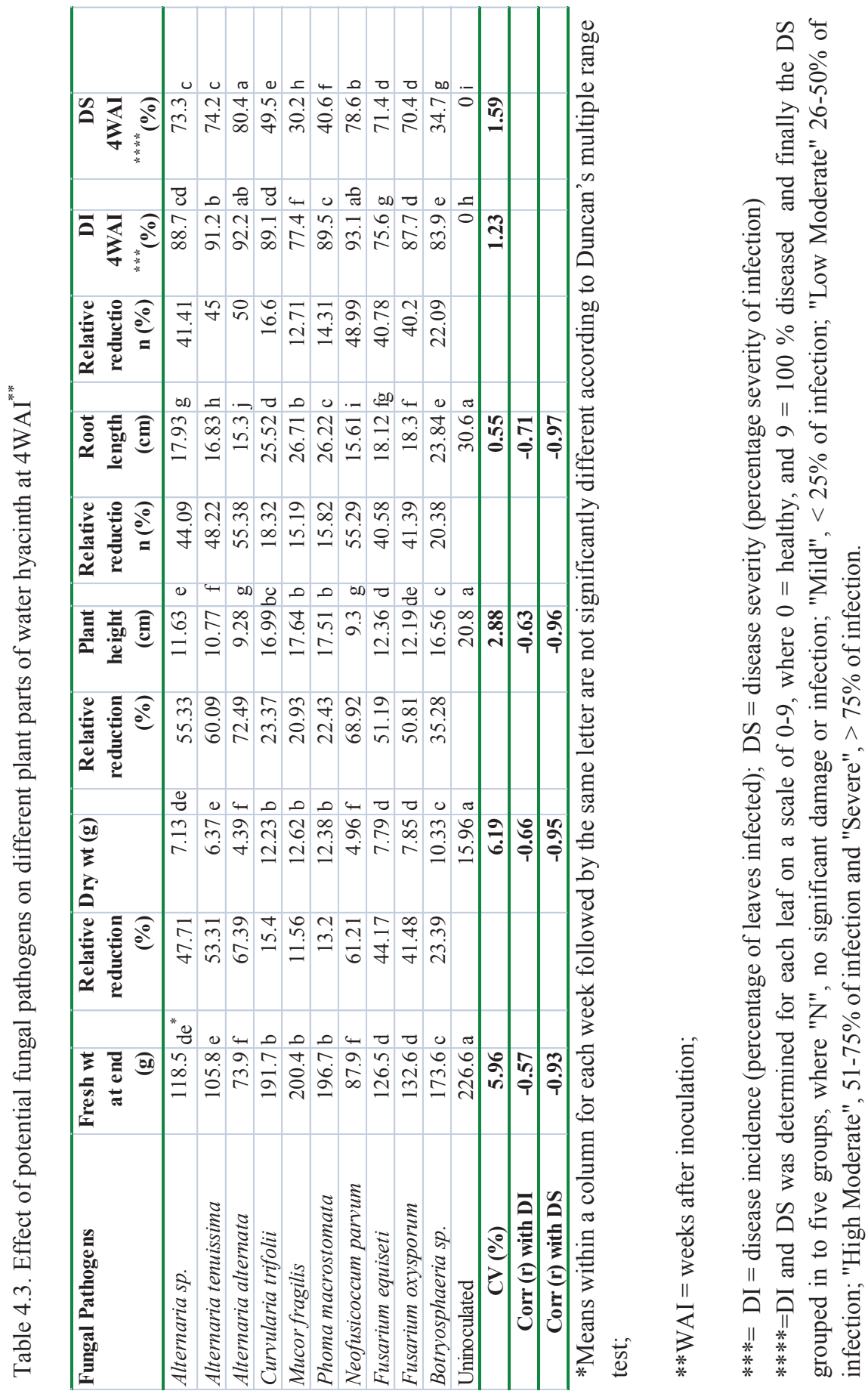




\subsubsection{Effect of fungal pathogens on water hyacinth plant growth}

The pathogenic fungi showed significant differences in the impact on the growth of water hyacinth plants (Table 4.3). Severe reduction in plant height (48-55\%), root length (45-50\%), fresh (53-67\%) and dry weight (60-72\%) was recorded due to infection by A. alternata, N. parvum and A. tenuissima, compared to small reductions in plant height (15-18\%), fresh (11-15\%) and dry weight (20-23\%) due to $M$. fragilis, P. macrostomata, and C. trifolii, respectively. Meanwhile fungi such as Alternaria sp., $F$. equiseti, and $F$. oxysporum showed low to moderate reduction (26-50\%). There were negative and significant associations $(\mathrm{r}>-0.93)$ between DS and dry weight, growth rate as well as other growth parameters (Table 4.3). These findings indicate that some fungal species may be useful in water hyacinth management since they affect the growth of water hyacinth plants. The reduction in plant height and biomass following exposure to fungal pathogens suggests that the number of reproductive and vegetative propagules of water hyacinth and the doubling time of the plant would be prolonged. In other studies, Shabana et al. (1995b) and Shabana (2005) also reported reductions in water hyacinth growth and reproduction due to infection by fungal pathogens, reinforcing the potential for pathogenic fungi to play an important role in weed management. Damage by pathogenic fungi to water hyacinth plants results in rotting of the lower petioles, waterlogging of the crown and gradual sinking of the plant (De Jong and De Voogd, 2003) leaving the water surface clear of the weed.

\subsubsection{Safety of water hyacinth fungi to plants}

Among the fungal species, $F$. oxysporum was pathogenic to a wide range of plant species, including cabbage, papyrus, mustard, chickpea, faba bean, pea, lentil, fenugreek, sesame and pepper (Table 4.4). Meanwhile, $F$ equiseti was pathogenic to tomato, cabbage, haricot bean, soy bean, mustard and pepper. N. parvum was pathogenic to carrot and tomato. The most susceptible crops were sesame, tomato, fenugreek, pepper, haricot bean and mustard while cotton, sweet potato, sugarcane, cumin, maize, wheat and radish were not infected by the fungal pathogens. Similarly, A. alternata, Alternaria sp., A. tenuissima, F. oxysporum and N. parvum showed severe leaf necrosis on water lettuce. Re-isolation of the fungi from all symptomatic plants confirmed the occurrence of the respective fungus as the causative agent of the disease symptoms. The lack of susceptibility of plants inoculated with A. alternata, A. tenuissima, and Alternaria sp. suggests that some plant species may be immune to these pathogens. In another study, Rhomela et al. (1999) reported that A. alternata did not infect lettuce, soybean, common bean, winged bean, mung bean, string bean, banana, and rice but caused some disease on cabbage, radish and okra. 
Table 4.4. Risk Assessment of fungal morphotypes proved to be pathogenic to water hyacinth.

\begin{tabular}{|c|c|c|c|c|c|c|c|}
\hline Family & Species and Common Name & ALLAL & ALNSP & ALLTE & FUSOX & FUSEQ & NEOPA \\
\hline \multirow[t]{2}{*}{ Apiaceae } & Daucus carota L. cv. unknown; Carrot $^{\text {a }}$ & - & - & _- & - & - & + \\
\hline & Hydrocotyle verticillata $L$. Water pennywort ${ }^{\mathrm{b}}$ & - & - & - & _- & - & _- \\
\hline Araceae & Pistia stratiotes L.; Water lettuce ${ }^{\mathrm{b}}$ & +++ & +++ & +++ & +++ & +++ & +++ \\
\hline Asteraceae & Guizotia abyssinica cv. Fogera; Noug ${ }^{\text {a c d }}$ & - & _ & _ & _ & + & _ \\
\hline \multirow[t]{2}{*}{ Brassicaceae } & Raphanus sativus L. cv. unknown; Radish ${ }^{\mathrm{c}}$ & _ & _ & _ & - & _ & _ \\
\hline & Brassica oleracea capitata L. cv. unknown; Cabbage ${ }^{\text {a c }}$ & _ & _ & _ & ++ & +++ & _ \\
\hline Chenopodiaceae & Ipomea batata (L.) Lam. cv unknown; Sweet potato ${ }^{\text {a }}{ }^{2}$ & - & _- & _- & _- & _ & _ \\
\hline Cyperaceae & Cyperus papyrus L. Papyrus ${ }^{\mathrm{b}}$ & 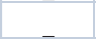 & - & - & ++ & - & 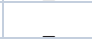 \\
\hline Compositae & Carthamus tinctorius L. cv. unknown; , safflower ${ }^{\text {a }}$ & _- & _- & - & _- & _- & - \\
\hline Cruciferae & Brassica carinata Cobs. cv. Holleta 1; Mustard ${ }^{\text {a } \mathrm{cd}}$ & _ & - & _ & ++ & ++ & _ \\
\hline Cucurbitaceae & Cucumis sativus L. cv. unknown; Cucumber ${ }^{\text {a }}{ }^{2}$ & _- & _- & _- & _- & _- & _- \\
\hline \multirow[t]{7}{*}{ Fabaceae } & Phaseolus vulgaris L. cv. Awash Melka; Haricot bean ${ }^{\text {ac }}$ & - & - & - & - & ++ & - \\
\hline & Glycin $\max$ (L) Merr. cv. Williams; Soy bean ${ }^{\text {a c }}$ & _- & _- & _- & _- & ++ & _- \\
\hline & Cicer arietinum L. cv. Chefe; Chickpea ${ }^{\text {a }}$ & _- & _- & _ & ++ & _ & _ \\
\hline & Vicia faba L. cv. Holleta 80 ; Faba bean ${ }^{\text {a c }}$ & - & - & - & ++ & _- & - \\
\hline & Pisum sativum L. cv. Holleta $90 ; \mathrm{Pea}^{\text {a c }}$ & _- & _- & _- & ++ & + & - \\
\hline & Lens culinaris Medik $c$ v. Chekol; Lentil ${ }^{\text {a c }}$ & - & _- & - & + & _- & - \\
\hline & Trigonella foenum-graecum cv. unknown; Fenugreek ${ }^{\text {a d }}$ & _- & _- & _- & +++ & _- & _ \\
\hline \multirow[t]{2}{*}{ Lileaceae } & Allium sativum L. cv. G-493; Garlic ${ }^{\text {a c }}$ & - & _ & _ & _ & _- & _ \\
\hline & Allium cepa L. cv Shallot; Onion ${ }^{\text {a c }}$ & _- & _- & _- & _- & +++ & _ \\
\hline Malvaceae & Gossypium hirsutum L. cv. Arba; Cotton ${ }^{\text {a c }}$ & _- & _- & _- & _- & - & _- \\
\hline Pedaliaceae & Sesamum indicum L. cv. Adi; Sesame ${ }^{\text {acd }}$ & _- & _- & _- & +++ & +++ & _- \\
\hline \multirow[t]{6}{*}{ Poaceae } & Hordeum vulgare L. cv. Desta; Barley ${ }^{\text {a }}$ & _- & _ & - & _- & _- & - \\
\hline & Sorghum bicolar (L.) Moench cv. IS9302, Sorghum ${ }^{\text {a }}$ & - & _- & _ & _- & _ & _ \\
\hline & Zea mays L. cv. Melkassa III; Maize ${ }^{\text {a c }}$ & - & - & - & _- & _- & - \\
\hline & Eragrostis tef (Zuccagni) Trotter cv. Kuncho, Teff ${ }^{\text {a d }}$ & 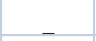 & 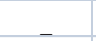 & _- & _- & _- & _ \\
\hline & Saccharum officinarum L, cv. B52298, Nco 334, N14; S & _ & _- & _- & _- & _- & _- \\
\hline & Triticum aestivum L. cv. Asasa, Wheat ${ }^{\text {ad }}$ & _- & _- & _- & _- & _- & _- \\
\hline Rubiaceae & Coffee arabica L. cv. Gesha, Coffee ${ }^{\text {ad }}$ & & & & + & - & - \\
\hline Pontederiaceae & Eichhornia crassipes (Mart.) Solms. Waterhyacinth & +++ & +++ & +++ & +++ & +++ & +++ \\
\hline \multirow[t]{3}{*}{ Solanaceae } & Lycopersicon esculentum Mill. cv. Melka-Shola; Tomato ${ }^{a}$ & 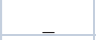 & _ & - & _- & +++ & +++ \\
\hline & Capsicum pepper cv. Mareko-Fana; Pepper ${ }^{\text {a }}$ & 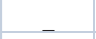 & - & - & +++ & +++ & - \\
\hline & Solanum tuberosum L. cv. Awash; Potato a c & - & - & - & - & - & _- \\
\hline Typhaceae & Typha orientalis Roscoe $^{\mathrm{b}}$ & 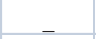 & 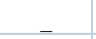 & - & - & . & + \\
\hline Umbelliferae & Cuminum cyminum cv. unknown; Cumin seed ${ }^{\mathrm{d}}$ & & & & & & \\
\hline
\end{tabular}

a plants of economic importance; ${ }^{b}$ plants ecologically related to water hyacinth; ${ }^{c}$ plants reported susceptible to test fungi; and ${ }^{\mathrm{d}}$ plants ecologically important. Bayer Code: ALLAL: Alternaria alternata, ALLTE: Alternaria tenuissima, ALLSP: Alternaria sp., FUSEQ: Fusarium equiseti, FUSOX: F. oxysporum and NEOPA: Neofusicoccum parvum.

Disease reaction from leaf inoculation; - no reaction; + slight; ++ moderate; +++ severe leaf necrosis.

Similarly, in this study, A. alternata did not infect any of the plant species except water hyacinth and water lettuce, which indicate their safety against plants. However, it has been described as a worldwide pathogen of water hyacinth (El-Morsy et al., 2006). 


\section{Chapter 4}

Both $F$. equiseti and $F$. oxysporum were able to produce moderate to severe leaf necrosis on 13 out of the 35 plant species tested. The host range of $F$. equiseti and $F$. oxysporum on economically important plant species have been adequately described (Abdelrahim and Tawfig, 1984; Jamil and Rajagopal, 1986; Taye et al., 2009). Conversely, in India, a risk assessment study revealed that $F$. equiseti was not pathogenic to any of the crop plants tested except amaranthus (Naseema et al., 2001). The susceptibility of plant species to $F$. equiseti in the present study may, therefore, be attributed to the occurrence of different strains of the pathogen and would preclude their use as biocontrol agents of water hyacinth.

\subsubsection{Fungal species dominance in relation to water and environmental factors}

Multivariate analysis of variance (MANOVA) indicated that the occurrence of fungal pathogens was significantly influenced by wave action, ambient temperature, season (survey month) and altitude (Table 4.5). Multivariate regression analysis indicated that fungal pathogens and their extent of occurrence have significant associations with water quality and environmental variables. Among the water quality and environmental factors, regression analysis indicated that altitude and survey month had a positive and significant influence on the fungal pathogens occurrence and level of severity. Similarly, a unit change in altitude and month resulted in an increase in extent of disease severity by 0.45 and $2.93 \%$, respectively.

A Canonical Correspondence Analysis (CCA) was used to ordinate the fungal species dominance percentage data in relation to the environmental and water variables (Ter Braak, 2003). The first two ordination axes explained $71.4 \%$ of the total variance in the weighted averages for dominance of the fungal pathogens with respect

Table 4.5. Multivariate analysis of variance using 'Wilks' test.

\begin{tabular}{lrrrc}
\hline Parameters $^{\mathrm{a}}$ & DF & F value & Pr $(>\mathbf{F})$ & Significance $^{\mathbf{b}}$ \\
\hline Altitude & 1 & 9.61 & 0.001 & \\
$\mathrm{pH}$ & 1 & 3.07 & 0.079 & \\
Month & 1 & 69.54 & $<2.2 \mathrm{e}^{-16}$ & ${ }^{* * *}$ \\
Rainfall & 1 & 30.64 & $3.796 \mathrm{e}^{-08}$ & ${ }^{* * *}$ \\
Temperature & 1 & 78.35 & $<2.2 \mathrm{e}^{-16}$ & ${ }^{* * *}$ \\
EC & 1 & 0.03 & 0.871 & \\
Wave & 1 & 5.82 & 0.015 & $*$ \\
Nitrogen & 35 & 2.50 & $4.054 \mathrm{e}^{-6}$ & ${ }^{* * *}$ \\
Phosphorus & 1 & 0.11 & 0.736 & \\
\hline
\end{tabular}

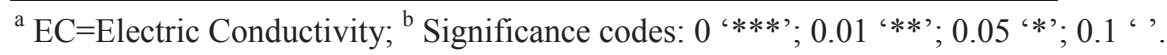


to the environmental variables (Annex Table 1, page 75). Several of the most frequent fungal pathogens such as A. alternata, A. tenuissima, Alternaria sp., F. oxysporum, $N$. parvum and Botryosphaeria sp. were located near the origin of the ordination diagram (Figure 4.3) indicating their ability to thrive under very diverse agro-ecosystems. In agreement with this finding, Firehun et al. (2013) reported that A. alternata, A. tenuissima, Alternaria sp., and $F$. oxysporum, have a wide geographical distribution and produce virulent toxins. Their wide distribution in the Rift Valley of Ethiopia would also ensure the potential to use the fungal pathogens as a mycoherbicide and avoid the quarantine issues associated with exotic pathogens.

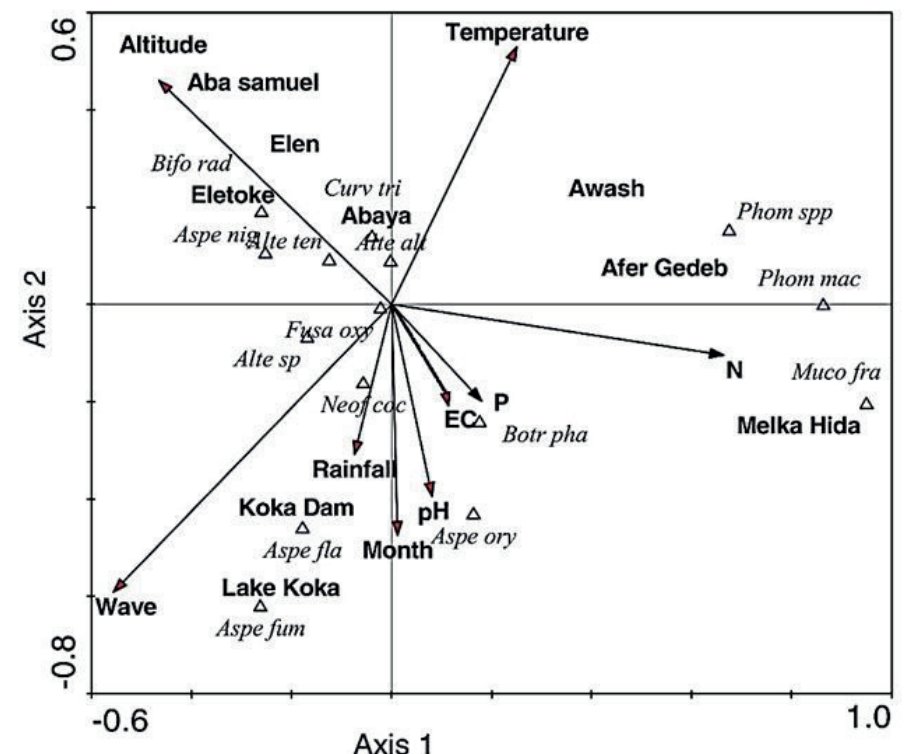

Figure 4.3. CCA ordination diagram of water hyacinth fungi in the Rift Valley water bodies of Ethiopia (Key to environmental and water variables is given in Annex Table 1). Texts in italics represent fungal species ${ }^{\Delta}$ while texts in uppercase and bold represent environmental and water variables ${ }^{\Delta \Delta}$. The variables with interval scale are represented by arrow and the nominal variables by centroids.

$\triangle$ Aspe nig = Aspergillus niger, Aspe fla $=$ Aspergillus flavus, Phom sp $=$ Phoma sp., Alte $s p$ $=$ Alternaria sp., Alte ten $=$ Alternaria tenuissima, Alte alt $=$ Alternaria alternata, Curv tri = Curvularia trifolii, Muco fra $=$ Mucor fragilis, Muco rac $=$ Mucor racemosus, Pen $s p=$ Pencillium sp., Phom mac = Phoma macrostomata, Neof par = Neofusicoccum parvum, Aspe ory = Aspergillus oryzae, Aspe fum = Aspergillus fumigatus, Fusa equ $=$ Fusarium equiseti , Fusa oxy = Fusarium oxysporum, Botr $s p=$ Botryosphaeria $s p$.

${ }^{\Delta \Delta}$ Water variables: wave (disturbance of water), $\mathrm{pH}, \mathrm{EC}, \mathrm{N} \& \mathrm{P}$ contents. 
In the CCA biplot (Ter Braak and Prentice, 1988) the length of arrows indicates the importance of the factors (longer arrows $=$ more important). Accordingly, among the variables considered, wave action, temperature and altitude were more important, followed by $\mathrm{N}$ content, survey month and $\mathrm{pH}$ than $\mathrm{EC}$, which had a short arrow. These results are in agreement with previous findings where the patterns of fungal abundance were influenced by most of the above-mentioned factors either positively or negatively (Mohan et al., 2003; El-Morsy, 2004; El-Morsy et al., 2006; Dagno et al., 2011).

\subsection{Conclusion}

Based on the analysis of data on pathogencity, host-range, and association with environmental and water factors, A. alternata, A. tenuissima, and Alternaria spp. hold promise as possible biocontrol agents of water hyacinth. Infection by these fungal pathogens resulted in reductions in fresh weight, dry weight, plant height and root length. They did not cause disease symptoms when inoculated onto plants of economical and ecological importance in Ethiopia, demonstrating they do not pose a risk to these tested plants.

\section{Acknowledgements}

We acknowledge EIAR-UNEP-GEF and Ethiopian Sugar Corporation for funding this research work. We are grateful to Mr. Oscar de Vos, Mr. Yohannes Zekarias and Mrs. Dine Volker for technical support. We also acknowledge Ambo Plant Protection Research Center for allowing us to use their Laboratory facilities. 
Annex Table 1. Environmental and water variables used in a canonical correspondence analysis (CCA) and their interset correlations with the first two ordination axes from a CCA of fungal dominance percentage in the Rift Valley water bodies of Ethiopia.

\begin{tabular}{lcc}
\hline \multirow{2}{*}{ Variables (scale)* } & \multicolumn{2}{c}{ Interset correlations } \\
\cline { 2 - 3 } Altitude (Nominal) & -0.4576 & Axis 2 \\
pH (Nominal) & 0.0799 & 0.4391 \\
Survey Month (Interval) & 0.0123 & -0.3756 \\
Rainfall (Nominal) & -0.0729 & -0.4521 \\
Temperature (Nominal) & 0.2464 & 0.5633 \\
EC (Nominal) & 0.1340 & -0.1965 \\
Water Wave (Nominal) & -0.5463 & -0.5042 \\
N (Nominal) & 0.6528 & -0.0996 \\
P (Nominal) & 0.1768 & -0.1890 \\
Water bodies (Interval) & & \\
$\quad$ Aba-Samuel Dam & -0.2725 & 0.4055 \\
$\quad$ Lake Ellen & -0.1909 & 0.2850 \\
$\quad$ Lake Elltoke & -0.2275 & 0.1854 \\
$\quad$ Lake Koka & -0.2179 & -0.4853 \\
$\quad$ Koka Dam & -0.1993 & -0.4499 \\
$\quad$ Melka Hida & 0.4313 & -0.1706 \\
$\quad$ Afer Gideb & 0.4068 & 0.0424 \\
$\quad$ Awash & 0.3431 & 0.1986 \\
$\quad$ Lake Abaya & -0.0311 & 0.1448 \\
Eigen values & 0.225 & 0.107 \\
Species-environment correlations & 0.983 & 0.953 \\
Cumulative percentage variance of species- & 48.4 & \\
environment relation & & 71.4 \\
\hline
\end{tabular}

*Nominal refers to the variables measured in a nominal scale, whereas interval indicates the variables measured in an interval scale (given in range); $\mathrm{EC}=$ Electric Conductivity; N (Nitrogen); P (Phosphorus); Eigen values: are measures of separation of the species distributions along the ordination axis. 



\section{CHAPTER 5}

Adaptability of two weevils (Neochetina bruchi and Neochetina eichhorniae) with potential to control water hyacinth in the Rift Valley of Ethiopia

Y. Firehun, P.C. Struik, E.A. Lantinga and T. Taye (2015)

Crop Protection 76: 75-82 


\begin{abstract}
Neochetina weevils have potential as biocontrol agents for the aquatic weed water hyacinth in Ethiopia, a weed which seriously affect irrigation water supply in sugarcane, vegetables and other horticultural crop production. A study was conducted on (i) the adaptability and duration of developmental stages of Neochetina weevils and (ii) the damage they cause to water hyacinth in the Rift Valley of Ethiopia. The Rift Valley weather conditions appeared to be suitable for the two weevil species studied, enabling them to produce four generations per year. The egg hatching period of Neochetina bruchi ranged from 4 to 10 days, while $N$. eichhorniae took 8 to 12 days. Larvae of $N$. bruchi took a comparatively shorter period (32-38 days) than $N$. eichhorniae (52-60 days) to complete their development. Neochetina bruchi laid a maximum of 10.4 eggs female ${ }^{-1}$ day $^{-1}$, whereas $N$. eichhorniae laid 8.2 eggs female $^{-1}$ day $^{-1}$. The intrinsic rate of increase of $N$. bruchi appeared to be 0.06 with a generation time of 74.8 days and a population doubling period of 14.3 days. The intrinsic rate of increase of $N$. eichhorniae was 0.046 accompanied by a generation time of 94.8 days and a doubling period of 18.7 days. Feeding by adult weevils and tunnelling by larvae significantly impacted the vigour and reproduction of water hyacinth plants. Neochetina bruchi and N. eichhorniae affected plants had about $72 \%(76 \%)$ and $66 \%$ $(58 \%)$ reduction in fresh (and dry) weight, respectively. Thus, based on their damage potential and difference in rate of population growth, it is concluded that N. bruchi could be considered as a promising candidate for biological control of water hyacinth under Ethiopian conditions.
\end{abstract}

Keywords: Aquatic weeds, biology, herbivory, insect-plant interactions, intrinsic rate, population dynamics 


\subsection{Introduction}

Water hyacinth (Eichhornia crassipes [Mart.] Solms) is a serious and persistent aquatic weed that has become naturalized in many areas of the world. In the absence of its natural enemies, it also became a dominant floating weed in water ways and lakes in Africa (Cilliers et al., 2003). In Ethiopia, this weed was reported about 60 years ago in Koka Lake and the Awash River (Firehun et al., 2013). Water hyacinth infestation is now present in many water bodies in the country (Firehun et al., 2014).

Firehun et al. (2007) reported that the sugarcane plantation of Wonji-Shoa spent a total of US\$28,000 over four years to manage this weed. In addition, it caused water loss ranging between 393,660 and 2,945,160 $\mathrm{m}^{3}$, an amount that could have irrigated up to 231 ha year ${ }^{-1}$. Water hyacinth also restricted irrigation water flow and created favourable conditions for the breeding of the malaria mosquito (Julien, 2001). An integrated use of herbicidal and mechanical control measures implemented in WonjiShoa sugar factory resulted in better control of the weed than physical control measures especially in the reservoirs, irrigation supplies and drainage systems (Dula et al., 2008). However, the management was not possible to ensure these results, because of reinfestation from upstream water bodies (starting from Aba Samuel Dam to Koka Dam) remained contaminated with this noxious aquatic weed. A recent survey in the Rift Valley of Ethiopia confirmed that this noxious aquatic weed has a wide distribution from the source Aba Samuel Lake down to the Rift Valley water bodies (Firehun et al., 2013).

Biological control of water hyacinth is the preferred method of control. It is environmentally friendly and has successfully reduced infestations in many African countries (Hill et al., 1999; Cilliers et al., 2003; Mbati and Neuenschwander, 2005). Among the seven arthropod agents released worldwide (Harley, 1990; Julien et al., 1999, Tipping et al., 2010, 2014), two weevils, Neochetina eichhorniae (Warner) and N. bruchi Hustache (Coleoptera: Curculionidae), are the most effective (DeLoach and Cordo, 1976a; Center and Van, 1989; Center et al., 1999b). These two weevil species have been released on water hyacinth in 30 ( $N$. bruchi) and 27 ( $N$. eichhorniae) countries, respectively (Center et al., 2002). These weevils are host specific and successful biological agents used for the control of water hyacinth. For example, in Uganda, the impact of the two weevils five years after release indicated that in Lake Victoria there was a rapid build-up of the weevil population that reduced the weed biomass by nearly $80 \%$ (Ogwang and Molo, 2004). These results were also later repeated on the Kenyan and Tanzanian shores of Lake Victoria (Mallya et al., 2001; Ochiel et al., 2001). Similarly, in Benin, the weevils were shown to reduce water hyacinth cover from 100 to $5 \%$ within eight years (Ajuonu et al., 2003). In Egypt, $N$. 
eichhorniae and N. bruchi were released in August 2000 on two lakes and by July 2002, water hyacinth on Lake Edko was reduced by 90\% (Cillers et al., 2003). There has also been success in other areas of the world including Mexico where $20-80 \%$ reduction of the water hyacinth population has occurred within 2-3 years after release of the weevils (Aguilar et al., 2003).

The relative adaptability and success of these weevils in controlling water hyacinth differ from place to place and from country to country. For example, in Benin, $N$. eichhorniae is better adapted than N. bruchi (Ajuonu et al., 2003), while in Uganda, $N$. bruchi became the dominant species (Ogwang and Molo, 2004).

Climate matching between Ethiopia and those tropical regions in Africa where the weevils proved to be a success, such as Uganda, Sudan, and Benin, indicated the potential to use these weevils as biocontrol agents for water hyacinth in Ethiopia (Firehun et al., 2013). Accordingly, in the biological control programme of water hyacinth, $N$. eichhorniae and $N$. bruchi were imported into the country from the Biological Control Unit, Namuloge Agricultural and Animal Production Research Institute based in the Republic of Uganda.

However, to release these weevils into water hyacinth infested and prone areas, it was crucial to generate basic information such as their adaptability, life cycle and developmental stage duration. Therefore, this study was aimed at determining the adaptability and duration of developmental stages of the Neochetina weevils in the Rift Valley of Ethiopia. In addition, the damage the weevils do to water hyacinth was also assessed.

\subsection{Materials and methods}

\subsubsection{Description of the study area}

Wonji-Shoa is located in the central part of the East African Rift Valley at $8^{\circ} 30^{\prime}$ to $8^{\circ} 35^{\prime} \mathrm{N}$ longitudes and $39^{\circ} 20^{\prime} \mathrm{E}$ latitude and at an altitude of $1540 \mathrm{~m}$ a.s.l. It receives an average of $831 \mathrm{~mm}$ annual rainfall with a bimodal distribution (between mid MaySeptember and February-April). The mean minimum and maximum temperature are $15^{\circ} \mathrm{C}$ and $27^{\circ} \mathrm{C}$, respectively.

\subsubsection{Mass rearing of Neochetina weevils at Wonji research station}

The two Neochetina weevil species (i.e., 100 adult weevils from each species) were imported from Uganda following the quarantine procedures of the country. Rearing weevils at Wonji research station involved propagating seven to ten water hyacinth plants in a plastic basin placed in water. Two hundred plastic basins each with 30 litres capacity were used for the rearing of the weevils. The tanks were arranged at 0.025 
metre apart within a lath house (an outdoor structure that is covered with insect proof plastic net which allows light to penetrate to the plants). Each basin was covered with greenhouse shade cloth $(40 \%$ light $)$ to prevent escape of the insects. Prior to introducing the weevils, the tanks were filled with water up to $75 \%$ capacity and selected healthy water hyacinth plants were placed in each tank and acclimatized for a month. Once in a month, NP fertilizer $\left(50 \mathrm{mg} \mathrm{l}^{-1} \mathrm{~N}\right.$ and $\left.2.5650 \mathrm{mg} \mathrm{l}^{-1} \mathrm{P}\right)$ was added to each basin to enhance the plant growth following the procedure of Ogwang and Molo (1997).

From the stock of adult weevils imported, six to eight pairs of the adults were released in each basin having seven acclimatized water hyacinth plants. Then the weevils were allowed to feed, mate and lay eggs on the water hyacinth plant in the respective basins for at least 4 days (Julien et al., 1999). After 3-4 days, the adult weevils that had infested the plant were collected and transferred to other uninoculated basins containing water hyacinth plants. During the course of mass rearing, regular cleaning of each plant in each basin was done by removing dead lower leaves and reducing the fibrous root to a reasonable size (i.e., $15-20 \mathrm{~cm}$ ).

The two species were reared in separate tanks. Each tank was covered with greenhouse shade cloth (40\% light) and clearly marked with the name of the species and the date of introduction. The newly hatched larvae were harvested and used in these studies.

\subsubsection{Life cycle and development of Neochetina weevils}

\subsubsection{Egg to larva duration}

Three sets of nine $500 \mathrm{ml}$ plastic containers were arranged in a complete randomized design with three replications in the laboratory to investigate the egg to larva duration for each weevil species ( $N$. bruchi and $N$. eichhorniae). For this study, sets of 10 freshly laid eggs less than 24 hours were collected from mass rearing tanks and transferred onto a $2 \mathrm{~mm}$ water hyacinth petiole discs. Hundred $\mathrm{ml}$ of water was added to avoid desiccation. The sets were held at $25{ }^{\circ} \mathrm{C}$ and checked daily for hatching until no further hatching was observed. Data on the number of eggs hatched and duration (days) from egg to larva period of incubation were collected.

\subsubsection{Larva to pupa duration}

To study the developmental period from larva to pupa of the two weevils, three sets of nine 20 litre plastic buckets were filled up to 75\% with water. One healthy water hyacinth plant was placed in each bucket. Sets of ten eggs borne on $2 \mathrm{~mm}$ petiole discs were collected from the respective species rearing tanks. The discs were then inserted 


\section{Chapter 5}

at mid length of the plant's petioles using sterile scalpels to make the incision. Each bucket was then covered with an insect proof muslin cloth mounted on a $100 \mathrm{~cm} \times 100$ $\mathrm{cm}$ wooden cage. This experiment was arranged in a complete randomized design with three replications and was conducted in an open-air laboratory at Wonji. Data on the duration (days) from the first instar larvae to pupal formation were recorded to give the larval development period.

\subsubsection{Pupa to adult duration}

Pupal stage of these weevils occurs in the submerged roots of the plant. To study the developmental period from pupa to adult for the two weevil species, two sets of nine $500 \mathrm{ml}$ plastic containers were arranged in a complete random design with three replications. In each container, 10 full-grown larvae inside the root-balls were attached to the roots of water hyacinth plant and transferred to the containers (DeLoach and Cordo, 1976b). The containers were covered with an insect proof muslin cloth and duration (days) taken from pupa to adult emergence was recorded.

Finally, during data analysis, total egg counts were log-transformed before subjecting them to the analysis of variance to ensure normality of the data. The number of days required for egg hatching, larval and pupal development, adult emergence and adult longevity were analysed using one-way analysis of variance via a general linear model (PROC GLM, SAS Institute, 2008 computer package. Whenever the F-test was significant, least significant difference (LSD) was used for mean separation.

\subsubsection{Reproductive potential and population increase}

The two weevils were acquired from the colony of the $3^{\text {rd }}$ generation reared on the water hyacinth plant acclimatized on basins at Wonji. Eggs obtained from the weevils were inoculated into the mass rearing containers and reared on the same diet. Insect rearing and all experiments were conducted at the Wonji sugarcane research center crop protection laboratory facilities at a temperature of $25{ }^{\circ} \mathrm{C}$. Insects of the $3^{\text {rd }}$ generation reared in our laboratory were used for this study. The sex ratio (female:male) of this generation was about 1:1, which was used for calculations in the present study.

To estimate the reproductive capacity and population increase of the two weevils, we confined twenty sexed pairs of weevils $<48 \mathrm{~h}$ old, for the duration of their lifespan, in $500 \mathrm{ml}$ plastic containers and provided them with three water hyacinth leaves and a $5 \mathrm{~cm}$ long bulbous petiole for feeding and egg laying, respectively. To avoid desiccation, $100 \mathrm{ml}$ of water was added to each container. The containers were covered with muslin cloth to exclude other insects. Egg masses were collected and 
counted daily from each pair. Egg fertility was determined by observing six to nine days old eggs under a dissecting microscope (Olympus SZ III, Japan) using under stage transmitted light. Eggs with black dots (larval head capsules) were recorded as fertile. Adult mortality was recorded daily. Day 70 and 90 were considered to be the first day for adult $N$. bruchi and $N$. eichhorniae, respectively.

The life table of the two weevils was constructed based on the guidelines given by Birch (1948), Evans and Smith (1952), Howe (1953) and Leslie and Park (1949). The intrinsic rate of natural increase $\left(r_{m}\right)$ was determined by the equation:

$$
\sum e^{-r_{m} x} l_{x} m_{x}=1
$$

where, ' $\mathrm{e}$ ' is the base of natural logarithm, ' $x$ ' is the age of individuals in days, $l_{x}$ is the number of individuals alive at age $x$, as a proportion of 1 and $m_{x}$ is the number of female off-springs produced per female in age intervals $x$. The sum of products of $l_{x}$ and $m_{x}$ was regarded as the net reproductive rate (indicating that one living female egg would be, on average, replaced by $R_{o}$ living daughter eggs).

$$
\left(R_{o}=\sum l_{x} m_{x}\right)
$$

Practically, the time interval between the birth of a parent and the birth of a parent's offspring is referred to as the generation time. However, the generation time is different for each individual parent, so theoretically the value of cohort generation time $\left(T_{c}\right)$ was calculated by the equation (Evans and Smith, 1952):

$$
T_{c}=\sum \frac{x l_{x} m_{x}}{R_{o}}
$$

The definite rate of increase $(\lambda)$ was determined as (natural antilogarithm of $r_{m}$ ).

$$
\lambda=e^{r_{m}}
$$

Finally, the doubling time was calculated by the equation:

$$
\mathrm{DT}=\log 2 / \log \lambda
$$

\subsubsection{Adaptability study of Neochetina weevils at Wonji research station}

An in vivo study was conducted to assess population dynamics of the two weevils. The study was conducted under outdoor condition in the lath house located within the Wonji research station facility. The lath house was partitioned in to two compartments so as to keep the two species separate. Prior to introducing the weevils, the tanks were filled with water up to $75 \%$ capacity and selected healthy water hyacinth plants were 
placed in each tank and acclimatized for a month. Samples were taken from June 2011 through August 2013 on a weekly basis from 60 basins per species replicated three times. Every two months, an equal number of new water hyacinth plants was added to the respective plots. In this experiment, three basins were considered as a plot. At each plot three random pairs of adjacent samples $(0.05 \times 0.05 \mathrm{~m})$ were collected. One sample of each pair was used to determine plant biomass; the other was used to determine insect density and the last one was used to determine the feeding scar per plant. This sampling procedure was repeated at each replication.

Plants from each sample were counted and weighed to determine density (number of plants $\mathrm{m}^{-2}$ ) and total biomass $\left(\mathrm{kg} \mathrm{m}^{-2}\right)$. The number of feeding scars per plant per leaf was also recorded. All plants from one of the $0.0025 \mathrm{~m}^{2}$ samples were carefully examined for larvae, pupae, and adults of the two weevil species. Individuals of each life stage were counted. Adults were separated to species and sex. Weevil intensity or numbers per unit plant were also determined by dividing the total number of adults by the number of plants.

Sample data from each basin were averaged and subjected to statistical analysis using a randomized complete block design; i.e. each basin mean represented one block value. Before analysis, all sample measurements were presented per plant basis. Adaptability of the weevils was determined using analysis of variance (ANOVA) procedures. Means separation was done using a least significant difference (LSD) test calculated from the pooled standard error of the mean. Regression analysis was used to quantify linear trends. All analyses were done on the statistical analysis system using the general linear model or regression procedures (SAS Institute, 2008). Graphs of the numbers of adults and larvae were plotted to determine population trends and the number of generations per year.

\subsection{Results and discussion}

\subsubsection{Life cycle and development of Neochetina weevils}

\subsubsection{Egg stage}

Eggs of N. bruchi and N. eichhorniae were white when first laid but changed to pale orange as they approached to hatching. The eggs were arranged singly or in a group inserted below the epidermal layer of a petiole. The egg hatching period for N. bruchi ranged from 4 to 10 (mean $=6.7 \pm 2.4$ ) days while for $N$. eichhorniae it ranged from 8 to 12 (mean $=9.0 \pm 1.6$ ) days at an average temperature of $25{ }^{\circ} \mathrm{C}$. In other studies, the egg stage of $N$. bruchi took a shorter duration (7.6 days) in Argentina at $25{ }^{\circ} \mathrm{C}$ (DeLoach and Cordo, 1976b) compared to 11 days in Uganda and Kenya (Nijoka, 
2001; Ogwang and Molo, 1997). Similarly, life cycle study on N. eichhorniae indicated that the egg stage could take 7-14 days in Argentina at $25{ }^{\circ} \mathrm{C}$ (Stark and Goyer, 1983) while it took 10 days in Uganda at 20-24 ${ }^{\circ} \mathrm{C}$ (Ogwang and Molo, 1997) and 14 days in Kenya at $21-24{ }^{\circ} \mathrm{C}$ (Nijoka, 2001). The number of days reported in the present study was relatively small for $N$. bruchi and high for $N$. eichhorniae as compared to the reports of DeLoach and Cordo (1976b) and Stark and Goyer (1983), respectively. The differences could be attributed to variation in temperature. In line with this, reports indicated that temperature had a significant effect on egg hatching period of Neochetina weevils (DeLoach and Cordo, 1976b; Grodowitz et al., 1991; Heard and Winterton, 2000). However, there was no significant difference in the egg to larvae durations between the two weevil species.

\subsubsection{Larval stage}

Both weevil species had three larval instars. The number of days required for the development of larvae showed significant differences $(\mathrm{P}<0.05)$ among the three stages and between the two species (Table 5.1). Larvae of N. bruchi took comparatively shorter period (32-38 days, mean $34.4 \pm 2.8$ days) to complete their developmental stage than $N$. eichhornaie. Duration of $N$. bruchi $1^{\text {st }}, 2^{\text {nd }}$ and $3^{\text {rd }}$ instars development on average took $11.6 \pm 1.3$ (range, 10-13 days), $14.9 \pm 1.4$ (range, 14-17 days) and $8.1 \pm 1.2$ days (range, 6-9 days), respectively. Whereas, $1^{\text {st }}, 2^{\text {nd }}$ and $3^{\text {rd }}$ instar larvae of $N$. eichhorniae took on average $17.6 \pm 1.3$ (range, 16-19 days), $25.1 \pm 1.2$ (range, 23-29 days) and 13.6 \pm 4.4 days (range, 9-20 days), respectively. Neochetina eichhorniae took 52 to 60 days (mean $=56.3 \pm 3.0$ ) to complete their developmental stage. The larval developmental period in this study was very similar to the works of Ogwang and Molo (1997) that indicated larvae of N. bruchi and N. eichhornia took on

Table 5.1. Developmental time of N. bruchi and N. eichhorniae from egg to pupal stage.

\begin{tabular}{lrcc}
\hline & \multicolumn{2}{c}{ Mean duration (day) \pm SE } & \\
\cline { 2 - 3 } Developmental Stage & N. bruchi & N. eichhorniae & Significance \\
\hline Egg to larva & $6.7 \pm 2.4$ & $9.0 \pm 1.6$ & $\mathrm{~ns}$ \\
Larvae & $34.4 \pm 2.8$ & $56.3 \pm 3.0$ & $* *$ \\
1st Instar & $11.6 \pm 1.3$ & $17.6 \pm 1.3$ & $* *$ \\
2nd Instar & $14.9 \pm 1.4$ & $25.1 \pm 1.2$ & $* *$ \\
3rd Instar & $8.1 \pm 1.2$ & $13.6 \pm 4.4$ & $*$ \\
Pupae & $29.4 \pm 3.7$ & $27.4 \pm 4.6$ & $\mathrm{~ns}$ \\
Adult longevity & $116 \pm 7.3$ & $133 \pm 9.2$ & $* *$ \\
\hline
\end{tabular}

Where $\mathrm{ns}=$ not significant, $*=$ significant at $\mathrm{P}<0.05$, and $* *=$ significant at $\mathrm{P}<0.01$. 
average 35 and 58 days compared with that reported by DeLoach and Cordo (1976b) and Stark and Goyer (1983). The larval duration also took 31 and 57 days in Kenya (Nijoka, 2001), which is similar with the present finding. The variation in the developmental period may be due to the difference in adaptations to the climatic condition (i.e., mainly to the prevailing temperature).

It is apparent that the larva causes the most damage to the water hyacinth plant through tunnelling the petioles ultimately leading to the death of the plant. In line with this, observation on larval feeding habit of the two weevils reared under lath house condition showed that larva of the two weevils fed first within the petiole tissues, and then mined towards the base of the plant. Most of the larvae were found singly, however, in some large larval tunnels 2-4 larvae were observed together. In some cases, though the tunnel length was high, only single larvae had been observed. After completion of the $3^{\text {rd }}$ instar, the larvae came out of the petiole and moved into the root. This tunnelling potential coupled with the difference in the larval developmental period between the two species indicates the potential for combined use of the two species in large scale management of water hyacinth.

\subsubsection{Pupal stage}

No significant difference was observed between the two species in the pupation period. Duration of pupal stage ranged from 24 to 34 days (mean $=29.4 \pm 3.7$ days) and from 22 to 30 (mean $=27.4 \pm 4.6$ days) for $N$. bruchi and N. eichhorniae, respectively at a temperature of $25-27{ }^{\circ} \mathrm{C}$, under lath-house condition. Similarly, in Uganda, pupal stage took 30 and 28 days for the two weevils at $21-25^{\circ} \mathrm{C}$, respectively (Ogwang and Molo, 1997). On the other hand, DeLoach and Cordo (1976b) reported that $N$. bruchi required a pupation period of 30 days at $25^{\circ} \mathrm{C}$. In Kenya, this stage took 31 and 28 days respectively for $N$. bruchi and $N$. eichhorniae at $21-24{ }^{\circ} \mathrm{C}$ (Nijoka, 2001).

\subsubsection{Adult longevity}

Adult longevity ranged from 80 to $130($ mean $=116 \pm 7.3)$ and 90 to $160($ mean $=133$ \pm 9.2 ) days for $N$. bruchi and N. eichhorniae, respectively for both sexes (Table 5.1). In India, Jayanth (1988) reported that adult longevity of N. bruchi and N. eichhorniae could take an average of 134 and 142 days. DeLoach and Cordo (1976b) reported a maximum of 87 days for $N$. bruchi. A study conducted in Kenya indicated that the adults of the two weevils would live on average for about 112 days (Nijoka, 2001). Thus, the higher longevity recorded in the present study as compared to Argentina and Kenya indicates the prevalence of conducive climatic condition, which consequently enhanced the potential for use of the two weevils to control water hyacinth. 


\subsubsection{Reproductive potential and population increase}

The reproductive potential and population increase of the two weevils indicated that there was a slight difference between the two weevils. Among the two weevils, $N$. bruchi females oviposited a total of $359 \pm 14.4$ eggs $($ mean $=189 \pm 34.3$ ) in their lifespan.

The first eggs were laid one day after emergence, after which time daily fecundity increased rapidly from 5.2 females female ${ }^{-1}$ day $^{-1}$ to the maximum of 10.4 females female $^{-1}$ day $^{-1}$ on the $35^{\text {th }}$ day and declined to $3.70 \pm 0.73$ eggs female ${ }^{-1}$ day $^{-1}$ (Table 5.2). About $50 \%$ of the total eggs were laid within 16 days after emergence, and more than $85 \%$ of eggs were oviposited when more than $50 \%$ of females were alive (Figure 5.1). The oviposition potential observed in this study was higher than that of DeLoach and Cordo (1976b) finding where $N$. bruchi oviposited during the first three days after emergence and laid on average 5 eggs day $^{-1}$ in the first week, which later declined rapidly to an average of ca. 1.5 eggs female ${ }^{-1}$ day $^{-1}$.

The intrinsic rate of natural increase $\left(r_{m}\right)$ of $N$. bruchi was $0.060 \pm 0.003$ females female $^{-1}$ day $^{-1}$. From this value, a finite rate of increase $(\lambda)$ was determined as 1.06 female female ${ }^{-1}$ day $^{-1}$. The result indicated that $N$. bruchi had a capacity to multiply 92 times $\left(R_{o}\right)$ in every generation. This result agreed with the findings of DeLoach and Cordo (1976b) who reported $r_{m}=0.057$, and for generation time ( $\mathrm{T}=96.4$ days), population increase $\left(\lambda=1.058\right.$ times day $\left.{ }^{-1}\right)$, and doubling time (DT $=12.2$ days).

Table 5.2. Life history parameters of $N$. bruchi and N. eichhorniae.

\begin{tabular}{llcc}
\hline Parameters & Unit & N. bruchi & N. eichhorniae \\
\hline Net reproductive rate $\left(R_{o}\right) *$ & Female female $^{-1}$ & $92 \pm 5.6$ & $83 \pm 4.3$ \\
Gross reproductive rate, GRR* & Female female $^{-1}$ & $101 \pm 6.3$ & $85 \pm 5.0$ \\
Mean generation time $(\mathrm{T}) *$ & Days & $75 \pm 2.3$ & $95 \pm 1.6$ \\
Intrinsic rate of increase $\left(r_{m}\right) *$ & Head $^{-1}$ day $^{-1}$ & $0.060 \pm 0.003$ & $0.046 \pm 0.002$ \\
Doubling time $(\mathrm{DT}) *$ & Days $^{*}$ & $14.400 \pm 1.79$ & $18.6 \pm 1.84$ \\
Finite rate of increase $(\lambda) *$ & Times day $^{-1}$ & $1.062 \pm 0.011$ & $1.047 \pm 0.003$ \\
Fecundity for the first 35 days* & Egg female $^{-1}$ day $^{-1}$ & $6.800 \pm 0.82$ & $6.000 \pm 0.740$ \\
& Egg female $^{-1}$ day $^{-1}$ & $3.700 \pm 0.73$ & $3.100 \pm 0.540$ \\
\hline
\end{tabular}

Note: $\mathrm{t}$-test was performed for all the parameters; * indicate significance at $5 \%$ probability level; $\mathrm{n}=20$. 


\section{Chapter 5}

The result indicated that $N$. eichhorniae females oviposited $299 \pm 35.8$ eggs (mean $=145 \pm 63.6)$ in their lifespan. Similar to that of N. bruchi, the first eggs were laid 1 day after emergence, after which time daily fecundity increased rapidly from 4.3 females female ${ }^{-1}$ day $^{-1}$ to the maximum of 8.2 females female $^{-1}$ day $^{-1}($ mean $=5.7)$ on the $15^{\text {th }}$ day (Figure 5.1). Substituting these values into the equation of Birch (1948) gave $r_{m}$ value 0.046 and generation time (T) 94.9 days. Therefore, the population would increase 1.047 times day ${ }^{-1}$ and 18.6 days would be required for the population to double. The average daily female living throughout the entire reproductive period (Gross reproductive period) was 84.5 females female ${ }^{-1}$. The average daily output of daughter eggs by such female was 3.1 eggs. The study also confirmed that on average, one female egg alive would be replaced by approximately 83 live daughter eggs $\left(R_{o}\right)$, which was 83 -fold increase per generation.
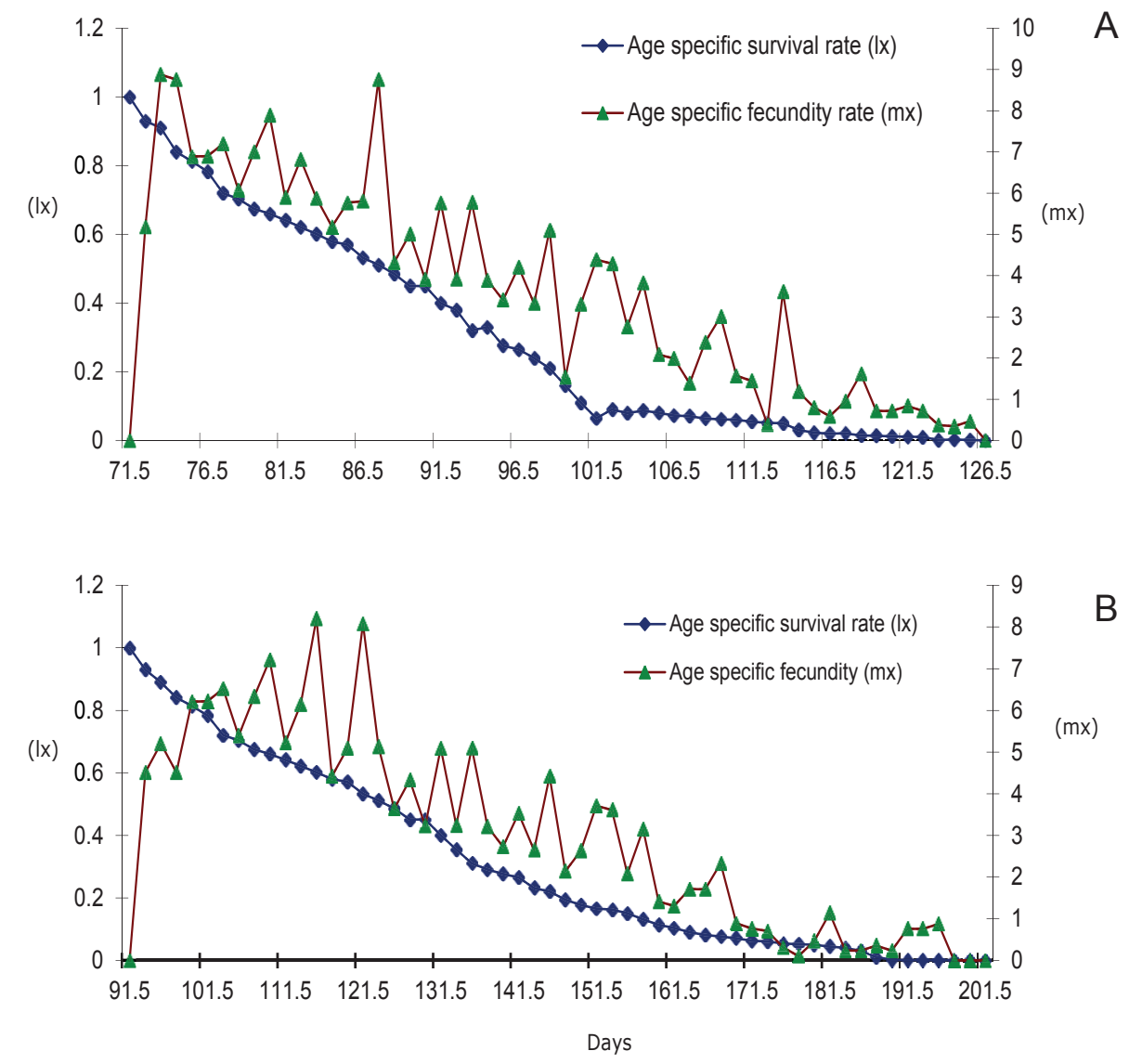

Figure 5.1. Age specific survival and fecundity of $N$. bruchi (A) and N. eichhorniae (B) under laboratory conditions. 
The fecundity (358 and 298 eggs female ${ }^{-1} ; N$. bruchi and N. eichhorniae) reported in this study was very similar to that of wild $N$. eichhorniae and within the range for laboratory colonies (DeLoach and Cordo, 1976b; Bashir et al., 1984; El Abjar and Bashir, 1984; Harley, 1990; Ogwang and Molo, 1997; Nijoka, 2001). Our finding showed that $N$. bruchi also had a higher oviposition rate per day compared to $N$. eichhorniae. Based on these fecundity factors, it seems logical to infer that $N$. bruchi is a more prolific producer of eggs than $N$. eichhorniae in the area under study.

The generation time (T) was 74.8 and 94.8 days for $N$. bruchi and N. eichhorniae, respectively (Table 5.2). Generation time for $N$. bruchi was observed to be 96, 72, and 73 days in Argentina, Uganda and Kenya while N. eichhorniae took 120, 96 and 94 days, respectively (DeLoach and Cordo, 1976b; Jayanth, 1988; Harley, 1990; Ogwang and Molo, 1997). The two weevils took shorter generation time in Ethiopia than in Argentina but relatively similar with the two East African countries. Insects with a shorter generation time produce more larvae and adults (the destructive stage) from several generations in a year than the insects with long generation time. This, coupled with the high egg laying capacity (fecundity), is an important factor in the choice of a biological control agent (Harley, 1990). This indicates the existing potential for large scale application of these bioagents under Ethiopian conditions.

The potential growth of the two weevils' population was also determined by the age of the female at the commencement of oviposition and the intensity of oviposition during the first few days of the oviposition period. In this study, more than $85 \%$ of eggs were laid during the first few days where $75 \%$ of females were still alive. This indicates by concentrating reproductive effort in the early days of adult stage, the two weevils maximize their ability to build large populations, as the mortality of the older females will have little influence on the population growth. As Birch (1948) pointed out, the earlier the oviposition effort is, the greater its contribution to the $r_{m}$ value will be. However, late oviposition would enable the weevils to maintain the population in unfavourable conditions such as climatic changes. In general, the present study showed enhanced reproductive performance of the two weevils as reflected in their quicker development $\left(R_{o}\right)$, higher survival and higher fecundity, particularly in the earlier adult life.

\subsubsection{Adaptability study of Neochetina weevils}

Population of $N$. eichhorniae and $N$. bruchi increased over time as indicated by adult numbers and corresponding increase in feeding scars per plant (Figures 5.2 and 5.3). Adult numbers changed significantly over time ( $N$. bruchi: $\mathrm{F}=4.79 ; \mathrm{P}=0.0002$, $\mathrm{R}^{2}=0.73$ Figure 5.2; N. eichhorniae: $\mathrm{F}=3.62 ; \mathrm{P}=0.0014 ; \mathrm{R}^{2}=0.82$ Figure 5.3). For example, the highest number in 2011 occurred three months after release of the well 


\section{Chapter 5}

quarantined weevils during the main rainy season with values of mean individuals of four weevils plant ${ }^{-1}$ in October 2011. Thereafter, a significant decrease in adult numbers followed and the numbers continued to decline to November and December. The lowest values for each species (mean $=0.5$ individuals plant $^{-1}$ ) were recorded between November and December 2011 following the low temperatures. In January and February 2011, a significant linear increase ( $N$. bruchi: $\mathrm{P}=0.0018 ; \mathrm{R}^{2}=0.94 ; N$. eichhorniae: $\mathrm{P}=0.0088 ; \mathrm{R}^{2}=0.86$ ) of about 4 individuals plant ${ }^{-1}$ month $^{-1}$ species $^{-1}$ (i.e., N. bruchi and N. eichhorniae) was noted, respectively. Adult numbers increased more widely during the 2012 and 2013 growing season. Peak populations of approximately 5.6 and 7.4 individuals plant $^{-1}$ were recorded in August 2012 and March 2013 for $N$. bruchi while 5.9 and 6.9 individuals plant $^{-1}$ were noted in October 2012 and April 2013 for $N$. eichhorniae, respectively. This seasonal variation as well as over year's increment of the weevils population would indicate their adaptability to the Rift Valley agro-climatic conditions.

The present study also confirmed that the two weevils produced four generations per year. Accordingly, the first generation of $N$. bruchi adults emerged in August, apparently from the first acclimatized larvae and pupae as explained by their populations. Later on populations increased gradually in September and October as more adults emerged from pupae. Similarly, the first generation of $N$. eichhorniae occurred in August and extended to October 2011 as more adults emerged from larvae and pupae. The subsequent peak of pupae occurred in January 2012.

The second generation was recorded in January 2012 and increased in February and March 2012. Large populations of larvae were recorded during the months of February and March. The largest pupae population occurred in March 2012 contributed for the large population of third generation of $N$. bruchi. Finally, the fourth generation of $N$. bruchi was recorded in May 2012. Similarly, the second, third and fourth generation of $N$. eichhorniae were recorded in January, April and June, respectively. The weevils have four generations year ${ }^{-1}$ in Lousiana (Stark and Goyer, 1983), Uganda (Ogwang and Molo, 1997), and Kenya (Nijoka, 2001) whereas they produced three generations in Argentina (DeLoach and Cordo, 1976b).

Records of the effects of $N$. bruchi on plant biomass in 2011 revealed that plant biomass decreased from the fresh weight recorded during June to October; and increased in November and December. A linear decrease $\left(\mathrm{R}^{2}=0.90\right)$ was recorded from January to March 2012 and then there was a slight increase during April and May. In June and July 2012, the plant biomass showed a decreasing trend followed by an increase at an alarming rate from September to December. Similar effects were also recorded in 2013. 


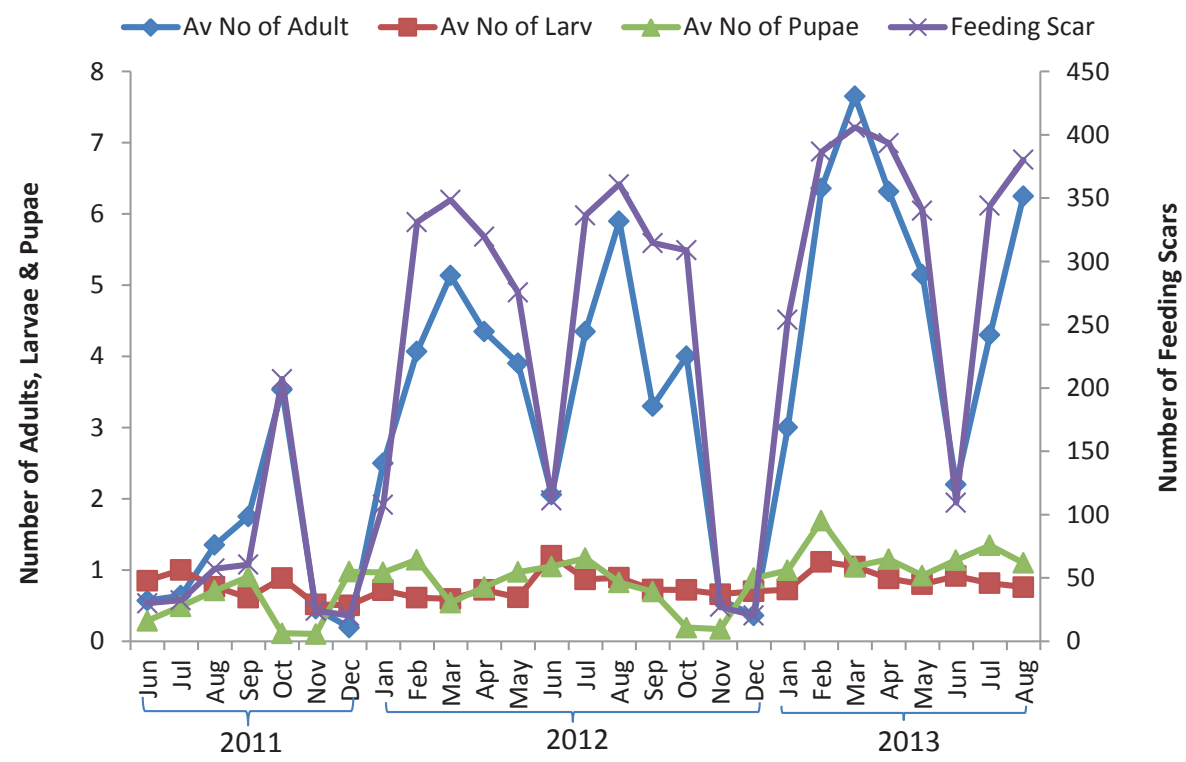

Figure 5.2. Density of $N$. bruchi adults, larvae as well as pupae and feeding scars per plant through time at Wonji-Shoa, Rift Valley, Ethiopia. Lsd (Average number of adults) $=0.23$; Lsd (Average number of larvae) $=0.07$; Lsd (Average number of pupae) $=0.07$ and Lsd (feeding scars) $=75.41$ at $\mathrm{P} \leq 0.05$.

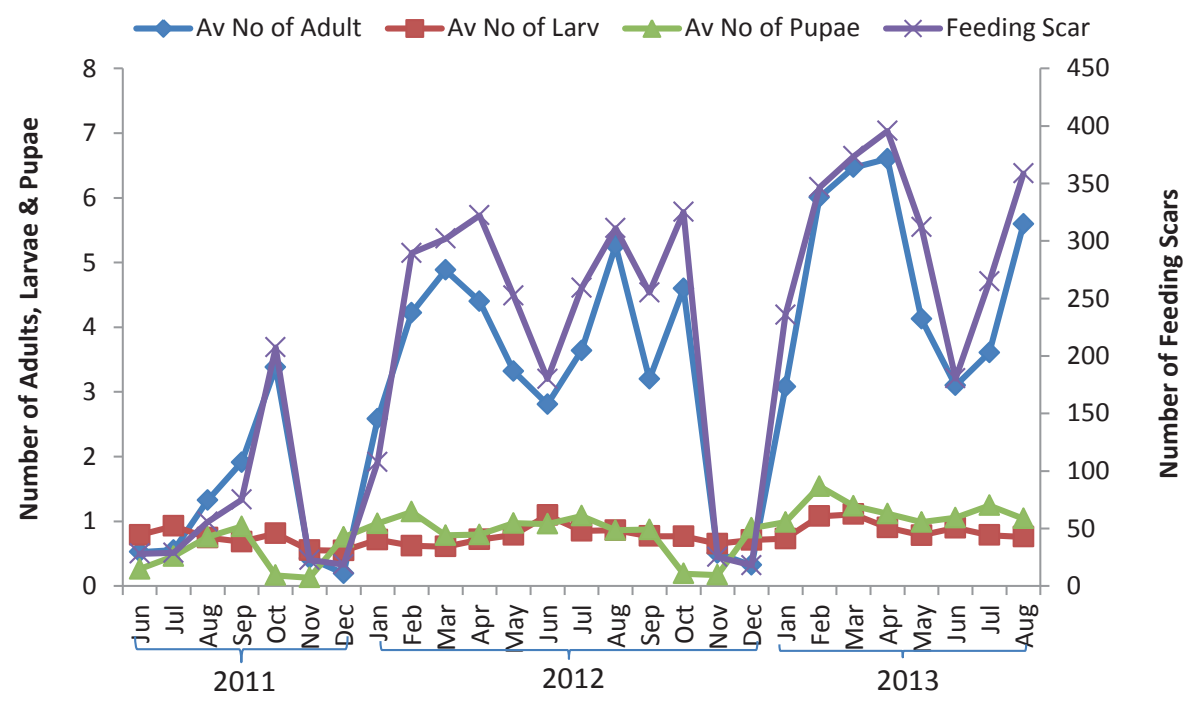

Figure 5.3. Density of $N$. eichhorniae adults, larvae as well as pupae and feeding scars per plant through time at Wonji-Shoa, Rift Valley, Ethiopia. Lsd (Average number of adults) = 1.23; Lsd (Average number of larvae $)=0.14$; Lsd $($ Average number of pupae $)=0.23$ and Lsd (feeding scars) $=80.11$ at $\mathrm{P} \leq 0.05$. 


\section{Chapter 5}

Examination on the damage caused by this weevil also showed that the highest biomass was observed in December in the entire study period (mean $=243 \mathrm{~g}$ ) while the highest biomass reduction was observed in February, March and April 2013 (i.e., 67,70 and $68 \%$, respectively).

On the other hand, the damage caused by $N$. eichhorniae showed that the highest biomass was observed in December in all the study periods (mean $=294 \mathrm{~g}$ ) while the highest biomass reduction was observed in October 2012 and April 2013 (i.e., 69 and $72 \mathrm{~g}$, respectively). The effects of $N$. eichhorniae on plant biomass in 2011 revealed that plant biomass was decreased as of August towards October; and increased in November and December. A linear decrease $\left(\mathrm{R}^{2}=0.92\right)$ was recorded from January to April 2012 and then there was a slight increase during May (Figure 5.4).

Further analysis of the effects of the two weevils indicated that, from the 100 randomly selected petiole samples in each month, on average 25 showed a larval tunnel and 18 were infested with weevils' larvae (alive). In some months 4-5 larvae per petiole were recorded. In this study, it was noted that $N$. bruchi larval induced significantly reduced petiole length; fresh and dry weight of the plant (Table 5.3). The average tunnel length was $8.2 \mathrm{~cm}$, and the average length of the affected petiole was

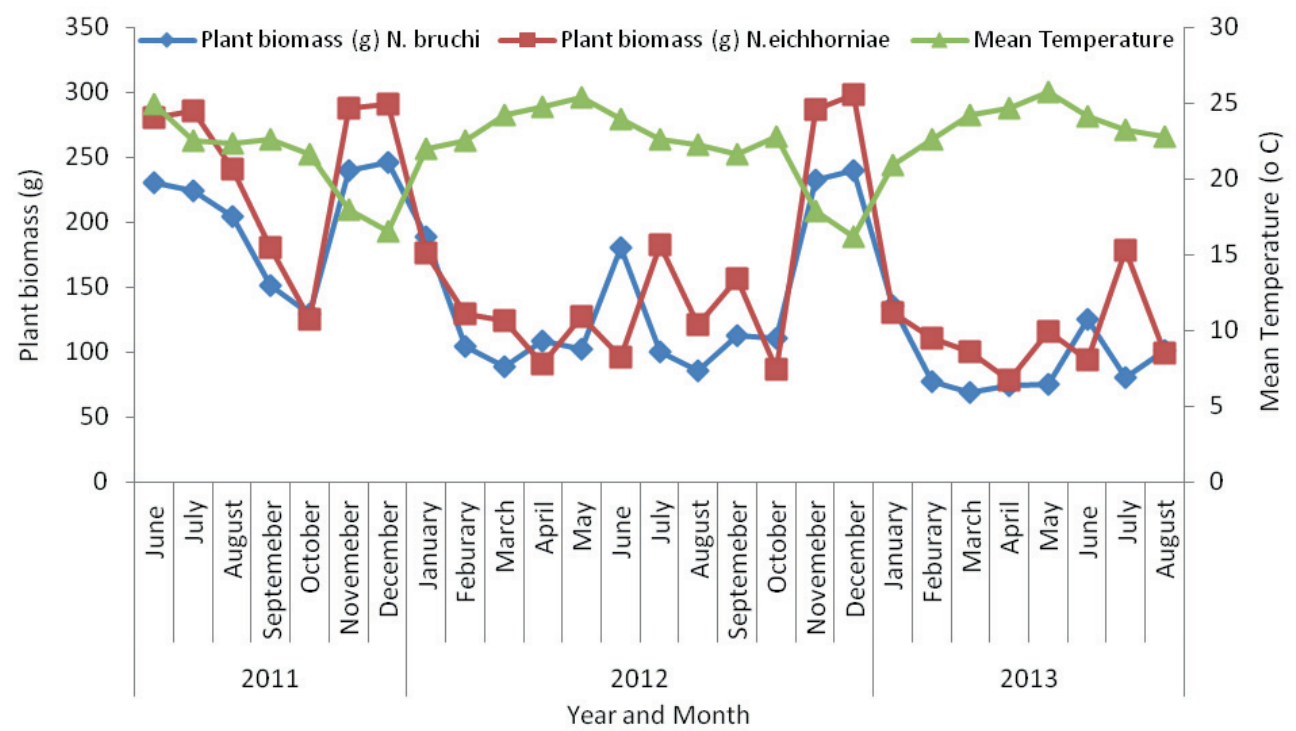

Figure 5.4. Effect of Neochetinia weevils on water hyacinth plant biomass/fresh weight (g) over months. Lsd (Plant biomass, N. bruchi) $=18.3 \mathrm{~g}$; Lsd (Plant biomass, $N$. eichhorniae $)=$ $18.98 \mathrm{~g}$ at $\mathrm{P} \leq 0.05$. 
Table 5.3. Effect of Neochetinia weevils larval tunnelling on water hyacinth petiole length, diameter and weight.

\begin{tabular}{lcccc}
\hline & \multicolumn{4}{c}{ Tunnel length (cm) } \\
\cline { 2 - 5 } Parameters & \multicolumn{3}{c}{ N. bruchi } & N. eichhorniae \\
\cline { 2 - 5 } & 0 & $1.0-14.5 \mathrm{~cm}$ & 0 & $1.0-12.3 \mathrm{~cm}$ \\
$(\mathrm{n}=60)$ & $(\mathrm{n}=40)$ & $(\mathrm{n}=67)$ & $(\mathrm{n}=33)$ \\
\hline Average larval tunnel length per petiole $(\mathrm{cm})$ & - & $8.2^{*}$ & - & $5.5^{*}$ \\
Petiole length $(\mathrm{cm})$ & 26.5 & $15.3^{*}$ & 25.1 & $18.3^{*}$ \\
Petiole diameter $(\mathrm{cm})$ & 0.07 & $0.03^{*}$ & 0.07 & $0.32^{*}$ \\
Fresh weight $(\mathrm{g})$ & 285 & $78.5^{*}$ & 275 & $93.6^{*}$ \\
Dry weight $(\mathrm{g})$ & 23.8 & $6.3^{*}$ & 24.1 & $10.0^{*}$ \\
\hline
\end{tabular}

Note: Two sample t-test assuming unequal variances was performed for tunnel length 1 up to $14.5 \mathrm{~cm}$ ( N. bruchi) and 12.3 ( N. eichhorniae) against the control (tunnel length zero); * indicates significance at $5 \%$ probability level; $\mathrm{n}=$ number of samples.

about $42 \%$ less than that of the non-affected petiole. Moreover, N. eichhorniae larvae induced an average larval tunnel length of $5.5 \mathrm{~cm}$ and the average length of affected petioles was about $27 \%$ less than the non-affected petioles. In agreement with this, Forno (1981) reported that weevils attack significantly affect the number of leaves/plant and petiole diameter.

\subsection{Conclusion}

Seasonal variation as well as over year's increment of the weevils populations confirmed adaptability of $N$. bruchi and $N$. eichhorniae to the Rift Valley agro-climatic condition. However, from the two weevil species, $N$. bruchi showed a higher rate of population growth and caused more plant damage. This indicates $N$. bruchi could be considered as a promising candidate for biological control of water hyacinth under Ethiopian conditions.

\section{Acknowledgements}

We acknowledge EIAR-UNEP-GEF and Ethiopian Sugar Corporation for funding this research work. We are grateful to Namuloge Agricultural and Animal Production Research Institute based in the Republic of Uganda, for the support during importation of the weevils. We also acknowledge Mr Ambachew Dametie, Mr Abiy Negese, and Mr Yohannes Zekarias for the technical support. 

CHAPTER 6

\section{Pre-release evaluation of Neochetina weevils potential for the management of Eichhornia crassipes (Mart.) Solms in the Rift Valley of Ethiopia}

Y. Firehun, P.C. Struik, E.A. Lantinga and T. Taye (2016)

Academia Journal of Agricultural Research 4(7): 394-403 


\begin{abstract}
The present study aimed at evaluating the host specificity, potential efficacy and optimum densities of the two weevils (Neochetina bruchi and N. eichhorniae) as water hyacinth control agents in the Rift Valley of Ethiopia. Density-plant damage relationship was monitored for two years (2012-2014) in a factorial experiment by involving the two Neocthenia weevils and four densities of herbivory. Feeding multiple-choice and oviposition tests were used to assess the two weevils host specificity. The study showed highly significant $(\mathrm{P}<0.01)$ impacts of the two weevils as well as, their interactions on number of ramets, number of leaves, damaged leaf area, petiole length, number of defoliated petioles and biomass of water hyacinth. Damaged leaf area (97\%) and total number of defoliated petioles (2.8) were highest in plants that received three pairs of $N$. bruchi and two pairs of $N$. eichhorniae. The weevil density and water hyacinth biomass showed convex relationship that could be well-described by a negative $\log$ function $\left(\mathrm{R}^{2}=0.98\right)$. The study confirmed that the weevils are sufficiently host specific and, therefore, can be safely released in the Rift Valley of Ethiopia to control water hyacinth.
\end{abstract}

Keywords: Aquatic weeds, herbivory, host specificity, insect-plant interactions, prerelease impact, water hyacinth 


\subsection{Introduction}

Biological control agents introduced into different countries for water hyacinth control include the weevils Neochetina bruchi Hustache and Neochetina eichhorniae Warner (Coleoptera: Curculionidae), the moths Niphograpta albiguttalis Warren and Xubida infusella Walker (Lepidoptera: Pyralidae), the mite Orthogalumna terebrantis Wallwork (Acarina: Galumnidae), and the bug Eccritotarsus catarinensis Carvalho (Hemiptera: Miridae), the planthopper Megamelus scutellaris Berg (Hemiptera: Delphacidae) (Julian and Griffiths, 1998; Tipping et al., 2014). These agents slow down plant growth and reduce water hyacinth densities and plant stature, possibly reducing seed production (Center and Durden, 1986; Center, 1994; Julien et al., 1996; Center et al., 1999a, b). Among these insects, N. eichhorniae and N. bruchi are the most important biological control agents against water hyacinth; they particularly had notable success in the tropics including East Africa (Harley, 1990; Julien and Griffiths, 1998; Julien et al., 1999; Cilliers et al., 2003). In Ethiopia, the need for sustainable control of water hyacinth led to deliberation of effective and climatically adapted classical biocontrol agents. The two Neochetina weevils, N. eichhorniae and N. bruchi, are the most promising candidate agents based on their host specificity, wide natural distribution, adaptability to climatically similar regions in Ethiopia (Firehun et al., 2013), and their recognized damage potential registered in different parts of the world (Julian and Griffiths, 1998). However, undertaking confirmatory host specificity tests was needed, before releases at large scale was allowed. Besides, different findings indicated the need for pre-release efficacy testing as a critical aspect of biocontrol agent studies (Balciunas, 2004; McClay and Balciunas, 2005). A critical goal of such studies in biological control of weeds is to understand how a particular insect herbivore would affect the host plant abundance. Plants are variable in their responses to insect herbivory. Experimental increases in densities of phytophagous insects can reveal the type of plant response to herbivory in terms of impact and compensatory ability (Bownes et al., 2010b).

Understanding the density-damage relationship between the weevils and the water hyacinth plant when used alone and in combination at different densities has a paramount importance to assess the potential impact of the respective weevil species as well as, their synergic effect. In this regard, field evaluation conducted in East and West Africa following the large scale release of the two weevils indicated that there were differences in establishment between the two weevils. For example, in Benin (West Africa), N. eichhorniae was better adapted than N. bruchi (Ajuonu et al., 2003), while in Uganda (East Africa) N. bruchi became the dominant species (Ochiel et al., 2001; Ogwang and Molo, 2004). In contrasts to these situations, the two species of 
Neochetina weevils were equally well established in Congo, Central Africa (Mbati and Neuenschwander, 2005). Thus, determining the density-damage relationship is a very crucial step for initiating large scale release of the two weevils.

Interactions among biocontrol agent, host plant and environment interactions plays a significant role in successful establishment of biocontrol agents and the control of weed. Several limitations of the Neochetina weevils in controlling water hyacinth were reported by some workers (Moran, 2006). One of the most important limitations is the lack of knowledge about the number of weevils required to control the weed in a given area. Researches in South Africa, Argentina, USA and Australia indicated that plant quality affects the life history (Wright and Center, 1984; Center and Durden, 1986; Conlong et al., 2009) and biocontrol potential of the weevils. Such shortcomings of the weevils create favourable environment for water hyacinth to reproduce at a higher rate than the weevil's population growth.

The relationship between the density of the weevils and the water hyacinth plant damage enables to identify optimum synergy of the two weevils with sufficient impact on the water hyacinth to justify release. Therefore, this chapter presents the results of a pre-release impact assessment study on the potential efficacy and host specificity of $N$. eichhorniae and $N$. bruchi with regard to water hyacinth and determines the optimum densities of the two weevils for release in the Rift Valley of Ethiopia.

\subsection{Materials and methods}

\subsubsection{Colony development}

The Sugar Corporation Research and Training Laboratory, in cooperation with the Ethiopian Institute of Agricultural Research, established a rearing site for the two weevils $N$. bruchi and N. eichhorniae. Permission was obtained from the Ministry of Agriculture during 2011 to import both species into Ethiopia. Accordingly, the two weevil species were introduced from the Biological Control Unit, Namuloge Agricultural and Animal Production Research Institute, based in the Republic of Uganda, East Africa. From the stock of adult weevils imported, six to eight pairs of the adults were released in each basin having seven acclimatized water hyacinth plants. Then, the weevils were allowed to feed, mate and lay eggs on the water hyacinth plants in the respective basins at least for 3-4 days. After 3-4 days, the adult weevils which were infested onto the plant were collected and transferred to other uninoculated basins having water hyacinth plants. By doing so, the required number of colonies was developed. 


\subsubsection{Mottled water hyacinth weevils (single density) effectiveness evaluation}

Evaluation of the effectiveness of the weevils was made using plastic basins following the method of the International Institute of Tropical Agriculture (Van Thielen et al., 1994; Ajuonu et al., 2007). A total of 48 plots, each consisting of four plastic basins ( $0.5 \mathrm{~m}$ diameter and $0.30 \mathrm{~m}$ height) were used to raise the water hyacinth plants. Eight plants were placed in each basin. Once the water hyacinth plants in the basins acclimatized, the weevils were inoculated into the plants. At the beginning of the experiment (week 0), the number of plants in each basin was controlled to have uniform number, size and weight. For this evaluation, a total of four treatments were carried out namely: basins that receive $N$. eichhorniae (T1), basins that receive $N$. bruchi (T2), basins that receive equal numbers of both $N$. eichhorniae and $N$. bruchi (T3), and plants which were free of the mottled water hyacinth weevils (control, coded T4). A total of eight pairs of the adults were released per basin having eight acclimatized water hyacinth plants. However, in T3, the populations were composed of two pairs of each species. This experiment was arranged in a complete randomized design (CRD) with three replications and conducted in a lath house. Evaluations were made in weekly intervals for eight consecutive weeks and repeated four times. Duration of the evaluation was maintained only up to eight weeks, which is less than the generation time of the two weevils under Ethiopian condition as determined in the other set of experiments (Firehun et al., 2015).

In the course of the evaluation, data on the number of feeding scars, the total number of leaves, and the number of new plants (ramets) were recorded. Petiole and root length measurements were done at each feeding scar count. During the last examination, five plants were randomly selected from each basin and data on the number of feeding scars, petiole length and root length, number of adults, number of ramets and number of flowers were collected. Besides, live and dead biomass of the weed was measured. For the number of new plants (ramets) data collection, the definition of Center and Spencer (1981) was followed which defines ramets as plants having one open leaf (excluding the primary leaf) and adventitious root initials.

\subsubsection{Host specificity tests}

Two series of experiments namely feeding multiple-choice tests and oviposition tests were conducted at the Sugarcane Research Plant Protection Laboratory.

\subsubsection{Feeding multiple-choice tests}

Two tests were carried out to evaluate the feeding preferences of the two weevils under laboratory conditions. Test plants were selected primarily on the basis of the level of relatedness to the target weed; secondly, on the basis of their economic or 


\section{Chapter 6}

ecological importance, and thirdly on the basis of the degree to which they share the same habitat (Eckenwalder and Barrett, 1986; Graham et al., 2002; Kelch and McClay, 2004). In Ethiopia, the species naturally occurring in the family Pontederiaceae is Eichhornia natans, which is recorded in fresh waters in Shewa and Illubabor (Getachew, 1997). Accordingly, in this test, two aquatic plants that share the same habitat but come from different families [Pistia stratiotes L. (Araceae) and Typha spp.] and crops selected based on their economic importance were tested. Based on relatedness, Commelina bengalensis, C. latifolia (Commelinaceae) and Lactuca sativa in the family Asteraceae were tested.

Eichhornia natans was evaluated, although, it is not prevalent in the Rift Valley of Ethiopia considering the level of relatedness to the target weed. The test crops selected based on their economic or ecological importance included cereals (wheat, barley, sorghum, tef and maize), vegetables (onion, garlic, pepper, cabbage, tomato, radish, carrot and cucumber); pulses (haricot bean, soy bean, lentil, chickpea, faba bean, field pea), oil crops (sesame, noug, safflower), a fiber crop (cotton), spices (fenugreek, cumin seeds and mustard), a sugar crop (sugarcane), stimulants (coffee), and weeds (broad-leaved cumbungi, water pennywort, and water lettuce).

In the first test, aquatic plants such as P. stratiotes and Typha spp. as well as the different crops selected for this study were evaluated. In the second test, the two species in the Pontederiaceae family were tested. All test plants were obtained from seedlings in the laboratory or by individual plants raised in the field. Plants or portion of plants were checked to eliminate extraneous insects or damage and placed individually in plastic Petri dishes with stem ends inserted into a hole in a water saturated filter disc. Two random and starved for $24 \mathrm{~h}$ were placed in a Petri dish. The leaf discs were randomly arranged in a circle. Two types of control were used: the first (CI), included only water hyacinth leaf discs, which provided the standard for optimal insect performance under the experiment conditions. In the second control (CII), no plants were provided. This provided a negative standard for insect survival in the absence of food. Both tests were arranged in a randomized block design with 10 replicates, each one consisting of one Petri dish as earlier described for each treatment and control. Finally, dishes were checked every 3-5 days for signs of feeding and oviposition and dead weevils were replaced with live ones. All plants before the end of the experiment were examined under the microscope for signs of feeding and oviposition.

\subsubsection{Oviposition tests}

Following the feeding and no-choice test result further oviposition tests (no-choice and two-choice oviposition tests) were done on E. natans and the target plant. These tests 
were conducted using a randomized complete block design with two treatments (nontarget test species and E. crassipes control) replicated three times. No-choice tests involved placing three pairs of the weevils on E. natans and on a separate E. crassipes control. Adults were removed after seven days and the plants were then monitored for larvae and pupae emergence. The test ended when all the larvae that emerged from the E. crassipes controls had developed to adulthood. Two-choice tests were conducted in the same way except that $E$. natans was paired with a single, similar-sized E. crassipes plant in a pot. Insects were released directly onto the adaxial surface of the leaves of $E$. natans.

\subsubsection{Weevil density-plant damage relationship}

Factorial experiments involving the two Neochetina weevils and four densities of herbivory treatments were conducted in randomized complete block design. Plants were grown for two weeks prior to the start of the study, after which all ramets, dead leaves, and stems were removed and the plants were weighed to know the wet weight. Adult Neochetina weevils were introduced into the experimental tubs at a density of one, two, and three pairs of weevils per plant (= two, four, and six weevils per pot). Two pots per replicate were used as controls. Preliminary assessment about the impact of one pair of the weevils per plant (as observed in the first phase experiment) indicated that the need to increase densities to get better reduction in growth and productivity of the plant (Y. Firehun 2014, personal observation). Adults were separated into male and female individuals at each density level so that each pot had both male and female adults. Oviposition occurred in all the treatments but all pupae were removed immediately to maintain the original herbivore densities, and any dead adult weevils were replaced with weevils of the same sex and, as a far as possible, of similar age. Plants were sampled weekly to record the number of leaves, number of ramets, number of defoliated petioles and average leaf area damage for whole plants on each $E$. crassipes rosette. The average leaf area damage per plant was scored from $1-6$ where $1=0 \%, 2=1-20 \% ; 3=21-40 \% ; 4=41-60 \% ; 5=61-80 \%$ and $6=81-100 \%$ of the leaf area damaged. New leaves and ramets were tagged and counted at each sampling interval to record the number of leaves and ramets produced during the study period. Each treatment was replicated three times and the duration of the trial was eight weeks, at which time all surviving plants were weighed.

\subsubsection{Statistical analysis}

Percentage data were transformed using arcsine transformation prior to analysis. All data were normally distributed therefore the means of the biomass data and the growth and reproductive parameters between the different herbivory treatments and the 


\section{Chapter 6}

controls were compared by one-way analysis of variance (ANOVA). Two way ANOVA were used to analyse the effect of insect density and their interaction on growth and reproductive parameters. Data were subjected to regression analyses to determine the relationship between insect biomass (as the independent variable) and the different measures of plant performance (as the dependent variables). All data were analysed using SAS (SAS, 2008).

\subsection{Results and discussion}

\subsubsection{Effect of single weevil density on the reproductive and growth potential of the weed}

Weevils treated basins showed a significant effect on the reproductive potential of the water hyacinth plant. The numbers of ramets, leaves per plant and inflorescences recorded on week eight were 1.62, 1.82 and 0.67 (Figure 6.1A, B, C), respectively, in water hyacinth plants treated with a combination of the two weevils, which were significantly lower $(\mathrm{P}<0.05)$ than in those treated with $N$. bruchi and $N$. eichhorniae alone. However, both weevil species restricted flowering and number of leaves per plant similarly when combined (Figure 6.1C). Neochetina bruchi significantly suppressed ramet development more than $N$. eichhorniae, when the two species were applied alone (Figure 6.1B). Center and Durden (1986) indicated that larvae of Neochetina weevils can disrupt fluid transport within the petiole and reduce the production of new leaves, or ramets, or both, because larvae tend to damage meristematic tissues. In this study, all life stages (eggs, larvae, as well as, pupae) both in single and combined treatments were observed (that is, indicating full larval cycle development). This ensures impact of the two weevils to ensue in an overlapping sequence as per their developmental stage. Thus, the significant suppressive effect on the reproductive plant parts by the two weevils could have resulted from weevil larvae (second/third instars) and the damage by the adults.

Percentage changes analysis in growth characteristics based on the initial means and final (eighth week) values indicated that other than none weevil treatment, all water hyacinth growth characteristics decreased as compared with the initial values (Table 6.1). The effect on the production of ramets, new leaves and biomass was highest (reduction above 30\%), demonstrating reduced reproductive capacity and vigour of the water hyacinth.

In this regard, reports indicated that the herbivory effect of the two weevil species reduced water hyacinth performance as deliberated by biomass production, clonal expansion and flowering; however, their combined effect remained similar to that of the use of either of the two species alone (Forno, 1981; Center et al., 1999a; Julien, 
2001; Ajuonu et al., 2003).

Therefore, significance of the present study is that combined release of the two weevils showed better reduction in the reproductive potential and vigour of the plant. This could be attributed to the co-existence of the two weevil species in water hyacinth plant and the complementary effects of the different growth stages of the respective weevil species (i.e., larvae and adult).

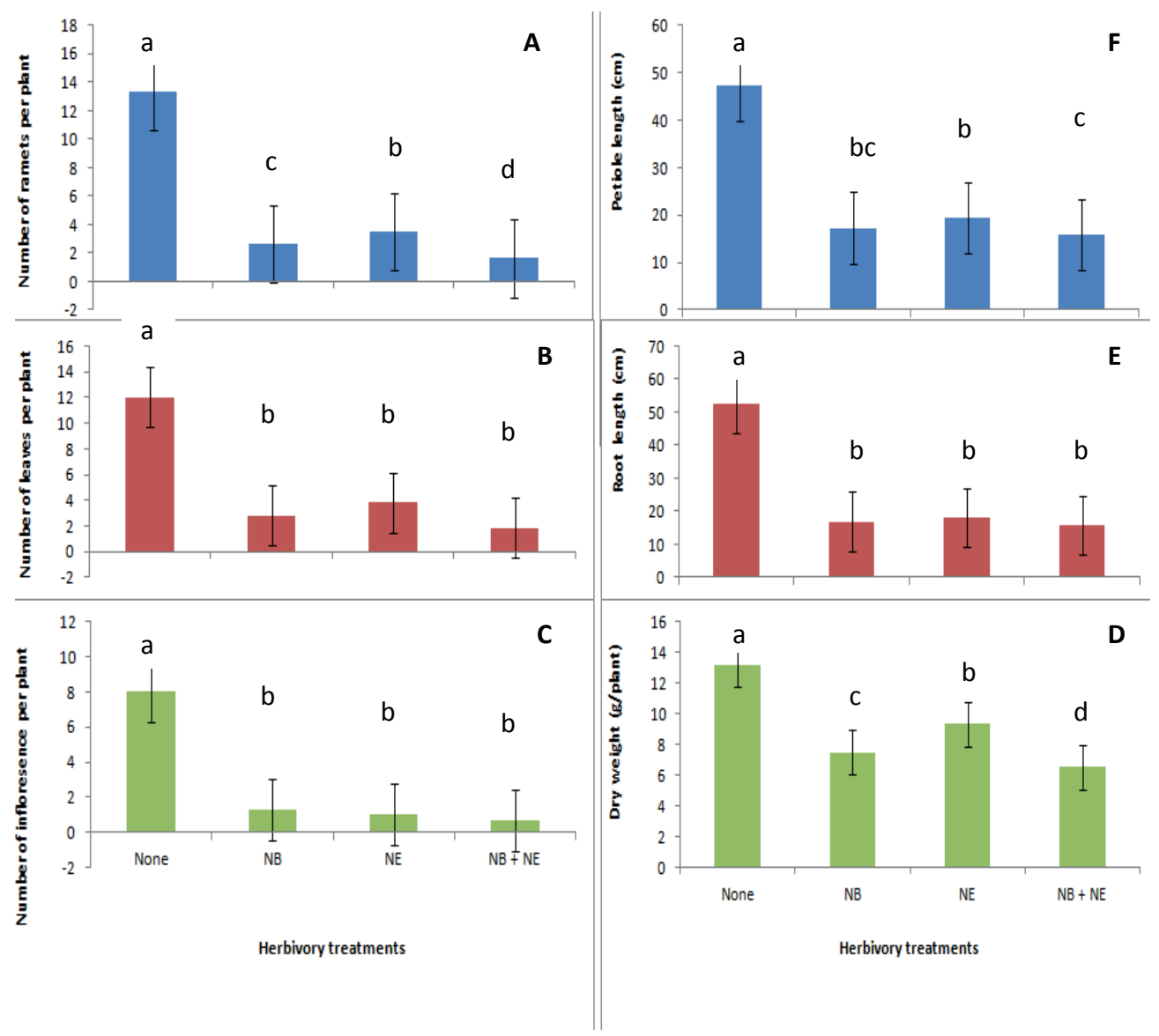

Figure 6.1. Impact of herbivory by Neochetina weevils on the mean number of ramets (A), number of leaves (B), number of inflorescences (C), dry weight (D), root length (E) and petiole length (F). Treatments are: None (no herbivory treatment), NB (applying only $N$. bruchi), NE (applying only N. eichhorniae) and NB+NE (applying both species). Means compared ANOVA; those with the same letter are not significantly different (Tukey's HSD, $\mathrm{P}<0.05)$. Error bars represent the standard error of the mean. 
Table 6.1. Percentage change $(+=$ increase; $-=$ decrease $)$ in mean values of water hyacinth growth characteristics eight weeks after introducing the two weevils.

\begin{tabular}{lccccc}
\hline & \multicolumn{2}{c}{ Number } & Length & \multicolumn{2}{c}{ Biomass } \\
\cline { 2 - 6 } Treatment & Ramets & Leaves & Petiole & Fresh & Dry \\
\hline None & +167 & +2 & +132 & +34 & +40 \\
NB & -34 & -52 & -15 & -37 & -20 \\
NE & -25 & -34 & -5 & -31 & -15 \\
NB + NE & -43 & -59 & -22 & -47 & -30 \\
\hline
\end{tabular}

None $=$ control without weevils, $\mathrm{NB}=N$. bruchi, $\mathrm{NE}=N$. eichhorniae, and $\mathrm{NB}+\mathrm{NE}=\mathrm{a}$ combination of both species at half the density of the single species treatments;

Percentage change $=\frac{\text { Final Measurement } @ W k 8-\text { Initial Measurement } @ W k 0}{\text { Initial Measurement } @ W k 0} * 100$

\subsubsection{Herbivory effect of the weevils at different densities on the reproductive potential of water hyacinth}

Among the different densities, three pairs of $N$. bruchi produced fewer ramets and leaves followed by two and one pairs (Table 6.2). Similarly, the number of ramets and leaves decreased as the density of $N$. eichhorniae increased. However, their effects were significantly different when released either alone or in combination and better suppression effects were achieved with combined application of the two weevils. Among the different combinations, the lowest number of ramets and leaves was recorded for three pairs of $N$. bruchi released in combination with two pairs of $N$. eichhorniae, which was followed by three pairs of $N$. eichhorniae combined with two as well as, three pairs of $N$. bruchi. However, no difference was observed on number of ramets and leaves between combined application of three pairs of $N$. bruchi with two and three pairs of $N$. eichhorniae. Leaf number and ramet production are among the critical growth factors that limit water hyacinth survival (Center and Van, 1989; Heard and Winterton, 2000; Coetzee et al., 2007). Water hyacinth density and its spreading capacity is mainly associated with the reproductive mechanism (i.e, asexual reproduction), therefore, a reduction in reproduction would reduce expansion of water hyacinth mats and its invasive potential (Byrne et al., 2010). The herbivory effect of combined application of the two weevil species on number of leaves and ramets would also affect the plant photosynthetic capacity and its buoyancy capability. Hence, this combined herbivory effect of the two weevils would reduce the expansion rate of the weed. Similarly, a correlation analysis showed a weak but significant negative correlation between insect biomass and ramet as well as, leaf production $(\mathrm{r}=-0.50$; $\mathrm{P}<0.0001$ and $\mathrm{r}=-0.54 ; \mathrm{P}<0.0001)$. This indicated that high densities of the 
Neochetina weevils reduced invasive potential of the weed by suppressing the expansion of its mats.

Table 6.2. Effects of different densities of N. bruchi (NB) and N. eichhorniae (NE) on mean values of water hyacinth growth and reproductive characteristics at eight weeks after introduction.

\begin{tabular}{|c|c|c|c|c|c|c|c|}
\hline NB & $\mathbf{N E}$ & $\begin{array}{c}\text { No. } \\
\text { Ramets } \\
\text { (no) }\end{array}$ & $\begin{array}{c}\text { No. } \\
\text { Leaves } \\
\text { (no) }\end{array}$ & $\begin{array}{c}\text { Damaged } \\
\text { Leaf } \\
\text { Area } \\
\text { (scale) } \\
\end{array}$ & $\begin{array}{l}\text { Petiole } \\
\text { length } \\
(\mathrm{cm})\end{array}$ & $\begin{array}{c}\text { Defoliated } \\
\text { petiole }\end{array}$ & $\begin{array}{c}\text { Weight } \\
\text { (g) }\end{array}$ \\
\hline \multirow[t]{4}{*}{ NBO } & NE0 & 4.73 & 8.27 & 0.00 & 37.17 & 0.00 & 354.00 \\
\hline & NE1 & 1.73 & 6.23 & 3.93 & 21.39 & 1.40 & 153.33 \\
\hline & NE2 & 1.53 & 3.27 & 4.40 & 20.99 & 1.53 & 116.07 \\
\hline & NE3 & 1.00 & 3.00 & 4.93 & 20.49 & 1.86 & 99.83 \\
\hline \multirow[t]{4}{*}{ NB1 } & NE0 & 2.03 & 6.41 & 3.93 & 22.34 & 0.86 & 169.63 \\
\hline & NE1 & 1.53 & 5.43 & 3.97 & 21.77 & 1.40 & 126.50 \\
\hline & NE2 & 0.97 & 2.80 & 4.13 & 20.02 & 1.70 & 103.65 \\
\hline & NE3 & 0.97 & 1.63 & 4.93 & 18.51 & 1.87 & 93.32 \\
\hline \multirow[t]{4}{*}{ NB2 } & NE0 & 1.56 & 4.90 & 4.20 & 20.95 & 1.43 & 122.63 \\
\hline & NE1 & 1.43 & 4.00 & 3.93 & 20.08 & 1.93 & 110.26 \\
\hline & NE2 & 1.03 & 2.46 & 4.93 & 18.65 & 1.90 & 89.74 \\
\hline & NE3 & 0.74 & 0.70 & 5.67 & 16.27 & 2.65 & 68.33 \\
\hline \multirow[t]{4}{*}{ NB3 } & NE0 & 1.5 & 4.20 & 4.40 & 20.35 & 1.63 & 109.16 \\
\hline & NE1 & 1.5 & 3.45 & 5.30 & 19.34 & 1.87 & 98.57 \\
\hline & NE2 & 0.50 & 0.40 & 5.93 & 15.07 & 2.80 & 66.49 \\
\hline & NE3 & 0.44 & 0.40 & 5.90 & 14.49 & 2.80 & 64.37 \\
\hline \multicolumn{2}{|c|}{ LSD (0.05) NB*NE } & 0.24 & 0.43 & 0.27 & 0.86 & 0.11 & 4.10 \\
\hline \multicolumn{2}{|c|}{ Correlation (r) } & -0.50 & -0.54 & 0.57 & -0.57 & 0.62 & -0.54 \\
\hline \multicolumn{2}{|c|}{ Regression $\left(\mathbf{R}^{2}\right)$} & 0.64 & 0.89 & 0.70 & 0.66 & 0.87 & 0.84 \\
\hline \multicolumn{8}{|c|}{ Significance $(P)$ alone $\&$ interactions ${ }^{1}$} \\
\hline \multicolumn{2}{|l|}{ NB } & $* *$ & $* *$ & $* *$ & $* *$ & $* *$ & $* *$ \\
\hline \multicolumn{2}{|l|}{ NE } & $* *$ & $* *$ & $* *$ & $* *$ & $* *$ & $* *$ \\
\hline \multicolumn{2}{|c|}{$\mathbf{N B} * \mathbf{N E}$} & $* *$ & $* *$ & $* *$ & $* *$ & $* *$ & $* *$ \\
\hline
\end{tabular}

$1 * *$ indicates significance at $\mathrm{P}<0.01$ 


\subsubsection{Herbivory effect of the weevils at different densities on the growth of water hyacinth}

The mean length of petiole was highly significantly $(\mathrm{P}<0.01)$ affected by the density of the two weevil species and their interaction (Table 6.2). The mean length of petiole decreased with an increase in density of the two weevils, which shows considerable impact that all densities of the two weevils had on growth rates of water hyacinth. However, the rate of decrease by the different densities was not similar. Among the different combinations, the lowest mean petiole length was recorded in basins that received three pairs of the two weevil species followed by two by two and three by two combinations of $N$. bruchi and $N$. eichhorniae. At the end of the trial, all densities of the two weevils and the length of the petiole were linearly related and their regression explained about $66 \%$ of the variation $\left(\mathrm{R}^{2}=0.66 ; \mathrm{P}<0.0001\right)$; whilst, a significant negative correlation $(\mathrm{r}=-0.57 ; \mathrm{P}<0.0001)$ was found between the length of the petiole and insect biomass.

The mean number of defoliated petioles increased proportionally with the extent of damage caused by the weevil herbivory. On average, about three petioles per plant were defoliated by three pairs, two by two and three by two combinations of $N$. bruchi and $N$. eichhorniae at the end of the trial. Similarly, nearly all leaf area was damaged by three pairs, two by two and three by two combinations of $N$. bruchi and $N$. eichhorniae. However, no significant difference was observed among these combinations as compared with the other treatments. A significant positive correlation ( $\mathrm{r}=0.62 ; \mathrm{P}<0.0001$ for defoliated petiole and $\mathrm{r}=0.57 ; \mathrm{P}<0.0001$ for overall leaf area damage) was exhibited by the two insect biomass at the end of the trial. Number of defoliated petioles as well as, overall leaf area damage was linearly related with the different densities of the two weevils and explained about 87 and $70 \%$ of the variation, respectively. Weevil herbivory resulted in decreased leaf and petiole length, increased leaf mortality and overall reduction in plant biomass (Center, 1985; Center and Van, 1989). The principal impact of weevil herbivory lies in the disruption of water hyacinth leaf dynamics, resulting in death of the plant when leaf mortality exceeds leaf production (Center et al., 2005). This indicated that the herbivory potential of the two weevils varies depending on density of the weevils, which is in agreement with the study of Wright and Center (1984) who reported that water hyacinth weevil density relates to leaf damage.

\subsubsection{Herbivory effect of the weevils at different densities on the biomass of water hyacinth}

Plant biomass (fresh weight) was highly significantly $(\mathrm{P}<0.01)$ affected by different densities of the two weevils and their interaction at eight weeks after release of the 
herbivory treatments (Table 6.2). The three pairs of $N$. bruchi gave the lowest plant weight when combined with two or three pairs of $N$. eichhorniae indicating that it has a significant suppressive effect on plant weight. In agreement with this finding, Center et al. (2005) reported that herbivory by $N$. eichhorniae and N. bruchi decreased water hyacinth's competitive performance by $98 \%$ at a density of four weevils per plant. The relationship between final biomass of water hyacinth plants at week eight as a function of increasing levels of herbivory was curvilinear (Figure 6.2). The observed convex relationship between weevil density and water hyacinth biomass reduction could be well-described by a negative $\log$ function $\left(\mathrm{R}^{2}=0.98\right)$. Water hyacinth ability to compensate for herbivory was a linear or curvilinear function of insect density, which is a relationship commonly observed between plants and phytophagous insects (Meyer, 1998; Schooler and McEvoy, 2006; Stanley et al., 2007). Overall, the results indicated that herbivory loads greater than one weevil plant ${ }^{-1}$ were enough to trigger significant biomass reductions with a maximum being recorded at density of six weevils plant ${ }^{-1}$. In their adaptability study, Firehun et al. (2015) indicated that more than six weevils plant ${ }^{-1}$ was recorded for both species. Thus, assessment of the optimum densities of the two weevils for release in the Rift Valley of Ethiopia confirms the two weevil's ability to reduce fitness of water hyacinth plant.

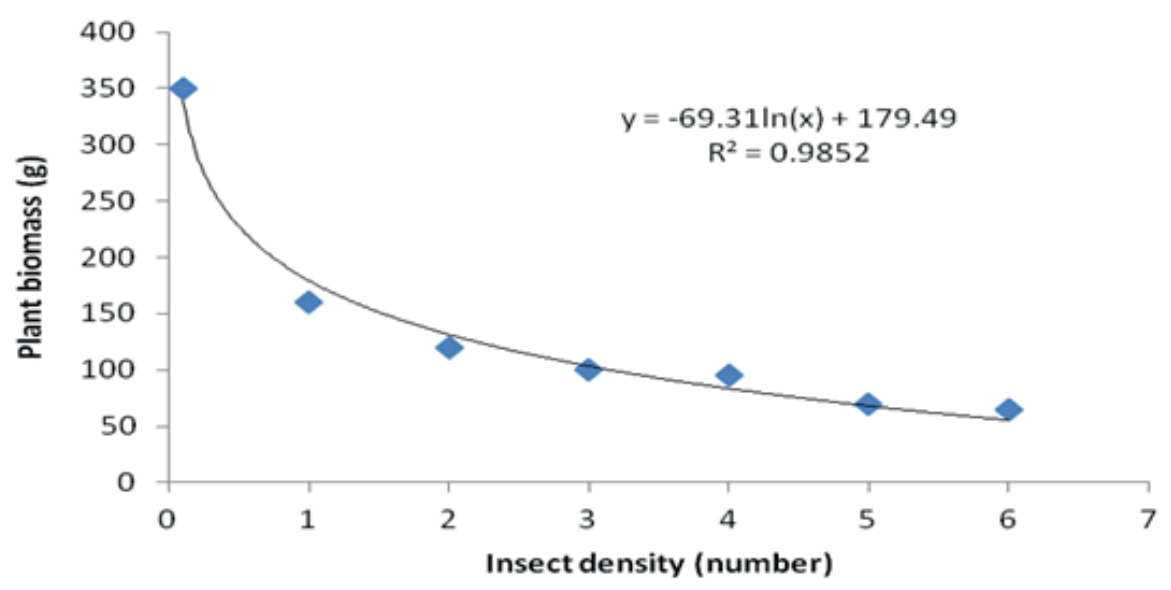

Figure 6.2. Regression of different densities of N. bruchi (NB) and N. eichhorniae (NE) (\#) and final weight $(\mathrm{g})$ of water hyacinth plants at the end of the eight week study period. 


\subsubsection{Host specificity of Neochetina weevils}

Table 6.3 shows the extent of feeding and oviposition of adults of the two Neochetina weevils on each test plant species. The non-choice test indicated that the two weevils can only feed on E. crassipes and E. natans (Pontederiaceae); P. stratiotes (Araceae) and $B$. oleracea (Brassicaceae). However, the extent of feeding scars observed in these plants was very little while extensive feeding was recorded on $E$. crassipes.

All the insects died within few days in test enclosures with water but no plants. Unlike the other test plant, $N$. eichhorniae and $N$. bruchi showed a high level of oviposition and developmental fidelity to E. crassipes. In agreement with this finding, Center et al. (2002) reported that the two Neochetina weevils were specific to water hyacinth plan despite being released in different countries. The host range assessment study revealed that $N$. eichhorniae and $N$. bruchi were restricted to the aquatic plant water hyacinth, Pontederiaceae. Even families very closely related to Pontederiaceae, namely; Asteraceae and Commelinaceae, were not suitable for survival or development. No adult survival and feeding over were recorded on nonPontederiaceae plants and no progeny was produced on E. natans (Pontederiaceae), $P$. stratiotes (Araceae) and B. oleracea (Brassicaceae), providing evidence that they are not suitable hosts. For all the test plant species, the no-choice trials were, in effect, starvation studies because none of the introduced adults survived a week.

The adults were removed from the water hyacinth plants so that comparisons could be made between the numbers of progenies produced on each species over an equal period. Within the Pontederiaceae, only E. crassipes exhibited extensive feeding and was found to be suitable for the complete development of the insect. The pupation behaviour of these insects, whereby they make a pupal cocoon in the roots of floating water hyacinth, makes it highly unlikely that any substrate rooted plant could provide a suitable host (Julien et al., 1999; Center et al., 2002).

\subsection{Conclusion}

Based on the analyses of data on number of ramets and leaves, defoliated petiole, overall leaf area damage, and plant weight, combined application of $N$. eichhorniae and $N$. bruchi showed highly significant herbivory effect on water hyacinth. The observed relationship between weevil's density and plant performance indicated that $N$. eichhorniae and $N$. bruchi are promising biological control agents for E. crassipes. It was confirmed from these data that $N$. eichhorniae and $N$. bruchi are sufficiently host specific and therefore, can be safely released in the Rift Valley of Ethiopia for the management of water hyacinth. 
Table 6.3. Results of feeding and no-choice oviposition tests for $N$. eichhorniae and $N$. bruchi.

\begin{tabular}{|c|c|c|c|c|}
\hline Family & Genus \& Species & Common Name & Feeding & Oviposition \\
\hline \multirow[t]{2}{*}{ Apiaceae } & Daucus carota L. & Carrot & - & - \\
\hline & Hydrocotyle verticillata L. & Water pennywort & - & - \\
\hline Araceae & Pistia stratiotes L. & Water lettuce & ++ & - \\
\hline \multirow[t]{2}{*}{ Asteraceae } & Guizotia abyssinica & Noug & - & - \\
\hline & Lactuca sativa & Lettuce & ++ & - \\
\hline \multirow[t]{2}{*}{ Brassicaceae } & Raphanus sativus L. & Radish & - & - \\
\hline & Brassica oleracea capitata $\mathrm{L}$. & Cabbage & ++ & - \\
\hline Chenopodiaceae & Ipomea batata (L.) Lam. & Sweet potato & - & - \\
\hline Cyperaceae & Cyperus papyrus L. & Papyrus & - & - \\
\hline Compositae & Carthamus tinctorius L. & safflower & - & - \\
\hline \multirow[t]{2}{*}{ Commelinaceae } & Commelina bengalensis, & & ++ & - \\
\hline & C. latifolia A. & & ++ & - \\
\hline Cruciferae & Brassica carinata Cobs. & Mustard & - & - \\
\hline Cucurbitaceae & Cucumis sativus L. & Cucumber & - & - \\
\hline \multirow[t]{7}{*}{ Fabaceae } & Phaseolus vulgaris L. & Haricot bean & - & - \\
\hline & Glycin $\max (\mathrm{L})$ Merr. & Soy bean & - & - \\
\hline & Cicer arietinum $\mathrm{L}$. & Chickpea & - & - \\
\hline & Vicia faba L. & Faba bean & - & - \\
\hline & Pisum sativum L. & Pea & - & - \\
\hline & Lens culinaris Medik & Lentil & - & - \\
\hline & Trigonella foenum-graecum & Fenugreek & - & - \\
\hline \multirow[t]{2}{*}{ Lileaceae } & Allium sativum L. & Garlic & - & - \\
\hline & Allium cepa $\mathrm{L}$. & Onion & - & - \\
\hline Malvaceae & Gossypium hirsutum L. & Cotton & - & - \\
\hline Pedaliaceae & Sesamum indicum $\mathrm{L}$. & Sesame & - & - \\
\hline \multirow[t]{6}{*}{ Poaceae } & Hordeum vulgare $\mathrm{L}$. & Barley & - & - \\
\hline & Sorghum bicolar (L.) Moench & Sorghum & - & - \\
\hline & Zea mays L. & Maize & - & - \\
\hline & Eragrostis tef (Zuccagni) Trotter & Teff & - & - \\
\hline & Saccharum officinarum $\mathrm{L}$. & Sugarcane & - & - \\
\hline & Triticum aestivum $\mathrm{L}$. & Wheat & - & - \\
\hline Rubiaceae & Coffee arabica $\mathrm{L}$. & Coffee & - & - \\
\hline \multirow[t]{2}{*}{ Pontederiaceae } & Eichhornia crassipes (Mart.) Solms & Water hyacinth & ++++ & ++++ \\
\hline & Eichhornia natans & & ++ & - \\
\hline \multirow[t]{3}{*}{ Solanaceae } & Lycopersicon esculentum Mill. & Tomato & - & - \\
\hline & Capsicum pepper & Pepper & - & - \\
\hline & Solanum tuberosum L. & Potato & - & - \\
\hline Typhaceae & Typha orientalis & Roscoe & - & - \\
\hline Umbelliferae & Cuminum cyminum & Cumin seed & - & - \\
\hline Blank Control & Water but no plant & & - & - \\
\hline
\end{tabular}


Chapter 6

\section{Acknowledgements}

We acknowledge EIAR-UNEP-GEF and Ethiopian Sugar Corporation for funding this research work. We are grateful to Namuloge Agricultural and Animal Production Research Institute based in the Republic of Uganda, for the support during importation of the weevils. We also acknowledge Mr Ambachew Dametie, Mr Abiy Negese, $\mathrm{Mr}$ Yohannes Zekarias for the technical support. 


\section{CHAPTER 7}

\section{Integrated control of water hyacinth with a fungal pathogen (Alternaria alternata [Fr.] Keissler) and Neochetina weevils in the Rift Valley of Ethiopia}

Y. Firehun, P.C. Struik, E.A. Lantinga and T. Taye (2017)

Submitted to Biocontrol Science and Technology 


\begin{abstract}
A study was conducted for two years to evaluate the integrated use of Neochetina eichhorniae and N. bruchi, host-specific herbivorous weevil species, and an indigenous plant pathogen (Alternaria alternata) for controlling water hyacinth in the Rift Valley of Ethiopia. Water hyacinth plants were exposed to one of eight treatments: control (no weevils, no foliar fungal application); only weevils with one weevil species ( $N$. eichhorniae alone, no A. alternata or $N$. bruchi alone, no $A$. alternata); only weevils with two weevil species (only $N$. eichhorniae $+N$. bruchi, no foliar A. alternata); only fungal spray (no weevils, foliar application of A. alternata); combination of weevils and fungal spray ( $N$. bruchi alone + foliar fungal application, $N$. eichhorniae alone + foliar fungal application or $N$. bruchi $+N$. eichhorniae + foliar fungal application). Water hyacinth plants that received the two weevils combined with $A$. alternata showed a disease index (DI) of $90 \%$ compared with DI values of $70 \%$ and $60 \%$ recorded in $N$. bruchi combined with A. alternata or $N$. eichhorniae combined with A. alternata, respectively. Application of both weevils combined with A. alternate showed about $97 \%$ and $8 \%$ reduction in number of new ramets and fresh weight, respectively. Thus, it is concluded that application of the three agents together had an overall syngergistic effect on water hyacinth control.
\end{abstract}

Keywords: Alternaria alternata, aquatic weeds, biological control, Neochetina bruchi, Neochetina eichhorniae, water hyacinth 


\subsection{Introduction}

Water hyacinth, Eichhornia crassipes (Mart.) Solms (Pontederiaceae), is renowned as the world's most noxious aquatic weed that causes environmental, economic, and social difficulty in the tropics and the sub-tropics (Holm et al., 1977). In the Rift Valley of Ethiopia, this floating plant forms impenetrable mats across waterways and stagnant water bodies such as lakes, dams, reservoirs, irrigation canals and drainage structures. These mats result in blockage of irrigation canals, and meddling with hydro-electric power generation, sugarcane and vegetable production (Firehun et al., 2013). However, management of water hyacinths by manual, mechanical, and chemical methods is costly and unending (Center et al., 1999a).

In 2011, efforts to control water hyacinth using weevils were made in Ethiopia. The host-specific weevils Neochetina eichhorniae Warner and N. bruchi Hustache have been used already for a long time as biological agents for control of water hyacinth in different parts of the world (Harley, 1990). In Ethiopia, N. eichhorniae and N. bruchi were introduced from the Biological Control Unit, Namuloge Agricultural and Animal Production Research Institute, based in the Republic of Uganda. Adaptability, hostspecificity (ecological as well as economic plant species of Ethiopia) and pre-release impact assessment studies confirmed their suitability for release in the Rift Valley of Ethiopia (Firehun et al., 2015, 2016). Insects alone have generally not caused the necessary damage level (Perkins, 1978; Center et al., 1982; Martinez et al., 2001). However, it is known that their effects are heightened when they are applied in combination with plant pathogens (Martinez and Gomez, 2007). Several fungal pathogens have been reported to attack water hyacinth in various parts of the world. Various strains in the genera, Acremonium, Alternaria, Cercospora, and Myrothecium have been studied intensively as biocontrol agents and shown to be effective under experimental conditions (Shabana et al., 1995a, b, 1997, 2000; Charudattan, 2001b; Martinez and Gutierrez, 2001; Mohan et al., 2003; Praveena and Naseema, 2004).

A survey of fungal pathogens was made in the Rift Valley of Ethiopia (Firehun et al., 2017) with the aim of identifying at least one indigenous fungus with prospect for development as a mycoherbicide to boost the effects of the insect biological control agents. Alternaria alternata (Fr.) Keissler was selected as one of the fungi with the largest potential. Alternaria alternata has been described as a pathogen of water hyacinth in Australia (Galbraith, 1987), Egypt (El-Morsy, 2004; Elwakil et al., 1990; Shabana et al., 1995b), Bangladesh (Bardur-ud-Din, 1978), India (Aneja and Singh, 1989) and Ethiopia (Firehun et al., 2017). Mohan et al. (2003) highlighted the potential to use A. alternata as biological control agent of water hyacinth without negative effects on plants of economic and ecological importance. 


\section{Chapter 7}

Many biological control projects involve the release of multiple agents exerting cumulative impacts (Syrett et al., 2000; Denoth et al., 2002). Associations among weed biological control agents may arise directly or indirectly. The direct association arises, if influx by one agent directly alters the ability of others to pervade the target (Caesar, 2003). The indirect association arises, if attack alters target plant quality, indirectly influencing the feeding, survival and/or reproduction of other agent(s) (Milbrath and Nechols, 2004). Positive interactions between insect herbivores and plant pathogenic fungi are potentially useful in biological water hyacinth control. The few attempts made so far to utilize this potential for the management of water hyacinth demonstrated the feasibility and commercial potential of augmenting weevils with pathogens (Moran and Graham, 2005; Martinez and Gomez, 2007). The weevils' feeding wounds facilitate entry of fungal pathogens, and weevils can also deliver fungal inoculum directly onto cuticular surfaces. Therefore, the current study was initiated to evaluate the integrated use of $N$. eichhorniae and $N$. bruchi, host-specific herbivorous weevil species, and an indigenous plant pathogen (A. alternata) for controlling water hyacinth in the Rift Valley of Ethiopia.

\subsection{Materials and methods}

\subsubsection{Insects, plants and pathogen}

Water hyacinth weevils were collected from a mass rearing site at Wonji Research Station, located in the Rift Valley of Ethiopia ( $8^{\circ} 31^{\prime} \mathrm{N} ; 39^{\circ} 20^{\prime} \mathrm{E} ; 1540 \mathrm{~m}$ a.s.1.). Water hyacinth plants were grown in untreated irrigation water supplemented with 2.5 ppm nitrogen and potassium, $9.5 \mathrm{ppm}$ phosphorous, and $2 \mathrm{ppm}$ iron. Blue dye $(0.01 \%$ $\mathrm{v} / \mathrm{v}$ ) was added to the growth medium to inhibit algal growth. The plants were acclimatized to the growing condition for a month.

Indigenous strain of the fungal pathogen A. alternata (Wonji-WH-4) was isolated from surface-sterilized leaf disks $(0.5 \mathrm{~cm})$ cut from experimentally infected leaves collected at Wonji Research Station sites. Disks and colony transfers were cultured on solid potato dextrose agar $\left(39 \mathrm{~g} \mathrm{l}^{-1}\right)$ containing $5 \mathrm{~g} \mathrm{l}^{-1}$ yeast extract (Difco, Detroit, Michigan). Two-week-old sporulating cultures were used for inoculations. Spores were harvested by flooding the plates with distilled water and lightly scraping the surface. The resulting spores were suspended in a formulation, and the concentration was adjusted to $1 \times 10^{6}$ spores $\mathrm{ml}^{-1}$. The formulations consisted of $3 \mathrm{ml}$ corn oil, $15 \mathrm{ml}$ of an emulsifier (Tween 80) and $500 \mathrm{ml}$ water.

Water hyacinth weevils were collected from infested water hyacinth plants. An insect colony was established with 200 weevils (1:1 male:female), which were placed into a 601 tented tank containing water hyacinth shoots. Weevils needed for the 
experimental studies were obtained from this colony.

\subsubsection{Treatments and experimental design}

The experiment was performed five times in a randomized complete block design with three replications. The water hyacinth plants were maintained in $30 \mathrm{~L}$ tanks in the lath house ( $\mathrm{n}=8$ plants per treatment) for about two months during each experimental period. The weevils were sorted by both sex and species following the procedure developed by CSIRO scientists in Australia (Julien et al., 1999), and subsequently released onto plants at a density of one weevil per plant. The experiment consisted of the following eight treatments, each containing eight plants: control (no weevils, no foliar fungal application); only weevils with one weevil species (only N. eichhorniae, no A. alternata or only $N$. bruchi, no A. alternata); only weevils with two weevil species (only $N$. eichhorniae $+N$. bruchi, no foliar A. alternata); only fungal spray (no weevils, foliar application of $A$. alternata); and combination of weevils and fungal spray ( $N$. bruchi alone + foliar fungal application, $N$. eichhorniae alone + foliar fungal application or $N$. bruchi $+N$. eichhorniae + foliar fungal application).

\subsubsection{Application of agents}

Forty-eight weevils ( 1 male : 1 female) per replication were added onto plants selected for exposure to the weevils alone and to both the weevils and the A. alternata fungus. In order to prevent $N$. eichhorniae and $N$. bruchi ovipositing on the non-treated plants, all treatments were placed in separate cages. The cages were covered with fine white netting.

Two weeks after the commencement of each experiment (release of the weevil), a suspension of spores having a formulation of about $1 \times 10^{6}$ spores $\mathrm{ml}^{-1}$ was sprayed until run-off by using a hand-held airbrush sprayer onto the foliage of plants selected for exposure to either the A. alternata fungus alone or to both the A. alternata fungus and the weevils. The control plants were sprayed with sterile distilled water containing Tween 80. Each plant was then covered overnight with a moistened clear plastic bag to provide optimal conditions for fungal infection in the treatments with application of $A$. alternata. To restrict the spread of the pathogen among the treatments, plants in the non-pathogen treatments were sprayed with the broad-spectrum fungicide TILT ${ }^{\circledR}$ at a rate of $5 \mathrm{ml}$ each time. Plants that were artificially inoculated with the pathogens were sprayed with the same volume of water.

\subsubsection{Data collection and analysis}

Disease intensity and severity were rated by visual observations during a total period of 30 days. Disease intensity was evaluated visually on the basis of initiation of 


\section{Chapter 7}

disease and increase in disease area every day after application of the inocula, using a score chart framed by Freeman and Charudattan (1984) that rated disease intensity as excellent $(+++)$, good $(++)$, poor $(+)$, and no infection $(-)$ after 5, 10, 15, 20, 25 and 30 days. Disease was scored using a 0 to 5 scale rating system where $0=$ no symptoms; $1=1-10 \% ; 2=11-25 \% ; 3=26-50 \% ; 4=51-75 \%$, and $5=\geq 75 \%$ area covered by spots on leaves, until 30 days after fungal inoculation. All the ratings from each experiment were then averaged and a disease index (DI) was calculated according to Chaube and Singh (1991):

$$
\text { Disease Index }(\mathrm{DI})=\frac{\text { Sum of all ratings } * 100}{\text { Total number of leaves measured } * \text { Maximum disease index }}
$$

where, the sum of all numerical ratings is $(0 \times \mathrm{N} 0)+(1 \times \mathrm{N} 1)+(2 \times \mathrm{N} 2)+(3 \times \mathrm{N} 3)+$ $(4 \times \mathrm{N} 4)+(5 \times \mathrm{N} 5)$; with N0, number of leaves with score 0 ; N1, number of leaves with score 1 ; and .... N5, number of leaves with score 5 .

Leaf scarring by the weevils was monitored weekly. Two month after the start of the treatments (i.e., 6 weeks after inoculation), total numbers of shoots (rosettes) and flowers were counted in each tank, and leaf counts, petiole length, root and shoot fresh weight as well as asexual plant production via axillary buds were assessed on a subset of five plants per tank. The effects of treatments were analysed using Analysis of Variance (ANOVA) (SAS, 2008). The percentage data recorded for evaluating disease index of different fungi were transformed first with arcsine transformation prior to being compared using one-way analysis of variance. The treatment means were compared with Fisher's honest least significant difference (LSD) at 5\% level of significance.

\subsection{Results and discussion}

\subsubsection{Effect on disease development and feeding scars}

Water hyacinth leaves in the four treatments inoculated with either only A. alternata or A. alternata in combination with the weevils developed disease symptoms within 4-7 days after inoculation. The disease development results indicated that there was a significant difference $(\mathrm{P}<0.05)$ among the four treatments with fungus application when introduced alone or in combination with weevils. Among the treatments, 10 days after inoculation, the maximum disease rating was recorded in water hyacinth plants that received the two weevil species $(\mathrm{NB}+\mathrm{NE})$ combined with $A$. alternata $(\mathrm{DI}=29 \%$, $\mathrm{P}<0.05$ ) followed by water hyacinth plants that received $N$. bruchi combined with $A$. alternata $(\mathrm{DI}=22 \%)$ and $N$. eichhorniae combined with A. alternata $(\mathrm{DI}=17 \%)$. As 
the number of days after inoculation increased, the disease score also increased (Figure 7.1). Twenty days after inoculation, the combined application of the two weevil species augmented with $A$. alternata showed a DI of $70 \%(\mathrm{P}<0.001)$, which was much higher than that of the treatment with only A. alternata (DI $=19 \%$ ). Thirty days after inoculation, water hyacinth plants that received $A$. alternata combined with the two weevils showed a DI of $90 \%$ whereas DI levels of $70 \%$ and $60 \%$ were recorded in A. alternata combined with $N$. bruchi and $N$. eichhorniae, respectively.

These findings confirmed that $A$. alternata can heavily infect water hyacinth (ElMorsy, 2004; Ray, 2006). However, the spread of A. alternata on more mature plants was slower and limited to the lower leaves and the stem. Similarly, Charudattan (2005) reported that on plants that have the ability to regenerate quickly, spread of pathogens was limited to lower leaves.

Analysis of results on weevil feeding scars indicated that there was a significant difference $(\mathrm{P}<0.05)$ among the weevil treatments when introduced alone or combined. Adult feeding by both species removed large areas of the laminal cuticle. Among the weevil treatments, the maximum number of feeding scars per plant was recorded in water hyacinth plants that received the combination of the two weevils $(220 \pm 14, \mathrm{P}<0.05)$ followed by water hyacinth plant that received $N$. bruchi $(190 \pm$ $10)$ or $N$. eichhorniae $(140 \pm 15)$ alone. Average plant disease damage levels were

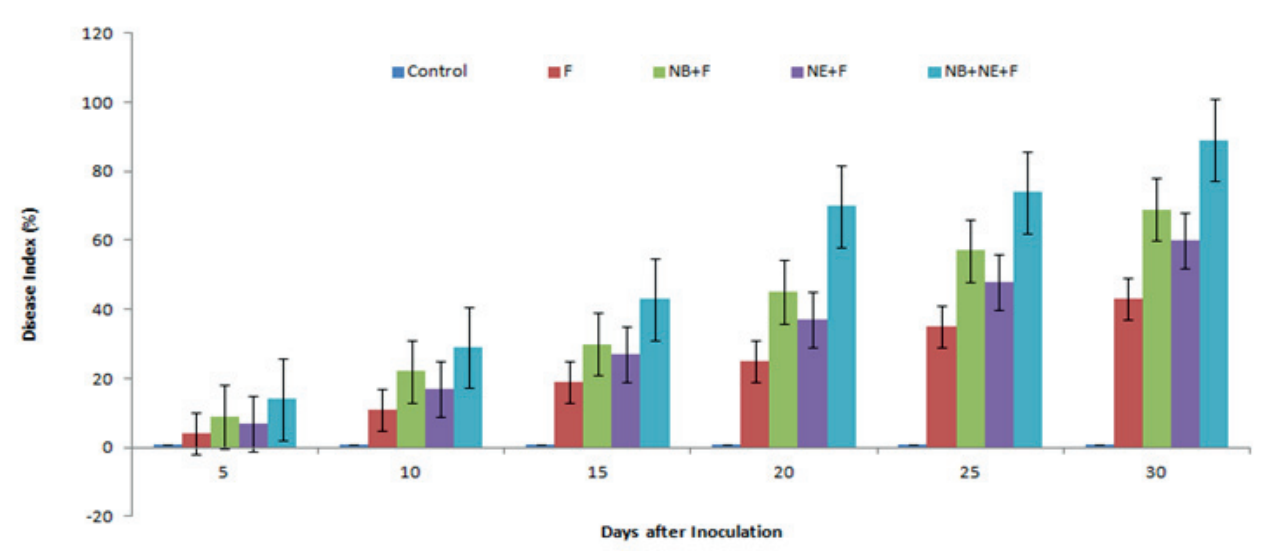

Figure 7.1. Impact of herbivory by Neochetina weevils augmented with the fungal pathogen A. alternata on disease index. Treatments: C (control treatment), F (applying only Alternaria alternata), NB+F (N. bruchi alone augmented with A. alternata), NE+F (N. eichhorniae alone augmented with $A$. alternata and $\mathrm{NB}+\mathrm{NE}+\mathrm{F}$ (both weevil species augmented with $A$. alternata). Error bars represent the standard error of the mean. 
significantly higher in plants that received application of $A$. alternata augmented with the two weevil species (mean $\pm \mathrm{SE} ; 0.89 \pm 0.009$ ). Plants where A. alternata was augmented with $N$. bruchi $(0.75 \pm 0.01)$ and plants where $A$. alternata was augmented with $N$. eichhorniae $(0.71 \pm 0.01)$ exhibited higher disease damage than plants that received only $A$. alternata $(0.65 \pm 0.01)$.

Twenty days after weevil infestation, necrosis development was 2.8 and 1.6 fold greater in plants that received $A$. alternata augmented with both weevils and $A$. alternata combined with weevils alone, respectively, than in plants receiving only $A$. alternata. Thirty days after weevil infestation, the percentage of leaf area covered by lesions increased by 2.2 fold in plants augmented with weevils. A correlation analysis showed a strong and significant positive correlation between number of feeding scars and DI ( $\mathrm{r}=0.93$; $\mathrm{P}<0.0001$; Table 7.1). This indicates that the higher number feeding scars due to the Neochetina weevils enabled a better disease development.

Galbraith (1987) reported that feeding by $N$. eichhorniae increased infection by Acremonium zonatum. In the present study the disease symptoms on water hyacinth caused by the fungus were more severe on weevil-damaged leaves. In various earlier studies (Charudattan et al., 1978; Galbraith, 1987; Moran, 2005; Martínez and Gómez, 2007), the disease causing efficiency of A. zonatum and Cercospora piaropi was considerably enhanced when the pathogens were applied to water hyacinth in the presence of Neochetina weevils. The feeding by the weevils gave access for the fungal

Table 7.1. Effects of augumented application of Neochetina weevils with fungal pathogen $A$. alternata.

\begin{tabular}{lccccc}
\hline Treatments & Fscar & $\begin{array}{c}\text { Disease } \\
\text { index } \\
(\%)\end{array}$ & $\begin{array}{c}\text { Plant } \\
\text { damage } \\
(\mathbf{\%})\end{array}$ & $\begin{array}{c}\text { Increase in } \\
\text { necrosis } \\
(@ 20 D A I)\end{array}$ & $\begin{array}{c}\text { Increase in } \\
\text { necrosis } \\
\text { (@30DAI) }\end{array}$ \\
\hline $\mathrm{C}$ & 0 & 0 & 0 & 0 & 0 \\
$\mathrm{~F}$ & 0 & 40 & 65 & 1 & 1 \\
$\mathrm{NB}+\mathrm{F}$ & 190 & 69 & 75 & 1.8 & 1.7 \\
$\mathrm{NE}+\mathrm{F}$ & 140 & 60 & 71 & 1.5 & 1.4 \\
$\mathrm{NB}+\mathrm{NE}+\mathrm{F}$ & 220 & 89 & 89 & 2.8 & 2.2 \\
\hline
\end{tabular}

Correlation (Fscar and DI)

0.93

Fscar $=$ Feeding scar; DAI $=$ days after infestation

Treatments: C (control treatment), F (only A. alternata), NB+F ( $N$. bruchi alone augmented with $A$. alternata), $\mathrm{NE}+\mathrm{F}$ ( $N$. eichhorniae alone augmented with $A$. alternata and $\mathrm{NB}+\mathrm{NE}+\mathrm{F}$ (both weevil species augmented with $A$. alternata). 
pathogens and facilitated infection of water hyacinth (e.g., Charudattan et al., 1978). Moran (2005) reported that leaf scarring by the weevils N. eichhorniae and N. Bruchi enhanced efficiency of the pathogen $C$. piaropi to cause disease on water hyacinth leaves. Ajuonu et al. (2003) reported an increase in disease caused by M. rodidum, with an increase in the number of feeding scars of adult weevils.

\subsubsection{Effect on vegetative growth and inflorescence}

The effects of release of Neochetina weevils augmented with the fungal pathogen $A$. alternata on the number of ramets, the number of leaves and the number of inflorescences were significant $(\mathrm{P}<0.05)$ (Figure 7.2A, B, C). Water hyacinth plant treated with Neochetina weevils alone as well as augmented with A. alternata showed a significant negative effect on the reproductive potential of the water hyacinth plant. Petiole length is one of the best proxies of the impact of stress applied to water hyacinth. The percentage petiole length reduction by application of Neochetina weevils augmented with $A$. alternata followed a similar pattern as that with the number of leaves (Figure 7.2B). However, since individual weevil species only destroyed a fraction of each petiole, the percentage of petiole length destroyed by the respective weevils was rather low compared to the proportion of petiole length affected by the individual weevil species augmented with A. alternata. Moran (2005) reported that inoculation of C. piaropi augmented with Neochetina weevils had $20 \%$ lower live leaf counts per plant and 38\% lower plant densities than control plots.

The average numbers of ramets, leaves and inflorescences per plant recorded during week 8 were $0.45,0.63$ and 0.1 (Figure 7.2A, B, C), respectively, in water hyacinth plants treated with both Neochetina weevils augmented with A. alternata. These values were significantly lower $(\mathrm{P}<0.05)$ than plants treated with $N$. bruchi or $N$. eichhorniae augmented with $A$. alternata as well as in those treated with the combined application of Neochetina weevils. However, both weevil species restricted flowering in a similar way when combined and when individual weevil species were augmented with A. alternata (Figure 7.2C). Eight weeks after establishment of insects and pathogens, the number of green leaves per plant diminished by $95 \%$ and the number of new ramets was reduced by $97 \%$ due to combined application of the two weevils with A. alternata.

The present findings indicate that reduced vegetative growth by application of both weevils augmented with $A$. alternata led to reduced vigour. Similarly, Martinez and Gomez (2007) indicated that combined application of Neochetina weevils with $A$. zonatum showed $65 \%$ reduction in number of green leaves and $85 \%$ reduction in new ramets. 


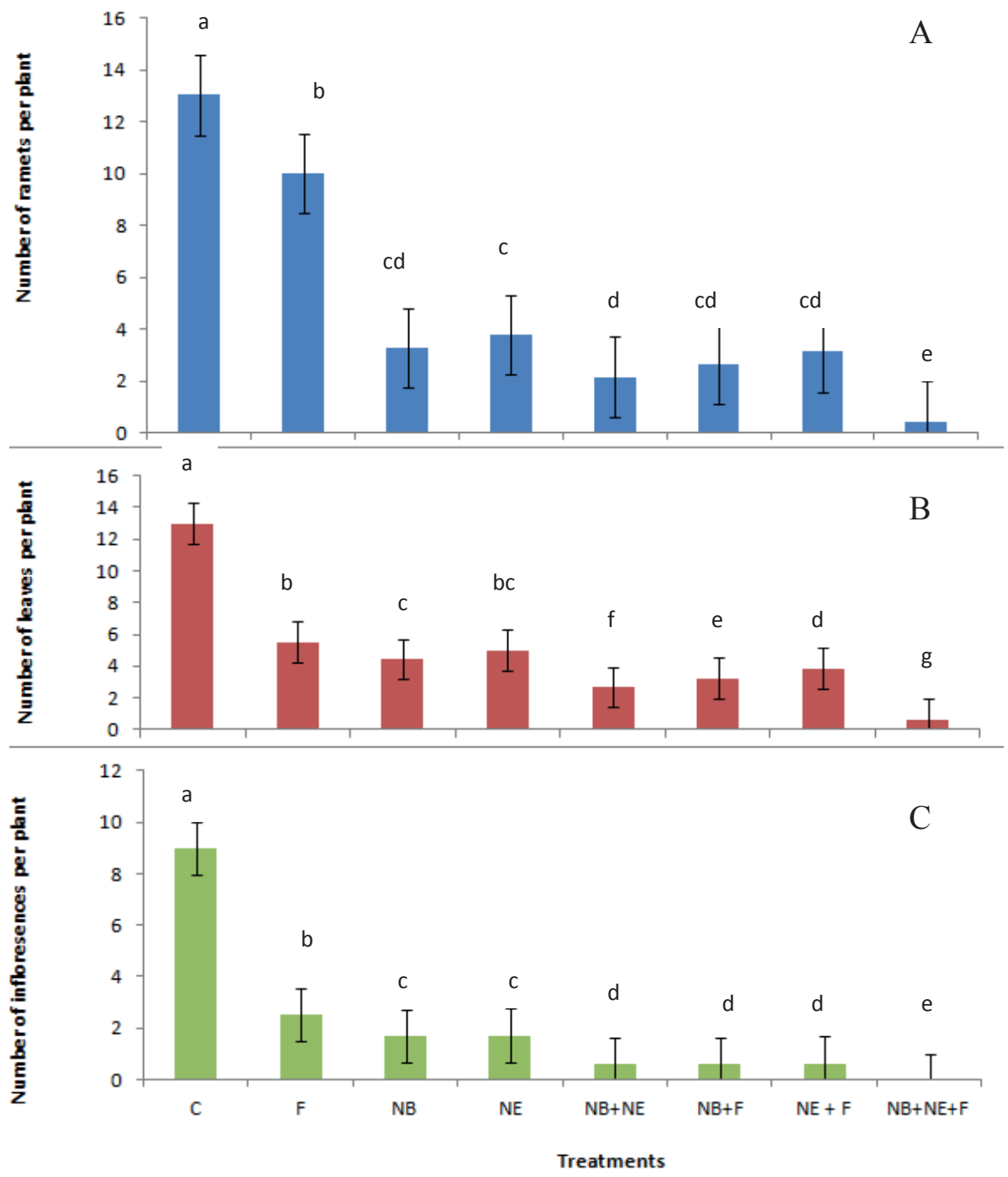

Figure 7.2. Impact of herbivory by Neochetina weevils augmented with the fungal pathogen A. alternata after eight weeks on the mean number of ramets (A), leaves (B), and inflorescences (C). Treatments: C (control), F (applying only Alternaria alternata), NB (applying only $N$. bruchi), NE (applying only $N$. eichhorniae), NB+NE (applying both weevil species), NB+F ( $N$. bruchi augmented with A. alternata), NE+F (N. eichhorniae augmented with $A$. alternata and $\mathrm{NB}+\mathrm{NE}+\mathrm{F}$ (both weevil species augmented with $A$. alternata). Means compared by two-way ANOVA; those with the same letter were not significantly different (Fisher's honest, $\mathrm{P}<0.05$ ). Error bars represent the standard error of the mean. 
Leaf number and ramet production are among the critical growth factors that affect water hyacinth survival (Center and Van, 1989; Heard and Winterton, 2000; Coetzee et al., 2007). Vegetative multiplication is key for the density and spread of water hyacinth populations. Therefore, a reduction in this reproductive mechanism would reduce expansion of water hyacinth mats and reduce its invasiveness (Byrne et al., 2010).

Hatcher (1995) and Turner et al. (2010) indicated that the interaction between the agents may be synergistic, additive, equivalent or inhibitory. The present study revealed that whilst the weevils were predominantly responsible for the greatest control of the vegetative growth of water hyacinth, the pathogen, A. alternata played a predominant role in reducing vegetative reproduction and inflorescence development. Combining the impacts of the three agents acting together on different sexual and asexual growth variables led to an overall synergistic effect on the damage caused to water hyacinth.

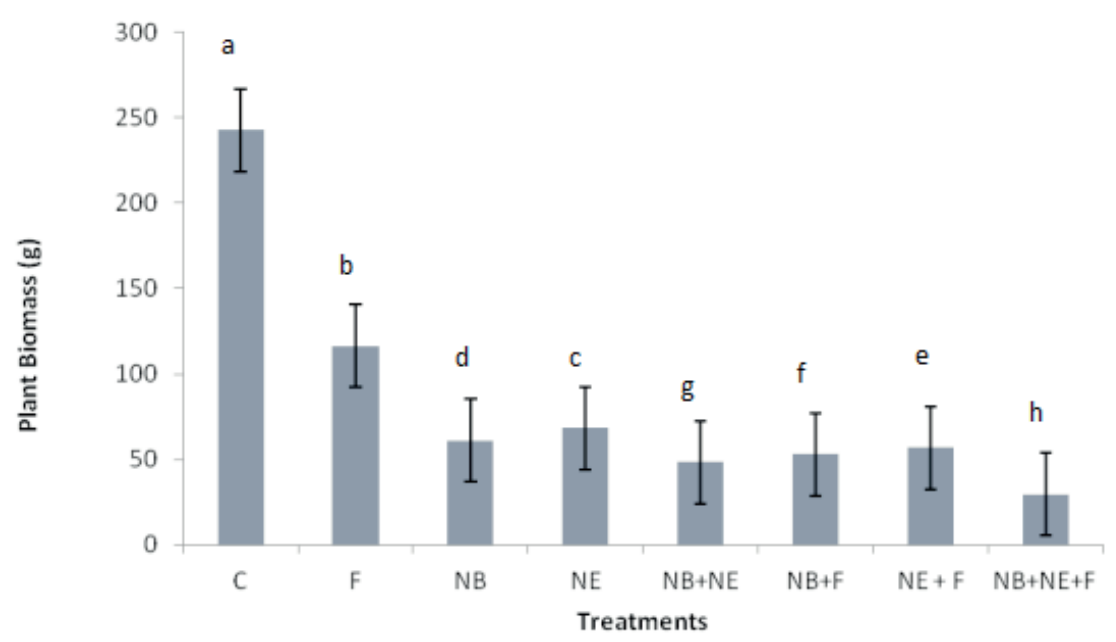

Figure 7.3. Impact of herbivory by Neochetina weevils augmented with the fungal pathogen A. alternata on plant biomass. Treatments: C (control), F (applying only Alternaria alternata), NB (applying only N. bruchi), NE (applying only N. eichhorniae), NB+NE (applying both weevil species), NB+F (N. bruchi augmented with $A$. alternata), NE+F ( $N$. eichhorniae augmented with $A$. alternata and $\mathrm{NB}+\mathrm{NE}+\mathrm{F}$ (both weevil species augmented with A. alternata). Means compared by two-way ANOVA; those with the same letter were not significantly different (Fisher's honest, $\mathrm{P}<0.05$ ). Error bars represent the standard error of the mean. 


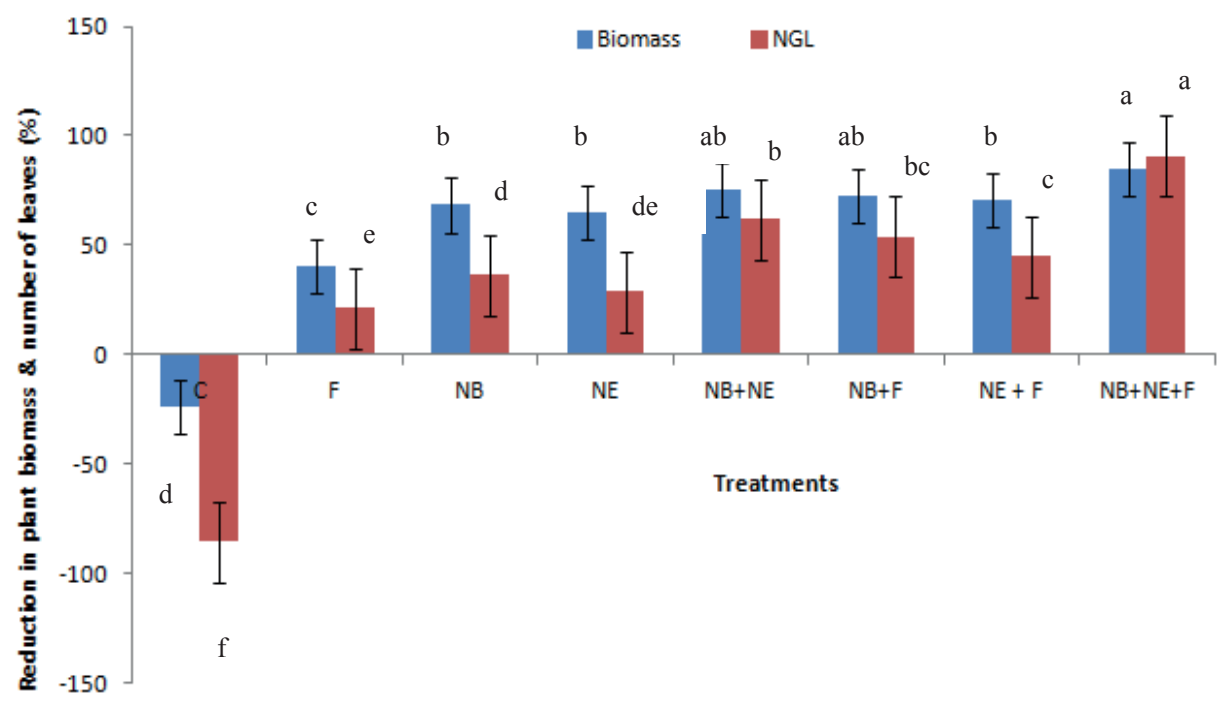

Figure 7.4. Impact of herbivory by Neochetina weevils augmented with the fungal pathogen A. alternata on plant biomass and number of green leaves (NGL). Treatments: C (control), F (applying only Alternaria alternata), NB (applying only $N$. bruchi), NE (applying only $N$. eichhorniae), NB+NE (applying both weevil species), NB+F (N. bruchi augmented with $A$. alternata), $\mathrm{NE}+\mathrm{F}$ ( $N$. eichhorniae augmented with $A$. alternata) and $\mathrm{NB}+\mathrm{NE}+\mathrm{F}$ (both weevil species augmented with $A$. alternata). Means compared by two-way ANOVA; those with the same letter were not significantly different (Fisher's honest, $\mathrm{P}<0.05$ ). Error bars represent the standard error of the mean.

\subsubsection{Effects on plant fresh weight}

Plant fresh weight difference among the treatments was significant at 8 weeks after release of the herbivory treatments. Among the treatments, the fresh weight of the plants that received $A$. alternata and augmented release of the two weevils was very significantly reduced $(\mathrm{P}<0.01)$ as compared to the untreated plants (Figure 7.3 ). The plant weight difference among the herbivory treatments was more remarkable in plants that received all agents (weevils and fungal pathogens). In plants that received the two agents separately, the differences were low. Plant fresh weight was higher in plants that received only $A$. alternata than in plants that received weevils and application of weevils augmented with $A$. alternata, possibly because of no herbivory effect. Direct effects of herbivory on water hyacinth through biomass consumption and fungal 
pathogens through leaf and stem consumption have also been reported earlier to influence plant biomass (De Mazancourt and Loreau, 2000).

Plant fresh weight differed among treatments and was highest in the control treatment (no herbivory and no fungal application). Plants augmented with agents had $85 \%$ lower plant fresh weight than the control (Figure 7.4). Reduction in plant fresh weight was significantly higher $(\mathrm{P}<0.001)$ in plants with the two weevils augmented with $A$. alternata (mean $\pm \mathrm{SE} ; 84.6 \pm 1.94$ ) and plants that received only the weevils $(75.3 \pm 1.49)$ compared to plants that received only A. alternata. This indicates that the integrated effects of the weevils and the fungal pathogen plus feeding damage by Neochetina weevils created satisfactory stress on the plants to cause a very significant reduction in plant size and density. Similarly, Center and Van (1989) indicated that weevil herbivory resulted in a decrease in leaf and petiole length, an increase in leaf mortality and an overall reduction in plant biomass.

\subsection{Conclusion}

The two Neochetina weevils and the fungus $A$. alternata were together able to reduce the vegetative growth and fresh weight of water hyacinth plants considerably. The fungal pathogen inhibited plant growth, and this was exaggerated by leaf scarring of the weevils. In conclusion, the three agents together had an overall synergistic effect on water hyacinth control.

\section{Acknowledgements}

We acknowledge EIAR-UNEP-GEF and Ethiopian Sugar Corporation for funding this research work. We are grateful to Mr Ambachew Dametie, Mr Abiy Negese, and Mr Yohannes Zekarias for the technical support. 



\section{CHAPTER 8}

General discussion 


\section{Chapter 8}

\subsection{Introduction}

Water hyacinth (Eichhornia crassipes [Mart.] Solms) is an invasive, free-floating, alien weed that has spread into different water bodies and wetlands of Africa, Asia, the Western Hemisphere and Pacific regions (Julien, 2001). The weed has been recognized as one of the world's worst invasive water weeds (Patel, 2012) causing various problems to millions of users of water bodies and water resources. Although the weed is native to the Amazon basin, its attractive flowers played a significant role in the spread into a number of water bodies throughout the world (Center et al., 2002). In Africa, the weed has been established in most of the water bodies with significant impacts on the environment, economic activities and community livelihoods (CABI, 2015). Water hyacinth is a serious weed, not only because of its rapid growth rate through both sexual and asexual reproduction means but also due to the absence of natural enemies in the introduced habitats (Abdelrahim and Tawfig, 1984).

In Africa, where there is resistance to the use of herbicides, biological control is the only sustainable control option (Cilliers et al., 2003; Mbati and Neuenschwander, 2005). Accordingly, several insect bioagents have been imported into Africa to be used as classical bioagents against the weed (Cilliers et al., 2003; Ajuonu et al., 2007; Coetzee et al., 2011; Tipping et al., 2014). Among these insect bioagents released worldwide, two weevils, Neochetina eichhorniae (Warner) and N. bruchi Hustache (Coleoptera: Curculionidae) have been proven to be most effective (DeLoach and Cordo, 1976b; Center and Van, 1989; Center et al., 1999b). In addition, Shabana et al. (1995a) and Charudattan (2001) indicated that fungal pathogens showed highly effective controlling potential against water hyacinth under experimental (e.g. Egypt, Sudan, South Africa) and field (e.g. Florida, South Africa, Australia) conditions. Positive interactions between insect herbivores and plant pathogenic fungi are potentially useful in biological water hyacinth control. Combined use of biological control agents (bioagents) has been advocated as the best prospect for long-term management of aquatic weeds (Charudattan, 2001; Evans and Reeder, 2001). In line with that, the few attempts made so far to utilize this potential for the management of water hyacinth demonstrated the feasibility and commercial potential of augmenting weevils with pathogens (Moran and Graham, 2005; Martinez and Gomez, 2007).

In Ethiopia, water hyacinth continues to pose significant economic, social and environmental problems. These include hindrance to water transport, disrupting hydroelectric operations, blockage of canals and rivers, flooding, causing human health problems, increased evapotranspiration, interference with fishing, reduction in irrigation efficiency, navigation, livestock watering and biodiversity (Hailu et al., 2004; Kassahun et al., 2004; Senayit et al., 2004; Taye et al., 2009). The existing 
management strategy (i.e., manual as well as mechanical clearing and in some spots chemical control) was not effective to combat the various problems. However, no attempts have been made to include the use of bioagents in water hyacinth management. Consequently, the search for effective classical as well as native bioagents was the main driving force for this study. Thus, the main objective of this research was to develop an effective integrated water hyacinth control strategy through the use of insects and fungal pathogens, especially in lakes, dams, irrigation canals and reservoirs in the Rift Valley of Ethiopia.

This chapter summarizes and discusses the main findings of the study, compares findings of the study with established results in Africa and provides practical relevance of the study to Ethiopia as well as to the Lower Nile Basin Countries (Egypt and Sudan).

\subsection{Major findings of the study}

This section provides a brief overview of the main results. These results refer to new applicable knowledge for the understanding and management of this problematic aquatic weed by using fungal pathogens and weevils as bioagents in a sustainable way.

\subsubsection{Quantifying water hyacinth distribution}

The first step in the incorporation of biological control procedures is to initiate surveys for quantifying the existing plant infestation levels and population sizes. To accomplish this goal, a survey was conducted twice yearly between 2009 and 2011 . Among the surveyed water bodies, the highest water hyacinth infestation (4-5 on an abundance scale of 1-5) and visual area coverage (>90\%) were recorded in Lake Ellen and Lake Elltoke. The lowest water hyacinth infestation level (trace; 1 on the abundance scale) and area coverage $(<7 \%)$ were recorded at Wonji-Shoa and Lake Abaya (Chapter 2, Table 2.2). Moreover, 20-58\% cover of water hyacinth mat area was recorded at Aba-Samuel Dam, Koka Dam, Awash Dam, Lake Koka, irrigation water supplies and drainage structures found in Melka Hida, Taree, and Afer Gideb. Throughout all the three years of survey work, Lake Bishoftu, Lake Cheleleka, Lake Ziway, Lake Langano, Lake Shala, Lake Abiyata, Lake Awassa, Lake Chamo and Lake Beseka were free of the water hyacinth problem. The number of plants in the Rift Valley lakes, dams, irrigation water supplies and drainage structures varied from none to more than 300 plants per $\mathrm{m}^{2}$. Since the Aba-Samuel Dam is a major source of water hyacinth introduction into Lake Ellen, Lake Elltoke, Lake Koka, and Koka Dam, a collaborative biological control programme should be extended to cover the entire basin. 


\subsubsection{Use of climate-matching approach and existing opportunities to use Neochetina weevils as an integral part of water hyacinth management in Ethiopia}

During the field assessment, it was noted that except at Wonji and Koka Dam where manual, chemical (on limited water bodies) and mechanical control measures have been employed, no major management strategies had been employed in the infested water bodies. As a result, an increasing trend of water hyacinth invasion could be observed in the upstream water bodies. Therefore, our strategy was focussed on exploring native as well as classical bioagents for the sustainable management of water hyacinth. In this context, it was decided to evaluate first the existing opportunities for extending the use of Neochetina weevils in Ethiopia. Hence, before introducing the water hyacinth weevils, we have used a modelling tool, CLIMEX, to determine whether climate would be a limiting factor for establishment and spread of the weevils in Ethiopia. The results indicated that the hot and wet areas in Ethiopia would be the most suitable ones. The use of this predictive model (climate-matching approach) provides confidence that the projected distribution of the weevils in Ethiopia could be realistic and robust.

On the other hand, the model prediction for the weevils' distribution or adaptability in scenarios for climate change $\left(3^{\circ} \mathrm{C}\right.$ rise in temperature) resulted in an increase of the potential range throughout the northern and eastern parts of Ethiopia. In addition, by using a species climate-response model based on the Ecoclimatic Index (EI) as well as results from Climate Matching suggested that the two selected water hyacinth weevils could be valuable bioagents of water hyacinth in Ethiopia.

\subsubsection{Understanding ecological interactions of ambient factors, bioagents and water hyacinth}

Understanding the relationship of water hyacinth coverage with environmental and water quality factors is a key to determine the management actions. In light of water hyacinth management efforts, we have carried out correlation analyses between water quality factors and climatic factors on the one hand and water hyacinth coverage on the other. The analyses indicated significant associations between water quality factors and water hyacinth coverage as well as between climatic factors and water hyacinth coverage (Chapter 2, Table 2.3). Water hyacinth coverage was positively correlated with rainfall (RF), nutrient contents $(\mathrm{N}, \mathrm{P}$, and $\mathrm{K}$ ) and temperature $(\mathrm{T})$, and negatively correlated with depth of the water bodies and altitude. The N, P and K contents of the water bodies showed positive correlations with water hyacinth coverage at AbaSamuel Dam, Lake Ellen, Lake Elltoke, Lake Koka and Koka Dam, and Melka Hida. These water bodies are among the major sites where high levels of infestation and 
plant population were recorded. Similarly, Center et al. (2014) confirmed that the invasive ability of water hyacinth is attributable to plant and water quality factors, especially in eutrophic systems. Reddy et al. (1991) also reported that optimum growth of water hyacinth occurs in slowly moving water and high relative air humidity, long sun exposure, a $\mathrm{pH}$ of 7 , a temperature range between $28^{\circ} \mathrm{C}$ and $30{ }^{\circ} \mathrm{C}$, and sufficient N, P and K supply.

On the other hand, performance of Neochetina weevils against water hyacinth was profoundly affected by plant quality (Center et al., 2002, 2005; Moran, 2006; Center and Dray, 2010; Center et al., 2014). Weevil populations grow larger and more quickly on plants in nutrient-rich environments where water hyacinth productivity is also enhanced. Water hyacinth plants that have grown at higher nutrient concentrations are superior hosts for N. bruchi compared to N. eichhorniae (Heard and Winterton, 2000). Our plant quality analysis data suggest that most of water hyacinth-prone areas of Ethiopia had adequate nutrient levels for growth and development of water hyacinth. This indicated that plant quality would not be a limiting factor for a good establishment of the bioagents. This has also been demonstrated by the increase over time of the two weevil populations in the adaptability study (Chapter 5, Figures 5.2 and 5.3), as expressed by the variables net reproductive rate, intrinsic rate of increase, and enhanced reproductive performance of the two weevils (Chapter 5, Table 5.2). However, nutrient availability varies from one aquatic system into another. Thus, prior to introduction or release of the weevils, assessment of plant quality and water quality is crucial for successful establishment of the weevils.

\subsubsection{Quantifying the density of the two Neochetina weevils required to control water hyacinth}

Effects of different densities of the two weevils on water hyacinth growth and plant biomass indicated that weevil herbivory were expressed in decreased leaf and petiole lengths, increased leaf mortality and overall reduction in plant biomass. The plants were significantly affected by different densities of the two weevils and their combined application at eight weeks after release of the herbivory treatments (Chapter 6, Table 6.2). Three pairs of $N$. bruchi resulted in the greatest reduction of water hyacinth plant weight when combined with two or three pairs of $N$. eichhorniae. Evaluation of the density-damage associations between the weevils and the water hyacinth biomass indicated a curvilinear relationship between its final biomass as a function of increasing levels of herbivory (Chapter 6, Figure 6.3). The observed relationship between weevil density and water hyacinth biomass reduction could be well described by a negative log function $\left(\mathrm{R}^{2}=0.98\right)$. Reduction in water hyacinth's ability to compensate for herbivory was a linear or curvilinear function of insect 
density, which is a relationship commonly observed between plants and phytophagous insects (Meyer, 1998; Schooler and McEvoy, 2006; Stanley et al., 2007). Similarly, the present findings indicated that herbivory loads greater than one weevil per plant were sufficient to cause significant biomass reductions with a maximum recorded at a density of 6 weevils plant ${ }^{-1}$. In our adaptability study, for both species more than 6 weevils plant ${ }^{-1}$ have been recorded (Firehun et al., 2015). Thus, assessment of the optimum densities of the two weevil species for release in the Rift Valley of Ethiopia satisfies the requirements stated by McClay and Balciunas (2005) for a promising biocontrol agent, although a candidate is only justified for release if it has the ability to reduce fitness of its host plant at realistic field densities.

Moreover, the change in fresh weight of water hyacinth plants from week 1 to week 8 was significantly different between all herbivory treatments and the control ( $\mathrm{P}<0.0001)$ (Figure 8.1). However, the extent of change in weight loss varied with densities and weevil species. Change in weight due to the herbivory treatment ranged from $-13 \%$ by one pair of $N$. eichhorniae alone to $-67 \%$ by three pairs of $N$. bruchi when combined with two pairs of N. eichhorniae (Figure 8.1). The extent of change in weight observed in our study was much greater than the losses reported by Del Fosse (1978), who showed changes that ranged between -5 to $-50 \%$ where weevils were

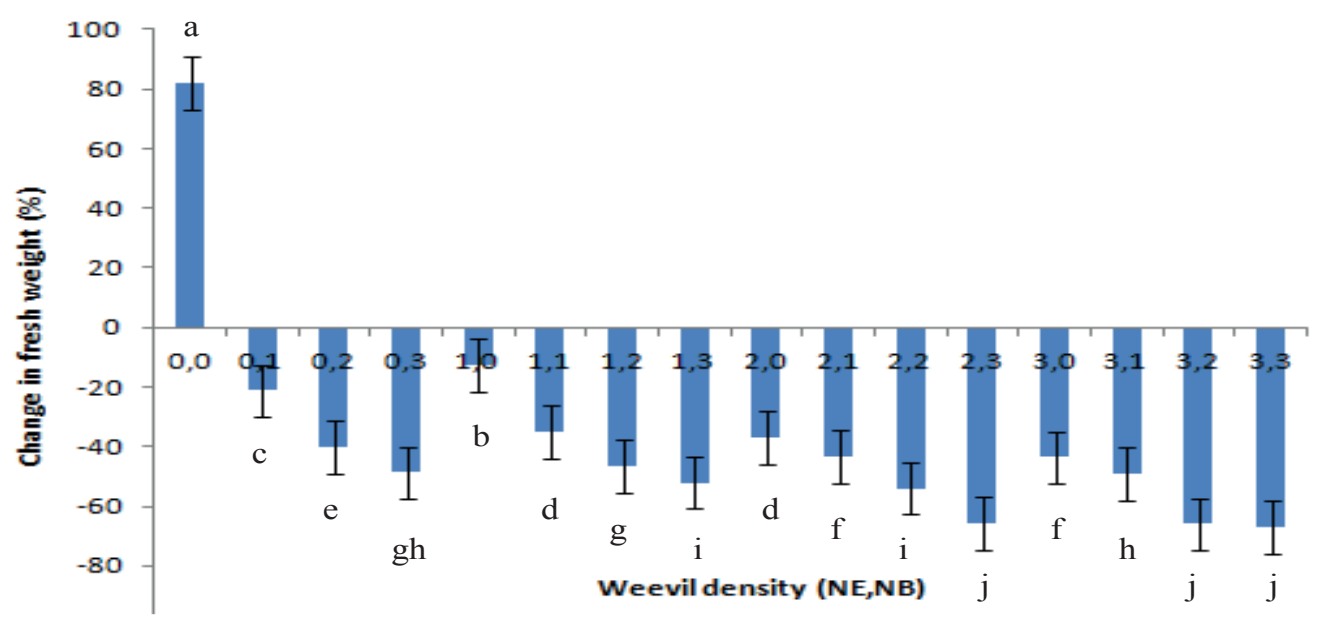

Figure 8.1. Changes in fresh weight of water hyacinth plants from Week 1 to Week 8 in the herbivory treatments and the control. Herbivory treatments included densities of 1,2 and 3 pairs of N. eichhorniae (NE) and N. bruchi (NB). Means compared by one-way ANOVA; those with the same letter are not significantly different (Tukey's HSD, $\mathrm{P}<0.05$ ). Error bars represent the standard error of the mean. 
allowed to interfere with water hyacinth. This might be attributed to the use of only single species in that study as opposed to evaluation of combined effects of two mottled weevils in the current study.

\subsubsection{Methodological challenges to protocol standards and their application: Significance of Neochetina weevil pre-release evaluation and host specificity tests}

\subsubsection{Significance of weevil pre-release efficacy test}

The study on the life cycle and development of Neochetina weevils indicated that the egg hatching period of $N$. bruchi ranged from 4 to 10 days, while $N$. eichhorniae took 8-12 days. Larvae of $N$. bruchi took a comparatively shorter period (32-38 days) than N. eichhorniae (52-60 days) to complete their development (Chapter 5). The present study on the reproductive potential and population increase of the two weevils indicated that the intrinsic rate of increase of $N$. bruchi appeared to be 0.060 with a generation time of 74.8 days and a population doubling period of 14.4 days. The intrinsic rate of increase of $N$. eichhorniae was 0.046 accompanied by a generation time of 94.8 days and a doubling period of 18.6 days (Chapter 5). Moreover, our study about the oviposition behaviour of Neochetina weevils on water hyacinth indicated that $N$. bruchi and $N$. eichhorniae females oviposited a total number of $359 \pm 14$ eggs and $299 \pm 36$ eggs during their lifespan, respectively (Chapter 5, Table 5.2).

Based on the obtained results regarding developmental time, population increase and fecundity factors, it appears logical to recommend large scale release of $N$. bruchi. However, since (i) the larva stage caused the most damage to the water hyacinth and (ii) N. eichhorniae took a comparatively longer period to complete the larval stage, we suspected better larval damage from $N$. eichhorniae than from $N$. bruchi. We therefore hypothesized that the difference in the larval developmental period between the two species indicates the potential for combined use of the two species in large scale management of water hyacinth. We also hypothesized, based on earlier observations (Center and Dray, 1992; Center et al., 1999), that the two weevil species respond differently. To address these hypotheses, we have carried out a pre-release evaluation of efficacy of the two weevil species at different densities. The results revealed that the combined release of $N$. bruchi and $N$. eichhorniae showed significantly higher growth suppression as expressed in petiole length and biomass of water hyacinth (both fresh and dry weight) than $N$. bruchi and $N$. eichhorniae alone (Chapter 6, Figures 6.1D, E, F). Among the different combinations, the lowest number of ramets and leaves was recorded in case of three pairs of $N$. bruchi when combined with two pairs of $N$. eichhorniae, followed by three pairs of $N$. eichhorniae combined with two as well as three pairs of $N$. bruchi. However, no difference was observed regarding numbers of 


\section{Chapter 8}

remaining ramets and leaves in the combined application of three pairs of N. bruchi with two and three pairs of $N$. eichhorniae. Leaf number and ramet production are among the most critical growth factors that limit water hyacinth survival (Center and Van, 1989; Heard and Winterton, 2000; Coetzee et al., 2007) and are therefore proper parameters to evaluate the impact of weevil herbivory. Asexual reproduction by water hyacinth is important in the density and spread of water hyacinth populations. Therefore, a reduction in productivity would reduce expansion of water hyacinth mats and reduce its invasive potential (Byrne et al., 2010). The herbivory effect of the combined application on number of leaves and ramets would also affect the plant photosynthetic capacity and its buoyancy capability. Hence, this combined herbivory effect of the two weevils would reduce the expansion rate of the weed.

In conclusion, our study revealed that the combined release of the two weevils showed better reduction in the reproductive potential and vigor of the water hyacinth plants. This could be attributed to the co-existence of the two weevil species in water hyacinth plants as well as the complementary effects of the different growth stages of the respective weevil species (i.e., larvae and adult).

Summarizing, in contrast to earlier predictions (Firehun et al., 2015) where $N$. bruchi had greater intrinsic rate of increase, fecundity and plant damage than $N$. eichhorniae, we recommend strongly the combined release of the two weevils (Firehun et al., 2016). Thus, the present study reaffirms the need for pre-release evaluation on efficacy of weed biological control agents so as to avoid introduction of ineffective agents into the environment.

\subsubsection{Significance of weevils host-specificity test}

The host-range assessment study revealed that $N$. eichhorniae and $N$. bruchi were restricted to the aquatic plant water hyacinth family (Pontederiaceae). Even families allied to or very closely related to Pontederiaceae, namely Asteraceae and Commelinaceae, appeared to be not suitable for their development and survival. Absence of adult survival and feeding over were recorded on non-Pontederiaceae plants and no progeny was produced on E. natans (Pontederiaceae), Pistia stratiotes (Araceae) and Brassica oleracea (Brassicaceae), providing evidence that they are not suitable hosts (Chapter 6, Table 6.3).

Neochetina eichhorniae and N. bruchi have been released on water hyacinth in 30 and 27 countries, respectively (Center et al., 2002). Both weevils have been subjected to extensive screening and tested against 274 plant species in 77 families worldwide (Julien et al., 1999). The result indicated that both weevils have a narrow host range and they can only complete their pupation stage underwater. The pupation behaviour of these insects, during which they develop a pupal cocoon in the roots of floating 
water hyacinth, makes it highly unlikely that any substrate rooted plant could serve as a suitable host (Julien et al., 1999; Center et al., 2002).

Moreover, since 1972 when the two weevils had been released in USA, there is no adverse report about attacks on non-target plants in any of the countries where the agents have been released. Therefore, the need/relevance of such rigorous confirmatory test particularly on terrestrial crops becomes questionable. Hence, future research activities need to check the need for confirmatory tests on terrestrial crops so as to avoid redundant efforts of evaluating protocols.

\subsubsection{Findings in Ethiopia in relation to other African countries: Climatic adaptability and life cycle}

Syrett et al. (2000) found that eco-climatic mismatching is the principal factor that may cause biological control agents' failure to establish. The results of climate matching analysis indicated that the water hyacinth weevils can permanently inhabit western and eastern parts of Africa (Chapter 3, Figure 3.2B). Field observations support this prediction, because the weevils successfully established in the eastern part (Uganda, Kenya and Tanzania) and the western part (Nigeria, Niger, Ghana, Benin) of Africa (Ochiel et al., 2001; Ajuonu et al., 2003; Cilliers et al., 2003; Ogwang and Molo, 2004). The variability of climatic conditions in South Africa results in a significant and negative effect on successful establishment of Neochetina weevils (Byrne et al., 2010). Hence, when deliberate introductions of bioagents are made for management of water hyacinth, it is necessary to understand how climate factors can affect success of the biological entity. For this purpose, a predictive model (e.g. CLIMEX; climate-matching approach) can be considered as part of the pre-release assessment protocols. Application of such protocols would save time, money, energy and other resources.

DeLoach and Cordo (1976b) and Julien et al. (2001) reported that the developmental period required by the two weevils varied from country to country and from region to region depending on the prevailing climatic conditions. The results of our life cycle and development studies also indicated that the two weevils took shorter generation time in Ethiopia than in Argentina (DeLoach and Cordo, 1976b) but a relatively similar generation time as in the two East African countries (Ogwang and Molo, 1997; Nijoka, 2001). However, higher adult longevity has been recorded under Ethiopian conditions as compared to the two East African countries. We contend that the variation in adult longevity could result from differences in climatic conditions and plant quality. These results also have implications for herbivory effects of the weevils, which could lead to effective biological control of the weed. 
In Ethiopia, data on the developmental threshold and degree-day requirements (CLIMEX PDD parameter) indicated that the two weevils could complete more than four generations per year. Field studies conducted in Ethiopia, Kenya and Uganda confirmed that the two weevils produced four generations per year (Ogwang and Molo, 1997; Nijoka, 2001; Firehun et al., 2015). However, in South Africa, the two weevils were not able to complete more than one generation due to the cold winter (Hill and Olckers, 2001). This confirms the importance of climate for successful establishment of the two bioagents.

\subsubsection{Exploration of native fungal pathogens and the synergy with Neochetina weevils in water hyacinth management}

Biological control of weeds using plant pathogens has gained acceptance as a practical, safe, and environmentally beneficial weed management method applicable to agro-ecosystems (Charudattan, 2001). In this regard, our survey identified 25 fungal species found in association with water hyacinth. Both morphological and molecular analyses showed that the fungal isolates belonged to nine genera (Chapter 4, Table 4.3). Among the fungal pathogens, A. alternata, A. tenuissima, Phoma sp., Alternaria sp., F. oxysporum, and $F$. equiseti were the most common species reported as pathogens of water hyacinth. Alternaria alternata has been described as a pathogen of water hyacinth in Australia (Galbraith, 1987), Egypt (Shabana et al., 1995a, b; ElMorsy, 2004; El-Morsy et al., 2006), Bangladesh (Bardur-ud-Din, 1978) and India (Aneja and Singh, 1989; Mohan et al., 2002, 2003). Despite the occurrence of several fungal species on water hyacinth in Ethiopia, Curvularia trifolii, M. fragilis, $M$. racemosus, A. fumigatus, Botryosphaeria sp. and $N$. parvum have not been previously isolated from water hyacinth. Based on the analysis of data on pathogenicity, hostrange, and association with environmental and water factors, A. alternata and $A$. tenuissima hold promise as possible biocontrol agents of water hyacinth.

Taking into consideration the prevalence of host-specific native fungal pathogens and adaptability of the two weevils, we evaluated the integrated use of Neochetina weevils and an indigenous plant pathogen (A. alternata) in controlling water hyacinth. The average numbers of ramets, leaves and inflorescences per plant recorded during week 8 were $0.45,0.63$ and 0.10 (Chapter 7, Figure 7.2A, B, C), respectively, in water hyacinth plants treated with both Neochetina weevils augmented with A. alternata. These values were significantly lower than in plants treated with $N$. bruchi or $N$. eichhorniae augmented with $A$. alternata as well as in those treated with the combined application of Neochetina weevils. However, both weevil species restricted flowering in a similar way when combined and when individual weevil species were augmented with $A$. alternata (Chapter 7, Figure 7.2C). Eight weeks after establishment of insects 
and pathogens, the number of green leaves per plant diminished by $95 \%$ and the number of new ramets was reduced by $97 \%$ due to combined application of the two weevils with $A$. alternata.

Plants augmented with both agents had $85 \%$ lower plant fresh weight than in the control (Chapter 7, Figure 7.4). Reduction in plant fresh weight was significantly higher in plants with the two weevils augmented with $A$. alternata (mean $\pm \mathrm{SE} ; 84.6 \%$ $\pm 1.94 \%)$ and plants that received only the weevils $(75.3 \% \pm 1.49 \%)$ compared with plants that received only $A$. alternata. This indicates that the integrated effects of the weevils and the fungal pathogen plus feeding damage by Neochetina weevils created satisfactory stress on the plants to cause a very significant reduction in plant size and density. Similarly, Center and Van (1989) indicated that weevil herbivory resulted in a decrease in leaf and petiole length, an increase in leaf mortality and an overall reduction in plant biomass.

\subsection{Practical relevance and application of the research}

\subsubsection{For sustainable water hyacinth management at Wonji-Shoa sugar factory}

Water hyacinth was first observed on the irrigation and drainage canals of Wonji-Shoa sugar factory in 1996 (Firehun et al., 2007). A survey conducted in 2006 indicated that this noxious aquatic weed infested a total of 116.4 ha of water bodies. In 2006/2007, an integrated (manual, mechanical and chemical) control strategy had been exercised.

A survey conducted from 2009 to 2011 indicated that the level of infestation has significantly reduced from 116 ha to less than 7 ha (Chapter 2, Figure 2.2). Moreover, the control strategy enabled the factory to maintain more than 88 ha of water bodies free of this weed. However, during the survey, we noted that there was a rapid increase in the level of infestation in the upstream water bodies, mainly Koka Dam and Aba Samuel Dam, which are the major sources of water hyacinth introduction to the factory. This indicates, yet, that the sustainability of the success achieved at WonjiShoa is not guaranteed as the upstream water bodies are still infested with the weed and its extent of invasion increased over the years. Thus, in order to ensure sustainability of the present success, it is vital to have an effective management strategy on site as well as in the upstream water bodies. Use of the two Neochetina weevils and fungal pathogen in the upstream water bodies will enable to maintain the water hyacinth infestation below the threshold level, which subsequently will reduce the associated re-infestation risk to the downstream water bodies. Hence, implementation of the findings of this study will enable to manage the weed from the source in a sustainable manner. 


\subsubsection{For prevention of water hyacinth invasion in Ethiopian Rift Valley Lakes}

During the survey work of this thesis it appeared that with the exception of Lake Ellen, Lake Elltoke, Lake Abaya and Lake Koka, all the other lakes (i.e., Lake Bishoftu, Lake Cheleleka, Lake Ziway, Lake Abiyata, Lake Shala, Lake Langano, Lake Awassa, Lake Chamo and Lake Beseka) were free of the water hyacinth problem. This could be associated with the fact that some of the latter lakes could be considered as closed ones (e.g., Lake Shala, Lake Beseka) whilst the others are fed by water hyacinth free water bodies (i.e., Lake Ziway, Lake Abiyata, Lake Awassa, and Lake Chamo). However, lakes in Ethiopia are often adjacent to one or more urban areas, along with farmers and other resource users drawing their livelihoods from the lake and surrounding land (i.e., for agro-industry, agriculture and fishing). Thus, there is no assurance that these water bodies will remain free of water hyacinth in the near future without taking preventive control measures, which also include managing the upstream water bodies.

On the other hand, implementation of the findings of this study on a large scale will contribute to a restricted distribution of the weed to only those water bodies where the weed has already been spread. Consequently, this significantly reduces the risk of water hyacinth infestation to the above-mentioned lakes.

\subsubsection{To mitigate the risk of water hyacinth expansion to the Blue Nile River and downstream dam}

Lake Tana is valuable for millions of people, including the communities who live around the lakeshore and those living on islands as well as close to the Blue Nile River, which flows from it. The area has been identified as a region for irrigation and hydro-power development, vital for food security and economic growth in Ethiopia. Recently, water hyacinth infestation has also been observed in Lake Tana (UNESCO's Biosphere Reserve site for its rich biodiversity). The current estimate of water hyacinth infestation coverage is ca. 34,500 ha $(3,000$ ha thick, 2,500 ha intermediate and 29,000 ha scattered).

To mitigate the situation, as a quick fix strategy, physical control measures have been implemented by the Regional Authority. However, it was not possible to manage the problem. Rather it is expanding at an alarming rate. Prediction of the weevils' distribution or adaptability confirmed the potential to use the weevils in northern and eastern parts of Ethiopia (Chapter 3). Moreover, our results of feeding and no-choice oviposition tests for $N$. eichhorniae and $N$. bruchi confirmed that the weevils are sufficiently host-specific and, therefore, can be safely released (Chapter 7). Thus, with large scale application of the two weevils, it is possible to control this weed in a sustainable way. This is especially important to mitigate the risk of expansion to 
invade the Blue Nile River and consequently affect the Ethiopian Great Renaissance hydro-electric dam reservoir.

However, since biological control is a relatively new concept, communities living around the lake basin should be trained in weevil mass rearing and subsequent releasing techniques. The use of weevils can be supplemented with artificial inoculation of fungal pathogens through mass production of fungal spores. Since the weed thrives well in the nutrient loaded lake entry sites, the release of the weevils should also be extended to river mouths emptying into the lake.

\subsubsection{To mitigate the risk of water hyacinth expansion to the Lower Nile Basin countries (Egypt and Sudan) and riparian communities}

The Lower Nile Basin waterways of Egypt, Sudan, and Ethiopia are interconnected. The Blue Nile rises at Lake Tana in the Ethiopian highlands and joins the White Nile at Kartum (Appelgren et al., 2000). This involves that weed infestation in the Ethiopian Highlands (Lake Tana, Sobate, Baro and Gillo River) will ultimately infect the others. On the other hand, organisms added to one for the biological control of aquatic weeds could eventually spread to the others. Currently, infestation of water hyacinth has been manifested on a large scale in many water bodies of the Gambella area (Sobate, Baro and Gillo River), and Lake Tana (Rezene, 2012). Besides, we should take into account that the Blue Nile contributes 70 to $90 \%$ of the total Nile's low and peak water flow (Appelgren et al., 2000).

Studies conducted in the Upper White Nile Basin (Lake Victoria) indicated that the flow of water in the Nile could be reduced by up to one tenth due to increased losses from evapotranspiration caused by water hyacinth in Lake Victoria (Ndimele et al., 2011). Expected water losses by the same process and blocking of turbines for power generation on Kafue Gorge in Zambia can be translated into lost revenues of about US\$15 million every year for the power company (ZEO, 2008). Thus, to avoid future water hyacinth explosions into the Lower Nile Basin countries (Egypt and Sudan), a concerted effort among the Nile Basin countries is crucial. Beyond this, taking the significance of the problem, it would be worthwhile for researchers to exchange information periodically on aquatic weed problems and on the successes and challenges encountered in dealing with them. Hence, large scale application of the two weevils at Lake Tana will benefit the Lower Nile Basin countries (Egypt and Sudan) and riparian communities. 


\subsubsection{Societal relevance of water hyacinth management using bioagents}

Water hyacinth obstructs electricity generation, irrigation, navigation, and fishing. It increases water losses due to evapotranspiration and also facilitates proliferation of diseases such as bilharzias. These consequences have resulted already in very serious social, economic and environmental problems for millions of people in the riparian communities of Ethiopia and Lower Nile Basin countries. Thus, management of this weed with the use of the two Neochetina weevils would have significant impact to the riparian communities that live and derive direct benefits from the affected water sources. Moreover, by implementing a community-based strategy, where the communities would participate in mass rearing and release of the bioagents, it is possible to benefit them. As a result of this strategy, the community will also benefit through the creation of new employment opportunities (i.e., rearing and distribution) and, consequently, improved standards of living.

\subsection{Key recommendations}

Based on the findings of this study, the following key management actions are proposed to control water hyacinth in a sustainable way using fungal pathogens and weevils as bioagents:

- Since Aba-Samuel Dam is a major source of water hyacinth introduction into Lake Ellen, Lake Elltoke, Lake Koka, and Koka Dam, a collaborative and integrated biological control programme should be extended to cover the entire Awash River basin (Chapter 2);

- Taking into account the significance of climate for the success of the two weevils, it is advisable to make use of a predictive model (e.g. CLIMEX; climate-matching approach) as part of the pre-release assessment protocol (Chapter 3);

- Among the fungal pathogens, A. alternata and A. tenuissima are recommended as possible biocontrol agents of water hyacinth (Chapter 4);

- Both N. eichhorniae and N. bruchi are recommended to be released together in large scale management programs of water hyacinth (Chapter 5 and Chapter 6) at herbivory loads of the weevils greater than one weevil per plant (Chapter 6);

- Both $N$. eichhorniae and N. bruchi are sufficiently host specific and, therefore, can be safely released for the management of water hyacinth (Chapter 6); and

- Taking into account the synergy between fungal pathogens and the two weevil species it is advisable to augment the large scale release of the two weevils with fungal pathogens (Chapter 7). 
All of the above-mentioned management measures have great potential to establish environmentally-friendly, cost-effective and sustainable biological management strategies against water hyacinth. Implementation of the above recommendations will benefit:

(i) the riparian community whose life mainly depends on the water bodies affected by water hyacinth;

(ii) agro-processing industries established along the Awash River; and

(iii) hydro-power stations established in the Rift Valley of Ethiopia.

In addition to the Rift Valley water bodies, large scale release of the two weevils is indispensable for Lake Tana and Lower Nile Basin countries (Egypt and Sudan) as well as the riparian communities along the Basin.

\subsection{Suggestions for future research}

The main aim of this thesis was to develop an effective integrated water hyacinth control strategy by using fungal pathogens and weevils as bioagents in a sustainable way. Based on the results of the current study, I believe that further work is still needed for a better understanding and optimization of water hyacinth management using bioagents. Thus, the following major future research areas are recommended as a follow-up of this thesis work, namely:

- To simplify large scale application of the fungal pathogens there is a need to develop a formulation/mycoherbicide for the fungal pathogens that shows better efficacy and safety;

- As demonstrated in the current study, there exists a clear synergy between fungal pathogens and the two weevil species, but there is still a need to investigate in greater detail the effects of combined application of two or more fungal pathogens together with the two weevil species; and

- Although the joint use of the two weevil species and fungal pathogens showed better efficacy and safety, there is a need to solve the practical challenges related to mass production of inocula and the two weevils species. 



\section{References}

Abdelrahim, A.M., and S. Tawfig (1984). Pathogenicity of fungi and bacteria from the Sudan to water hyacinth. Weed Research, 24(4):233-238.

Adkins, S. (1997). Introduction to weed science. In: Julien, M., and G. White (Eds.), Biological control of weeds: Theory and practices. Australian Centre for International Agricultural Research, Bruce, ACT, Australia, pp. 23-38.

Aguilar, J.A., O.M. Camarena, T.D. Center, and G. Bojorquez (2003). Biological control of water hyacinth in Sinaloa, Mexico with weevils Neochetina eichhorniae and N. bruchi. BioControl, 48:595-608.

Ainsworth, G.C., F.K. Sparrow, and A.S. Sussman (1973). The Fungi, Vol. IVA. Academic Press, New York, 621 pp.

Ajuonu, O., V. Schade, B. Veltman, K. Sedjro, and P. Neuenschwander (2003). Impact of the exotic weevils Neochetina spp. (Coleoptera: Crculionidae) on water hyacinth, Eichhornia crassipes (Lil: Pontenderiaceae) in Benin, West Africa. African Entomology, 11:153-161.

Ajuonu, O., M. Byrne, M.P. Hill, P. Neuenschwander, and S. Korie (2007). Survival of the mirid Eccritotarsus catarinensis as influenced by Neochetina eichhorniae and Neochetina bruchi feeding scars on leaves of water hyacinth Eichhornia crassipes. Biological Control, 52:193-205.

Ajuonu, O., M. Byrne, M.P. Hill, P. Neuenschwander, and S. Korie (2009). The effect of two biological agents, the weevil Neochetina eichhorniae and the mirid Eccritotarsus catarinensis on water hyacinth, Eichhornia crassipes, grown in culture with water lettuce, Pista stratiotes. Biocontrol, 54:155-162.

Albright, T.P., T.G. Moorhouse, and T.J. McNabb (2004). The rise and fall of water hyacinth in Lake Victoria and the Ksgera River Basin, 1989-2001. Journal of Aquatic Plant Management, 42:73-84.

Aneja, K.R., B. Srinvas, and K. Manpreet (1993). Evaluation of Fusarium chlamydosporium as a biocontrol agent of water hyacinth (Eichhornia crassipes) (Mart.) Solms. In: Integrated Weed Management of Sustainable Agriculture: Proceedings of Third Indian Society of Weed Science International Symposium, Hisra, India. Indian Society of Weed Science, Misar, India, pp. 145-149.

Aneja, K.R., and R. Singh (1989). Alternaria alternata (Fr) Keissler, a pathogen of water hyacinth with biocontrol potential. Tropical Pest Management, 35:354-356.

Appelgren, B., W. Klohn, and U. Alam (2000). Water and agriculture in the Nile Basin. FAO, Rome, AGR/MISC/29/2000, 59 pp. 
Auld, B.A. (1997). Bioherbicides. In: Julien, M., and G. White (Eds.), Biological control of weeds: Theory and application. Australian Centre for International Agricultural Research Monograph no. 49, Bruce, ACT, Australia, pp. 129-134.

Aweke, G. (1994). The water hyacinth (Eichhornia crassipes) in Ethiopia. Bulletin des Séances, Académie Royale des Sciences d'Outre-Mer, 39(3):399-404.

Badur-ud-Din, A.A. (1978). Control of aquatic weeds. Second annual report, project No. FG-Pa-271. University of the Punjab, Lahore, Pakistan, 61 pp.

Balciunas, J. (2004). Are mono-specific agents necessarily safe? The need for prerelease assessment of probable impact of candidate biocontrol agents, with some examples. In: Cullen, J.M., D.T. Briese, D.J. Kriticos, W.M. Lonsdale, L. Morin, and J.E. Scott (Eds.), Proceedings of the XI International Symposium on Biological Control of Weeds. CSIRO Publishing, Melbourne, Australia, pp. 252-257.

Barnett, H.L., and B.B. Hunter (1972). Illustrated Genera of Imperfect Fungi. Burgess Publishing Company, Minnesota, $241 \mathrm{pp}$.

Barreto, R.W., and H.C. Evans (1996). Fungal pathogens of some Brazilian aquatic weeds and their potential use in biocontrol. In: Moran, V.C., and J.H. Hoffmann (Eds.), Proceedings of the IX International Symposium on Biological Control of Weeds, Stellenbosch, South Africa. CABI International, Oxford, UK, pp. 121-126.

Barreto, R.W., R. Charudattan, A. Pomella, and R. Hanada (2000). Biological control of neotropical aquatic weeds with fungi. Crop Protection, 19:697-703.

Barrett, S.C.H. (1980). Sexual reproduction in Eichhornia crassipes (water hyacinth). II. Seed production in natural populations. Journal of Applied Ecology, 17:113-124.

Bashir, M.O., Z.E. El Abjar, and N.S. Irving (1984). Observations on the effect of the weevils Neochetina eichhorniae Warner and Neochetina bruchi Hustache on the growth of water hyacinth. Hydrobiologia, 110:95-98.

Bateman, R. (2001). IMPECCA: An international, collaborative program to investigate the development of mycoherbicide for use against water hyacinth in Africa. In: Julien, M.H., M.P. Hill, and D. Jianqing (Eds.), Proceedings of the Second Meeting of the Global Working Group for the Biological and Integrated Control of Water Hyacinth, ACIAR Proceedings 102, pp. 57-61.

Binggeli, P. (2003). Pontederiaceae, Eichhornia crassipes, water hyacinth. In: Goodman, S.M., and J.P. Benstead (Eds.), The Natural History of Madagascar. The University of Chicago Press, Chicago and London, pp. 476-478.

Birch, L.C. (1948). The intrinsic rate of natural increase of an insect population. Journal of Animal Ecology, 17:15-26.

Biswas, S., J. Choudhury, A. Nishat, and M. Rahman (2007). Do invasive plants threaten the Sundarbans mangrove forest of Bangladesh? Forest Ecology Management, 245:1-9. 
Borokoni, T., and F. Babalola (2012). Management of invasive plant species in Nigeria through economic exploitation: Lessons from other countries. Management of Biological Invasions, 3(1):45-55.

Bownes, A., M.P. Hill, and M.J. Byrne (2010a). Assessing density-damage relationships between water hyacinth and its grasshopper herbivore. Entomologia Experimentalis et Applicata, 137:246-254.

Bownes, A., M.P. Hill, and M.J. Byrne (2010b). Evaluating the impact of herbivory by a grasshopper, Cornops aquaticum (Orthoptera: Acrididae), on the competitive performance and biomass accumulation of water hyacinth, Eichhornia crassipes (Pontederiaceae). Biological Control, 53:297-303.

Burrill, L.C., J. Cardenas, and E. Locatelli (1976). Field Manual of Weed Control Research. International Plant Protection Centre, Oregon State University, U.S.A.

Byrne, M.J., M.P. Hill, Robertson, M. King, and A. Jadhav (2010). Integrated Management of E. crassipes in South Africa: Development of an Integrated Management Plan for E. crassipes Control, Combining Biological Control, Herbicidal Control and Nutrient Control, Tailored to the Climatic Regions of South Africa. Water Research Commission Report TT 454-10, Pretoria, South Africa.

CAB International (2015). Data Sheet Type: Invasive species Compendium http://www.Cabi.org/isc/datasheet/20544 (accessed 28 August 2016).

Caesar, A.J. (2003). Synergistic interaction of soilborne plant pathogens and root attacking insects in classical biological control of an exotic rangeland weed. Biological Control, 28:144-153.

Center, T.D. (1985). Leaf life tables: A viable method for assessing sublethal effects of herbivory on water hyacinth shoots. In: Del Foss, E.S. (Ed.), Proceedings of the VI International Symposium on Biological Control of Weeds. Agriculture Canada, Vancouver, Canada, pp. 511-524.

Center, T.D. (1994). Biological control of weeds: Water hyacinth and water lettuce. In: Rosen, D., F.D. Bennett, and J.L. Capinera (Eds.), Pest Management in the Subtropics: Biological Control - A Florida Perspective. Intercept Publishing Company, Andover, United Kingdom, pp. 481-521.

Center, T.D., and W.C. Durden (1986). Variation in water hyacinth/weevil interactions resulting from temporal differences in weed control efforts. Journal of Aquatic Plant Management, 24:28-38.

Center, T.D., and T.K. Van (1989). Alteration of water hyacinth (Eichhornia crassipes (Mart.) Solms) leaf dynamics and phytochemistry by insect damage and plant density. Aquatic Botany, 35:181-195. 
Center, T.D. and F.A. Dray (1992). Associations between water hyacinth weevils (Neochetina eichhorniae and N. bruchi) and phenological stages of Eichhornia crassipes in southern Florida. Florida Entomologist, 75:196-211.

Center, T.D., and M.P. Hill (2002). Field efficacy and predicted host range of the pickerel weed borer, Bellura densa, a potential biological control agent of water hyacinth. BioControl, 47:231-243.

Center, T.D., K.K. Steward, and C.M. Bruner (1982). Control of water hyacinth (Eichhornia crassipes) with Neochetina eichhorniae (Coleoptera: Curculionidae) and a growth retardant. Weed Science, 30:453-457.

Center, T.D., A.F. Cofrancesco, and J.K. Balciunas (1990). Biological control of wetland and aquatic weeds in the southeastern United States. In: Delfosse, E.S. (Ed.), Proceedings of the VII International Symposium on the Biological Control of Weeds, Rome, Italy. Instituto Sperimentale per la Patologia Vegetale, Rome, Italy, pp. 239-262.

Center, T.D., F.A. Dray, G.P. Jubinsky, and A.J. Leslie (1999a). Water hyacinth weevils (Neochetina eichhorniae and N. bruchi) inhibit water hyacinth (Eichhornia crassipes) colony development. Biological Control, 15:39-50.

Center, T.D., F.A. Dray, G.P. Jubinsky, and M.J. Grodowitz (1999b). Biological control of water hyacinth under conditions of maintenance management: Can herbicides and insects be integrated? Environmental Management, 23:241-256.

Center, T.D., M.P. Hill, H. Cordo, and M.H. Julien (2002). Water hyacinth. In: Van Driesche, R.G., S. Lyon, B.B. Lossey, M. Hoddle, and R. Reardon (Eds.). Biological control of invasive plants in the eastern United States. USDA Forest Service, Morgantown, WV, pp. 41-64.

Center, T.D., T.K. Van, F.A. Dray Jr, S.J. Franks, M.T. Rebelo, P.D. Pratt, M.B. Rayamajhi (2005). Herbivory alters competitive interactions between two invasive aquatic plants. Biological Control, 33:173-185.

Center, T.D., F.A. Dray, E.D. Mattison, P.W. Tipping, and M. B. Rayamajhi (2014). Bottom-up effects on top-down regulation of a floating aquatic plant by two weevil species: the context-specific nature of biological control. Journal of Applied Ecology, 51:814-824.

Charudattan, R. (1973). Pathogenicity of fungi and bacteria from India to hydrilla and water hyacinth. Hyacinth Control Journal, 11:44-48.

Charudattan, R. (1990). Biological control by means of fungi. In: Murphy, K.J. and A. Pieterse (Eds.), Aquatic weeds. Oxford Univ. Press, Oxford, UK, pp. 186-201.

Charudattan, R. (1996). Pathogens for biological control of water hyacinth. In: Charudattan, R., R. Labrada, and T.D. Center (Eds.), Strategies for water hyacinth 
control. Food and Agricultural Organization of the United Nations, Rome, Italy, pp. 189-199.

Charudattan, R. (2001a). Biological control of water hyacinth by using pathogens: Opportunities, challenges and recent developments. In: Julien, M.H., M.P. Hill, and D. Jianqing (Eds.), Proceedings of the Second Meeting of the Global Working Group for the Biological and Integrated Control of Water Hyacinth, ACIAR Proceedings 102, pp. 21-28.

Charudattan, R. (2001b). Biological control of weeds by means of plant pathogens: Significance for integrated weed management in modern agro-ecology. Biological Control, 46:229-260.

Charudattan, R. (2005). Ecological, practical, and political inputs into selection of weed targets: What makes a good biological control target? Biological Control, 35:183-196.

Charudattan, R., B.D. Perkins, and R.C. Littell (1978). Effects of fungi and bacteria on the decline of arthropo-damaged water hyacinth (Eichhornia crassipes) in Florida. Weed Science, 26:101-107.

Charudattan, R., S.B. Linda, M. Kluepfel, and Y.A. Osman (1985). Biocontrol efficacy of Cercospora rodmanii on water hyacinth. Phytopathology, 75:1263-1269.

Chaube, H.S., and U.S. Singh (1991). Plant Disease Management, Principles and Practices. CRC Press, 319 pp.

Choo, T., C. Lee, K. Low, and O. Hishamuddin (2006). Accumulation of chromium (VI) from aqueous solutions using water lilies (Nymphaea spontanea). Chemosphere, 62:961-996.

Cilliers, C.J., M.P. Hill, J.A. Ogwang, and O. Ajuonu (2003). Aquatic weeds in Africa and their control. In: Neuenschwander, P., C. Borgemeister, and J. Langewald (Eds), Biological control in IPM systems in Africa. CABI Publishing, Wallingford, UK, pp. 161-178.

Coetzee, J.A., T.D. Center, M.J. Byrne, and M.P. Hill (2005). Impact of the biocontrol agent Eccritotarsus catarinensis, a sap-feeding mirid, on the competitive performance of water hyacinth, Eichhornia crassipes. Biological Control, 32:90-96.

Coetzee, J.A., M.J. Byrne, and M.P. Hill (2007). Predicting the distribution of Eccritotarsus catarinensis, a natural enemy released on water hyacinth in South Africa. Entomologia Experimentalis et Applicata, 125:237-247.

Coetzee, J.A., M.J. Byrne, M.P. Hill, and T.D. Center (2009a). Should the mirid, Eccritotarsus catarinensis (Heteroptera: Miridae), be considered for release against water hyacinth in the United State of America? Biocontrol Science and Technology, 19(1):103-111. 
Coetzee, J.A., M.P. Hill, M.H. Julien, T.D. Center, and H.A. Cordo (2009b). Eichhornia crassipes (Mart.) Solms-Laub. (Pontederiaceae). In: Muniappan, R., G.V.P. Reddy, and A. Raman (Eds.), Biological Control of Tropical weeds using Arthropods, UK: Cambridge University Press, pp. 183-210.

Coetzee, J.A., M.P. Hill, M.J. Byrne, and A. Bownes (2011). A review of the biological control programmes on Eichhornia crassipes (C.Mart.) Solms (Pontederiaceae), Salvinia molesta D.S.Mitch. (Salviniaceae), Pistia stratiotes L. (Araceae), Myriophyllum aquaticum (Vell.) Verdc. (Haloragaceae) and Azolla filiculoides Lam. (Azollaceae) in South Africa. African Entomology, 19(2):451468.

Conlong, D.E., D.Y. Gillespie, K. Drew, E. Khosa, and R. Brudvig (2009). Water weed biocontrol through high stocking rate releases of mass reared insect herbivores. Proceedings of the $82^{\text {nd }}$ South African Sugar Technologist Associations Congress, Durban, South Africa, pp. 18-23.

Conway, K.E. (1976a). Cercospora rodmanii a new pathogen of water hyacinth with biological control potential. Canadian Journal of Botany, 54:1079-1083.

Conway, K.E. (1976b). Evaluation of Cercospora rodmanii as a biological control of water hyacinths. Phytopathology, 66:914-917.

Conway, K.E., and R.E. Cullen (1978). The effect of Cercospora rodmanii, a biological control for water hyacinth, on the fish, Gambush Affins. Mycopathologia, 66(1-2):113-116.

Conway, K.E., T.E. Freeman, and R. Charudattan (1974). The fungal flora of water hyacinth in Florida, part I. Water Resource Center, Gainesville, FL, Publ. No. 30.

Conway, K.E., T.E. Freeman, and R. Charudattan, inventors; Abbott Laboratories, assignee. 27 June 1978. Method and composition for controlling water hyacinth. U.S. patent 4,097,261.

Cordo, H.A. (1999). New agents for biological control of water hyacinth. In: Hill, M.P., M.H. Julien, and T.D. Center (Eds.), Proceedings of the $1^{\text {st }}$ Working Group Meeting for the Biological and Integrated Control of Water Hyacinth, Harare, Zimbabwe, pp. 68-74.

Coyne, D.L., J.M. Nicol, and B. Claudius-Cole (2007). Practical Plant Nematology: A field and Laboratory Guide. SPIPM, IITA, CIMMYT, CTA Research to nourish Africa, Wageningen, The Netherlands, pp. 25-28

Dagno, K., R. Lahlali, M. Diourte, and M.H. Jijakli (2011). Effect of temperature and water activity on spore germination and mycelial growth of three fungal biocontrol agents against water hyacinth (Eichhornia crassipes). Journal of Applied Microbiology, 110:521-528. 
Dagno, K., R. Lahlali, M. Diourte, and J. Haissam (2012). Fungi occurring on water hyacinth (Eichhornia crassipes [Martius] Solms-Laubach) in Niger River in Mali and their evaluation as Mycoherbicides. Journal of Aquatic Plant Management, 50:25-32.

Day, M.D., C.J. Wiley, J. Playford, and M.P. Zaluki (2003). Lantana: current management status and future prospects. ACIAR Monograph Series 102, Canberra, Australia.

De Groote, H., O. Ajuonu, S.S. Attignon, R. Djessou, and P. Neuenschwander (2005). Economic impact of biological control of water hyacinth in Southern Benin. Ecological Economics, 45:105-117.

De Jong, M.D., and W.B. de Voogd, inventors; Biological Farming Systems Group, Wageningen University, assignee. 18 September 2003. Novel mycoherbicides for biological control of aquatic weeds such as water hyacinth and water lettuce. European patent, EPO-DG1 (102).

De Mazancourt, C., and M. Loreau (2000). Grazing optimization, nutrient cycling, and spatial heterogeneity of plant-herbivore interactions: should a palatable plant evolve? Evolution, 54:81-92.

Del Fosse, E.S. (1978). Effect on water hyacinth of Neochetina eichhorniae [Col.: Curculionidae] combined with Orthogalumna terebrantis [Acari: Galumnidae]. Entomophaga, 23(4):379-387.

DellaGreca, M., L. Previtera, and A. Zarrelli (2009). Structures of new phenylphenalene-related compounds from Eichhornia crassipes (water hyacinth). Tetrahedron, 65:8206-8208.

DeLoach, C.J., and H.A. Cordo (1976a). Ecological studies of Neochetina bruchi and $N$. eichhorniae on water hyacinth in Argentina. Journal of Aquatic Plant Management, 14:53-59.

DeLoach, C.J., and H.A. Cordo (1976b). Life cycle and biology of Neochetina bruchi and $N$. eichhorniae. Annals of the Entomological Society of America, 69:643-652.

Denny, P. (1984). Permanent swamp vegetation of the Upper Nile. Hydrobiology, 110:79-90.

Denoth, M., L. Frid, and J.H. Myers (2002). Multiple agents in biological control: improving the odds? Biological Control, 24:20-30.

Ding, J., R. Wang, W. Fu, and G. Zhang (2001). Water hyacinth in China: Its distribution, problems and control status. In: Julien, M.H., M.P. Hill, and D. Jianqing (Eds.), Proceedings of the Second Meeting of the Global Working Group for the Biological and Integrated Control of Water Hyacinth, ACIAR Proceedings 102, pp. 29-32. 
Ding, Y., N. Zhao, and J.J. Chu (2008). Nine pathogenic fungi of water hyacinth isolated in China. Journal of Shanghai Jiaotong University, 13(5):617-622.

Dula, A., T. Taye, and Y. Firehun (2008). Efficacy of integrated water hyacinth (Eichhornia crassipes [Mart.] Solms) management strategies at Wonji-Shoa sugar factory. Ethiopian Journal of Weed Management, 2:45-58.

Eckenwalder, J.E, and S.C.H. Barrett (1986). Phylogenetic systematics of Pontederiaceae. Systematic Botany, 11:373-391.

Edwards, D., and C.J. Musil (1975). Eichhornia crassipes in South Africa - a general review. Journal of Limnological Society of Southern Africa, 1:23-27.

EEA (2012). The impacts of invasive alien species in Europe. EEA Technical report No. 16/2012. Luxembourg: Publications Office of the European Union, 2012. http://www.eea.europa.eu/publications/impacts-of-invasivealien-species (accessed 12 August 2016).

EIAR/UNEP-GEF (2009). Removing Barriers in Invasive Plant Management in Africa. Global Environmental Facility (GEF) Interim evaluation report. EIAR, Addis Ababa.

El Abjar, Z.E., and M.O. Bashir (1984). Biology and life-tables of Neochetina bruchi Hustache (Coleoptera, Curculionidae) introduced to the White Nile, Sudan for the biological control of water hyacinth. Zeitschrift fur Angewandte Entomologie, 97:282-286.

El-Morsy, E.M. (2004). Evaluation of microfungi for the biological control of water hyacinth in Egypt. Fungal Diversity, 16:35-51.

El-Morsy, E.M., S.M. El-Dohlob, and K.D. Hyde (2006). Diversity of Alternaria alternata a common destructive pathogen of Eichhornia crassipes in Egypt and its potential use in biological control. Fungal Diversity, 23:139-158.

Elwakil, M.A., E.A. Sadik, E.A. Fayzaka, and Y.M Shabana (1990). Biological control of water hyacinth with fungal pathogens in Egypt. In: Delfosse E.S and R.R. Scoot (Eds.), Proceedings of the VIII International Symposium on the Biological Control of Weeds. Lincoln University, Canterbury, New Zealand, pp. 483-497.

Ethiopian Agricultural Research Organization (EARO) (2003). Removing Barriers in Invasive Plant Management in Africa. Global Environmental Facility (GEF) Proposal for PDF B Block Grant. EARO, Addis Ababa.

Evans, F.C., and F.E. Smith (1952). The intrinsic rate of natural increase for a human louse, Pediculus humanus L. American Natural, 830:299-310.

Evans, H.C., and R.H. Reeder (2001). Fungi associated with Eichhornia crassipes (water hyacinth) in the upper Amazon basin and prospects for their use in biological control. In: Julien, M.H., M.P. Hill, T.D. Center, and D. Jianqing (Eds.), 
Proceedings of the Second Meeting of the Global Working Group for the Biological and Integrated Control of Water Hyacinth, ACIAR Proceedings 102, pp. 62-70.

Fasil, R. (2004). A review of Striga management in Eastern Africa. Pest Management Journal of Ethiopia, 8:1-12.

Fernandez, O.A., D.L. Sutton, V.H. Lallana, M.R. Sabbatini, and J.H. Irigoyan (1990). Aquatic weed problems and management in South and Central America. In: Charudattan, R. (Ed.), Aquatic Weeds - the Ecology and Management of Nuisance Aquatic Vegetation. Oxford University Press, New York, pp. 406-425.

Firehun, Y., and Z. Yohannes (2009). Evaluation of some herbicides against water hyacinth (Eichhornia crassipes [Mart.] Solms) at Wonji-Shoa. Proceedings of Ethiopian Sugar Industry Biennial Conference, 1:61-68.

Firehun, Y., T. Abera, G. Tariku, and T. Taye (2007). Distribution, impact and management of water hyacinth at Wonji-Shoa sugar factory. Ethiopian Journal of Weed Management, 1:41-52.

Firehun, Y., P.C. Struik, E.A. Lantinga, and T. Taye (2013). Joint use of insects and fungal pathogens in the management of water hyacinth (Eichhornia crassipes): Perspectives for Ethiopia. Journal of Aquatic Plant Management, 51:109-121.

Firehun, Y., P.C. Struik, E.A. Lantinga, and T. Taye (2014). Water hyacinth in the Rift Valley water bodies of Ethiopia: Its distribution, socio-economic importance and management. International Journal of Current Agriculture Research, 3:67-75.

Firehun, Y., P.C. Struik, E.A. Lantinga, and T. Taye (2015). Adaptability of two insects (Neochetina bruchi and Neochetina eichhorniae) with potential to control water hyacinth in the Rift Valley of Ethiopia. Crop Protection, 76:75-81.

Firehun, Y., P.C. Struik, E.A. Lantinga, and T. Taye (2016). Pre-release evaluation of Neochetina weevils potential for the management of Eichhornia crassipes [Mart.] Solms in the Rift Valley of Ethiopia. Academia Journal of Agricultural Research, 4(7):394-403.

Firehun, Y., P.C. Struik, E.A. Lantinga, and T. Taye (2017). Occurrence and diversity of fungal pathogens associated with water hyacinth and their potential as biocontrol agents in the Rift Valley of Ethiopia. International Journal of Pest Management (published online 11 Jan 2017).

Forno, I.W. (1981). Effects of Neochetina eichhorniae on the growth of water hyacinth. Journal of Aquatic Plant Management, 19:27-31.

Freeman, T.E., and R. Charudattan (1984). Cercospora rodmanii Conway, a potential biocontrol agent. Gainesville, Florida Agricultural Experiment Station Technical Bulletin, 842:18. 
Galbraith, J.C. (1987). The pathogenicity of an Australian isolate of Acremonium zonatum to water hyacinth, and its relationship with the biological control agent, Neochetina eichhorniae. Australian Journal of Agricultural Research, 38:219-229.

Galbraith, J.C., and A.C. Hayward (1984). The potential of indigenous microorganisms in the biological control of water hyacinth in Australia. Australian Water Resources Council, Canberra, ACT, Australia, AWRC Research Project 80/132.

Getachew, A. (1997). Flora of Ethiopia and Eritrea. In: Edwards, S., S. Demissew, and I. Hedberg (Eds.), Vol. 6, Hydrocharytaceae to Arecaceae. Addis Ababa, Ethiopia, Uppsala, Sweden, pp. 308-310.

Gichuki, J., R. Omondi, P. Boera, T.T. Okorut, A.S. Matano, T. Jembe, and A. Ofulla (2012). Water hyacinth Eichhornia crassipes (Mart.) Solms-Laubach dynamics and succession in the Nyanza Gulf of Lake Victoria (East Africa): Implications for water quality and biodiversity conservation. The Scientific World Journal, 1-10.

Gopal, B. (1987). Aquatic Plant Studies 1. Water Hyacinth. Elsevier Publishing, New York.

Graham, S.W., R.G. Olmstead, and S.C.H. Barret (2002). Rooting phylogenetic trees with distant out-groups. A case study from Commelinoid Monocots. Molecular Biology and Evolution, 19:1769-1781.

Grodowitz, M.J., R.M. Stewart, and A.F. Cofrancesco (1991). Population dynamics of water hyacinth and the biological control agent Neochetina eichhorniae (Coleoptera: Curculionidae) at a southeast Texas location. Environmental Entomology, 20:652-660.

Grodowitz, M.J., J.E. Freedman, H. Jones, L. Jeffers, C.F. Lopez, and F. Nibling (2000). Status of water hyacinth/hydrilla infestations and associated biological control agents in Lower Rio Grande Valley cooperating irrigation districts. Technical Report ERDC/EL SR-00-11. U.S. Army Corps of Engineers Washington, DC.

Hailu, S., T. Demel, N. Sileshi, and A. Fassil (2004). Some biological characteristics that foster the invasion of Prosopis juliflora (Sw.) DC. at Middle Awash Rift Valley, North-Eastern Ethiopia. Journal of Arid Environment, 58:135-154.

Harley, K.L.S. (1990). The role of biological control in the management of water hyacinth, Eichhornia crassipes. Biocontrol News and Information, 11:11-22.

Harley, K.L.S., and I.W. Forno (1992). Biological control of weeds a handbook for practitioners and students. Inkata Press, Melbourne, $74 \mathrm{pp}$.

Harley, K.L.S., M.H. Julien, and A.D. Wright (1996). Water hyacinth: A tropical worldwide problem and methods for its control. In: Brown, H., G.W. Cussans, M.D. Devine, S.O. Duke, C. Fernandez-Quintanilla, A. Helweg, R.E. Labrada, M. 
Landes, P. Kudsk, and J.C. Streibig (Eds.), Proceedings of $2^{\text {nd }}$ International Weed Control Congress II, Copenhagen, Denmark, pp. 639-644.

Hatcher, P.E. (1995). Three-way interactions between plant pathogenic fungi, herbivorous insects and their host plants. Biological Reviews, 70:639-694.

Heard, T.A., and S.L. Winterton (2000). Interactions between nutrient status and weevil herbivory in the biological control of water hyacinth. Journal of Applied Ecology, 37:117-127.

Heath, R.N., J. Roux, B. Slippers, A. Drenth, S.R. Pennycook, B.D. Wingfield, and M.J. Wingfield (2011). Occurrence and pathogenicity of Neofusicoccum parvum and N. mangiferae on ornamental Tibouchina species. Forest Pathology, 41:48-51.

Hernandez, M.C. (2008). Biology of Thrypticus truncatus and Thrypticus sagittatus (Diptera: Dolichopodidae), petiole miners of water hyacinth, in Argentina, with morphological descriptions of larvae and pupae. Annals of the Entomological Society of America, 101(6):1041-1049.

Hernandez, M.C., M.B. Pildain, M.V. Novas, J. Sacco, and S.E. Lopez (2007). Mycobiota associated with larval mines of Thrypticus truncates and T. sagittatus (Diptera, Dolichopodidae) on water hyacinth, Eichhornia crassipes, in Argentina. Biological Control, 41:321-326.

Hettiarachchi, S., S.A. Gunasekera, and I. Balasooriya (1983). Leaf spot diseases of water hyacinth in Sir Lanka. Journal of Aquatic Plant Management, 21:62-65.

Hill, M. (1999). The world's worst aquatic weed. Pesticide Outlook: 58-61.

Hill, M.P., and T. Olckers (2001). Biological control initiatives against water hyacinth in South Africa: Constraining factors, success and new courses of action. In: Julien, M.H., M.P. Hill, and D. Jianqing (Eds.), Proceedings of the Second Meeting of the Global Working Group for the Biological and Integrated Control of Water Hyacinth, ACIAR Proceedings 102, pp. 33-38.

Hill, M.P., and J.A. Coetzee (2008). Integrated control of water hyacinth in Africa. EPPO Bulletin, 38:452-457.

Hill, M.P., C.J. Cilliers and S. Neser (1999). Life history and laboratory host range of Eccritotarsus catarinensis (Carvalho) (Heteroptera: Miridae), anew natural enemy released on water hyacinth (Eichhornia crassipes (Mart.) Solms Laub) (Pontederiaceae) in South Africa. Biological Control, 14:127-133.

Holm, L.G., D.L. Plucknett, J.V. Pancho, and J.P. Herberger (1977). The World's Worst Weeds: Distribution and Biology. University Press, Honolulu, Hawaii.

Holm, L.G., D.L. Plucknett, J.V. Pancho, and J.P. Herberger (1991). The World's Worst Weeds: Distribution and Biology. Melbourne, FL: Krieger Publishing Company. 
Howard, G.W., and S.W. Matindi (2003). Alien Invasive Species in Africa's Wetlands. Some threats and solutions. IUCN Eastern African Regional Program, Nairobi, Kenya.

Howe, R.W. (1953). The rapid determination of the intrinsic rate of increase of an insect population. Annals of Applied Biology, 40:134-151.

Impson, F.A.C., V.C. Moran, C. Kleinjan, J.H. Hoffmann, and J.A. Moore (2008). Multiple-species introductions of biological control agents against weeds: Look before you leap. XII International Symposium on Biological Control of Weeds, CABI.

Jamil, K., and D. Rajagopal (1986). Studies on the mycoflora of water hyacinth: Their individual and combined effect on the phyllosphere. Indian Journal of Microbiology, 26:70-77.

Jayanth, K.P. (1988). Successful biological control of water hyacinth (Eichhornia crassipes) by Neochetina eichhorniae (Coleoptera: Curculionidae) in Bangalore. Indian Journal of Tropical Pest Management, 34:263-266.

Jones, R. (2009). The impact on biodiversity, and integrated control, of water hyacinth, Eichhornia crassipes (Martius) Solms-Laubach (Pontederiaceae) on the Lake Nsezi - Nseleni River System. MSc Thesis. Department of Zoology and EntomologyRhodes University. South Africa, 115 pp.

Julien, M.H. (2001). Biological control of water hyacinth with arthropods: a review to 2000. Biological and integrated control of water hyacinth Eichhornia crassipes. In: Julien, M.H., M.P. Hill, and D. Jianqing (Eds.), Proceedings of the Second Meeting of the Global Working Group for the Biological and Integrated Control of Water Hyacinth, ACIAR Proceedings 102, pp. 8-20.

Julien, M.H., and M.W. Griffiths (1998). Biological control of weeds: A world catalogue of agents and their target weeds. $4^{\text {th }}$ edition, CABI, Wallingford, UK.

Julien, M.H., and W. Orapa (1999). Structure and management of a successful biological control project for water hyacinth. In: Hill, M.P., M.H. Julien, and T.D. Center (Eds.), Proc. of the First Global Working Group Meeting for the Biological and Integrated Control of Water hyacinth, Harare, Zimbabwe, pp. 123-134.

Julien, M.H., K.L.S. Harley, A.D. Wright, C.J. Cilliers, M.P. Hill, T.D. Center, H.A. Cordo, and A.F. Cofrancesco (1996). International co-operation and linkages in the management of water hyacinth with emphasis on biological control. In: Moran, V.C., and J.H. Hoffmann (Eds.), Proceedings of IX International Symposium Biological Control of Weeds, University of Cape Town, Stellenbosch, South Africa, pp. 273-282.

Julien, M.H., M.W. Griffiths, and A.D. Wright (1999). Biological control of water hyacinth. The weevils Neochetina bruchi and Neochetina eichhorniae: biologies, 
host ranges, and rearing, releasing and monitoring techniques for biological control of Eichhornia crassipes. ACIAR Monograph No. 60, 87 pp.

Julien, M.H., M.W. Griffiths, and J.N. Stanley (2001). Biological control of water hyacinth. The moths Niphograpta albiguttalis and Xubida infusellus: Biologies, host ranges, and rearing, releasing and monitoring techniques. ACIAR Monograph, Series 79, $91 \mathrm{pp}$.

Kassahun, Z., L. Yohannes, and N. Olani (2004). Prosopis juliflora: Potentials and Problems. Arem, 6: 1-10.

Kateregga, E. and T. Sterner (2009). Lake Victoria fish stocks and the effects of water hyacinth. The Journal of Environment and Development, 18:62-78.

Kateregga, E., and T. Sterner (2007). Indicators for an invasive species: Water hyacinths in Lake Victoria. Ecological Indicators, 7:362-370.

Kelch, D.G., and A. McClay (2004). Putting the phylogeny into the centrifugal phylogenetic method. In: Cullen, J.M., D.T. Briese, D.J. Kriticos, W.M. Lonsdale, L. Morin, and J.K. Scott (Eds.), Proceedings of the XI International Symposium on Biological Control of Weeds. CSIRO Entomology, Canberra, Australia, pp. 287296.

Kumar, S., and N. Rohatgi (1999). The role of invasive weeds in changing floristic diversity. Annals of Forestry, 71(1):147-150.

Leslie, P.H., and T. Park (1949). The intrinsic rate of natural increase of Tribolium castameum Herbst. Ecology, 30:469-477.

Lindsey, K., and H.M. Hirt (1999). Use Water Hyacinth: A Practical Handbook of Uses for the Water Hyacinth from Across the World. Winnenden, Germany.

Mailu, A.M. (2001). Preliminary assessment of the social, economic and environmental impacts of water hyacinth in the Lake Victoria basin and the status of control. In: Julien, M.H., M.P. Hill, and D. Jianqing (Eds.), Proceedings of the Second Meeting of the Global Working Group for the Biological and Integrated Control of Water Hyacinth, ACIAR Proceedings 102, pp. 130-139.

Malik, A. (2007). Environmental challenge vis a vis opportunity: The case of water hyacinth. Environment International, 33: 122-138.

Mallya, G., P. Mjema, and J. Ndunguru (2001). Water hyacinth control through integrated weed management strategies in Tanzania. In: Julien, M.H., M.P. Hill, and D. Jianqing (Eds.), Proceedings of the Second Meeting of the Global Working Group for the Biological and Integrated Control of Water Hyacinth, ACIAR Proceedings 102, pp. 120-122.

Mangoendihardjo, S., O. Setyawati, R.A. Syed, and S. Sosromarsono (1978). Insects and fungi associated with some aquatic weeds in Indonesia. In: Proceedings of the 
$6^{\text {th }}$ Asian-Pacific Weed Science Society Conference, Jakarta, Indonesia. AsianPacific Weed Science Society, St. Lucia, QLD, Australia, pp. 440-446.

Martinez, J.M., and R. Charudattan (1998). Survey and evaluation of Mexican native fungi for potential biocontrol of water hyacinth. Journal of Aquatic Plant Management, 36:145-148.

Martinez, J.M., and E.L. Gutierrez (2001). Host range of Cercospora piaropi and Acremonium zonatum, potential fungal biocontrol agents for water hyacinth in Mexico. Phytoparasitica, 29(2):175-177.

Martinez, J.M., and M.A. Gomez Balandra (2007). Integrated control of Eichhornia crassipes by using insects and plant pathogens in Mexico. Crop Protection, 26:1234-1238.

Martinez, J.M., E.L. Gutierrez, R.D. Huerto, and E.R. Franco (2001). Importation, rearing, release and establishment of Neochetina bruchi (Coleoptera: Curculionidae) for the biological control of water hyacinth in Mexico. Journal of Aquatic Plant Management, 39:140-143.

Masifwa, W.F., T. Twongo, and P. Denny (2001). The impact of water hyacinth, Eichhornia crassipes (Mart.) Solms, on the abundance and diversity of aquatic macroinvertebrates along the shores of northern Lake Victoria, Uganda. Hydrobiology, 452:79-88.

Mbati, G., and P. Neuenschwander (2005). Biological control of three floating water weeds, Eichhornia crassipes, Pista stratotes, and Salvinia molesta in the Republic of Congo. Biocontrol, 50:635-645.

McClay, A.S., and J.K. Balciunas (2005). The role of pre-release efficacy assessment in selecting classical biological control agents for weeds: Applying the Anna Karenina principle. Biological Control, 35:197-207.

Meyer, G.A. (1998). Mechanisms promoting recovery from defoliation in goldenrod (Solidago altissima). Canadian Journal of Botany, 76:450-459.

Midgley, J.M., M.P. Hill, and M.H. Villet (2006). The effect of water hyacinth, Eichhornia crassipes (Martius) Solms-Laubach (Pontederiaceae), on benthic biodiversity in two impoundments on the New Year's River, South Africa. African Journal of Aquatic Science, 31(1):25-30.

Milbrath, L.R., and J.R. Nechols (2004). Individual and combined effects of Trichosirocalus horridus and Rhinocyllus conicus (Coleoptera: Curculionidae) on musk thistle. Biological Control, 30:418-429.

Mitchell, D.S. (1985). African aquatic weeds and their management. In: Denny, P. (Ed.), The ecology and management of African Wetland Vegetation. Dr. W. Junk Publishers, pp. 177-202. 
Mohan Babu, R., A. Sajeena, K. Seetharaman, P. Vidhyasekeran, P. Rangasamy, M. Som Prakash, A.K. Senthil Raja, and R. Biji (2002). Host range of Alternaria alternata - a potential fungal biocontrol agent for water hyacinth in India. Crop Protection, 21:1083-1085.

Mohan Babu, R., A. Sajeena, and K. Seertharaman (2003). Bioassay of the potentiality of Alternaria alternata (Fr.) Keissler as a bioherbicide to control water hyacinth and other aquatic weeds. Crop Protection, 22:1005-1013.

Moran, P.J. (2004). Plant mediated interactions between Neochetina spp. weevils and the fungal pathogen Cercospora piaropi on water hyacinth (Eichhornia crassipes). In: Cullen, J.M., D.T. Briese, D.J. Kriticos, W.M. Lonsdale, L. Morian and J.K. Scott (Eds.), Proceedings of the XI International Symposium on Biological Control of Weeds. CSIRO Entomology, Canberra, Australia, pp. 430-435.

Moran, P.J. (2005). Leaf scarring by the weevils Neochetina eichhorniae and $N$. bruchi enhances infection by the fungus Cercospora piaropi on water hyacinth, Eichhornia crassipes. BioControl, 50:511-524.

Moran, P.J. (2006). Water nutrients, plant nutrients, and indicators of biological control on water hyacinth at Texas field sites. Journal of Aquatic Plant Management, 44:109-114.

Moran, P.J., and C.J. Graham (2005). Vectoring of plant pathogenic fungi by water hyacinth weevils (Neochetina spp.) and biological control of water hyacinth. USDA-Agricultural Research Service, Beneficial Insects Research Unit, Weslaco, Texas.

Moran, P.J., M.J. Pitcairn and B. Villegas (2016). First establishment of the planthopper, Megamelus scutellaris Berg, 1883 (Hemiptera: Delphacidae), released for biological control of water hyacinth in California. Pan-Pacific Entomologist, 92(1):32-43.

Morris, M.J., A.R. Wood, and A. den Breey (1999). Plant pathogens and biological control of weeds in South Africa: A review of projects and progress during the last decade. In: Olckers T., and M. P. Hill (Eds.), African Entomology Memoir 1. Entomological Society of South Africa, Hatfield, South Africa, pp. 129-137.

Mujingni, C. (2012). Quantification of the impacts of water hyacinth on riparian communities in Cameroon and assessment of an appropriate method of control: The case of the River Wouri Basin. MSc dissertation. World Maritime University, Malmö, Sweden.

Munsell soil color charts (1994). Munsell color. Macbeth Division of Kollmorgen Instruments Corporation, New Windsor, Britain.

MWBP/RSCP (2006). Invasive Alien Species in the Lower Mekong Basin: Current State of Play. Mekong Wetland Biodiversity Programme and Regional Species 
Conservation Programme, The World Conservation Union (IUCN), Asia, Sri Lanka, 22 pp.

Nag Raj, T.R., and K.M. Ponnappa (1970). Blight of water hyacinth caused by Alternaria eichhorniae sp. nov. Transactions of the British Mycological Society, 55:123-130.

Naseema, A., R. Praveena, S. Balakrishnan, and C.K. Peethambaran (2001). Management of water hyacinth [Eichhornia crassipes (Mart.) Solms] with fungal pathogens. The British Crop Protection Council Conference, Weeds, 1:263-268.

Navarro, L., and G. Phiri (2000). Water hyacinth in Africa and the Middle East. A survey of problems and solutions. International Development Research Centre, Ottawa (CA), 140 pp.

Ndimele, P., C. Kumolu-Johnson, and M. Anetekhai (2011). The invasive aquatic macrophyte, water hyacinth [Eichhornia crassipes (Mart.) Solm-Laubach: Pontedericeae]: problems and prospects. Research Journal of Environmental Science, 5:509-520.

Nijoka, S.W. (2001). The Biology and Impact of Neochetina Weevils on Water Hyacinth, Eichhornia crassipes in Lake Victoria Basin, Kenya. PhD Dissertation Paper, Moi University, Kenya, Nairobi, 167 pp.

Ochiel, G.S., S.W. Njoka, A.M. Mailu, and W. Gitonga (2001). Establishment spread and impact of Neochetina spp. on water hyacinth in Lake Victoria, Kenya. In: Julien, M.H., M.P. Hill, and D. Jianqing (Eds.), Proceedings of the Second Meeting of the Global Working Group for the Biological and Integrated Control of Water Hyacinth, ACIAR Proceedings 102, pp. 89-95.

Ogwang, J.A., and R. Molo (1997). Biological control of water hyacinth in Uganda. Proceedings of the $16^{\text {th }}$ Weed Science Society of East Africa Conf., pp. 287-293.

Ogwang, J.A., and R. Molo (1999). Impact studies on Neochetina bruchi and Neochetina eichhorniae in Lake Kyoga, Uganda. In: Hill, M.P., M.H. Julien and T.D. Center (Eds.), Proceedings of the $1^{\text {st }}$ Working Group Meeting for the Biological and Integrated Control of Water Hyacinth, Harare, Zimbabwe, pp. 10-13.

Ogwang, J.A., and R. Molo (2004). Threat of water hyacinth resurgence after a successful biological control. Biocontrol Science and Technology, 14(6):623-626.

Okunowo, W.O., G.O. Gbenle, A.A. Osuntoki, and A.A. Adekunle (2008). Survey, evaluation and molecular characterization of Nigerian native fungus for potential biocontrol of water hyacinth. Phytopathology, 98:S115.

Patel, S. (2012). Threats, management and envisaged utilizations of aquatic weed Eichhornia crassipes: An overview. Reviews in Environmental Science and Biotechnology, 11(3):249-259. 
Pavlic, D., B. Slippers, T.A. Coutinho, and M.J. Wingfield (2007). Botryosphaeriaceae occurring on native Syzygium cordatum in South Africa and their potential threat to Eucalyptus. Plant Pathology, 56:624-636.

Pennington, J.C., and E.A. Theriot (1983). Compatibility and infectivity of a Cercospora rodmanii formulation with enhancing agents. U.S. Army Engineer Waterways Experiment Station, Vicksburg, MS, Paper A-83-6.

Perkins, B.D. (1974). Arthropods that stress water hyacinth. PANS Pest Article News and Summaries, 20(3):304-314.

Perkins, B.D. (1978). Enhancement of effect of Neochetina eichhorniae for biological control of water hyacinth. In: Freeman, T.E. (Ed.), Proce. of the Fourth International Conference on Biological Control of Weeds, Gainesville, FL, pp. 87-92.

Phillip, M.C. (1992). A survey of the arable weeds of Botswana. Tropical Pest Management, 38(1):13-21.

Praveena, R., and A. Naseema (2004). Fungi occurring on water hyacinth [Eichhornia crassipes (Mart.) Solms] in Kerala. Journal of Tropical Agriculture, 42(1-2):21-23.

Rakvidhyasastra, V., M. Iemwimangsa, and V. Petcharat (1978). Host range of fungi pathogenic to water hyacinth (Eichhornia crassipes [Mart.] Solms). Kasetsart Journal-Natural Science, 12:114-118.

Rao, V.S. (1988). Principles of weeds science. $3^{\text {rd }}$ edition, Oxford and IBH Publishing Co. Pvt. Ltd., New Delhi.

Ray, P. (2006). Management of water hyacinth employing some insects and fungi. $\mathrm{PhD}$ Thesis, R.D. University, Jabalpur, India.

Rebka, G. (2006). Survey of Pathogenic Fungi on Striga in North Shewa, Ethiopia and Assessment for Their Biocontrol Potential. MSc Thesis. Haramaya University, Haramaya, Ethiopia, 65 pp.

Reddy, K.R., M. Agami, and J.C. Tucker (1990). Influence of phosphorus on growth and nutrient storage by water hyacinth (Eichhornia crassipes (Mart.) Solms) plants. Aquatic Botany, 37:355-365.

Reddy, K.R., M. Agami, E.M. D’Angeleo, and J.C. Tucker (1991). Influence of potassium supply on growth and nutrient storage by water hyacinth. Bioresource Technology, 37: 79-84.

Rezene, F. (2005). Water hyacinth (Eichhornia crassipes): A review of its weed status in Ethiopia. Arem, 6:105-111.

Rezene, F. (2012). Status of water hyacinth (Eichhornia crassipes) in Ethiopia: Challenges and response. In: Berihun Tefera, Workiye Worie and Melaku Wale (Eds.). Proceedings of the Second National Workshop on Challenges and Opportunities of Water Resources Management in Tana Basin, Upper Blue Nile 
Basin, Ethiopia, 26-27 March 2012. Blue Nile Water Institute - Bahir Dar University (BNWI-BDU), Bahir Dar, Ethiopia, pp. 159-166.

Rhomela, F., M. Masangkay, O. Mabbayad, C.P. Timothy, and K.W. Alan (1999). Host range of Alternaria alternata causing leaf blight of Sphenoclea zeylanica. Candian Journal of Botany, 77:103-112.

Rzoska, J. (1974).The Upper Nile swamps, a tropical wetland study. Freshwater Biology, 4:1-30.

Sanders, D.R., and E.A. Theriot (1986). Large-scale operations management test (LSOMT) of insects and pathogens for control of water hyacinth in Louisiana, Volume II: Results for 1982-1983. U.S. Army Engineer Research and Development Center Aquatic Plant Control Research Program Technical Report, A-85-1, Vicksburg, M.S.

SAS Institute (2008). SAS Version 9.1, 2008C 2007-2008. SAS Institute, Inc., Cary, NC.

Schooler, S.S., and P.B. McEvoy (2006). Relationship between insect density and plant damage for the golden loosestrife beetle, Galerucella pusilla, on purple loosestrife (Lythrum salicaria). Biological Control, 36:100-105.

Senayit, R., T. Agajie, T. Taye, W. Adefires, and E. Getu (2004). Invasive Alien Plant Control and Prevention in Ethiopia. Pilot Surveys and Control Baseline Conditions. Report submitted to EARO, Ethiopia and CABI under the PDF B phase of the UNEP GEF Project - Removing Barriers to Invasive Plant Management in Africa. EARO, Addis Ababa, Ethiopia.

Shabana, Y.M. (1997). Vegetable oil suspension emulsions for formulating a weed pathogen to bypass dew. Journal of Plant Disease Protection, 104:239-245.

Shabana, Y.M. (2002). Water hyacinth in Egypt: Its problems and strategies for its control with a special reference to the biological control as a safe, non-polluting management approach. In: Proceedings of the Second Conference on Food-borne Contamination and Egyptians' Health. Mansoura University, El-Mansoura, Egypt, pp. 11-43.

Shabana, Y.M. (2005). The use of oil emulsions for improving the efficacy of Alternaria eichhorniae as a mycoherbicide for water hyacinth (Eichhornia crassipes). Biological Control, 32:78-89.

Shabana, Y.M., R. Charudattan, and M.A. Elwakil (1995a). Identification, pathogenicity, and safety of Alternaria eichhorniae from Egypt as a bioherbicide agent for water hyacinth. Biological Control, 5:123-135.

Shabana, Y.M., R. Charudattan, and M.A. Elwakil (1995b). Evaluation of Alternaria eichhorniae as a bioherbicide for water hyacinth (Eichhornia crassipes) in greenhouse trials. Biological Control, 5:136-144. 
Shabana, Y.M., Z.A.M. Baka, and G.M. Abdel-Fattah (1997). Alternaria eichhorniae, a biological control agent for water hyacinth: Mycoherbicidal formulation and physiological and ultrastructural host responses. European Journal of Plant Pathology, 103:99-111.

Shabana, Y.M., M.A. Elwakil, and R. Charudattan (2000). Effect of media, light and $\mathrm{pH}$ on growth and spore production by Alternaria eichhorniae, a mycoherbicide agent for water hyacinth. Journal of Plant Disease Protection, 107:617-626.

Shabana, Y.M., M.A. Elwakil, and R. Charudattan (2001a). Biological control of water hyacinth by mycoherbicide in Egypt. In: Julien, M.H., M.P. Hill, and D. Jianqing (Eds.), Proceedings of the Second Meeting of the Global Working Group for the Biological and Integrated Control of Water Hyacinth, ACIAR Proceedings 102, pp. 53-56.

Shabana, Y.M., M.A. Elwakil, and R. Charudattan (2001b). Effect of nutrition and physical factors on mycelial growth and production of pigments and non chromatic UV-absorbing compounds of Alternaria eichhorniae. Journal of Phytopathology, 149:21-27.

Sosa, A.J., R. Marino, A.M. Lenicov, R. Mariani, and H.A. Cordo (2004). Redescription of Megamelus scutellaris Berg (Hemiptera: Delphacidae), a candidate for biological control of water hyacinth. Annual Entomology Society of America, 97:271-275.

Sosa, A.J., R. Marino, A.M. Lenicov, R. Mariani, and H.A. Cordo (2005). Life history of Megamelus scutellaris with description of immature stages (Hemiptera: Delphacidae). Annals of the Entomological Society of America, 98:66-72.

Sosa, A.J., H.A. Cordo, and J. Sacco (2007a). Preliminary evaluation of Megamelus scutellaris Berg (Hemiptera: Delphacidae), a candidate for biological control of water hyacinth. Biological Control, 42:129-138.

Sosa, A.J., R. Marino, A.M. Lenicov, and R. Mariani (2007b). Species of Megamelus (Hemiptera: Delphacidae) associated with Pontederiaceae in South America. Annual Entomology Society of America, 100:798-809.

Stanley, J.N., and M.H. Julien (1999). The host range of Eccritotarsus catarinensis (Heteroptera: Miridae), a potential agent for the biological control of water hyacinth (Eichhornia crassipes). Biological Control, 14:134-140.

Stanley, J.N., M.H. Julien, and T.D. Center (2007). Performance and impact of the biological control agent Xubida infusella (Lepidoptera: Pyralidae) on the target weed Eichhornia crassipes (water hyacinth) and on a nontarget plant, Pontederia cordata (pickerelweed) in two nutrient regimes. Biological Control, 40:298-305. 
Stark, J.D., and R.A. Goyer (1983). Life cycle and behavior of Neochetina eichhorniae Warner (Coleoptera: Curculionidae) in Louisiana: A biological control agent of water hyacinth. Environmental Entomology, 12(1):147-150.

Stroud, A. (1994). Water hyacinth (Eichhornia crassipes [Mart.] Solms) in Ethiopia. In: Rezene, F. (Ed.), Proceedings of the $9^{\text {th }}$ Annual Conference of Ethiopian Weed Science Committee, Addis Ababa, Ethiopia, pp. 7-16.

Sutherst, R.W., G.F. Maywald, and B.L. Russell (2000). Estimating vulnerability under global change: Modular modelling of pests. Agriculture Ecosystem and Environment, 82:303-319.

Sutherst, R.W., G.E. Maywald, W. Bottomley, and A. Bourne (2004). CLIMEX v2. Hearne Scientific Software, Melbourne, Australia.

Syrett, P., D.T. Briese, and J.H. Hoffmann (2000). Success in biological control of terrestrial weeds by arthropods. In: Gurr, G., and S. Wratten (Eds.), Biological Control: Measures of Success. Kluwer Academic Publishers, Dordrecht, The Netherlands, pp. 189-230.

Taye, T., G. Einhorn, M. Gossmann, C. Buttner, and R. Metz (2004a). The potential of parthenium rust as biological control of parthenium weed in Ethiopia. Pest Management Journal of Ethiopia, 8:83-95.

Taye, T., C. Obermeier, G. Einhorn, E. Seemuller, and C. Buttner (2004b). Phyllody disease of parthenium weed in Ethiopia. Pest Management Journal of Ethiopia, 8:39-50.

Taye, T., F. Rezene, Y. Firehun, T. Derje, and T. Tamado (2009). Review invasive weed research in Ethiopia. In: Abraham, T. (Ed.), Increasing crop production through improved plant protection: Vol. 2. Plant Protection Society of Ethiopia, Addis Ababa, Ethiopia, pp. 381-407.

Tegene, S., and N. Ayele (2014). Prevalence and intensity of water hyacinth infestation in the water bodies of Rift Valley, Ethiopia. The Journal of Agriculture and Natural Resources Science, 1(2):118-126.

Tenalem, A. (2004). Environmental implications of changes in the levels of lakes in the Ethiopian Rift since 1970. Regional Environmental Change, 4:192-204.

Ter Braak, C.J.F. (2003). Program CANOCO Version 4.5A (1988-2003), Biometris quantitative methods in the life and earth sciences. Plant Research International, Wageningen University and Research Centre, Wageningen, The Netherlands.

Ter Braak, C.J.F., and I.C. Prentice (1988). A theory of gradient analysis. Advances in Ecological Research, 18:271-317.

Terry, P.J. (1996). The water hyacinth problem in Malawi and foreseen methods of control. Strategies for Water Hyacinth Control. Report of a panel of experts meeting, 1995, Fort Lauderdale, USA. FAO, Rome, Italy, pp. 59-81. 
Tessmann, D.J., R. Charudattan, H.C. Kistler, and E. Rosskopf (2001). A molecular characterization of Cercospora species pathogenic to water hyacinth and emendation of C. piaropi Tharp. Mycologia, 93:323-334.

Tessmann, D.J., R. Charudattan, and J. Preston (2008). Variability in aggressiveness, cultural characteristics, cercosporin production and fatty acid profile of Cercospora piaropi, a biocontrol agent of water hyacinth. Plant Pathology, 57:957-966.

Tipping, P.W., T.D. Center, A.J. Sosa, and F.A. Dray (2010). Host specificity assessment and potential impact of Megamelus scutellaris (Hemiptera: Delphacidae) on water hyacinth Eichhornia crassipes (Pontederiales: Pontederiaceae). Biocontrol Science and Technology, 21(1):75-87.

Tipping, P.W., A.J. Sosa, E.N. Pokomy, J.A. Foley, D.C. Schmitz, J.S. Lane, L. Rodgers, L. McCloud, P. Livingston-Way, and G. Nicholas (2014). Release and establishment of Megamelus scutellaris (Hemiptera: Delphacidae) on water hyacinth. Florida Entomologist, 97(2):804-806.

Toft, J.D., C.A. Simenstad, J.R. Cordell, and L.F. Grimaldo (2003). The effects of introduced water hyacinth on habitat structure, invertebrate assemblages, and fish diets. Estuaries, 26(3):746-758.

Turner, P.J., L. Morin, D.G. Williams, and D.J. Kriticos (2010). Interactions between a leafhopper and rust fungus on the invasive plant Asparagus asparagoides in Australia: A case study of two agents being better than one for biological control. Biological Control, 54:322-330.

UNEP (2013). Water hyacinth - Can its aggressive invasion be controlled? http://www.unep.org/.../UNEP_GEAS_APRIL_20 (accessed 12 August 2016).

Van Thielen, R., O. Ajuonu, V. Schade, P. Neuenschwander, A. Adite, and C.J. Lomer (1994). Importation, release, and establishment of Neochetina spp. (Coleoptera: Curculionidae) for the biological control of water hyacinth, Eichhornia crassipes (Lil.: Pontederiaceae), in Benin, West Africa. Entomophaga, 39:179-188.

Venter, N., M.P. Hill, S. Hutchinson, and B. Ripley (2013). Weevil borne microbes contribute as much to the reduction of photosynthesis in water hyacinth as does herbivory. Biological Control, 64:138-142.

Waipara, N.W., G.W. Bourdôt, and G.A. Hurrell (2006). Sclerotinia sclerotiorum shows potential for controlling water lettuce, alligator weed and wandering Jew. New Zealand Plant Protection, 59:23-27.

Waithaka, E. (2013). Impacts of water hyacinth (Eichhornia crassipes) on the fishing communities of Lake Naivasha, Kenya. Journal of Biodiversity Endanger Species, 1:108.

White, T.J., T. Bruns, S. Lee, and J.W. Taylor (1990). Amplification and direct sequencing of fungal ribosomal RNA genes for phylogenetics. In: Innis, M.A., D.H. 
Gelfand, J.J. Sninsky, and T.J. White (Eds.), PCR - Protocols and Applications - A Laboratory Manual. Academic Press, pp. 315-322.

Williams, A.E., R.E. Hecky, and H.C. Duthie (2007). Water hyacinth decline across Lake Victoria - Was it caused by climatic perturbation or biological control? A reply. Aquatic Botany, 87:94-96.

Williamson, M. (1996). Biological invasions. Chapman and Hall, London, UK.

Wilson, J.R., M. Rees, N. Holst, M.B. Thomas, and G. Hill (2001). Water hyacinth population dynamics. In: Julien, M.H., M.P. Hill, T.D. Center, and D. Jianqing (Eds.), Proceedings of the Second Meeting of the Global Working Group for the Biological and Integrated Control of Water Hyacinth, ACIAR Proceedings 102, pp. 96-114.

Wilson, J.R., N. Holst, and M. Rees (2005). Determinants and patterns of population growth in water hyacinth. Aquatic Botany, 81:51-67.

Wright, A.D., and T.D. Center (1984). Predicting population intensity of adult Neochetina eichhorniae (Coleoptera: Curculionidae) from incidence of feeding on leaves of water hyacinth, Eichhornia crassipes. Environmental Entomology, 13:1478-1482.

Wright, A.D., and M.F. Purcell (1995). Eichhornia crassipes [Mart.] Solm-Laubach. In: Groves, R.H., R.C.H. Shepherd, and R.G. Richardson (Eds.), The biology of Australian weeds. R.G. and F.J. Richardson, Melbourne, pp. 111-121.

Wright, A.D., and D.A. Stegeman (1999). The weevil, Neochetina bruchi, could help control water hyacinth in Australia. In: Proceedings of the 9th Australian Weed Conference. Adelaide, South Australia. Council of Australasian Weed Societies, Inc., Bentley Delivery Centre, WA, Australia, pp. 508-510.

Zhang, Y., D. Zhang, and S. Barrett (2010). Genetic uniformity characterises the invasive spread of water hyacinth (Eichhornia crassipes), a clonal aquatic plant. Molecular Ecology, 19:1774-1786. 


\section{Summary}

Water hyacinth (Eichhornia crassipes [Mart.] Solms) remains one of the worst aquatic weeds worldwide. Its presence in Ethiopia was officially reported in Koka Lake and Awash River about 60 years ago. Experiences worldwide indicate that the use of bioagents is the most economical and sustainable control measure for water hyacinth. The mottled water hyacinth weevil (Neochetina eichhorniae Warner) and the chevroned water hyacinth weevil (Neochetina bruchi Hustache) are the most successful bioagents released worldwide. Moreover, several highly virulent pathogens of water hyacinth have been studied and are promising candidates for biocontrol. Despite the presence of highly virulent fungal pathogen and effective weevils against water hyacinth, none of them are utilized to control this aquatic weed in Ethiopia; hence, evaluation of the potential bioagents in water hyacinth management in the country is crucial.

Thus, the overall goal was to assess the problem of water hyacinth and to develop an effective biocontrol strategy for water hyacinth, especially in lakes, dams, irrigation canals and reservoirs in the Rift Valley of Ethiopia, based on the efficient use of fungi and weevils. The specific objectives were:

- To determine the prevalence and agro-ecological distribution of water hyacinth (Chapter 2);

- To identify the fungal pathogens found in association with water hyacinth (Chapters 3 and 4);

- To assess the extent of fungal pathogen controlling potential in decreasing the number and vigour of water hyacinth plant and/or leaf area per plant (Chapter 4);

- To determine adaptability and length of developmental stages of the Neochetina weevils (Chapters 3 and 5);

- To evaluate efficacy of the Neochetina weevils in water hyacinth control (Chapters 5 and 6 );

- To evaluate synergistic effects of the integrated use of Neochetina weevils and potential fungal pathogens for the management of water hyacinth in the Rift Valley of Ethiopia (Chapter 7); and

- To compare and evaluate the application of the protocol and its results in Ethiopia with established results and experiences in the region (Chapter 8).

In order to address the above objectives, a field survey (Chapters 2 and 4) and a number of laboratory and lath house experiments (Chapters 4-7) were conducted. The field survey dealt with water hyacinth agro-ecological distribution and fungal pathogen found in association with water hyacinth. The field experiments examined (i) 


\section{Summary}

pathogenicity and host specificity of the fungal pathogens (ii) adaptability, life table, efficacy and host specificity of the two Neochetina weevils, and (iii) the synergetic effects of integrated use of Neochetina weevils and the fungal pathogen Alternaria alternata as bioagents for management of water hyacinth.

Survey results indicated that the weed is distributed in the Rift Valley water bodies located in low, mid and high altitude. The low altitude water bodies infested by water hyacinth include Lake Abaya, Lake Koka, Koka Dam, and irrigation and drainage structures along Awash River located between Metahara Sugar Estate and Koka Dam. The mid and high altitude infested water bodies include the two lakes located in Alem Tena site (Lake Ellen and Lake Elltoke) and Aba-Samuel Dam, respectively. Univariate analysis as well as principal component analysis indicated that the main factors representing the majority of correlations with water hyacinth coverage are associated with rainfall, $\mathrm{N}$ content, $\mathrm{P}$ content, wave action on the water bodies and depth of the water bodies (Chapter 2). The survey results also identified 25 fungal species found in association with water hyacinth. Both morphological and molecular analyses showed that the fungal isolates belonged to nine genera (Chapter 4). Based on the analysis of data on pathogenicity, host-range, and association with environmental and water factors, Alternaria alternata, A. tenuissima, and Alternaria spp. hold promise as possible biocontrol agents of water hyacinth.

Laboratory study on life cycle and development of Neochetina weevils indicated that the egg hatching period of $N$. bruchi ranged from 4 to 10 days, while $N$. eichhorniae took 8 to 12 days. Larvae of $N$. bruchi took a comparatively shorter period (32-38 days) than $N$. eichhorniae (52-60 days) to complete their development. The intrinsic rate of increase of $N$. bruchi appeared to be 0.06 with a generation time of 74.8 days and a population doubling period of 14.3 days. The intrinsic rate of increase of $N$. eichhorniae was 0.046 accompanied by a generation time of 94.8 days and a doubling period of 18.7 days (Chapter 5). The present study also confirmed that the two weevils produced four generations year ${ }^{-1}$ indicating successful establishment of the two weevils.

Feeding by adult weevils and tunnelling by larvae significantly impacted the vigour and reproduction of water hyacinth plants. Neochetina bruchi and N. eichhorniae affected plants had about 72\% (76\%) and 66\% (58\%) reduction in fresh (and dry) weight, respectively. Moreover, herbivory effect of the weevils at different densities on the reproductive potential of water hyacinth indicated that the lowest number of ramets and leaves was recorded for three pairs of $N$. bruchi released in combination with two pairs of $N$. eichhorniae, which was followed by three pairs of $N$. eichhorniae combined with two as well as three pairs of $N$. bruchi. However, no difference was observed on number of ramets and leaves between combined application of three pairs 
of $N$. bruchi with two and three pairs of $N$. eichhorniae. The study also confirmed that the two weevils are sufficiently host-specific (Chapter 6).

Study on integrated use of Neochetina weevils and an indigenous plant pathogen revealed that the two Neochetina weevils and the fungus A. alternata were together able to reduce the vegetative growth and fresh weight of water hyacinth plants considerably. Water hyacinth plants that received the two weevils augmented with $A$. alternata showed a disease index (DI) of $90 \%$ compared with DI values of $70 \%$ and $60 \%$ recorded in $N$. bruchi augmented with A. alternata or $N$. eichhorniae augmented with $A$. alternata, respectively. Application of both weevils augmented with $A$. alternate showed about $97 \%$ and $85 \%$ reduction in number of new ramets and fresh weight, respectively (Chapter 7).

Based on the findings of this study, the following key management actions are proposed to control water hyacinth in a sustainable way using fungal pathogens and weevils as bioagents:

- Since Aba-Samuel Dam is a major source of water hyacinth introduction into Lake Ellen, Lake Elltoke, Lake Koka, and Koka Dam, a collaborative and integrated biological control programme should be extended to cover the entire Awash River basin (Chapter 2);

- Taking into account the significance of climate for the success of the two weevils, it is advisable to make use of a predictive model (e.g. CLIMEX; climate-matching approach) as part of the pre-release assessment protocol (Chapter 3);

- Among the fungal pathogens, A. alternata and A. tenuissima are recommended as possible biocontrol agents of water hyacinth (Chapter 4);

- Both N. eichhorniae and N. bruchi are recommended to be released together in large scale management programs of water hyacinth (Chapter 5 and Chapter 6) at herbivory loads of the weevils greater than one weevil per plant (Chapter 6);

- Both N. eichhorniae and N. bruchi are sufficiently host specific and, therefore, can be safely released for the management of water hyacinth (Chapter 6); and

- Taking into account the synergy between fungal pathogens and the two weevil species it is advisable to augment the large scale release of the two weevils with fungal pathogens (Chapter 7).

All of the above-mentioned management measures have great potential to establish environmentally-friendly, cost-effective and sustainable biological management strategies against water hyacinth. Implementation of the above recommendations will benefit: 
(i) the riparian community whose life mainly depends on the water bodies affected by water hyacinth;

(ii) agro-processing industries established along the Awash River; and

(iii) hydro-power stations established in the Rift Valley of Ethiopia.

In addition to the Rift Valley water bodies, large scale release of the two weevils is indispensable for Lake Tana and Lower Nile Basin countries (Egypt and Sudan) as well as the riparian communities along the Basin. 


\section{List of publications of the author}

\section{Peer reviewed Journal articles:}

Firehun Y., Struik P.C., Lantinga E.A. and Taye T. 2017. Occurrence and diversity of fungal pathogens associated with water hyacinth and their potential as biocontrol agents in the Rift Valley of Ethiopia. International Journal of Pest Management (published online 11 Jan 2017).

Firehun Y., Struik P.C., Lantinga E.A. and Taye T. 2016. Pre-release evaluation of Neochetina weevils potential for the management of Eichhornia crassipes (Mart.) Solms in the Rift Valley of Ethiopia. Academia Journal of Agricultural Research, 4(7): 394-403.

Firehun Y., Struik P.C., Lantinga E.A. and Taye T. 2015. Adaptability of two weevils (Neochetina bruchi and Neochetina eichhorniae) with potential to control water hyacinth in the Rift Valley of Ethiopia. Crop Protection, 76: 75-82.

Firehun Y., Struik P.C., Lantinga E.A. and Taye T. 2014. Water hyacinth in the Rift Valley water bodies of Ethiopia: Its distribution, socio-economic importance and management. International Journal of Current Agricultural Research, 3(5): 67-75.

Firehun Y., Struik P.C., Lantinga E.A. and Taye T. 2013. Joint use of insects and fungal pathogens in the management of water hyacinth (Eichhornia crassipes): Perspectives for Ethiopia. Journal of Aquatic Plant Management, 51: 109-121.

Firehun Y., Tamado T., Abera T. and Yohannes Z. 2013. Weed interference in the sugarcane (Saccharum officinarum L.) plantations of Ethiopia. Agriculture, Forestry and Fisheries, 2(6): 239-247.

Ayalkebet T., Firehun Y. and Zewdu A. 2012. Increasing the efficiency of knapsack sprayers by modifying a single nozzle sprayer into a low cost multi-nozzle sprayer. Ethiopian Journal of Weed Management, 5: 28-42.

Firehun Y., Tamado T., Abera T. and Yohannes Z. 2012. Competitive ability of sugarcane (Saccharum officinarum L.) cultivars to weed interference in sugarcane plantation of Ethiopia. Crop Protection, 32:138-143.

Yohannes Z., Firehun Y., Teklu B. and Leul M. 2012. Effect of Leifsonia xyli subsp. xyli concentration on yields of four sugarcane varieties in the sugarcane plantations of Ethiopia. Ethiopian Journal of Applied Science and Technology, 3(2): 25-30.

Leul M., Firehun Y. and Yohannes Z. 2011. Effect of planting month and variety on sugarcane borers in Ethiopia. Ethiopian Journal of Agricultural Sciences, 21: 84-94.

Taye T., Rupschus C., Wiesner M., Rezene F., Firehun Y., Ulrichs C., and Buttner C. 2010. Parthenium weed (Parthenium hysterophorus L.) research in Ethiopia: 
Impacts on food production, plant biodiversity and human health. Ethiopian Journal of Agricultural Sciences, 20: 128-150.

Yohannes Z., Mashilla D., Girma T. and Firehun Y. 2010. Importance and status of sugarcane smut (Ustilago scitaminea) in the Ethiopian sugar estates. Ethiopian Journal of Agricultural Sciences, 20: 35-46.

Dula A., Taye T. and Firehun Y. 2008. Efficacy of integrated water hyacinth (Eichhornia crassipes [Mart.] Solms) management strategies at Wonji-Shoa sugar factory. Ethiopian Journal of Weed Management, 2: 45-58.

Mulisa U., Taye T. and Firehun Y. 2008. Impact of Parthenium hysterophorus L. on herbaceous plant diversity in rangelands of Fentale district in the Central Rift Valley of Ethiopia. Ethiopian Journal of Weed Management, 2: 13-29.

Firehun Y., Yohannes Z. and Leul M. 2008. Study on weed composition and flora shift in Finchaa sugarcane plantation. Ethiopian Journal of Weed Management, 2:31-43.

Firehun Y., Abera T., Tariku T. and Taye T. 2007. Distribution, impact and management of water hyacinth at Wonji-Shoa sugar factory. Ethiopian Journal of Weed Management, 1: 41-52.

Firehun Y. and Tamado T. 2007. Qualitative and quantitative assessment of weeds in the sugarcane plantations of Wonji-Shoa and Metahara. Ethiopian Journal of Weed Management, 1: 1-14.

Firehun Y. and Tamado T. 2006. Weed flora in the Rift Valley sugarcane plantations of Ethiopia as influenced by soil types and agronomic practices. Weed Biology and Management, 6: 139-150.

\section{Articles in Conference/ Symposium Proceedings:}

Firehun Y. 2014. Cotton production and value addition investment opportunities in Mozambique: Nhamatanda and Grudja Projects. International Conference on Cotton and Textile Value Chain, 22-23 May 2014, Maputo, Mozambique.

Yohannes Z., Mashilla D., Girma T. and Firehun Y. 2013. Study on cultural and pathogenic variability of Ustilago scitaminea isolates in the sugarcane plantations of Ethiopia. Proceedings of Ethiopian Sugar Industry Biennial Conference, 2: 111-120.

Yohannes Z., Firehun Y., Mashilla D. and Girma T. 2013. Effect of rate and soaking-time of Propiconazole and Triadimefon fungicides against sugarcane smut. Proceedings of Ethiopian Sugar Industry Biennial Conference, 2: 121-129.

Firehun Y., Abera T. and Yohannes Z. 2013. Quarantine activities in sugarcane variety exchange: Challenges and future directions in Ethiopia. Proceedings of Ethiopian Sugar Industry Biennial Conference, 2: 141-149. 
Firehun Y. and Ambachew D. 2012. Cane sugar productivity potential in Ethiopia: The role and direction of research. International Conference on Sustainable Development through Science and Technology, 6-8 September 2012, Adama, Ethiopia.

Shimelis K., Ambachew D. and Firehun Y. 2011. Trends of sugar industry development in Ethiopia: Challenges and prospects. International Conference on the State of Science and Technology in Ethiopia, 28-30 November, 2011, Addis Ababa, Ethiopia.

Firehun Y. 2009. Evaluation of some selective herbicides against weeds in the sugarcane plantations of Ethiopia: Verification trial. Proceedings of Ethiopian Sugar Industry Biennial Conference, 1: 45-60.

Firehun Y., Leul M. and Yohannes Z. 2009. Weed competition in the sugarcane plantations of Ethiopia: Influence of variety and duration of competition. Proceedings of Ethiopian Sugar Industry Biennial Conference, 1: 69-80.

Firehun Y. and Yohannes Z. 2009. Evaluation of some herbicides against water hyacinth (Eichhornia crassipes [Mart.] Solms) at Wonji-Shoa. Proceedings of Ethiopian Sugar Industry Biennial Conference, 1: 61-68.

Firehun Y., Yohannes Z. and Leul M. 2009. Evaluation of some selective herbicides against weeds at tendaho and Kesem sugar project: Verification trial. Proceedings of Ethiopian Sugar Industry Biennial Conference, 1: 81-92.

Leul M., Tadele T., Yoseph A. and Firehun Y. 2009. Biology of Sesamia calamistis Hampson (Lepidoptera: Noctuidae) at Metahara. Proceedings of Ethiopian Sugar Industry Biennial Conference, 1: 35-44.

Leul M., Tadele T., Yoseph A. and Firehun Y. 2009. Sugarcane stalk borer species composition and their impact in the sugarcane plantations of Ethiopia. Proceedings of Ethiopian Sugar Industry Biennial Conference, 1: 22-34.

Firehun Y. 2009. Evaluation of Aterbutex 50 SC against weeds at Tendaho sugar project: Pre-verification trial. Proceedings of Ethiopian Sugar Industry Biennial Conference, 1: 61-68.

Firehun Y., Yohannes Z. and Teklu B. 2009. Reactions of some sugarcane varieties to red rot (Glomerella tucumenensis [Speg] Arx \& Muller) in Finchaa Valley. Proceedings of Ethiopian Sugar Industry Biennial Conference, 1: 166-170.

Firehun Y. 2008. Integrated water hyacinth management strategy: Successes and challenges. In: Abera T. (ed.), Proceedings of Conferences on Cultural Practices of Wonji-Shoa Sugarcane Plantation, Wonji-Shoa, Ethiopia, pp. 15-27.

Firehun Y., Kederu K., Wondimeagen M. and Ayalew Y. 2008. Weed management and its limitation in the sugarcane plantation of Wonji-Shoa. In: Abera T. (ed.), Proceedings of Conferences on Cultural Practices of Wonji-Shoa Sugarcane Plantation, Wonji-Shoa, Ethiopia, pp. 38-47. 


\section{Books, technical papers and book chapters:}

Amabchew D., Firehun Y., Solomon A., Tariku G. and Zeleke G. 2014. Sugarcane production guideline. Kwale International Sugar Company Limited, Nairobi, Kenya. $104 \mathrm{p}$.

Ambachew D., Firehun Y. and G. Tariku. 2013. Seed cane production guideline. Booklet No. 1, Kwale International Sugar Company Limited, Nairobi, Kenya. 29 p.

Ambachew D., Firehun Y. and G. Tariku. 2013. Sugarcane growth measurement guideline. Booklet No. 2, Kwale International Sugar Company Limited, Nairobi, Kenya. 23 p.

Ambachew D., Firehun Y. and Chebosi P. 2013. Kwale Outgrowers Sugarcane Production Manual, Booklet No. 3, Kwale International Sugar Company Limited, Nairobi, Kenya. 45 p.

Firehun Y., Abera T., Yohannes Z. and Leul M. 2009. Handbook for sugarcane pest management in Ethiopia. Apple Printing Press, Addis Ababa, Ethiopia. 60 p.

Abera T., Firehun Y. and Solomon B. 2009. Review of sugarcane protection research in Ethiopia. In: Abraham T. (ed.) Increasing crop production through improved plant protection: Vol. 2. Plant Protection Society of Ethiopia, Addis Ababa, Ethiopia. pp. 409-447.

Taye T., Rezene F., Firehun Y., Derje T. and Tamado T. 2009. Review invasive weed research in Ethiopia. In: Abraham T. (ed.) Increasing crop production through improved plant protection: Vol. 2. Plant Protection Society of Ethiopia, Addis Ababa, Ethiopia. pp. 381-407. 


\section{Acknowledgements}

When I think about this thesis, it takes me to the date when I met my supervisors for the first time. Prof. Paul Struik, I can't forget your hospitability, timely responses and our discussions on the project that has come now to reality. I thank you for your confidence in me and the opportunity you gave me. Prof. Paul Struik, I have got a good lesson from you both in my professional and personal life. I thank you for all. Dr. Egbert Lantinga, I thank you for trusting in my capacity and paving my way to Wageningen University and Research. I appreciate your guidance and comments especially at the final stage of the thesis, which had a paramount importance to the quality of this work. Dr. Taye Tessema, you are my mentor, I thank you for helping me to enter into the world of biocontrol science. I learned good lessons in our discussions. All in all, I would like to extend my deepest gratitude and indebtedness to the three supervisors for the efficient supervision and consistent encouragement. This thesis could not have taken its present shape and content without your immense input by providing the necessary materials, constructive comments, suggestions, unfailing guidance and encouragement.

Moreover, I believe this thesis is the outcome of collective efforts and I would like to extend my sincere acknowledgement to all who have been with me in this long journey. Grateful acknowledgement is due to Ambachew Dametie, the former Deputy Director General of the Ethiopian Sugar Corporation (ESC), for his active involvement in all matters from proposal inception till final write-up of this thesis. I am deeply indebted to Teklu Baissa, Director of Plant Health and Regulatory Directorate of Ethiopia, Tesfaye Berhanu, Abera Tafesse, Zewdu Negatie, Abiy Fantaye, Yohannes Zekarias, Esayas Tena (Staffs of ESC), Dr. Tamado Tana (Haramaya University) and Gizachew Legesse (Ethiopian Institute of Agricultural Research, Melkassa) for the useful comments on various aspects of the work, technical, administrative and moral support.

I also want to thank Dine Volker for assisting me in handling the morphological characterization of the fungal pathogens, Oscar de Vos for facilitating importation of my samples from Ethiopia and for guiding my work in the Molecular Biology Laboratory (ML-II lab) as well as the greenhouse experiment at UNIFARM. I also like to thank Dr. Meindert de Jong and Dr. Barend de Voogd for the productive and fruitful inputs with regard to formulation development and for your technical support in my greenhouse experiment. I am also deeply grateful to all the staff members of the Ambo Plant Protection Research Center (APPRC) and the Ethiopian Sugar Corporation 
Research and Training (ESCRT) who helped me to carry out all the experiments and measurements. At APPRC special thanks go to Tesfaye Hailu, Desalign Gela and other employees for all the time invested in my trials. At ESCRT, my special thanks go to Amrote Tekle, Asmamaw Teshome, Abiy Nigesu, Dawit Balcha, Teshome Yami, Kassahun Melka, John Wotere, and Bezuneh Yeshitela for helping me in trial organization, assessments, working with me hand-in-hand, facilitating and availing the necessary resources to my research and, most importantly, for your understanding of my views in due course of the experiment. Furthermore, many thanks to all other employees who have been involved in maintaining the experiment, acclimatizing the water hyacinth plants and assessing the experiments.

I gratefully acknowledge the Ethiopian Institute of Agricultural Research (EIAR), the National Agricultural Research Institute (NAARI) and Kawanda Agricultural Research Institute (KAARI) of the National Agricultural Research Organization (NARO), Uganda, for the preparation of practical training and arrangement of field visits to water hyacinth sites in Lake Victoria. I am very thankful to the GoE-UNEP/GEF RBIPMA Project in Uganda for coordinating the study tour. I greatly acknowledge Dr. Richard Molo, Dr. Caroline Nankinga, Aropet Stella and Nampeera Florence, who are the members of the biocontrol unit, NARO Laboratories, Kampala, Uganda, for their hospitality and endeavor to pass their knowledge and experience.

I have had a great time in Wageningen and I benefited from many friends. I would like to thank Habtamu, Selam, Seleshi, Yodit, Victoria, Uma, Jose, and Bas, for great time, lunch, coffee time, dinners, and entertaining discussions. I am indebted to Wampie, the secretary of the FSE group in facilitating many administrative things, including the final presentation of this thesis. The presence of all of you here in Wageningen made my life much easier and better.

The research was financed by the Ethiopian Institute of Agricultural Research GoEUNEP/GEF RBIPMA Project in Ethiopia, ESC and Wageningen University and Research (Farming Systems Ecology Group and Crop Systems Analysis Group) to which I am very grateful.

Finally, I would like to thank my beloved family: Yirefu, Tsehaye, Belaynesh, Tesfu, Kibebe, Emama, Meron, Christian, and Emebet. So many things have happened during this time. Thank you for your patience and unconditional support to my work, life and soul. This was not possible without all of you.

Firehun Yirefu Gebregiorgis Wageningen, December 2016 


\section{Curriculum vitae}

Firehun Yirefu Gebregiorgis was born in Addis Ababa, Ethiopia, on $5^{\text {th }}$ of June 1978. He attended primary and secondary school at 'Abiyot Kirse' Senior Secondary School, Addis Ababa, Ethiopia. Upon completion of his high school education, he joined the former Alemaya University (currently Haromaya University) in 1996 and graduated with a Bachelor of Science degree in Plant Sciences in 2000. In 2001, he was employed by the Ethiopian Sugar Industry Support Center Share Company in the Research and Training Division as a crop protection researcher and served for two years. Based on the dedication and excellent performance he exhibited, the employer offered him a scholarship to pursue his Master of Science studies in Crop protection at Alemaya University in 2002, from which he graduated in 2004. From 2004 to 2009, he worked as a researcher in different capacities (Researcher I to Researcher III). As of 2009, he worked as head of the Crop Protection Research Program and Manager of Sugar Research and Training Division. His roles as a researcher and research manager included planning, organizing and directing overall activities of the research and extension unit; developing and implementing research projects; and producing guidelines, working manuals and teaching materials. In July 2011, he started a 'sandwich' PhD Programme within the Farming Systems Ecology Group of Wageningen University under the supervision of Prof. dr. Paul Struik, Dr. Egbert Lantinga, and Dr. Taye Tessema. The main target of his $\mathrm{PhD}$ research was to develop an effective integrated water hyacinth control strategy through the use of biological agents especially in lakes, irrigation canals and reservoirs in the Rift Valley of Ethiopia. This research resulted in this thesis. At present, he is working for a private company in Kenya (Pabari Investment Limited) as technical team coordinator, and he is in charge of coordinating the agribusiness teams of experts undertaking feasibility studies, operation technical audits and operations advisory service. 


\section{PE\&RC Training and Education Statement}

With the training and education activities listed below the PhD candidate has complied with the requirements set by the C.T. de Wit Graduate School for Production Ecology and Resource Conservation (PE\&RC) which comprises of a minimum total of 32 ECTS ( $=22$ weeks of activities)

\section{Review of literature (6 ECTS)}

- Joint use of insects and fungal pathogens in the

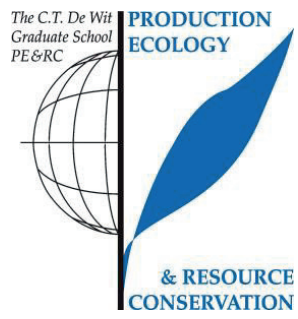
management of water hyacinth (Eichhornia crassipes): perspectives for Ethiopia

\section{Writing of project proposal (4.5 ECTS)}

- Management of water hyacinth (Eichhornia crassipes) using bioagents in the Rift Valley of Ethiopia

\section{Post-graduate courses (5.7 ECTS)}

- Integrated pest management and food safety; WUR (2010)

\section{Laboratory training and working visits (3.6 ECTS)}

- Weevils mass rearing techniques; Namuloge Agricultural and Animal Production Research Institute, Uganda (2011)

- Fungal pathogens mass production techniques; Ambo Plant Protection Research Institute, Ethiopia (2011)

\section{Invited review of (unpublished) journal manuscript (2 ECTS)}

- $\quad$ Ethiopian Journal of Applied Science and Technology: Cotton-weed competition (2014)

- International Journal of Pest Management: Beyond biocontrol: water hyacinth opportunities and challenges (2015)

\section{Deficiency, refresh, brush-up courses (3 ECTS)}

- Weed biological control; Ethiopian Institute of Agricultural Research (2013)

- Molecular characterization of fungi; WUR (2011)

\section{Competence strengthening / skills courses (4.5 ECTS)}

- Project planning, implementation, monitoring and evaluation; Ethiopian Management Institute (2013)

PE\&RC Annual meetings, seminars and the PE\&RC weekend (0.3 ECTS)

- PE\&RC Day (2011)

\section{Discussion groups / local seminars / other scientific meetings (7.2 ECTS)}

- Professional society meeting; Ethiopia (2011-2016)

- $\quad$ Research review meeting; Ethiopia (2011-2016)

- $\quad 2^{\text {nd }}$ Ethiopian sugar industry biennial conference; Adama, Ethiopia (2012)

\section{International symposia, workshops and conferences (5.4 ECTS)}

- International conference on the state of science and technology in Ethiopia; Addis Ababa, Ethiopia (2011)

- International conference on sustainable development through science and technology; Adama, Ethiopia (2012)

- $\quad$ Conference on cotton and textile value chain; Maputo, Mozambique (2014)

\section{Supervision of MSc students (3 ECTS)}

- Distribution and impacts of Parthenium hysterophorus L. on herbaceous plant diversity of Fentale District, Central Rift Valley of Ethiopia

- Increasing the efficiency of Knapsack herbicide sprayers

- Weeds and their response to ametryn-atrazine herbicide at Wonji-Shoa 